O jornal na sociedade da informação:

como a 'Folha', o 'Globo' e o 'Estado' respondem às inovações tecnológicas, à queda de leitura e à concorrência com novos meios

Dissertação de Mestrado

São Paulo 


\section{O jornal na sociedade da informação: como a Folha, o Globo e o Estado respondem às inovações tecnológicas, à queda de leitura e à concorrência com novos meios}

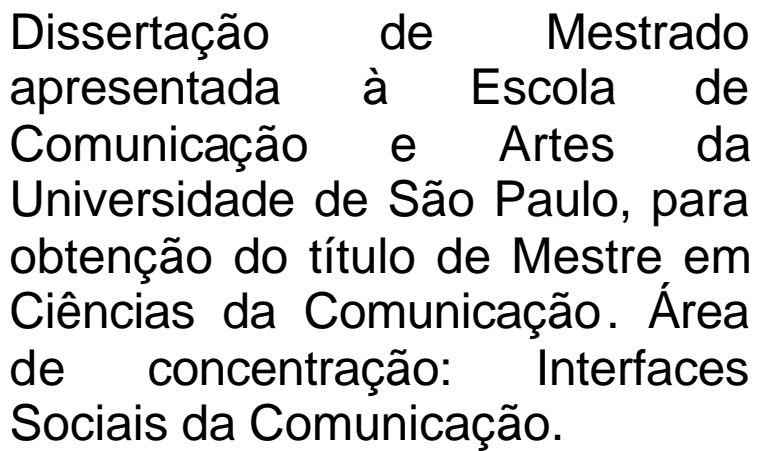

Orientadora: Profa. Dra. Elizabeth Nicolau Saad Correa

São Paulo

2007 


\section{Autorizo:}

[ ] divulgação do texto completo em bases de dados especializadas.

[ ] reprodução total ou parcial, por processos

fotocopiadores, exclusivamente para fins acadêmicos e científicos.

Assinatura:

Data: 
Nome do Autor: Lourival Sant'Anna

Título da Dissertação: 0 jornal na sociedade da informação: como a Folha, o Globo e o Estado respondem às inovações tecnológicas, à queda de leitura e à concorrência com novos meios.

Presidente da Banca: Prof. Dr.

Banca Examinadora:

Prof. Dr. Instituição:

Prof. Dr. Instituição:

Prof. Dr. Instituição:

Prof. Dr. Instituição:

Prof. Dr. Instituição:

Aprovada em: 


\section{Agradecimentos}

À minha orientadora, Profa. Dra. Elizabeth Nicolau Saad Correa.

Aos participantes da banca de qualificação: Prof. Dr. Gilson Schwartz e Prof.

Dr. Dílson Gabriel dos Santos.

Aos meus entrevistados: Sandro Vaia, Otavio Frias Filho, Rodolfo Fernandes, Ramón Salaverría e Nicholas Negroponte.

Aos meus colegas e amigos Eleno Mendonça, Roberto Gazzi, Paula Puliti e Renato Cruz.

À minha mulher e aos meus filhos. 
SANT'ANNA, Lourival. O jornal na sociedade da informação: como a Folha, o Globo e o Estado respondem às inovações tecnológicas, à queda de leitura e à concorrência com novos meios. São Paulo, 2007. 128 f.

Dissertação (Mestrado) - Escola de Comunicação e Artes, Universidade de São Paulo.

RESUMO: Estuda o impacto da concorrência da internet, das TVs a cabo, do rádio e das revistas semanais sobre os jornais diários, num contexto de mudança dos hábitos de leitura. Analisa como os três principais jornais brasileiros respondem a esses desafios, sobre o pano de fundo da inovação tecnológica. Dados quantitativos indicam queda acentuada da circulação dos jornais na última década, apesar de uma recuperação em 2005. Os números também mostram uma diminuição contínua no tempo dedicado à leitura de jornais. Pesquisa qualitativa mostra que o público-alvo identifica os jornais com credibilidade, contextualização e análise, mas se ressente da falta de estímulos para a leitura, de seu aspecto pesado e sisudo. A revisão da bibliografia aponta que a indústria do jornal sofre pressões também no seu modelo de gestão. Empresas familiares dão lugar a sociedades de capital aberto, cujos acionistas pressionam por lucros. Executivos vindos de outras áreas implementam formas de gestão que priorizam critérios contábeis em detrimento de "caprichos de jornalistas", como cadernos pouco rentáveis e coberturas dispendiosas. Diante disso, autores americanos e europeus procuram estabelecer correlações entre fatores intangíveis, como credibilidade e influência, e resultados associados à lucratividade, como penetração e circulação. Especialistas entrevistados prevêem uma aceleração da conversão, já em curso, dos jornais impressos em meios digitais. Os diretores de redação dos três jornais que são objeto do estudo - Folha, Globo e Estado - asseguram, em entrevistas, que os jornais impressos continuam sendo negócios rentáveis e ocupando lugar de destaque entre os meios de comunicação. Eles reconhecem que os jornais não voltarão aos picos de circulação dos anos 90 , produzidos pela política de brindes conhecidos como "anabolizantes". Mas defendem a função dos jornais como veiculadores de notícias contextualizadas e com o suporte de análises. A ênfase deve deslocar-se do estritamente factual para 0 analítico $e$ interpretativo. Conclui-se que os três grandes jornais brasileiros reagem ao 
aumento da concorrência procurando realçar os atributos que os diferenciam dos outros meios, como a credibilidade e a capacidade de contextualização e interpretação da notícia, além da qualidade da narrativa. Entretanto, a mudança do suporte de papel para o online deve ter conseqüências sobre o modo de fazer jornal e sobre a relação entre o jornal e a publicidade, por causa sobretudo da demanda por interatividade dos usuários de internet e da exploração do hipertexto pelos anunciantes. A grande questão é se os jornais resistirão a essas demandas, correndo o risco de se tornarem menos relevantes no ambiente digital; ou se cederão, colocando em risco valores do jornalismo.

Palavras-chave: Jornalismo. Jornal. Imprensa. Mídia. 
SANT'ANNA, Lourival. The newspaper in the information society: how Folha, Globo and Estado respond to technological innovations, readership decline and new media's competition. São Paulo, 2007. 128 I.

Dissertation (Master in Communication Sciences) - Escola de Comunicação e Artes, Universidade de São Paulo.

ABSTRACT: It studies the impact of competition by internet, cable TV, radio and weekly magazines on daily newspapers, within a context of change in reading habits. It analyzes how the three main Brazilian newspapers respond to those challenges, on the background of technological innovation. Quantitative data suggest a steep decline in newspapers' circulation in the last decade, despite a reaction in 2005. Figures also show a continuous reduction of time dedicated to the reading of newspapers. A qualitative poll shows that the target audience associates newspapers with credibility, context and analysis, but resents the lack of stimulation to read, and its heavy and stern look. Literature review points out that the newspaper industry managing model is also under pressure. Family-owned companies are replaced by open capital ones, whose shareholders put pressure for profits. Executives from other areas implement managing tools which put accountancy criteria before "journalists' caprices", such as little profitable sections and expensive coverages. In the face of that, American and European authors try to establish correlations between intangible factors, such as credibility and influence, and returns associated to profitability, such as penetration and circulation. Experts interviewed foressee a speed-up of the conversion, already in place, of print newspapers into digital media. The Editors-in-chief of the three newspapers studied - Folha, Globo and Estadoassure, in interviews, that print newspapers remain profitable businesses, well placed among the media. They admit that the papers won't repeat the circulation peaks of the nineties, brought in by the gifts' policies known as "anabolic steroids". But they argue in favour of the newspapers' role as suppliers of analysis supported context-rich news. The emphasis should move from hard news to analysis and interpretation. The conclusion is that the major Brazilian newspapers respond to the increasing competition by trying to highlight the features which distinguish them from the other media, such as credibility and the ability to add context and interpretation to the news, along 
with narrative quality. However, the change from print to online should impact on the making of a newspaper and on the relationship between the medium and advertising, above all due to the demand for interactivity by internet users and the exploring of hypertext by advertisers. The big question is whether the newspapers will resist those demands, running the risk of becoming less relevant in the digital environment; or whether they will compromise, putting the values of journalism at risk.

Keywords: Journalism. Newspaper. Press. Media. 


\section{ÍNDICE DE TABELAS}

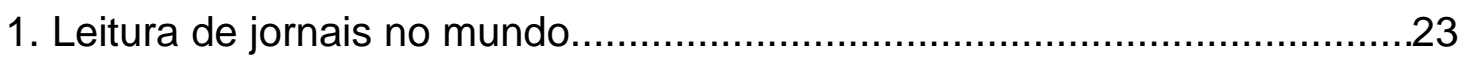

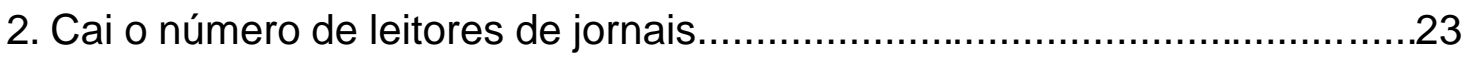

3. Tempo de leitura dos jornais (minutos por dia)..........................................24

4. Percepção do consumo de outras mídias com o início do uso da web........31

5. Circulação dos principais jornais brasileiros...............................................

6. Vantagens e desvantagens de cada meio de comunicação..........................68

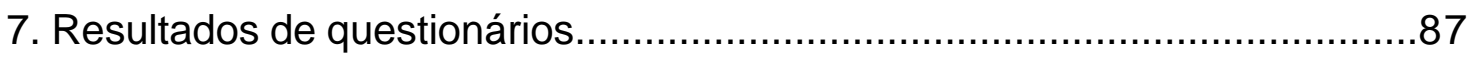




\section{ÍNDICE DE GRÁFICOS}

1. Diminui o número de exemplares por mil habitantes adultos.....................22

2. Circulação média diária dos jornais.........................................................25

3. Variação da circulação média diária dos jornais.........................................25

4. Crescimento do PIB x Circulação dos jornais...........................................26

5..Cai a circulação de revistas no Brasil......................................................27

6. Cresce o número de jornais diários no Brasil.............................................28

7. Cresce o número de revistas no Brasil..................................................29

8. Faturamento bruto anual de todos os jornais do Brasil..............................32

9. Faturamento bruto anual dos meios de comunicação de todo o Brasil.........33

10. Evolução dos índices de leitura da "Revista A"........................................55 
SUMÁRIO

ÍNDICE DE TABELAS

ÍNDICE DE GRÁFICOS

RESUMO

ABSTRACT

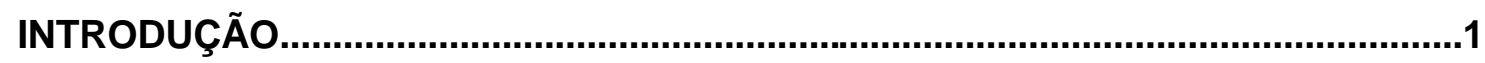

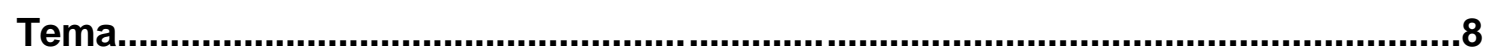

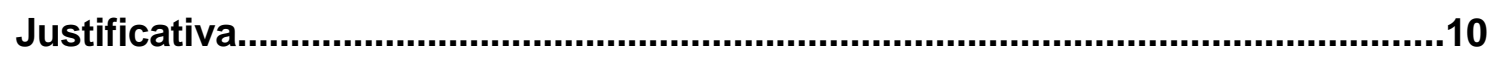

Quadro teórico de referência...........................................................................11

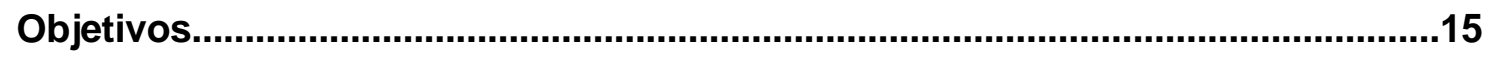

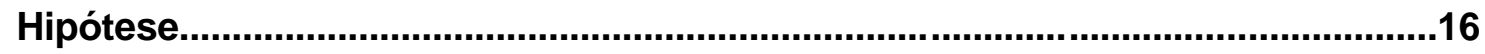

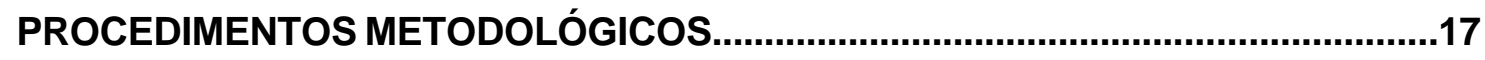

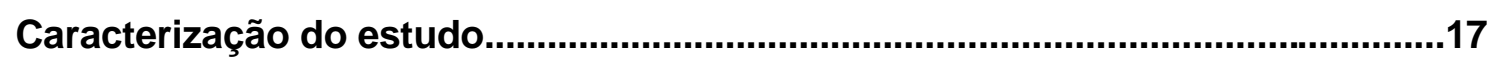

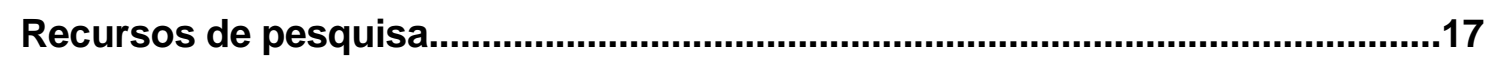

Metodologia de análise dos dados coletados......................................................19

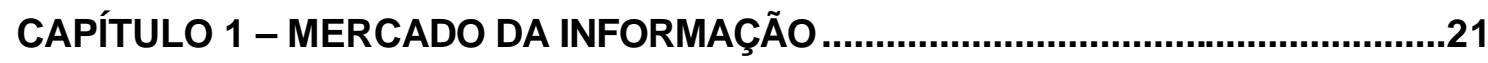

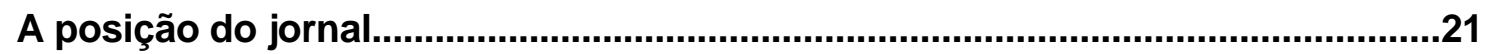

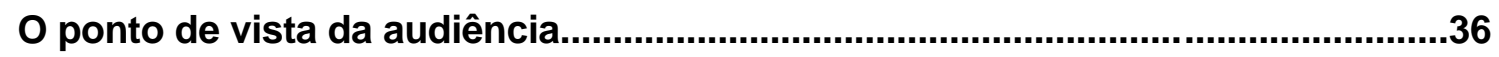

Índice de qualidade editorial.........................................................................54

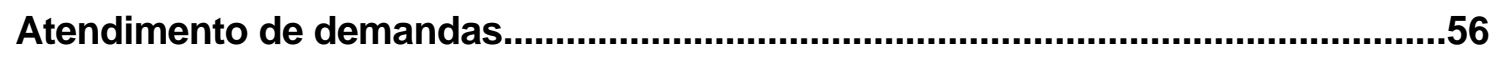

CAPÍTULO 2 - CONCEITOS E TENDÊNCIAS.......................................................58

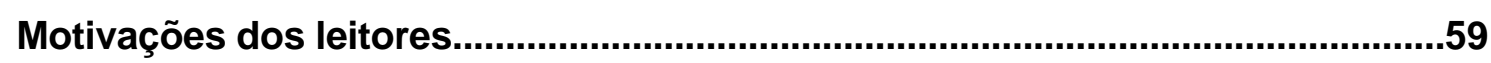

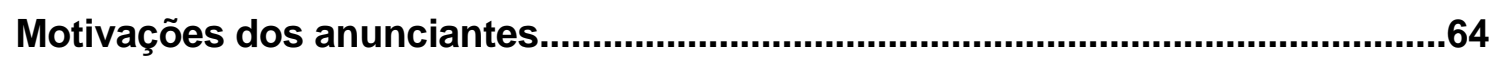

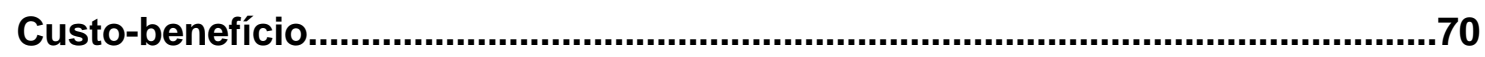

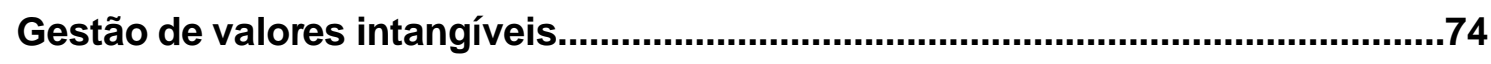

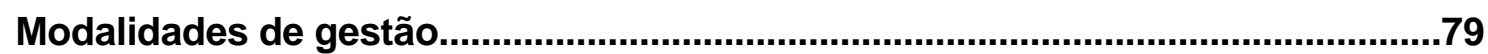

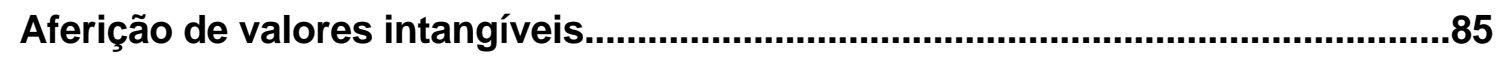

Mudança de paradigma.........................................................................................90

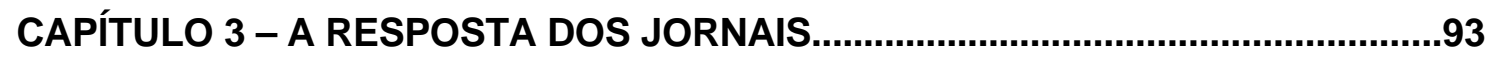

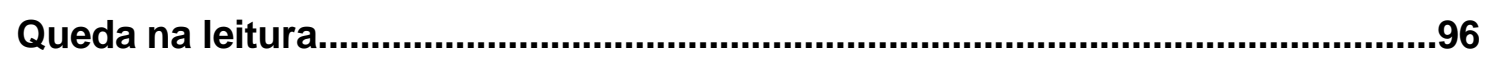

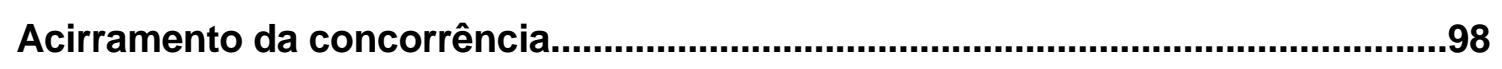

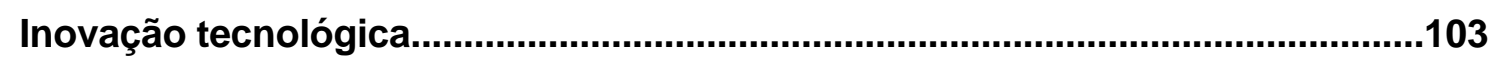

CAPÍTULO 4 - A VISÃO DE ESPECIALISTAS..................................................110

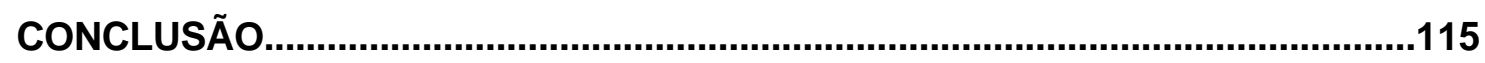

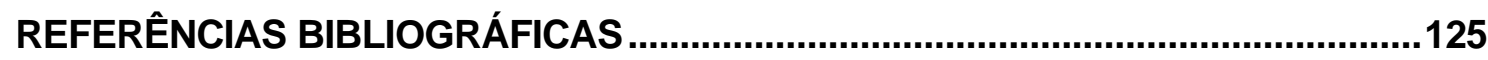

BIBLIOGRAFIA CONSULTADA........................................................................128 
ANEXOS - ENTREVISTAS

Sandro Vaia

Otavio Frias Filho

Rodolfo Fernandes

Ramón Salaverría

Nicholas Negroponte 


\section{PRÓLOGO}

Este trabalho é uma tentativa de avaliar o impacto da concorrência dos outros meios, da mudança nos hábitos de leitura e da inovação tecnológica sobre o jornal, e como os três principais jornais do país respondem a esses desafios. $O$ jornal é encarado, aqui, como uma indústria, um negócio, um produto. O foco, se quisermos, está colocado sobre a forma, não sobre o conteúdo. Não se propõe aqui discutir questões vinculadas à praxis jornalística. Não se faz uma crítica da mensagem. Aceita-se o conteúdo como um dado, da mesma maneira como se assume que o modo de coexistência dos meios de comunicação está relacionado com os seus respectivos suportes tecnológicos.

Este não é um estudo de caráter epistemológico. Sua abordagem é, se quisermos, funcionalista. Conceitos como "influência", "prestígio" e "credibilidade", interessam, aqui, não pelas discussões que podem suscitar acerca de seu significado, mas simplesmente como qualidades que o públicoalvo dos meios de comunicação identifica ou não identifica nesses meios - e as conseqüências disso para o jornal.

O estudioso das Ciências da Comunicação certamente observará a influência das escolas americanas neste estudo. Embora autores europeus também sejam citados, predomina a abordagem funcionalista americana. Não se encontrarão, aqui, as análises de conteúdo acentuadamente inspiradas em escolas européias, como a de Frankfurt, ou, mais recentemente, dos Estudos Culturais - campos de pesquisa das Ciências da Comunicação que se têm mostrado férteis o bastante no Brasil. 


\title{
O jornal na sociedade da informação: como a Folha, o Globo e o Estado respondem às inovações tecnológicas, à queda de leitura e à concorrência com novos meios
}

\begin{abstract}
Dissertação de Mestrado apresentada à Escola de Comunicação e Artes da Universidade de São Paulo, para obtenção do título de Mestre em Ciências da Comunicação. Área de concentração: Interfaces Sociais da Comunicação.
\end{abstract}

Orientadora: Profa. Dra. Elizabeth Nicolau Saad Correa

São Paulo

2007 


\section{Autorizo:}

[ ] divulgação do texto completo em bases de dados especializadas.

[ ] reprodução total ou parcial, por processos

fotocopiadores, exclusivamente para fins acadêmicos e científicos.

Assinatura:

Data: 
Nome do Autor: Lourival Sant'Anna

Título da Dissertação: 0 jornal na sociedade da informação: como a

Folha, o Globo e o Estado respondem às inovações tecnológicas, à queda de leitura e à concorrência com novos meios.

Presidente da Banca: Prof. Dr.

Banca Examinadora:

Prof. Dr. Instituição:

Prof. Dr. Instituição:

Prof. Dr. Instituição:

Prof. Dr. Instituição:

Prof. Dr. Instituição:

Aprovada em: 


\section{Agradecimentos}

À minha orientadora, Profa. Dra. Elizabeth Nicolau Saad Correa.

Aos participantes da banca de qualificação: Prof. Dr. Gilson Schwartz e Prof.

Dr. Dílson Gabriel dos Santos.

Aos meus entrevistados: Sandro Vaia, Otavio Frias Filho, Rodolfo Fernandes, Ramón Salaverría e Nicholas Negroponte.

Aos meus colegas e amigos Eleno Mendonça, Roberto Gazzi, Paula Puliti e Renato Cruz.

À minha mulher e aos meus filhos. 
SANT'ANNA, Lourival. O jornal na sociedade da informação: como a Folha, o Globo e o Estado respondem às inovações tecnológicas, à queda de leitura e à concorrência com novos meios. São Paulo, 2007. 128 f.

Dissertação (Mestrado) - Escola de Comunicação e Artes, Universidade de São Paulo.

RESUMO: Estuda o impacto da concorrência da internet, das TVs a cabo, do rádio e das revistas semanais sobre os jornais diários, num contexto de mudança dos hábitos de leitura. Analisa como os três principais jornais brasileiros respondem a esses desafios, sobre o pano de fundo da inovação tecnológica. Dados quantitativos indicam queda acentuada da circulação dos jornais na última década, apesar de uma recuperação em 2005. Os números também mostram uma diminuição contínua no tempo dedicado à leitura de jornais. Pesquisa qualitativa mostra que o público-alvo identifica os jornais com credibilidade, contextualização e análise, mas se ressente da falta de estímulos para a leitura, de seu aspecto pesado e sisudo. A revisão da bibliografia aponta que a indústria do jornal sofre pressões também no seu modelo de gestão. Empresas familiares dão lugar a sociedades de capital aberto, cujos acionistas pressionam por lucros. Executivos vindos de outras áreas implementam formas de gestão que priorizam critérios contábeis em detrimento de "caprichos de jornalistas", como cadernos pouco rentáveis e coberturas dispendiosas. Diante disso, autores americanos e europeus procuram estabelecer correlações entre fatores intangíveis, como credibilidade e influência, e resultados associados à lucratividade, como penetração e circulação. Especialistas entrevistados prevêem uma aceleração da conversão, já em curso, dos jornais impressos em meios digitais. Os diretores de redação dos três jornais que são objeto do estudo - Folha, Globo e Estado - asseguram, em entrevistas, que os jornais impressos continuam sendo negócios rentáveis e ocupando lugar de destaque entre os meios de comunicação. Eles reconhecem que os jornais não voltarão aos picos de circulação dos anos 90 , produzidos pela política de brindes conhecidos como "anabolizantes". Mas defendem a função dos jornais como veiculadores de notícias contextualizadas e com o suporte de análises. A ênfase deve deslocar-se do estritamente factual para $o$ analítico $e$ 
interpretativo. Conclui-se que os três grandes jornais brasileiros reagem ao aumento da concorrência procurando realçar os atributos que os diferenciam dos outros meios, como a credibilidade e a capacidade de contextualização e interpretação da notícia, além da qualidade da narrativa. Entretanto, a mudança do suporte de papel para o online deve ter conseqüências sobre o modo de fazer jornal e sobre a relação entre o jornal e a publicidade, por causa sobretudo da demanda por interatividade dos usuários de internet e da exploração do hipertexto pelos anunciantes. A grande questão é se os jornais resistirão a essas demandas, correndo o risco de se tornarem menos relevantes no ambiente digital; ou se cederão, colocando em risco valores do jornalismo.

Palavras-chave: Jornalismo. Jornal. Imprensa. Mídia. 
SANT'ANNA, Lourival. The newspaper in the information society: how Folha, Globo and Estado respond to technological innovations, readership decline and new media's competition. São Paulo, 2007. 128 I.

Dissertation (Master in Communication Sciences) - Escola de Comunicação e Artes, Universidade de São Paulo.

ABSTRACT: It studies the impact of competition by internet, cable TV, radio and weekly magazines on daily newspapers, within a context of change in reading habits. It analyzes how the three main Brazilian newspapers respond to those challenges, on the background of technological innovation. Quantitative data suggest a steep decline in newspapers' circulation in the last decade, despite a reaction in 2005. Figures also show a continuous reduction of time dedicated to the reading of newspapers. A qualitative poll shows that the target audience associates newspapers with credibility, context and analysis, but resents the lack of stimulation to read, and its heavy and stern look. Literature review points out that the newspaper industry managing model is also under pressure. Family-owned companies are replaced by open capital ones, whose shareholders put pressure for profits. Executives from other areas implement managing tools which put accountancy criteria before "journalists' caprices", such as little profitable sections and expensive coverages. In the face of that, American and European authors try to establish correlations between intangible factors, such as credibility and influence, and returns associated to profitability, such as penetration and circulation. Experts interviewed foressee a speed-up of the conversion, already in place, of print newspapers into digital media. The Editors-in-chief of the three newspapers studied - Folha, Globo and Estadoassure, in interviews, that print newspapers remain profitable businesses, well placed among the media. They admit that the papers won't repeat the circulation peaks of the nineties, brought in by the gifts' policies known as "anabolic steroids". But they argue in favour of the newspapers' role as suppliers of analysis supported context-rich news. The emphasis should move from hard news to analysis and interpretation. The conclusion is that the major Brazilian newspapers respond to the increasing competition by trying to highlight the features which distinguish them from the other media, such as credibility and the ability to add context and interpretation to the news, along 
with narrative quality. However, the change from print to online should impact on the making of a newspaper and on the relationship between the medium and advertising, above all due to the demand for interactivity by internet users and the exploring of hypertext by advertisers. The big question is whether the newspapers will resist those demands, running the risk of becoming less relevant in the digital environment; or whether they will compromise, putting the values of journalism at risk.

Keywords: Journalism. Newspaper. Press. Media.

\section{ÍNDICE DE TABELAS}

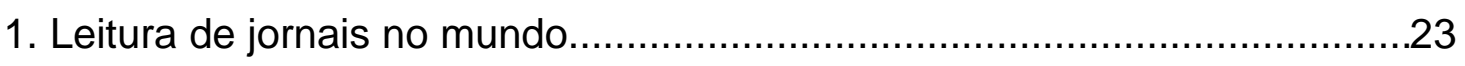

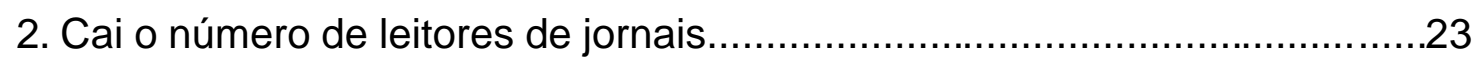




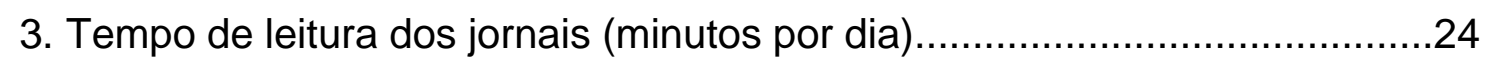

4. Percepção do consumo de outras mídias com o início do uso da web.........30

5. Circulação dos principais jornais brasileiros................................................

6. Vantagens e desvantagens de cada meio de comunicação...........................68

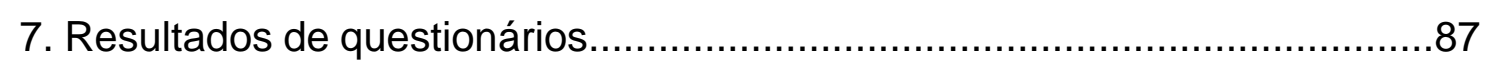

\section{ÍNDICE DE GRÁFICOS}

1. Diminui o número de exemplares por mil habitantes adultos.......................22

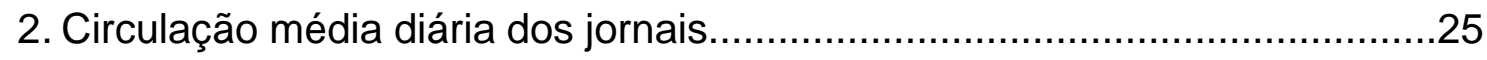

3. Variação da circulação média diária dos jornais.........................................25

4. Crescimento do PIB $x$ Circulação dos jornais.............................................26 


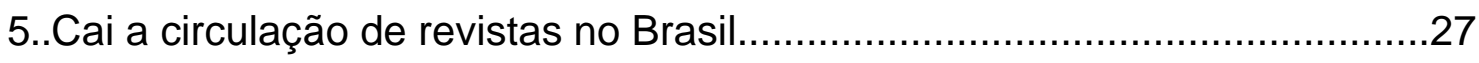

6. Cresce o número de jornais diários no Brasil............................................28

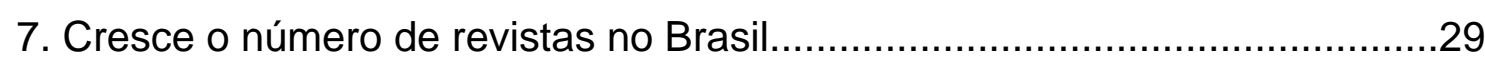

8. Faturamento bruto anual de todos os jornais do Brasil................................32

9. Faturamento bruto anual dos meios de comunicação de todo o Brasil..........33

10. Evolução dos índices de leitura da "Revista A".........................................55 


\section{ÍNDICE DE GRÁFICOS}

\section{RESUMO}

\section{ABSTRACT}

INTRODUÇÃO.

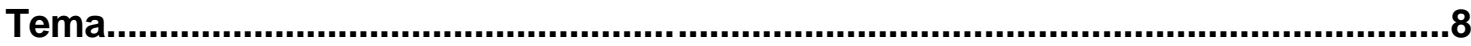

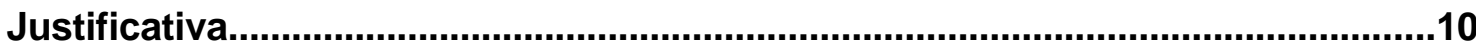

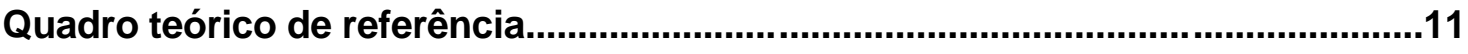

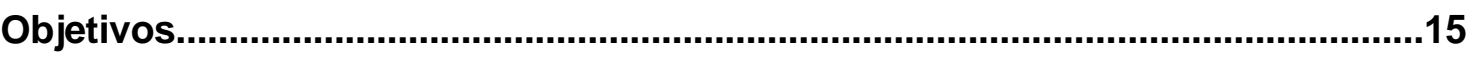

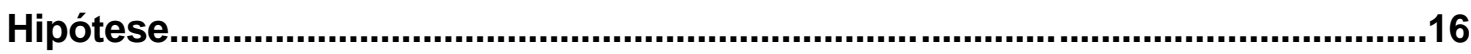

PROCEDIMENTOS METODOLÓGICOS...................................................................

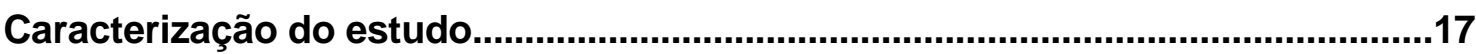

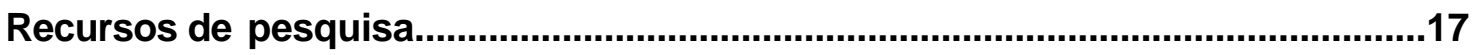

Metodologia de análise dos dados coletados......................................................19

CAPÍTULO 1 - MERCADO DA INFORMAÇÃO ....................................................21

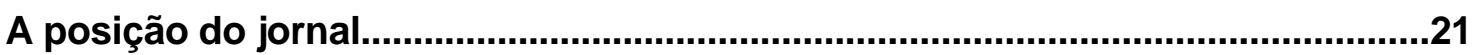

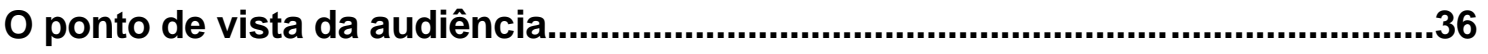

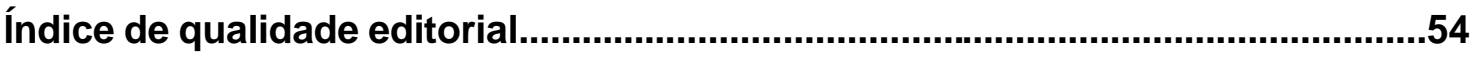

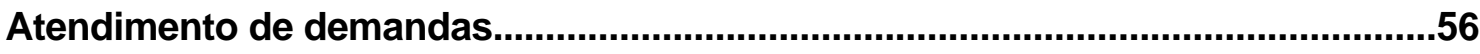

CAPÍTULO 2 - CONCEITOS E TENDÊNCIAS......................................................58

Motivações dos leitores....................................................................................59

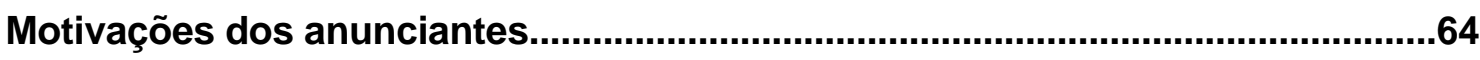

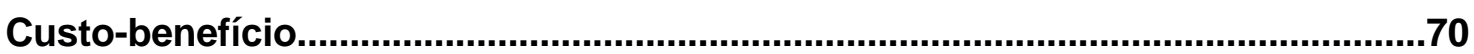

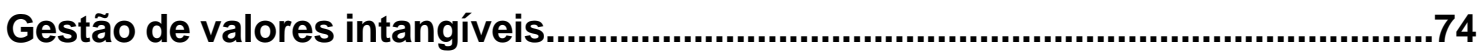

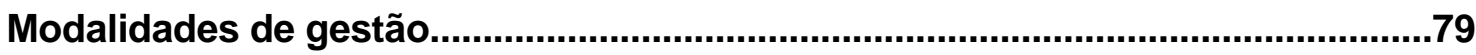

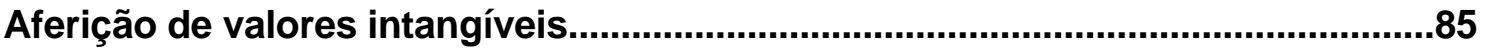

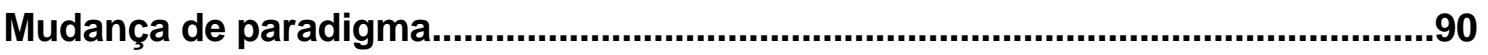

CAPÍTULO 3 - A RESPOSTA DOS JORNAIS......................................................93

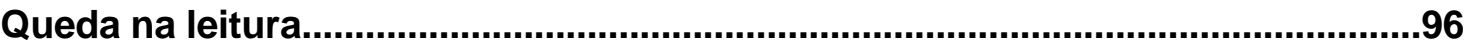

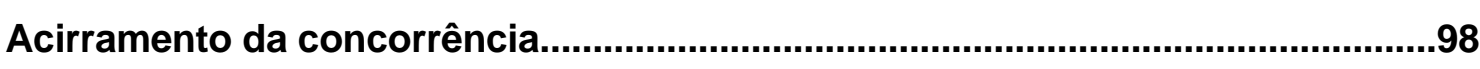

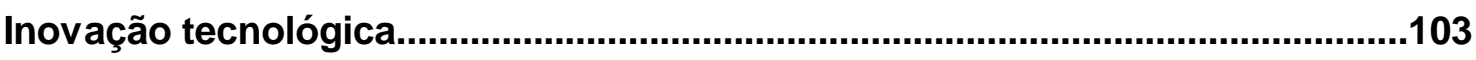

CAPÍTULO 4 - A VISÃO DE ESPECIALISTAS...................................................110

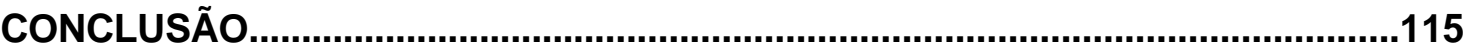

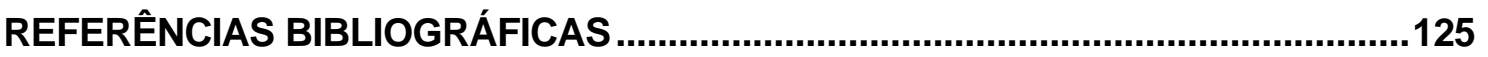




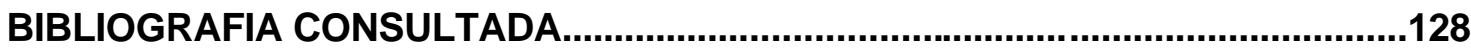

ANEXOS - ENTREVISTAS

Sandro Vaia

Otavio Frias Filho

Rodolfo Fernandes

Ramón Salaverría

Nicholas Negroponte 


\section{PRÓLOGO}

Este trabalho é uma tentativa de avaliar o impacto da concorrência dos outros meios, da mudança nos hábitos de leitura e da inovação tecnológica sobre o jornal, e como os três principais jornais do país respondem a esses desafios. $O$ jornal é encarado, aqui, como uma indústria, um negócio, um produto. O foco, se quisermos, está colocado sobre a forma, não sobre o conteúdo. Não se propõe aqui discutir questões vinculadas à praxis jornalística. Não se faz uma crítica da mensagem. Aceita-se o conteúdo como um dado, da mesma maneira como se assume que o modo de coexistência dos meios de comunicação está relacionado com os seus respectivos suportes tecnológicos.

Este não é um estudo de caráter epistemológico. Sua abordagem é, se quisermos, funcionalista. Conceitos como "influência", "prestígio" e "credibilidade", interessam, aqui, não pelas discussões que podem suscitar acerca de seu significado, mas simplesmente como qualidades que o públicoalvo dos meios de comunicação identifica ou não identifica nesses meios - e as conseqüências disso para o jornal.

O estudioso das Ciências da Comunicação certamente observará a influência das escolas americanas neste estudo. Embora autores europeus também sejam citados, predomina a abordagem funcionalista americana. Não se encontrarão, aqui, as análises de conteúdo acentuadamente inspiradas em escolas européias, como a de Frankfurt, ou, mais recentemente, dos Estudos Culturais - campos de pesquisa das Ciências da Comunicação que se têm mostrado férteis o bastante no Brasil.

\section{INTRODUÇÃO}


Na primeira metade desta década, os três principais jornais brasileiros - Folha de São Paulo, O Globo e O Estado de São Paulo - sofreram expressivas quedas de circulação. A circulação média diária da Folha caiu de 399.654 exemplares, em 2001, para 307.703, em 2004 - uma queda de $23 \%$. A do Globo diminuiu de 296.272 para 257.451 - ou 13\%. E a do Estado, de 341.300 para 233.471 - o que representa $31 \%$. Em 2005, a Folha manteve-se praticamente estável, com uma circulação média diária de 307.937 exemplares. O Estado seguiu em sua curva declinante, embora mais suave, com 230.859. O Globo, que, ao contrário dos jornais paulistas, não sofre concorrência direta de um grande jornal, foi o único a registrar uma recuperação significativa, de $6 \%$, alcançando 274.934 exemplares. ${ }^{1}$

Oscilações conjunturais à parte, parece improvável que os grandes jornais voltem a alcançar, algum dia, os recordes registrados em meados dos anos 90 (quando as edições dominicais da Folha ultrapassaram o milhão de exemplares), impulsionados, é verdade, por agressivas políticas de concessão de brindes, que ficaram conhecidos como anabolizantes.

A situação dos três grandes jornais brasileiros espelha uma tendência, tanto no âmbito nacional quanto no internacional. Em 2000, a média diária de circulação de todos os jornais brasileiros, somados, foi de 7,883 milhões de exemplares. Em 2004, esse número havia caído para 6,522 milhões. Em números absolutos, 2005 foi ano de recuperação, com esse número atingindo 6,780 milhões de cópias. Mas essa expansão não acompanhou o crescimento da população, já que o número de exemplares por mil adultos continuou caindo. De 64,2, em 2001, ele baixou para 45,3, em 2005.² Esse índice também está caindo na maioria dos países em que o dado está disponível para a Associação Mundial de Jornais. No Japão, o índice diminuiu de 668,7 exemplares por mil habitantes, em 2000, para 633,7, em 2005. No Reino Unido, de 408,5 para 348,0. Na Alemanha, de 375,2 para 305,2. E assim por diante. ${ }^{2}$

Pesquisa do Instituto Marplan, encomendada anualmente pela Associação Nacional de Jornais, indica que, na população de dez anos e mais, no Brasil,

\footnotetext{
${ }^{1}$ Fonte: Instituto Verificador de Circulação (IVC). Disponível no site da Associação Nacional de Jornais (ANJ), no endereço: http://www.anj.org.br/?q=node/177. Acessado em 12/12/2006.

2 Fonte: Associação Mundial de Jornais. Disponível no site da ANJ, no endereço: http://www.anj.org.br/?q=node/183. Acessado em 12/12/2006.
} 
37,060 milhões de pessoas eram leitoras de jornais em 2001. Em 2003, esse número havia caído para 35,853 milhões - ou $3,2 \%{ }^{3}$ Os dados indicam que não só menos pessoas estão lendo jornais, mas, também, por menos tempo. Sondagem feita anualmente pelo Ibope Monitor para a Associação Nacional de Jornais constatou que, em 2002, os leitores dedicavam, em média, 51 minutos à leitura dos jornais de segunda-feira a sábado, e 56 minutos, aos domingos. Em 2005, esse índice havia caído para 46 minutos de segunda a sábado e 51 minutos, aos domingos. ${ }^{4}$

A queda de circulação, de número de leitores e de tempo de leitura dos jornais coincide com o período de acirramento da concorrência de outros meios de informação, como a internet, as TVs por assinatura, as emissoras de rádio noticiosas e até mesmo as revistas semanais informativas. Todos esses meios disputam com os jornais não só a atenção da audiência, mas, também, as verbas publicitárias - ambos recursos finitos. Em 2000, o faturamento bruto anual de todos os jornais do Brasil somou $R \$ 3,594$ bilhões, em valores atualizados para dezembro de 2004. Em 2004, esse volume havia caído para $\mathrm{R} \$ 2,315$ bilhões. ${ }^{5}$ Entre 2003 e 2004, somente as revistas tiveram aumento de faturamento menor que os jornais. Na TV por assinatura, esse aumento foi de 61\%; na internet, de $35 \%$; na TV aberta, de $26 \%$; no rádio, de $19 \%$; nos jornais, de $15 \%$ e, nas revistas, de $11 \%{ }^{6}$

O aumento da concorrência e a queda de circulação e de receitas ocorreram num momento em que as empresas que publicam os três mais importantes jornais brasileiros - as Organizações Globo, o Grupo Estado e o Grupo Folha atravessavam dificuldades financeiras, resultantes de dívidas assumidas na década passada. No caso da Globo, o investimento de bilhões de reais na criação da infra-estrutura de TV a cabo; no do Estado, a participação na companhia de telefonia celular BCP, com uma fatia de cerca de US\$120 milhões; e no da Folha, a criação do portal de internet UOL, foram

\footnotetext{
${ }^{3}$ Disponível em:

http://www.anj.org.br/?q=node/179\&PHPSESSID $=10 \mathrm{dc} 083445 f 44 \mathrm{~b} 06 f 7 \mathrm{~d} 894 \mathrm{f} 85 \mathrm{fc} 3 \mathrm{~d} 1 \mathrm{c} 5$.

Acessado em 12/12/2006.

4 Disponível em http://www.anj.org.br/?q=node/179. Acessado em 12/12/2006.

${ }^{5}$ Fonte: Projeto Inter-Meios. Tabelas disponíveis em:

http://www.projetointermeios.com.br/controller.asp?acao=relatoriolnvestimento\#. Último acesso: 12/12/2006.

${ }^{6}$ Idem. Os números não estão corrigidos pela inflação.
} 
investimentos que não tiveram a rentabilidade esperada e os compromissos financeiros, feitos em dólar, tornaram-se um peso quase insustentável a partir da desvalorização do real, em 1999. ${ }^{7}$

As dificuldades financeiras motivaram a profissionalização da gestão do Grupo Estado, com os membros da família Mesquita recuando dos cargos de direção do dia-a-dia da empresa para seus assentos no Conselho de Administração. A família Marinho já havia efetuado essa transição nas Organizações Globo, na década passada. A família Frias é a única que, das três, mantém-se na gestão cotidiana do Grupo Folha. A experiência internacional, sobretudo nos Estados Unidos e na Inglaterra, indica que há uma tendência, conforme se consolida a fusão de veículos rumo à convergência dos meios de comunicação, de as tradicionais empresas de famílias compostas por jornalistas darem lugar a gestores profissionais e, num segundo momento, com a abertura de capital, a acionistas vindos de fora.

Essas mudanças nas modalidades de gestão e de propriedade têm implicações importantes sobre a cultura da empresa e sobre sua política de investimentos na atividade-fim, o jornalismo. Executivos formados noutros setores tendem a demonstrar menos propensão a aceitar investimentos que não garantem rentabilidade no curto prazo, e que configuram "caprichos de jornalistas", como grandes reportagens, custosas coberturas, manutenção de redes de correspondentes, cadernos e suplementos culturais. ${ }^{8}$ A economia das empresas jornalísticas é formada por valores intangíveis, como credibilidade, prestígio, projeção e influência. Não há, na cultura dessas empresas - e não só no Brasil -, o hábito de criar ferramentas para traduzir esses valores intangíveis em linguagem contábil, como rentabilidade e ativos. ${ }^{9}$

As dificuldades financeiras das empresas que editam os três grandes jornais brasileiros ocasionaram cortes de investimentos, demissões nas redações, diminuições de gastos com viagens e outras despesas vinculadas à realização de reportagens, além de adiar projetos de lançamentos de novos produtos, como cadernos e suplementos. Esse desinvestimento na qualidade dos jornais

\footnotetext{
${ }^{7}$ Cf. LOBATO, 2004.

${ }^{8}$ Cf., p. ex., MEYER, 2004; FULLER, 1996; DOWNIE JR. e KAISER, 2002.

9 Para uma discussão sobre valores intangíveis na economia da informação, v. STIGLITZ, 2001.
} 
se deu quando os leitores demonstravam, nas pesquisas qualitativas realizadas pelos próprios jornais, insatisfação com os seus produtos. Atraídos pelas informações em tempo real na internet e no rádio, pelos programas noticiosos e documentários nas TVs a cabo, pela sofisticação dos produtos gráficos e dos textos nas revistas semanais, e premidos por uma diminuição em seu tempo dedicado à leitura diária, os leitores demonstram interesse decrescente pelos jornais.

Para as novas gerações, que experimentam na infância os estímulos do videogame, do computador e da própria internet, o jornal em papel pode revelar-se um meio opaco, inerte e desinteressante. Para audiências que demandam a informação em tempo real, o jornal pode parecer desatualizado. $\mathrm{Na}$ outra ponta, para uma demanda mais sofisticada, por histórias bem contadas e contextualizadas, análises bem escritas e completas, e um produto gráfico mais bem acabado, a revista semanal pode suprir as necessidades melhor que os jornais.

Como reagir a esses desafios? O jornal impresso, tal como o conhecemos, está fadado ao desaparecimento?

De acordo com a Newspaper Association of America, o número de usuários que acessam páginas de jornais na internet aumentou $21 \%$ em 2005, na comparação com 0 ano anterior. Em número de páginas visitadas, 0 crescimento foi de $43 \% .{ }^{10}$ Quantos leitores migrarão para a internet, passando a ler apenas as suas versões online? Quanto de sua circulação se manterá no atual suporte de papel? É cedo para dizer. Mas já se podem discutir as possíveis implicações, nos âmbitos jornalístico, comercial e industrial, da migração, ainda que parcial, do ambiente de papel para o ambiente online e em rede.

Tanto na esfera do negócio quanto na do fazer jornalístico, as tecnologias digitais de difusão da informação abrem novas possibilidades para os jornais, seja no sentido de sua convergência com outros meios, seja na incorporação dessas ferramentas para a confecção e comercialização do produto jornal, isoladamente.

\footnotetext{
${ }^{10}$ Cf. BARBOSA, 2006.
} 
A interatividade, propiciada pela internet, possibilita uma troca sem precedentes entre as redações e os leitores, que podem contribuir com pautas, informações e feedback sobre o produto do trabalho jornalístico. Igualmente, no campo comercial, os anunciantes passam, potencialmente, a ter, por meio dessa interatividade, uma gama espetacular de informações sobre o seu público-alvo, e também de feedback sobre suas campanhas publicitárias, permitindo uma contínua afinação de suas estratégias, de acordo com as reações desse público.

O hipertexto, também propiciado pela internet, inaugura novas possibilidades de entrecruzamento de conteúdos jornalísticos, oferecendo os múltiplos contextos de uma informação. E, no plano da publicidade, permite uma associação instantânea entre conteúdos de informação, mensagens publicitárias e operações de marketing e de vendas de produtos. Tudo isso, permeado por informações sobre os usuários, que alimentam um banco de dados que se aperfeiçoa continuamente e permite afinar as estratégias de publicidade, marketing e vendas.

A informação em rede, uma terceira característica essencial da internet, completa o quadro das inovações que abrem novos horizontes para 0 jornalismo e para as estratégias comerciais dos meios digitais. $\mathrm{Na}$ rede, as informações se tornam disponíveis simultaneamente. Em vez de uma edição diária que substitui a do dia anterior, os produtos de informação na internet vêm colocar-se, embora em primeiro plano, ao lado de todas as outras informações já veiculadas, compondo um formidável banco de dados que permite ao usuário, mais uma vez, contextualizar a informação presente, à luz de informações passadas.

A disputa por audiência e receita com os meios online, assim como as possibilidades novas de explorar o universo da informação e da publicidade impõem, no dia-a-dia das redações e dos departamentos comerciais, uma série de novos problemas e inquietações. A mais importante delas, talvez, diga respeito justamente à relação entre ambos os territórios. Até que ponto o trabalho jornalístico pode estar integrado às estratégias comerciais de um veículo de informação? Nos portais de informação da internet, entre os editores da produção de conteúdo jornalístico e os chefes da área comercial, tem 
surgido a figura de um gerente responsável pela coordenação entre as pautas jornalísticas e as estratégias de venda de espaço publicitário e de marketing. Este é um conceito que parece violar a chamada "separação entre Igreja e Estado", que se consolidou, nos jornais e noutros meios de informação, como pilar da independência editorial e da credibilidade.

No campo mais específico do ofício de jornalista, a possível combinação de ferramentas de apuração também representa um novo desafio. Os novos meios convergentes demandam notícias em forma de texto, fotografia, vídeo e áudio. A digitalização de gravadores e câmeras permite a mescla dessas linguagens no ato da apuração pelo repórter. A prática de alguns meios digitais de encarregar seus repórteres de voltar para a redação com conteúdos em mais de uma linguagem deu origem à expressão "jornalista de mochila", e a questionamentos sobre a possível queda de qualidade na apuração jornalística, dada a sobrecarga de tarefas e de preocupações com aspectos técnicos, por mais simplificadas que sejam as operações dos novos aparelhos digitais ${ }^{11}$.

No interior das redações, independentemente do grau de migração dos jornais para o ambiente online, a incorporação das tecnologias de bancos de dados e de informação em rede pode também mudar as práticas jornalísticas. Essas tecnologias possibilitam compartilhar informações apuradas e acumuladas para benefício de todos. Mas na premissa dessa mudança reside, em alguma medida, a conformação de um novo perfil de jornalistas, no qual o individualismo e o protagonismo cederiam algum espaço para o trabalho em equipe. O trabalho de apuração da reportagem, como empreitada solitária, fortemente marcada por talentos pessoais que funcionam como marcas distintivas aliadas ao nome de um profissional, perderia parte de seu papel.

Como essas transformações do ofício, aliadas a eventuais mudanças de cultura e de prioridades resultantes da profissionalização da gestão das empresas, alteram o produto final jornalístico?

Do ponto de vista dos custos, a eventual migração do suporte de papel para a internet retiraria um enorme fardo dos ombros das empresas de informação. Os

${ }^{11}$ Cf. STONE, 2002. Sobre a introdução da prática no Brasil, o caso mais recente é o do Grupo Lance, que unificou suas equipes de reportagem do jornal impresso, da internet, de rádio e de televisão, oferecendo treinamento sobre o uso dos equipamentos multimídia. Cf.

JORNALISTAS \& CIA, 2006. 
gastos com impressão e distribuição dos jornais correspondem, em média, a um terço dos seus custos ${ }^{12}$. A outra ponta, a da receita, é obviamente uma incógnita. Os meios de informação da internet ainda estão aprendendo a ganhar dinheiro com suas operações, assim como o mercado publicitário ainda está experimentando com esses novos meios, embora a cada ano a internet atraia mais e mais recursos de mídia.

Para além de uma equação financeira que ainda não tem elementos para ser fechada, o fato é que essa migração deslocaria os jornais do setor industrial, no qual se encontram parcialmente, para o setor de serviços, que parece ser, em última análise, o seu hábitat natural. Com isso, é provável que as empresas de informação possam concentrar-se mais no que constitui o seu core business. Quem talvez tenha expressado as implicações dessa eventual conversão com mais eloqüência - e otimismo - é o publisher do jornal The New York Times, Arthur Sulzberger:

Newspapers cannot be defined by the second word - paper. They've got to be defined by the first - news. All of us have to become agnostic as to the method of distribution. We've got to be as powerful online, as powerful in TV and broadcasting, as we are powerful in newsprint. (...) I do not care when we print our last newsprint edition. We will remain the major source of news and information in this country and perhaps the world. We will do it on the Web. We will do it on television. We will do it in print. (GATES, 2002)

A utilização, na internet, do conteúdo produzido pelas redações dos jornais de papel já é uma realidade, e as empresas devem readequar-se a ela, na sua busca de um reequilíbrio entre despesas e receitas. A gerente de Projetos Especiais da Associação Mundial de Jornais (WAN), Martha Stone, adverte que os consumidores do conteúdo produzido pelos jornais não são apenas os que os compram diretamente nas bancas ou os assinam. São também os que consomem os conteúdos por eles produzidos e veiculados por outros veículos, como a internet. Stone cita pesquisa realizada em outubro de 2005 pela Associação de Jornais da América, segundo a qual até $15 \%$ dos leitores de jornais nos Estados Unidos os lêem na internet. Stone observa que os dados sobre circulação física dos jornais não incluem parte dos leitores jovens e de alto poder aquisitivo, que estão lendo os jornais pela internet. E propõe uma

\footnotetext{
${ }^{12}$ A fonte da informação são os diretores de redação, da Folha, Otavio Frias Filho, do Estado, Sandro Vaia, e do Globo, Rodolfo Fernandes, em entrevistas concedidas ao autor, em novembro de 2005, transcritas em Anexos.
} 
ampliação do conceito de "circulação" para o de "audiência", abrangendo os vários canais de alcance dos jornais. "Todos dependemos de multimídia", diz Stone. "Precisamos estar atentos para vender o churrasco ao invés de vender apenas a carne". (JORNAL ANJ, outubro de 2006)

Como se vê, o jornal - e o próprio jornalismo - ingressa numa era de transformações em todas as suas dimensões. Independentemente de seu grau de convergência com os outros meios no ambiente da internet, o negócio do jornal e o seu produto não serão o mesmo daqui a alguns anos. Perscrutar essas mudanças é um trabalho ao mesmo tempo complexo e instigante.

\section{Tema}

O tema deste estudo são as transformações empresariais e editoriais pelas quais o jornal deve passar nos próximos anos, como conseqüência das inovações tecnológicas, das mudanças de comportamento e de demandas de seu público-alvo, e das novas realidades dos mercados publicitário e da venda de informações.

Uma sucessão de perguntas emerge quando se olha para essa temática de forma abrangente. Como os jornais devem reagir às novas oportunidades que esses recursos oferecem, e às ameaças que as pressões da concorrência dos outros meios impõem? Em que medida os jornais assimilarão esses recursos? Quanto de sua tiragem migrará do suporte de papel para o online? Como será a convivência entre esses dois meios? Eles são necessariamente concorrentes, ou podem ser complementares? Do ponto de vista do conteúdo, por que tipo de remodelação os jornais devem passar, para diferenciar-se e firmar-se como um produto com um valor específico perante a concorrência dos outros meios? Até que ponto os jornais podem coordenar suas estratégias comerciais com as rotinas da redação, sem pôr em risco sua independência e credibilidade? Como ficará a correlação entre custo e receita, com a redução ou eventual eliminação - da operação industrial e com os novos patamares de captação de receitas introduzidos pela internet?

O objeto da pesquisa está delimitado em três jornais: O Estado de São Paulo, Folha de São Paulo e O Globo. São os três maiores do País, não no sentido estritamente quantitativo: a circulação do jornal Extra, do Rio (média diária de 
274.015 em $2005^{13}$ ) equipara-se à do Globo e supera a do Estado. Mas no sentido também qualitativo, de jornais que, além de estarem entre os de maior tiragem do País, projetam-se como jornais nacionais, tanto na sua abrangência territorial e temática quanto na sua influência. São jornais que buscam cobrir os temas de relevância nacional e influir nas tomadas de decisão de políticos e empresários no nível nacional. São, também, jornais que se propõem a preservar sua saúde financeira e a diversidade de suas carteiras de anunciantes, ambas como pré-condição do que consideram como sua independência editorial.

Evidentemente, essa delimitação é discutível. Seria possível ampliar o escopo da pesquisa, para jornais que tiveram essa projeção, como o Jornal do Brasil; para jornais que buscam essa projeção, como o Correio Braziliense; para jornais que a possuem na esfera do jornalismo econômico, como a Gazeta Mercantil e o Valor Econômico; ou mesmo para jornais de forte projeção local, como o Jornal da Tarde, o Diário de São Paulo, o Estado de Minas, a Zero Hora e assim por diante. Entretanto, o Jornal do Brasil perdeu algumas das características essenciais que o faziam pertencer ao mesmo grupo do Estado, da Folha e do Globo. A família Nascimento Brito, que, como a Mesquita, a Frias e a Marinho, foi proprietária do jornal no período em que ele se consolidou como um dos mais importantes do país, arrendouto, no ano 2000, por 50 anos, a um empresário, Nelson Tanure, sem tradição no ramo, retirando-Ihe uma das características básicas dos outros três, que é a imagem editorial fortemente identificada com a presença de uma família de jornalistas. $O$ arrendamento se seguiu a um drástico desinvestimento, na segunda metade dos anos 90, reduzindo significativamente o número de jornalistas, a circulação, a penetração nacional e a qualidade do produto. O Correio explora uma temática de abrangência nacional, colocando no topo de sua hierarquia os grandes temas políticos e econômicos. Mas sua circulação e penetração não têm a mesma abrangência dos três grandes jornais. Luiz Fernando Levy, herdeiro da Gazeta, também a arrendou em 2003 a Nelson Tanure, por 60 anos, em meio a uma crise com efeitos similares aos do JB. Além disso, a Gazeta e o Valor são jornais que, por sua temática focada em economia e negócios e por sua

\footnotetext{
${ }^{13}$ Fonte: IVC/ANJ.
} 
tiragem menor, não pertencem ao grupo dos três grandes. E, finalmente, os grandes jornais locais por definição não aspiram à projeção nacional, a começar pela sua temática, que prioriza os assuntos da cidade ou do Estado, e também por sua circulação e penetração locais.

O Estado, a Folha e o Globo formam um conjunto relativamente homogêneo. Têm perfis de custos industriais e logísticos semelhantes, receitas e margens de lucro próximas; pagam salários equiparáveis; adotam critérios editoriais próximos; têm finalidades, problemas e soluções parecidos. Por tudo isso, são reconhecidos como os três grandes jornais do País. E serão tratados, de maneira geral, nesta pesquisa, como um único objeto, salientando-se diferenças entre eles apenas quando forem relevantes.

\section{Justificativa}

No conjunto dos meios de informação, os jornais ocupam um papel de destaque, tanto dos pontos de vista político, social e cultural, quanto como objeto das ciências da comunicação. Para nos circunscrevermos à história do Brasil, e lançando mão de um único exemplo, basta lembrar que o jornal $O$ Estado de S. Paulo foi fundado em 1875 por um grupo de abolicionistas e republicanos, com a finalidade de lutar contra a escravidão e o regime monarquista. Desde então, o Estado, assim como outros grandes jornais brasileiros, tem sido central na promoção de debates e na veiculação de idéias e de informações. Os recentes escândalos políticos que desnudaram as práticas de corrupção, de tráfico de influência e de mau uso do poder, historicamente entranhadas na cultura política do país, tiveram como dois momentos-chave entrevistas publicadas por dois jornais: a do ex-deputado Roberto Jefferson, concedida à Folha em maio de 2005, e a do caseiro Francenildo Costa, ao Estado, em março de 2006. Os exemplos, obviamente, são inúmeros.

Os grandes jornais são os únicos meios, no Brasil, e geralmente noutros países também, cujas redações são formadas por centenas de jornalistas, em contraste com as emissoras de TV e de rádio, revistas e sites da internet, cujos profissionais se contam às dezenas. Os jornais são os meios mais estruturados para produzir apuração genuína de informação. Tanto que costumam pautar os demais meios. 
Para que possam seguir desempenhando esse papel, e para que o façam melhor ainda, os grandes jornais precisam assegurar e consolidar sua saúde e independência financeiras - até para arcar com os custos das transformações tecnológicas, de capacitação de pessoal e formulação de uma nova cultura organizacional e jornalística, que os tempos exigem. Um veículo vulnerável do ponto de vista financeiro é mais suscetível de vergar sob o peso das pressões político-econômicas que governos e grupos empresariais procuram exercer sobre os meios de informação.

As importantes transformações no mercado publicitário e no público-alvo decorrentes da consolidação das novas tecnologias e também de mudanças dos hábitos de leitura, descritas anteriormente, representam grandes desafios para a lucratividade dos grandes jornais. Sua estrutura industrial, suas práticas jornalísticas e comerciais precisam ser repensadas, à luz dessas transformações, sob pena de o negócio jornal tornar-se inviável, ou de o seu produto desfigurar-se ao ponto de perder-se o que é essencial no jornal e no jornalismo.

Até onde é do conhecimento deste autor, não existe ainda, no Brasil, um estudo sobre as injunções tecnológicas, comerciais, industriais e jornalísticas da inserção dos jornais na sociedade da informação. Hoje, as empresas que editam os três jornais estão com suas dívidas, já mencionadas, equacionadas, e os três registram lucros líquidos ${ }^{14}$. Isso torna o momento oportuno para estudar as perspectivas desses veículos, separando a crise conjuntural dos problemas estruturais.

\section{Quadro teórico de referência}

Este trabalho remonta à vertente teórica dos Estudos Culturais, inaugurada em 1964 por Stuart Hall, Raymond Williams, David Harvey, E.P. Thompson e Richard Hoggart, no Centre for Contemporary Cultural Studies, da Universidade de Birmingham (Inglaterra). Essa escola privilegia a interação entre cultura e meios de comunicação, levando em conta aspectos subjetivos, particulares, em busca de traços que permitam elaborar uma concepção geral de um fenômeno social.

\footnotetext{
${ }^{14}$ A fonte da informação são os três diretores de redação, nas entrevistas ao autor, mencionadas na nota 11 .
} 
Este estudo perpassa necessariamente disciplinas diversas, analisando dados empíricos e examinando aspectos econômicos, psicossociais e culturais, ao lado daqueles afeitos diretamente à Ciência da Comunicação. Daí que seu ambiente é o da interdisciplinaridade, um dos traços primordiais dos Estudos Culturais, como assinala Douglas Kellner:

O estudo cultural opera com uma concepção interdisciplinar que utiliza teoria social, economia, política, história, comunicação, teoria literária e cultural, filosofia e outros discursos teóricos. (KELLNER, 2001, p. 42)

Na mesma direção, Ana Carolina Escosteguy realça características dessa linha teórica que parecem propícias para o exame de desejos, motivações e identidades que levam a escolhas como as dos meios de informação pela audiência; assim como para a análise de comportamento nas empresas, nas redações e no mercado publicitário:

A observação contemporânea de um processo de estilhaçamento do indivíduo em múltiplas posições e/ou identidades transforma-se tanto em tema de estudo quanto em reflexo do próprio processo vivido atualmente pelo campo dos Estudos Culturais: descentrado geograficamente e múltiplo teoricamente. (ESCOSTEGUY, 2001, p. 168)

Outra característica deste trabalho, também lastreada na tradição dos Estudos Culturais, é a preocupação com o "receptor", ao lado da atenção dada ao meio e ao emissor. Conceitos que, por sinal, tendem a confundir-se, no ambiente de interatividade instaurado pelos meios digitais:

Os estudos culturais se disseminaram por várias áreas do saber, como história e literatura, mas, para efeito de análise, adotam-se esses estudos aplicados à comunicação. O que logo de início chama atenção é o olhar sem preconceitos sobre a interação da mídia com a instância receptora, que nessa perspectiva é marcada pela negociação entre ambas - produção e recepção. (DALMONTE, 2002, p 13)

Essa interação, no ambiente da sociedade da informação, é um ângulo-chave para este trabalho. Sandra Azevêdo assinala que o ponto de diálogo entre os estudos culturais e a comunicação está justamente no conceito de interação:

A interação nos ajuda a pôr em entendimento estes dois campos de saberes distintos - estudos culturais e comunicação -, e converge para lançarmos, entre outras coisas, novas observações sobre as pesquisas de recepção, promovendo [...] todo um conjunto de investigações no âmbito da audiência, especialmente da televisão, buscando entender o que fazem os públicos com os meios de comunicação de massa e as mensagens que emitem [...]. (AZEVÊDO, 2003, p 8)

Por último, como observa Azevêdo, os estudos de recepção realizados no âmbito dos Estudos Culturais valorizam a liberdade individual do receptor ${ }^{15}$, em

${ }^{15}$ Idem, p 9. 
detrimento da visão segundo a qual o seu consumo dos produtos de informação estaria sobredeterminado pela imposição de uma indústria de comunicação de massa, conforme as convicções da Escola de Frankfurt. Essa também é a premissa deste trabalho: a de que a audiência escolhe livremente os meios para se informar.

Outro recorte teórico deste estudo, também marcado pela interdisciplinaridade e pela consideração dos fatores subjetivos, é a Teoria da Complexidade, representada pelo historiador, sociólogo e filósofo Edgar Morin. Dados os múltiplos vetores que concorrem nas correlações entre os aspectos tecnológico, comercial, industrial e jornalístico, torna-se necessário abordar o problema da inserção do jornal na sociedade da informação considerando, como faz Morin, "a predominância da conjunção complexa". ${ }^{1}$ (MORIN, 2001, p. 113)

Na mesma linha de abordagem da complexidade, embora fora do âmbito da Teoria da Complexidade, Manuel Castells, que observa que "a sociedade é um sistema complicado, repleto de interações causais que reconfiguram e redirecionam inovações tecnológicas para usos inesperados". (CASTELLS e INCE, 2003, p 25)

Enquanto Morin e Castells rejeitam sobredeterminações, preferindo uma teia complexa de interrelações sistêmicas, outros autores definem a sociedade da informação como aquela em que a informação tem o papel predominante. Gabriel Cohn, por exemplo, escreve que a "sociedade da informação é aquela cuja forma é sobredeterminada pela informação". ${ }^{1}$ (COHN, 2000, pp 21-22) Aqui, Cohn está preocupado com a distinção entre comunicação e informação: enquanto a primeira se ocupa da transmissão de conteúdos, a segunda responde pela escolha do que deve ser veiculado. Assim, para além da discussão teórica acerca da sobredeterminação ou não da informação na sociedade da informação, tem, para este estudo, utilidade a definição de Cohn da relação da informação com o valor, que, para nós, reveste-se de caráter intangível:

Seu domínio é o da seleção daquilo que terá valor significativo e que, com base nesse valor, comporá o campo dos conceitos aptos a integrarem a comunicação. (COHN, 2000, pp 21-22) 
A par desse quadro teórico de referência, a literatura recente contém exemplos de estudos com enfoques parcialmente semelhantes. Nos Estados Unidos, alguns estudos têm procurado estabelecer critérios e até mesmo propor modelos para a avaliação de ativos intangíveis, como a credibilidade, a isenção, a solidez de opiniões e outros, associados a determinado título. O jornalista Jack Fuller, em seu News values: ideas for an information age, de 1996, analisa dados de pesquisas nos Estados Unidos, procurando mostrar a correlação entre os valores intangíveis, que ele reúne sob o conceito de "influência", e dados palpáveis como a circulação e penetração dos jornais. O economista James Hamilton faz um estudo minucioso das variáveis desse negócio, em All the news that's fit to sell: how the market transforms information into news, de 2004. Os valores centrais do jornalismo e os riscos que correm na sociedade da informação são escrutinados em The vanishing newspaper: saving journalism in the information age, que o professor Philip Meyer publicou em 2004. As implicações das inovações tecnológicas, do surgimento dos novos meios e de sua possível convergência são amplamente mapeados em Rethinking media change: the aesthetics of transition, editado por David Thornburn e Henry Jenkins. Os jornalistas Leonard Downie Jr. e Robert G. Kaiser, ambos de The Washington Post, analisam as mudanças de cultura e de prioridades com a substituição das empresas familiares de jornalistas por executivos profissionais formados noutros setores, em The news about the news: american journalism in peril, de 2002.

Já na Espanha, a ênfase tem sido colocada nas mudanças na linguagem e na aplicação das ferramentas tecnológicas nas redações de jornais tradicionais e de meios digitais e seus desdobramentos para o kzer jornalístico. Um dos trabalhos mais completos, nesse campo, é a coletânea Manual de redacción ciberperiodistica, coordenada por Javier Díaz Noci e Ramón Salaverría (2003). Nela, o pesquisador Xosé López García, por exemplo, observa que as possibilidades de navegação horizontal da internet, interligando textos diferentes, e de interatividade imediata com os usuários permitem à informação alcançar um novo valor agregado. A informação se torna mais fácil de assimilar, ao mesmo tempo potencialmente mais rica e, portanto, mais atraente: 
O acesso não seqüencial à construção da informação supõe a possibilidade de organizar os conteúdos mediante distintas formas que assegurem um tratamento a fundo, assim como uma apresentação atraente que facilite ao usuário conseguir os dados e entendê-los. O autor da narração jornalística, embora não tenha o mesmo protagonismo que na informação seqüencial, na qual fixa o princípio e o fim do texto, deve dispor de uma apresentação completa da mensagem que deseja transmitir, de itinerários básicos, de fontes documentais e de opções criativas. (NOCl e SALAVERRÍA, 2003, p 389)

Nessa linha de produção espanhola, deve-se citar também a coletânea de papers Toward new media paradigms: content, producers, organisations and audiences, editada por Ramón Salaverría e Charo Sábada, que também analisa as potencialidades que as inovações tecnológicas oferecem para 0 novo jornalismo. Ou a análise dos desafios para a gestão das empresas de informação na sociedade da informação, por Alfonso Sánchez-Tabernero, em El futuro de las empresas de comunicación: estratégias para un mundo impredecible, também de 2003.

No Brasil, o campo de pesquisas sobre os meios digitais tem-se mostrado mais fértil que sobre os jornais. Dentre as produções mais recentes, encontram-se Estratégias para a mídia digital: internet, informação e comunicação (2003), de Beth Saad, centrado na gestão das empresas na sociedade da informação; Jornalismo digital, de Pollyana Ferrari (2003), e a tese de doutorado defendida, também em 2003, por Maria Regina Cardeal na ECA/USP, Do jornal ao portal.

\section{Objetivos}

O objetivo geral deste estudo é analisar como os três principais jornais do País - Folha, Globo e Estado - estão lidando e pretendem lidar, no futuro próximo, com o acirramento da concorrência com outros meios, inclusive os eletrônicos, com as inovações tecnológicas e com as mudanças de hábitos dos leitores.

Para tanto, os objetivos específicos são:

1) Contextualizar o problema no quadro geral de transformações experimentadas pelos jornais e pelo jornalismo, no Brasil e no mundo.

2) Apresentar o cenário recente brasileiro, descrevendo como a concorrência dos outros meios, as inovações tecnológicas e as mudanças de hábitos dos leitores têm afetado esses três jornais. 
3) Examinar como as direções de redação dos três jornais avaliam esses três fatores, e como estão se preparando para posicionar os respectivos veículos no mercado.

\section{Hipótese}

Os três principais jornais do País devem enfrentar a concorrência dos outros meios investindo nas qualidades que os diferenciam deles. A ênfase deve-se deslocar da notícia, pura e simples, para a qualidade da narrativa - histórias bem contadas, com início, meio e fim. Eles também devem investir na contextualização, na análise e na interpretação da notícia. Os jornais continuarão a contar o que aconteceu ontem, mas agregarão sentido à notícia. E nisso se diferenciarão dos outros meios e procurarão assegurar o seu espaço num ambiente de concorrência crescente.

\section{PROCEDIMENTOS METODOLÓGICOS}

\section{Caracterização do estudo}


Este é um estudo essencialmente exploratório e descritivo. Diante da multiplicidade de fontes e de indícios com que trabalha, ele se enquadra na modalidade do Estudo de Caso, tal como a define Robert Yin: "uma investigação empírica sobre um fenômeno contemporâneo no contexto da vida real, em que a fronteira entre o fenômeno e o contexto não é claramente evidente e múltiplas fontes de evidência são utilizadas". (YIN, 1989, p. 23)

Nesta pesquisa, pode-se considerar que está presente a maioria - se não todas - das fontes de dados usadas na coleta de evidências de um estudo de caso: documentos, registros em arquivo, entrevistas, observação direta, observação participante e artefatos físicos. (Cf. MATSUUCHI DUARTE, in DUARTE e BARROS, 2005, p.229) É o que se verá a seguir.

\section{Recursos de pesquisa}

Os dados serão coletados das seguintes fontes:

1. Levantamento de dados quantitativos e qualitativos. Tratados como fontes secundárias, esses dados foram coletados junto a entidades e empresas que atuam no setor:

1.1. Dados quantitativos: séries históricas estatísticas sobre circulação dos jornais, tempo de leitura e faturamento, fornecidas pela Associação Nacional de Jornais, pela Associação Mundial de Jornais, pelo Instituto Verificador de Circulação, pelo Projeto Inter-Meios e pelo Ibope Monitor.

1.2. Pesquisa qualitativa. $O$ autor obteve $\mathrm{O}$ relatório completo do resultado de uma pesquisa de focus group ${ }^{16}$, encomendada por um grande jornal brasileiro e realizada em 2003, com 13 grupos das classes $A$ e $B_{+}$, divididos segundo gênero, faixa etária, faixa de renda e fonte predominante de informação: jornais Estado e Folha; jornais Jornal da Tarde e Diário de São Paulo; revistas semanais de informação; TVs por

\footnotetext{
${ }^{16}$ Modalidade de pesquisa qualitativa na qual um pequeno grupo de pessoas previamente selecionadas, com perfil sócio-econômico, nível de instrução e hábitos de consumo semelhantes, é motivado por um mediador a discutir temas e a responder perguntas por ele propostos. Pesquisadores e os clientes que contratam a pesquisa assistem às discussões do outro lado de um vidro espelhado. As sessões são filmadas. Ao final, os pesquisadores elaboram um relatório detalhado sobre as opiniões e sentimentos dos diversos grupos.
} 
assinatura; emissoras de rádio; internet. Dado o alto custo de realização de uma pesquisa desse porte, o autor optou por aproveitar o acesso a essa pesquisa, realizada por um grande instituto, especializado em focus group. $\mathrm{O}$ autor assumiu compromisso de não revelar quem contratou $\mathrm{e}$ quem realizou a pesquisa. Todos os outros dados estão disponíveis para este estudo. Embora os questionamentos apresentados pelos pesquisadores guardem semelhanças com aqueles feitos neste estudo, a rigor, não foi o autor que elaborou as questões nem conduziu a pesquisa. Portanto, a pesquisa foi utilizada, aqui, como fonte secundária. Ainda assim, o relatório, de 240 páginas, forneceu rico material sobre os hábitos, preferências, desejos e visões dos consumidores de informações. Os diretores de redação entrevistados utilizam essa e outras pesquisas da mesma natureza como fundamento para várias de suas análises e conclusões.

2. Revisão da literatura. Estudos nos Estados Unidos, na Europa e no Brasil descrevem o surgimento e a consolidação dos novos meios que concorrem com os jornais e analisam as suas reações, do ponto de vista da assimilação de teconologias, de mudanças na gestão das empresas e de remodelações gráficas e editoriais.

3. Entrevistas com os diretores de redação. De roteiro aberto, exploratórias e flexíveis, as entrevistas com os diretores dos três jornais que são objeto da pesquisa, Otávio Frias Filho, da Folha, Rodolfo Fernandes, do Globo, e Sandro Vaia, do Estado. ${ }^{17}$ foram realizadas em novembro de 2005. Elas abordam o impacto das novas tecnologias, do acirramento da concorrência e das mudanças dos hábitos de leitura sobre os respectivos jornais. Os diretores falam, também, sobre aquilo que está sendo ou que será mudado, e aquilo que deve permanecer, para fazer face aos desafios da sociedade da informação. Descrevem a crise da primeira metade desta década e falam da retomada iniciada em 2005. E dão sua visão sobre até que ponto seus jornais deverão trocar o suporte de papel pelo digital e como devem se qualificar para atrair os leitores.

\footnotetext{
${ }^{17}$ Vaia deixou o cargo 11 meses depois da entrevista, em outubro de 2006.
} 


\section{Entrevistas com especialistas e pesquisadores internacionais. Centradas no} tema, porém de roteiro aberto, exploratórias e flexíveis ${ }^{18}$, elas servem de subsídio à revisão da literatura, e de atualização conceitual, num cenário de mudanças muito aceleradas.

4.1. Em entrevista concedida em dezembro de 2004, em São Paulo, Ramón Salaverría, diretor do Laboratório de Comunicação Multimídia da Faculdade de Comunicação da Universidade de Navarra, em Pamplona (Espanha), descreve as mudanças nos hábitos de leitura e as reações dos jornais e meios digitais a essas mudanças. Salaverría é um pesquisador de campo, conhecedor da realidade na Europa, nos Estados Unidos e no Brasil, país que visitou diversas vezes. Ele editou a coletânia de papers Towards new media paradigms: contents, producers, organisations and audiences (2004) e coordenou o Manual de redacción ciberperiodística (2003).

4.2 Nicholas Negroponte, co-fundador do Media Laboratory do Massachusetts Institute of Technology (MIT), em Boston (EUA), concedeu sua entrevista em julho de 2005, em Brasília, quando veio apresentar ao governo brasileiro seu programa "Um Laptop por 100 Dólares". Pesquisador de uma instituição de ponta, também com larga experiência de campo em várias partes do mundo, e autor do clássico Vida digital (1995), Negroponte dá sua visão sobre a convergência dos meios e sobre o impacto das tecnologias digitais nas comunicações, processos dos quais é um participante ativo.

\section{Metodologia de análise dos dados coletados}

Os resultados não poderão ser generalizados, como se fixassem uma relação de causalidade necessária. Na linha dos Estudos de Caso, eles serão tratados como indícios, evidências, que apontam tendências do que se passa no variado e complexo universo dos meios de comunicação em geral e dos grandes jornais brasileiros, em particular.

\footnotetext{
${ }^{18}$ Jorge Duarte define assim esse tipo de entrevista: "Tem como ponto de partida um tema ou questão ampla e flui livremente, sendo aprofundada em determinado rumo de acordo com aspectos significativos identificados pelo entrevi stador (...)." (DUARTE, 2005, p. 65)
} 
O material coletado nas entrevistas e nas fontes secundárias será organizado conforme a técnica de análise de conteúdo, visando extrair respostas às questões e atingir os objetivos da pesquisa. $O$ método da análise de conteúdo permite ordenar tanto os dados quantitativos coletados nesta pesquisa estatísticas sobre circulação, hábitos de leitura e faturamento de jornais quanto os qualitativos - pesquisa focus group, entrevistas com pesquisadores e diretores de redação -, e fazer inferências a partir desse conjunto diverso e complexo de dados. (Cf. FONSECA JR., in DUARTE, 2005, p.281)

Dessa análise resulta um conjunto de inferências sobre as funções desempenhadas pelos diversos meios de comunicação, as atitudes do públicoalvo face a essa gama de opções, as estratégias dos três principais jornais brasileiros para garantir e ampliar seu espaço nesse ambiente competitivo, o papel da tecnologia, os modelos de gestão e o pano de fundo internacional.

\section{CAPÍTULO 1 - MERCADO DA INFORMAÇÃO}


O meio jornal tem enfrentado nos últimos anos um acirramento da concorrência por diversos outros meios. A internet bombardeia uma audiência que passa cada vez mais horas na frente de um computador com notícias em tempo quase real. As emissoras de rádio dedicam cada vez mais tempo às notícias, e também atingem um número crescente de ouvintes, sobretudo no carro, presos nos congestionamentos das grandes cidades. O crescimento vertiginoso das emissoras de TV a cabo também aumenta o leque de opções de notícias, documentários e análises. As revistas semanais, por sua vez, procuram atender cada vez mais os desejos dos leitores, expressos em pesquisas qualitativas. Diante do leque variado de fontes audiovisuais de informação, os índices de leitura têm caído.

Depois de ter atingido picos elevados nos anos 90, a circulação dos jornais vem caindo nesta década. Numa ilustração de quanto o bolo tem tido de ser dividido, o número de títulos de jornais tem aumentado, enquanto a tiragem total diminui. Um público cada vez mais exigente e segmentado escolhe de uma cesta crescente de opções as suas fontes de informação. É um público sedento de informação, mas que adquiriu o hábito de diversificar as suas fontes, de acordo com o momento do dia ou mesmo a fase de sua vida.

É em meio a esse complexo cenário que o jornal tenta assegurar e ampliar o seu espaço. Para descrevê-lo, coletamos dados quantitativos e qualitativos. Os dados quantitativos traçam, em séries históricas, a trajetória percorrida pelo jornal nos últimos anos, separadamente ou em paralelo com os seus concorrentes. Os dados qualitativos, colhidos de uma pesquisa de focus group, retratam as expectativas, sentimentos, hábitos e preferências do público consumidor de informação, e como ele encara o jornal e os outros meios.

São os dois lados do mesmo fenômeno: o do jornal e o de seus potenciais leitores.

\section{A posição do jornal}

A cada dia que passa, uma fatia menor da população brasileira está lendo jornais diários impressos. Em 2001, o último ano em que esse indicador cresceu, havia 64,2 exemplares de jornal para cada mil brasileiros adultos. De lá para cá, esse número vem caindo, ano após ano, chegando a 45,3, em 2005 
(ver gráfico 1). O índice coloca o Brasil em 50. lugar, num ranking de 94 países, divulgado pela Associação Mundial de Jornais.

\section{FIGURA 1}

Diminui o número de exemplares por mil habitantes adultos

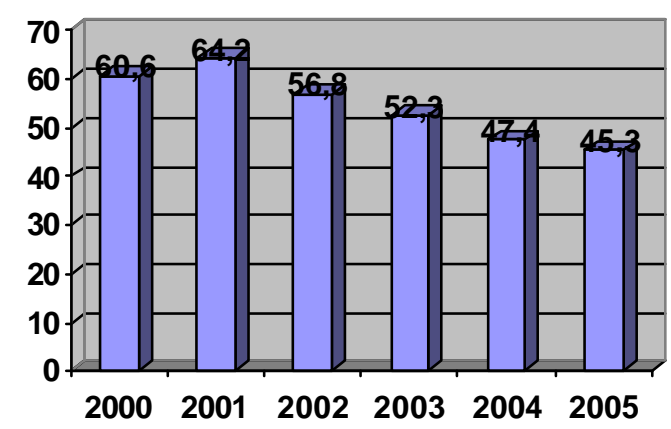

Fonte: Associação Nacional de Jornais (ANJ) ${ }^{19}$

Trata-se de um fenômeno mundial. O número de exemplares por mil habitantes não está caindo em todos os países do mundo, mas está caindo na maioria dos países em que o dado está disponível para a Associação Mundial de Jornais. A queda atinge boa parte dos países mais avançados e mais ricos do mundo. $O$ número de exemplares por mil habitantes caiu em todos os países do G-7, o grupo dos sete países com maior Produto Interno Bruto (PIB), entre 2000 e 2005 (tabela 1).

\section{TABELA 1}

\footnotetext{
${ }^{19}$ Disponível no endereço www.anj.org.br, assim como todos os outros dados citados da ANJ. Acesso em outubro de 2006.
} 


\section{Leitura de jornais no mundo}

(Circulação média/população adulta - cópias por mil habitantes)

\begin{tabular}{|l|c|c|c|c|c|c|}
\hline País & 2000 & 2001 & 2002 & 2003 & 2004 & 2005 \\
\hline Japão & 668.7 & 664.0 & 653.5 & 646.9 & 644,2 & 633,7 \\
\hline Reino Unido & 408.5 & 383.4 & 402.4 & 393.4 & 331,6 & 348,0 \\
\hline Alemanha & 375.2 & 371.1 & 332.8 & 321.9 & 313,0 & 305,2 \\
\hline Estados Unidos & 263.6 & 274.1 & 269.2 & 263.2 & n.d. & 249,9 \\
\hline Canadá & 205,7 & 189,0 & 324,4 & 337,3 & 198,7 & 181,0 \\
\hline França & 190.0 & 180.7 & 164.1 & 167.0 & 160,3 & 159,6 \\
\hline Itália & 121,4 & 127,8 & 117,9 & 157,9 & 114,5 & 114,3 \\
\hline
\end{tabular}

Fonte: ANJ/Associação Mundial de Jornais (WAN) ${ }^{20}$

No Brasil, a queda do número de exemplares por habitantes é consistente com a queda na fatia da população que lê jornal. Em 2001, 31\% dos entrevistados pelo Instituto Marplan declararam ler jornal às segundas-feiras, 30\% de terça a sábado e 36\% aos domingos. Em 2003, essas porcentagens haviam caído para $25 \%$, $25 \%$ e $30 \%$, respectivamente. Ou seja, uma queda de $20 \%$, em apenas dois anos (tabela 2).

\section{TABELA 2}

Cai o número de leitores de jornais

(Por dias da semana, no Brasil)

\begin{tabular}{|l|c|c|c|}
\hline Ano & 2003 & 2002 & 2001 \\
\hline Total geral & 35.853 .000 & 35.097 .000 & 37.060 .000 \\
\hline Seg. & $25 \%$ & $28 \%$ & $31 \%$ \\
\hline Ter. a sáb. & $25 \%$ & $29 \%$ & $30 \%$ \\
\hline Domingo & $30 \%$ & $33 \%$ & $36 \%$ \\
\hline
\end{tabular}

Fonte: ANJ/XLV Estudos Marplan - Filtro: Ambos os sexos, 10 e + anos

Mais contundente ainda, no entanto, é que o índice de leitores de jornais caiu também em números absolutos nesse período, de 37,060 milhões para 35,853

${ }^{20}$ Idem. 
milhões. Assim, o problema não é só que a circulação não esteja crescendo na mesma velocidade que a população, mas que o número de leitores está diminuindo.

A cada ano que passa, além de haver menos leitores, aqueles que lêem o fazem por menos tempo. Em 2001, os leitores de jornal dedicavam 64 minutos à leitura de segunda a sábado. Em 2005, esse tempo havia caído para 46 minutos - uma redução de $28 \%$ em apenas quatro anos. A leitura de domingo também sofreu redução, ainda que menor: de 56 minutos, em 2002, para 51, em 2005 (tabela 3).

\section{TABELA 3}

Tempo de leitura dos jornais (minutos por dia)

\begin{tabular}{|l|c|c|}
\hline Ano & Segunda a sábado & Domingo \\
\hline 2005 & 46 & 51 \\
\hline 2004 & 47 & 54 \\
\hline 2003 & 50 & 54 \\
\hline 2002 & 51 & 56 \\
\hline 2001 & 64 & n. d. \\
\hline
\end{tabular}

Fonte: Ibope Monitor - Tempo dedicado a ler ou folhear um exemplar de jornal ${ }^{21}$

Com menos pessoas lendo jornais, e por menos tempo, o número de exemplares rodados diariamente no Brasil caiu entre 2000 e 2003. Naquele ano de 2000, quando chegou ao pico da série histórica desde 1990, circularam, em média, quase 8 milhões de exemplares por dia. Em 2004 e 2005, esse número voltou a subir (ver gráfico 2).

\footnotetext{
${ }^{21}$ Pesquisa realizada anualmente, divulgada no site da Associação Nacional de Jornais, no endereço: http://www.anj.org.br/?q=node/179. Último acesso: 13/12/2006
} 
GRÁFICO 2 - Circulação média diária dos jornais

$\square$ Mil exemplares/dia

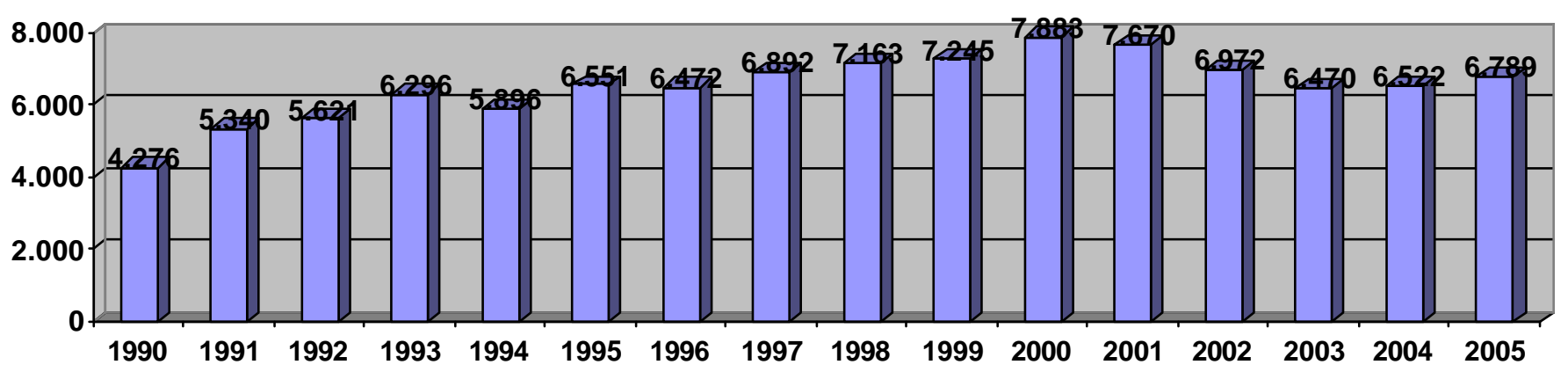

Fonte: $\mathrm{ANJ}^{22}$

Em termos de variação porcentual, o pior ano foi o de 2002, seguido pelo de 2003. De 2004 para 2005, o crescimento foi expressivo (gráfico 3).

GRÁFICO 3 - Variação da circulação média diária dos jornais

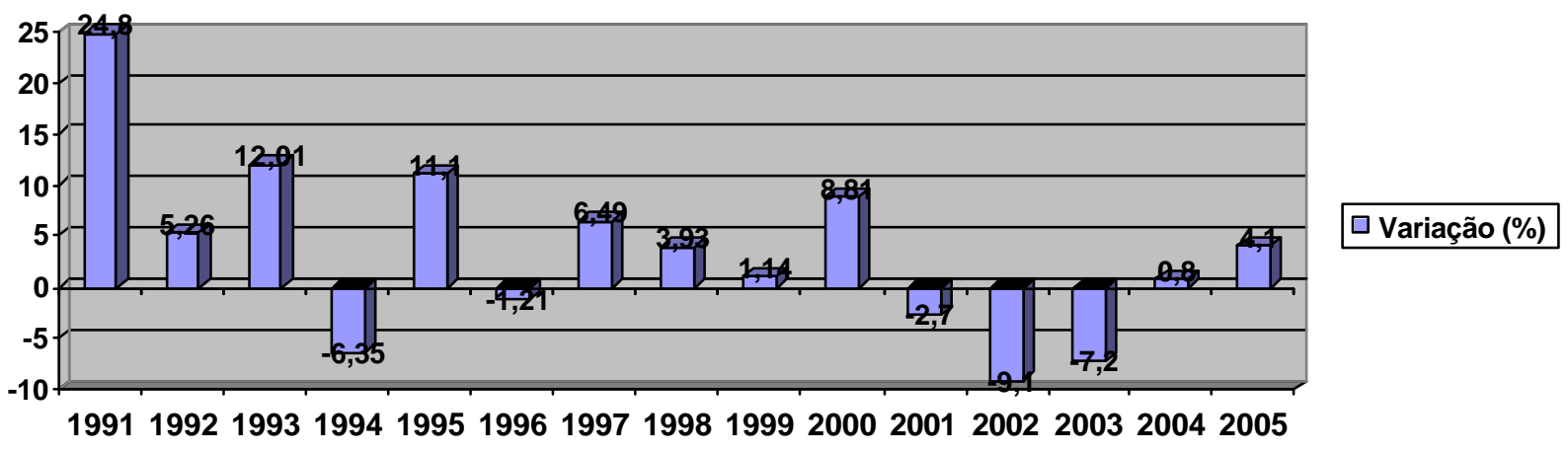

Em 2006, a aceleração continuou. Em agosto daquele ano, o Instituto Verificador de Circulação registrava um aumento de 6,5\% da circulação (PAULINO, 2006b). É uma recuperação significativa, embora não suficiente para retornar aos patamares da virada desta década.

Em princípio, espera-se que haja uma relação entre a variação da circulação dos jornais e o crescimento do Produto Interno Bruto (PIB). Como acontece com outros bens e serviços, o consumo de jornais, os anúncios publicitários e classificados tendem a crescer quando a economia cresce.

${ }^{22}$ Disponível no endereço: http://www.anj.org.br/?q=node/170. Último acesso: 16/12/2006. 
O coordenador executivo do Núcleo de Mercado do Comitê Anunciante da ANJ, Geraldo Leite, faz essa análise da queda de circulação na primeira metade da década:

Acredito que a queda tenha acontecido principalmente devido ao fator econômico. Faltou dinheiro, e despesas tipicamente de classe média, entre elas jornais, revistas, internet, TV paga, celular, tiveram de disputar espaço. (PAULINO, 2006b)

No gráfico 4, comparamos o comportamento da economia brasileira com a variação da circulação dos jornais, nos últimos cinco anos:

GRÁFICO 4 - Crescimento do PIB x Circulação dos jornais

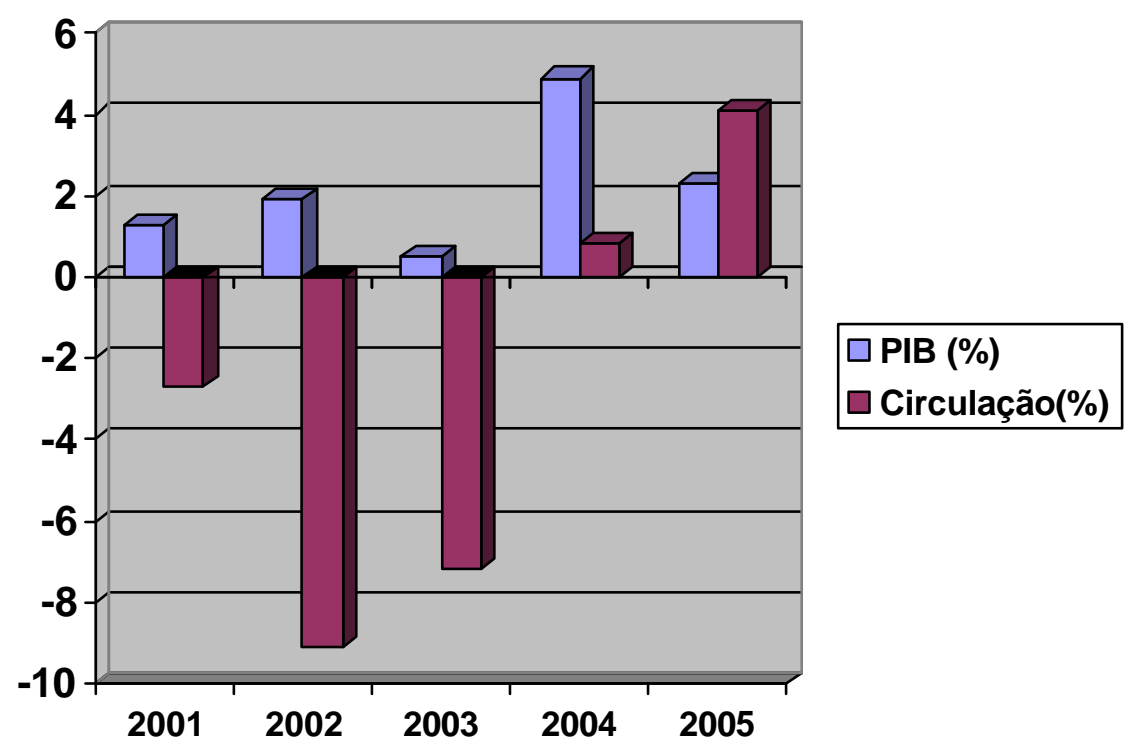

Fontes: IBGE ${ }^{23} / \mathrm{ANJ}$

O PIB brasileiro aumentou 1,3\% em 2001. Já a circulação de todos os jornais diários caiu 2,7\%. Em 2002, a economia brasileira cresceu 1,9\%, enquanto a circulação diminuiu 9,1\%. Em 2003, o PIB aumentou 0,5\% e a circulação voltou a encolher 7,2\%. Em 2004, a economia teve um crescimento mais robusto, de $4,9 \%$, e pela primeira vez no período a circulação reagiu, crescendo $0,8 \%$. 0

\footnotetext{
${ }^{23}$ A série histórica do PIB brasileiro, medido pelo Instituto Brasileiro de Geografia e Estatística (IBGE), pode ser vista no site do Banco Central, no endereço:

http://www.bcb.gov.br/pec/indeco/Port/ie1-51.xls. Último acesso: 16/12/2006
} 
ano de 2005 foi o único em que a circulação cresceu mais que o PIB: 2,3\% e $4,1 \%$, respectivamente.

Quando há um descolamento entre o comportamento da economia e o desempenho de um determinado setor, infere-se que fatores estruturais estejam influindo decisivamente nesse desempenho. Tudo indica que seja esse o caso.

A circulação das revistas no Brasil também tem caído ano a ano, sem registrar sequer a recuperação obtida pelos jornais a partir de 2004. O dado parece conduzir à inferência de que um fator decisivo nesse fenômeno é a diminuição dos hábitos de leitura, que afetaria ambos os meios.

GRÁFICO $5^{24}$ - Cai a circulação de revistas no Brasil
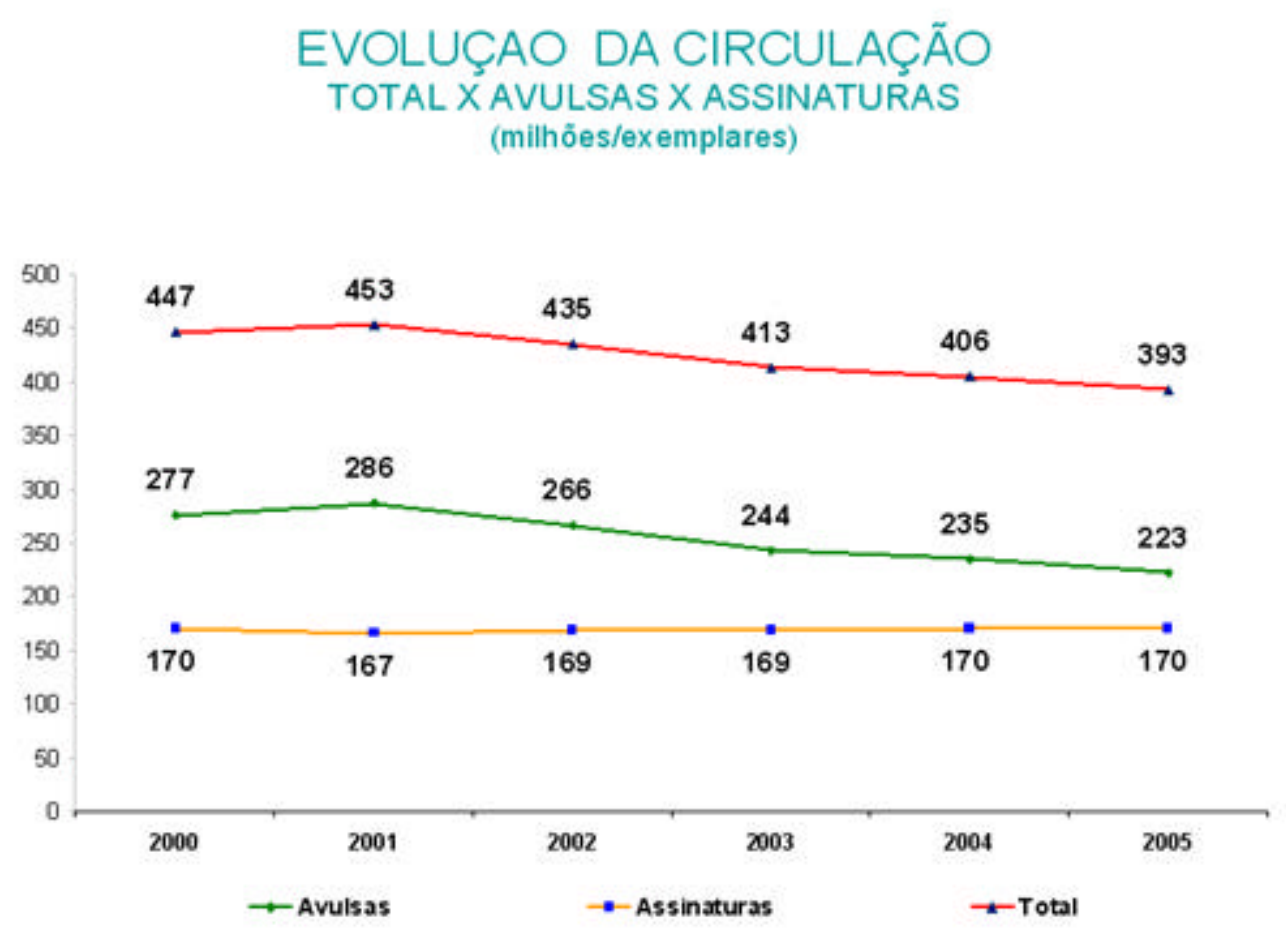

Fonte: IVC e Distribuidoras

\footnotetext{
${ }^{24}$ Gráfico extraído do site da Associação Nacional de Editores de Revistas. Disponível no endereço: http://www.aner.org.br/conteudo/1/artigo1862-1.asp. Último acesso: 13/12/2006
} 
Também é interessante notar que o número de títulos de jornais no Brasil está crescendo. De 491, em 2001, saltou para 532, em 2004 - um aumento de 8\% em apenas três anos (gráfico 6).

GRÁFICO 6 - Cresce o número de jornais diários no Brasil

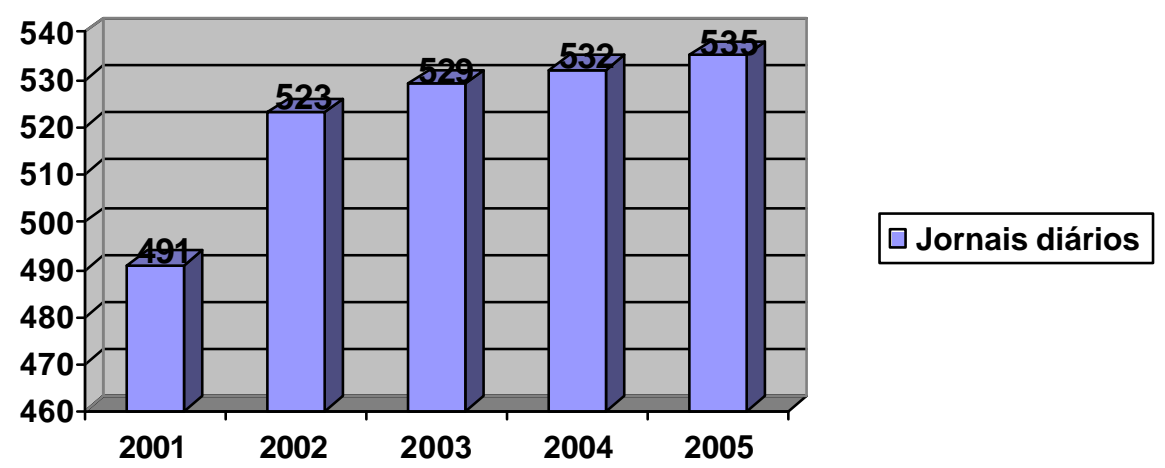

Fonte: $\mathrm{ANJ}^{25}$

Nesse mesmo período, a queda no número de exemplares foi de $15 \%$. O dado sugere o aumento no número de jornais de menor circulação. É provável, portanto, que os grandes jornais também estejam sofrendo concorrência de pequenos jornais, além dos outros meios.

Com as revistas, tem ocorrido o mesmo fenômeno. Ao mesmo tempo em que diminuiu, como vimos no gráfico 4 , o número total de exemplares publicados, aumentou o número títulos (gráfico 7)

${ }^{25}$ Disponível no endereço: http://www.anj.org.br/?q=node/13. Último acesso: 16/12/2006 


\section{Total de Títulos}

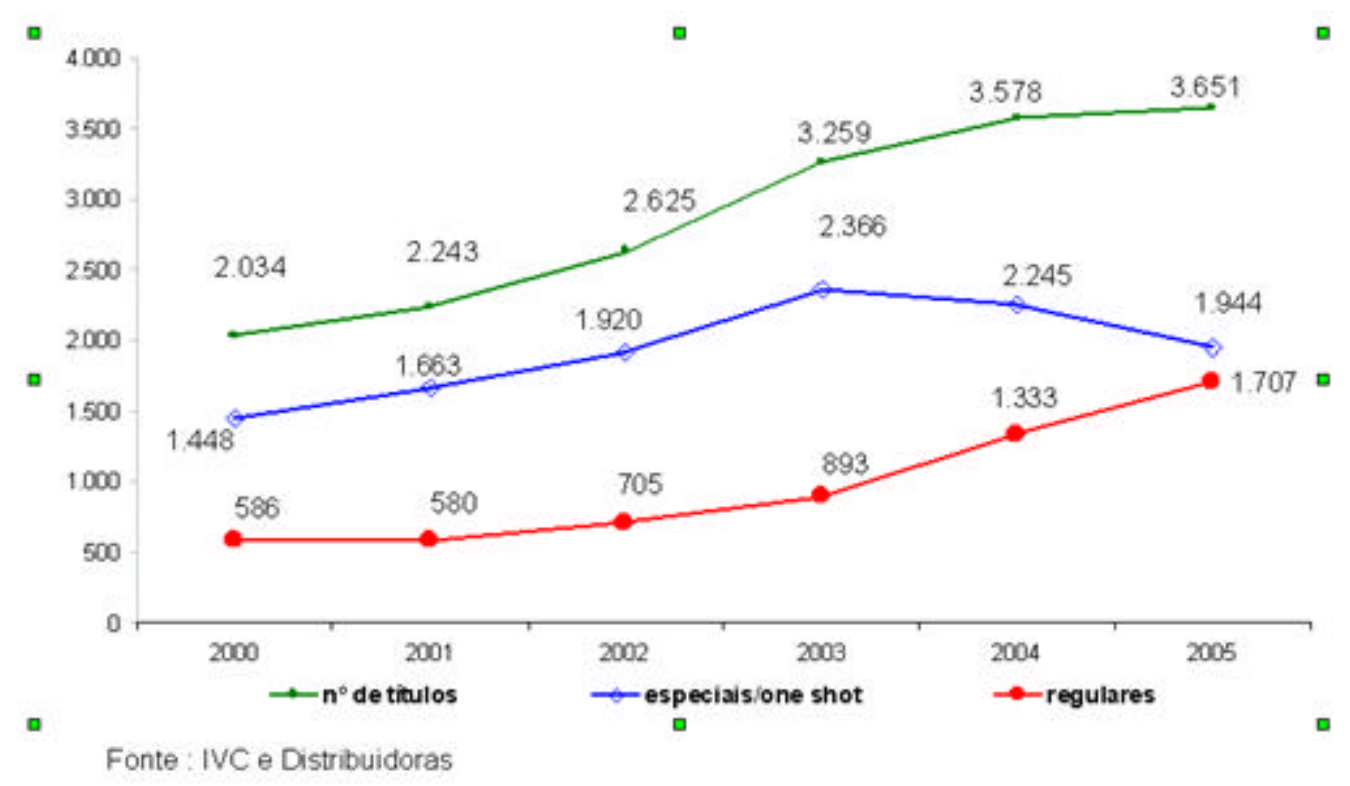

Como se vê, o número de revistas publicadas apenas uma vez - as edições especiais, chamadas de one shot - caiu. O que aumentou foi o número de títulos regulares. Portanto, o que se tem é um aumento no número de revistas publicadas regularmente, mas uma diminuição na tiragem geral das revistas, em número de exemplares. Assim como acontece com os jornais, o dado sugere um aumento no número de revistas com tiragens menores, já que mais títulos, mas com tiragens menores, resultam numa circulação total menor. No caso das revistas, é possível que esse dado indique o aumento na proporção de títulos especializados. Um segmento em que esse aumento foi visível, nos últimos anos, foi o das revistas sobre informática.

Em resumo, pode-se inferir desse conjunto de dados que as pessoas estão dedicando menos tempo à leitura e estão comprando menos exemplares de revistas e jornais. E parte do tempo dedicado à leitura se deslocou dos jornais e revistas de grande circulação para jornais locais e revistas especializadas. Como se verá no próximo capítulo, esse movimento é coerente com uma

\footnotetext{
${ }^{26}$ Gráfico extraído do site da Associação Nacional de Editores de Revistas. Disponível no endereço: http://www.aner.org.br/conteudo/1/artigo1861-1.asp.último acesso: 13/12/2006
} 
mudança de ênfase no consumo de informações, do maciço e global para o individualizado e o local, descrita na literatura.

Há, também, um deslocamento considerável para a internet. Enquanto diminuiu a circulação de jornais, aumentou o acesso à internet no Brasil. De acordo com dados do lbope, dos 63 milhões de pessoas com mais de 16 anos e telefone fixo em casa, 44,9\% (ou 28,3 milhões) tinham acesso à internet, no início de 2002. No fim de 2005 , essa fatia tinha aumentado para $53,1 \%$ (ou 33,4 milhões). Isso representa um ingresso de 5,1 milhões de novos usuários, em apenas quatro anos. (JULIASZ, 2006)

Mais da metade $(57,6 \%)$ dessas pessoas que acessam a internet no Brasil buscam nela notícias e informação - o cardápio principal dos jornais -, segundo pesquisa também do Ibope, realizada em março de 2006. (JULIASZ, 2006)

Como resultado, parte considerável do tempo antes dedicado aos jornais se deslocou para a internet. Estudo do professor Marcelo Coutinho (apud JULIASZ, 2006) mostra que o consumo de jornais foi o que mais diminuiu, depois do da televisão, em razão do uso da internet. Quatro em cada dez pessoas dizem que passaram a ler menos os jornais, depois que começaram a acessar a rede (tabela 4):

\section{Tabela 4}

Percepção do consumo de outras mídias com o início do uso da web

\begin{tabular}{|l|l|l|l|l|l|}
\hline Percepção & Televisão & Rádio & Jornais & Revistas & Livros \\
\hline Aumentou & $3 \%$ & $11 \%$ & $12 \%$ & $15 \%$ & $21 \%$ \\
\hline Diminuiu & $47 \%$ & $35 \%$ & $41 \%$ & $30 \%$ & $25 \%$ \\
\hline Não mudou & $50 \%$ & $54 \%$ & $47 \%$ & $55 \%$ & $54 \%$ \\
\hline
\end{tabular}

Fonte: JULIASZ, 2006

Examinemos, agora, o comportamento dos três jornais que são objeto deste estudo. A circulação média diária da Folha de São Paulo caiu de 399.654, em 2001, para 307.937, em 2005 - uma queda de $23 \%$-, mesmo tendo registrado ligeira recuperação de 2004 para 2005. A de O Globo diminuiu de 296.272, em 
2001, para 257.451, em 2004 - ou 13\%. Mas voltou a subir em 2005, aumentando 6\% em relação ao ano anterior. E a de O Estado de São Paulo manteve a curva declinante no período, caindo de 341.300, em 2001, para 230.850 , em 2005 - o que representa 32\% (tabela 4).

\section{TABELA 5}

Circulação dos principais jornais brasileiros

\begin{tabular}{|l|c|c|c|c|c|}
\hline Jornal & 2001 & 2002 & 2003 & 2004 & 2005 \\
\hline Folha de S.Paulo & 399.654 & 346.333 & 314.908 & 307.703 & 307.937 \\
\hline O Globo & 296.272 & 266.185 & 253.410 & 257.451 & 274.934 \\
\hline O Estado de S.Paulo & 341.300 & 268.433 & 242.755 & 283.471 & 230.850 \\
\hline
\end{tabular}

Fonte: Instituto Verificador de Circulação (IVC). Circulação média diária de janeiro a dezembro.

Ao lado da queda na circulação, houve também uma queda no faturamento dos jornais. Em valores atualizados pelo IGPM para dezembro de 2004, todos os jornais brasileiros faturaram, juntos, $R \$ 3,594$ bilhões em 2000. Em 2004, esse faturamento foi de $\mathrm{R} \$ 2,315$ bilhões - uma queda de $35 \%$ em quatro anos (gráfico 8). 
GRÁFICO 8 - Faturamento bruto anual de todos os jornais do Brasil (em R\$ milhões de dezembro/2004)

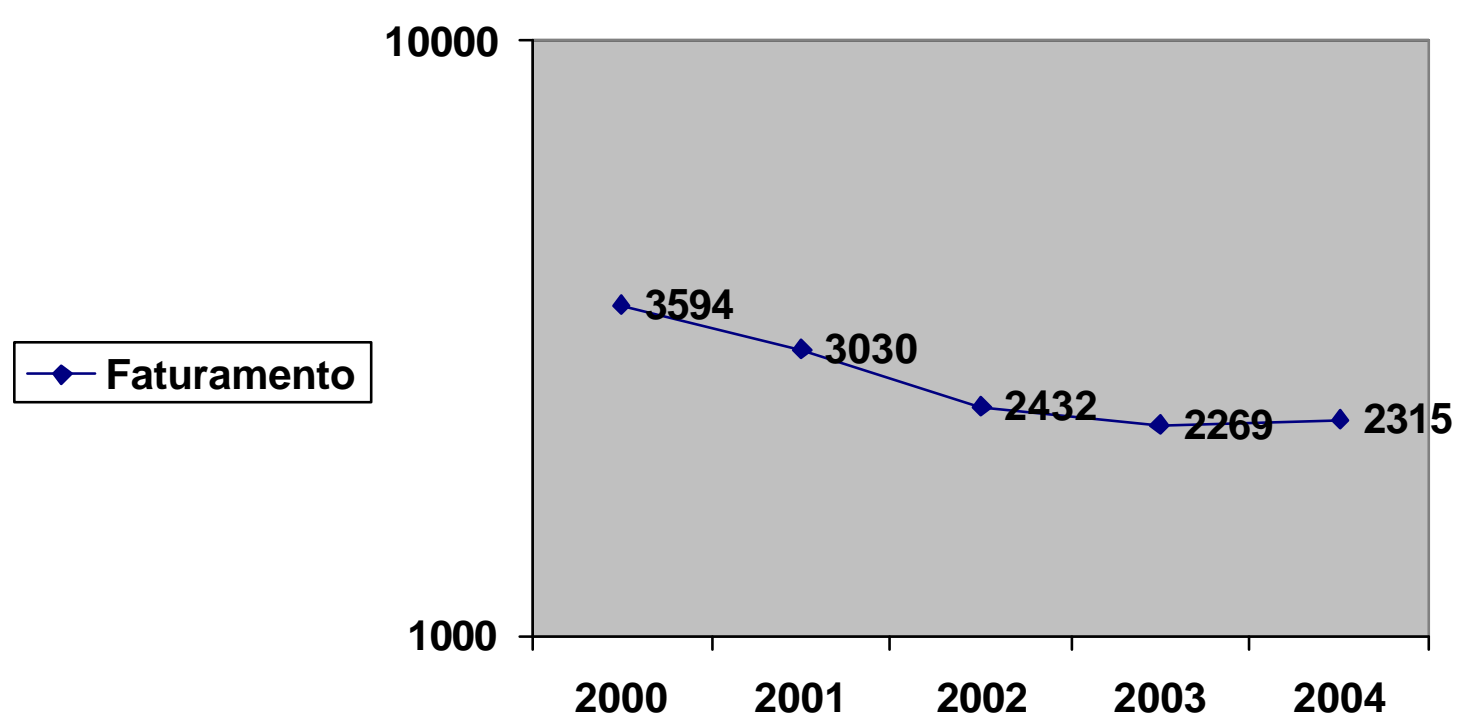

Fonte: Projeto Inter-Meios

Obs.: Valores corrigidos pelo IGPM-FGV para dezembro de 2004.

Num grande jornal brasileiro, tipicamente, a receita de circulação - assinaturas mais venda avulsa - representa cerca de $25 \%$ do total; a de classificados, outros $25 \%$ e a de anúncios publicitários, os restantes $50 \%$.

De 2003 para 2004, o faturamento dos jornais aumentou 2\% em termos reais, conforme se observa no gráfico 5. Entretanto, o aumento foi muito mais expressivo em todos os outros meios de comunicação, com exceção da revista. $\mathrm{O}$ dado sugere que os anúncios publicitários podem estar se deslocando do jornal para outros meios. As TVs por assinatura foram as que tiveram o maior aumento de faturamento, com $61 \%$. A internet veio em segundo lugar, com $35 \%$. As TVs abertas em terceiro, com $26 \%$. O rádio, em quarto, com $19 \%$. Os jornais em quinto, com $15 \%$, e, por último, as revistas, com $11 \%$ (gráfico 9): 


\section{GRÁFICO 9}

Faturamento bruto anual dos meios de comunicação de todo o Brasil (em $\mathbf{R} \$$ milhões)

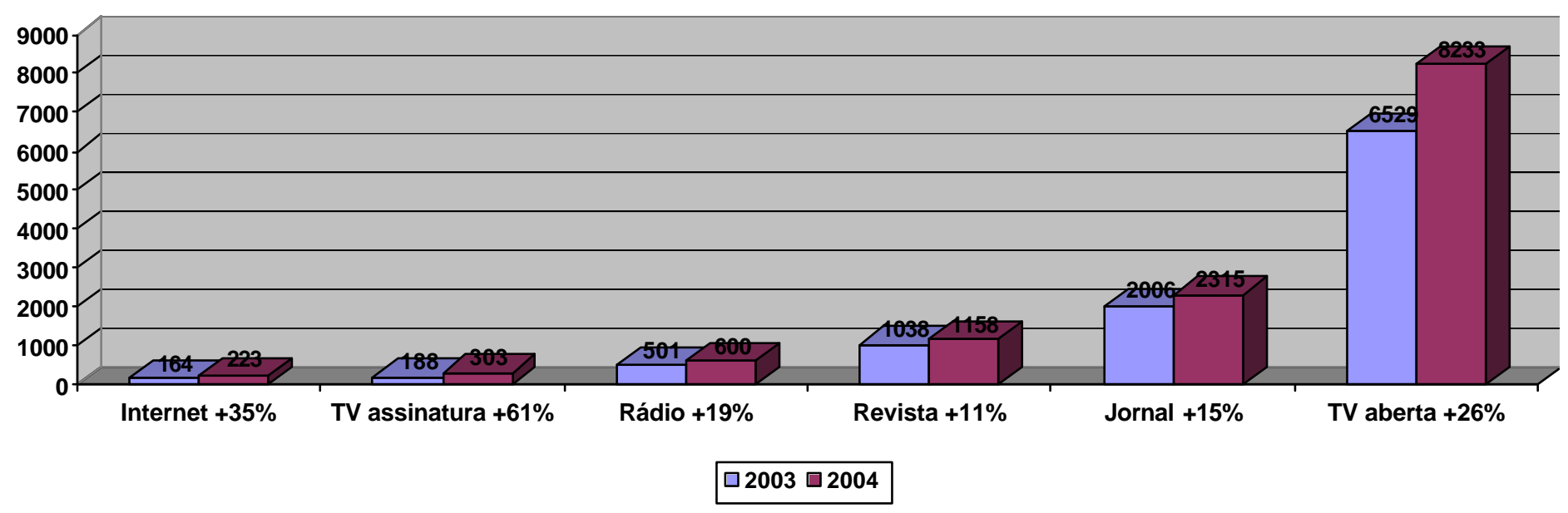

Fonte: Projeto Inter-Meios

Ainda assim, 32\% de toda a verba do mercado anunciante em 2005 foi destinada aos jornais, segundo pesquisa Ibope Monitor para a Associação Nacional de Jornais. (PAULINO, 2006b)

A receita de publicidade por exemplar vendido aumentou 29\% entre 2002 e 2005, em 19 jornais pesquisados pela Associação Nacional de Jornais (DE OLIVEIRA, 2006). De acordo com a pesquisa Indicadores de Gestão Editorial, a receita média de publicidade centimetrada por exemplar vendido subiu de $R \$$ 1,23 em 2002, para $R \$ 1,59$, em 2005.

Desses 19 jornais, 12 são considerados "de qualidade" e outros 7 considerados "populares" ${ }^{27}$. Abrindo-se o dado, observa-se que, nos 12 jornais de qualidade pesquisados, a média é mais alta do que nos 7 jornais populares. Em 2002, a receita de publicidade centimetrada por exemplar vendido nos jornais de qualidade estava, em média, em $R \$ 1,61$. Já em 2005 , essa média foi de $R \$$ 2,01. Entretanto, observa-se que a diferença veio diminuindo nesse período.

\footnotetext{
${ }^{27}$ Os jornais "de qualidade" pesquisados foram: O Globo, Zero Hora, Diário de Santa Maria, O Pioneiro, Jornal de Santa Catarina, Diário Catarinense, Gazeta do Povo, A Gazeta de Vitória, Diário do Grande ABC, A Tribuna de Santos, O Estado de S. Paulo e O Popular; os "populares": Extra, Diário de S. Paulo, Diário Gaúcho, Notícia Agora, Expresso Popular e Jornal da Tarde.
} 
Em 2002, essa receita, entre os jornais populares, era de $R \$ 0,21$, em média ou quase oito vezes menor do que entre os jornais de qualidade. Já em 2005, essa receita média chegou a $R \$ 0,92$ nos jornais populares - pouco menos da metade dos jornais de qualidade.

Isso significa que os jornais de qualidade continuam sendo mais rentáveis do que os jornais populares, na relação entre receita de publicidade e tiragem. Mas os jornais populares têm aumentando essa rentabilidade num ritmo muito mais veloz do que os jornais de qualidade. (OLIVEIRA, 2006)

A pesquisa mede, também, a produtividade dos jornalistas, que ficou praticamente estável no período. A quantidade de páginas de jornal standard editadas por jornalista era, na média dos 19 jornais, de 141 páginas em 2002; aumentou para 142 em 2003; e ficou em 144 páginas por jornalista em 2004 e em 2005.

Como seria de esperar, nos jornais populares, a média de páginas editadas por jornalista é bem maior do que nos jornais de qualidade. Nos 12 jornais considerados de qualidade, a média foi de 131 páginas por jornalista, em 2002 e em 2003; em 2004, aumentou para 135 páginas por jornalista; mas em 2005 voltou para o patamar anterior, de 132 páginas. Já nos 7 jornais populares, a média foi de 161 em 2002; 160 em 2003; 159 em 2004 e 163 em 2005.

A pesquisa revela, também, que não houve, ao longo dos últimos quatro anos, uma mudança expressiva na relação entre o custo das redações e as receitas líquidas. Em 2002, o custo das redações dos 19 jornais representava, em média, 17,2\% das receitas líquidas. Em 2003, essa média subiu para 18,4\%; em 2004, ficou praticamente estável, em 18,5\%; e, em 2005, caiu para $18 \%$.

O custo das redações por página standard editada, na média dos 19 jornais, era de $R \$ 734,50$ em 2002; aumentou para $R \$ 778,10$ em 2003; para $R \$$ 800,10 em 2004; e para $\mathrm{R} \$ 862,50$ em 2005.

A quantidade de exemplares vendidos por funcionário da redação era, na média, de 636,8 exemplares, em 2002; caiu para 518,0, em 2003; subiu para 545,3 , em 2004; e voltou a aumentar em 2005, para 580,5. Essa média é muito menor entre os jornais de qualidade do que entre os populares, o que é coerente com o dado sobre o número de páginas editadas por jornalista. Em 2005, foram vendidos, em média, 376 exemplares dos jornais de qualidade por cada funcionário na redação. Já na média dos jornais populares, no mesmo 
ano de 2005, foram vendidos 908 exemplares por funcionário da redação. Tanto um quanto outro seguem as tendências gerais, de queda entre $2002 \mathrm{e}$ 2003, e recuperação entre 2003 e 2005.

O importante é notar que o período de queda da produtividade coincide com os anos de queda da circulação dos jornais - entre 2002 e 2003. E que o período de aumento da produtividade também coincide com o aumento da circulação entre 2004 e 2005. Daí se infere que essas variações não estão sendo substancialmente causadas por mudanças no número de jornalistas e de funcionários da redação, mas pelas oscilações no número de exemplares.

Em resumo, os jornais aumentaram suas receitas nos últimos anos, embora outros meios as tenham aumentado num ritmo mais intenso. Os jornais de qualidade continuam mais rentáveis que os jornais populares, mas os populares estão aumentando sua rentabilidade muito mais depressa.

A relação entre receitas líquidas e custos da redação, número de jornalistas e de funcionários da redação se tem mantido estável nos últimos anos, considerando a circulação dos jornais. Isso sugere que, pelo menos nos últimos quatro anos, os jornais não aumentaram sua rentabilidade às custas dos investimentos na redação e em seu pessoal.

Como se vê, o jornal se ressente com a queda de leitura e a concorrência de novos meios, notadamente a internet, que reduziram a sua fatia no mercado da informação. Mas, depois de três anos de queda, a sua circulação voltou a aumentar nos últimos dois anos. E seu faturamento aumenta, ainda que não no mesmo ritmo dos outros meios. Não há sinais, no conjunto, de desinvestimento na redação, onde se concentra a atividade-fim dos jornais: não se alterou significativamente, nos últimos anos, a relação entre os custos da redação e as receitas líquidas. As inovações tecnológicas, também assimiladas pelos jornais de papel, não alteraram de modo expressivo a relação entre o número de jornalistas e de funcionários da redação e a tiragem dos jornais.

Em conjunto, todos esses dados indicam que a diminuição na circulação dos jornais, nesta década, foi um fenômeno estrutural, desvinculado do crescimento econômico (macroeconomia) e da economia interna das empresas jornalísticas (microeconomia). Sua causa é a mudança dos hábitos de leitura, e o deslocamento do consumo de informação nos jornais para a internet. 
Vejamos, agora, os critérios de escolha do público-alvo, diante dessa variada cesta de informações.

\section{O ponto de vista da audiência}

O que se passa com os jornais é, em grande medida, o reflexo do que se passa com os seus potenciais leitores. Afinal, por que menos pessoas estão lendo jornal, e por menos tempo? Antes de responder a essa pergunta, examinemos as razões que levam as pessoas a consumir informações, e a escolher, no variado leque que se lhes oferece, o meio ${ }^{28}$ e o veículo nos quais buscá-las.

De acordo com Anthony Downs, o desejo das pessoas por informações atende a quatro funções de sua vida cotidiana: consumo, produção, entretenimento e voto $^{29}$. Um indivíduo decide sobre qual informação consumir, e como, levando em conta uma relação custo-benefício. Entre os custos de adquirir a informação, estão a assinatura de um jornal, revista ou TV paga, ou o tempo gasto assistindo TV ou navegando na internet, observa James T. Hamilton ${ }^{30}$. Mesmo a informação gratuita envolve um custo de oportunidade, de deixar de obter informações por outros meios, naquele lapso de tempo. Uma vez que a atenção de uma pessoa é um bem escasso, ela deve escolher entre tomar decisões com base nas informações que já tem ou buscar mais informações. Nesse caso, os benefícios da informação buscada dependem das chances de essa informação influir na decisão a ser tomada. "Uma pessoa decidindo quanta informação consumir cotejará os custos adicionais associados a ganhar mais uma unidade de informação com os benefícios adicionais de tomar uma decisão mais bem informada", escreve Hamilton.

Acontece que a informação é um bem de experiência, em oposição aos bens de procura. Os bens de experiência são aqueles cuja qualidade e utilidade o consumidor só pode saber depois de consumir. É o caso de uma refeição ou um destino turístico, por exemplo. Em contrapartida, bens de procura podem

\footnotetext{
${ }^{28}$ Adota-se, aqui, o conceito de "meio" empregado usualmente na literatura, conforme definido, por exemplo, por Jaime Alonso e Lourdes Martínez: "Os meios são instrumentos ou formas de comunicação, mediante os quais se transmitem mensagens e informações. (...) Cada meio se distribui através de um canal e um suporte específico (...)." Apud NOCI e SALAVERRÍA, 2003, p. 265.

Apud HAMILTON, 2004, p. 10.

${ }^{30}$ Id.
} 
ter a sua qualidade e utilidade pesquisadas, escrutinadas, antes da decisão da compra. Exemplos: móveis e sapatos. Sendo um bem de experiência, e com o tempo cada vez mais escasso, a notícia requer que o consumidor esteja constantemente atento às relações custo-benefício de sua experiência com os meios de comunicação, e faça uma reflexão constante sobre seus hábitos.

Com o aumento da variedade de meios disponíveis, com as rápidas mudanças tecnológicas, os meios de comunicação não se podem fiar apenas em "hábitos" ou mesmo em sentimentos de "obrigação" por parte dos consumidores. É preciso que eles estejam consta ntemente conquistando seu público.

É o que ilustra pesquisa qualitativa realizada por um grande instituto na cidade de São Paulo, sobre como integrantes das classes A e B+ buscam informações noticiosas. A pesquisa usou o método conhecido como focus group, em que entrevistadores conduzem perguntas a um grupo de pessoas, filmadas e observadas por profissionais que tomam anotações do outro lado de um vidro espelhado. Foi realizada em 2003, com 13 grupos, separados por sexo, faixa etária, faixa de renda ( $A$ e $B+)$, e pelo meio que mais utilizam para se informar: jornal, internet, revista, TV aberta, TV por assinatura e rádio. ${ }^{31} \mathrm{~A}$ condição de buscar informações, rotineiramente, por um desses meios, é o ponto em comum entre todos os entrevistados.

O primeiro dado que transparece das entrevistas é a importância da informação. Conversando livremente sobre o tema, os grupos classificaram a informação de algo "essencial", "necessário", "fundamental", “importante" e "vital". E associaram à informação e aos meios de comunicação sensações de "prazer", "satisfação", "dinamismo", "realismo", "atualidade", "conhecimento", "descoberta" e "aprendizado". Sobre os benefícios que a informação oferece, as expressões mais freqüentes foram: "Ser mais inteligente, ter mais conhecimento, ser mais culto"; "Tornar-se mais criativo, saber ter mais argumentos"; "Poder interagir mais com as pessoas." Acerca do papel social da informação, uma síntese das visões dos entrevistados seria a de que "a notícia e a opinião tornaram-se matérias-primas básicas e o produto mais importante

\footnotetext{
${ }^{31}$ Por razões de sigilo comercial, não poderão ser fornecidos mais detalhes sobre a realização da pesquisa.
} 
da sociedade e da economia atual", sendo que "pela informação o indivíduo constrói seu conhecimento e integra-se à realidade".

Fica demonstrado, portanto, que, de maneira geral, a informação e os meios de comunicação são vistos como algo útil e necessário. O que, de resto, é compatível com 0 senso comum. A valorização da informação, o estabelecimento de uma dependência quase doentia em relação a ela, na sociedade moderna, tem sido esquadrinhada por vários autores, entre eles, Richard Saul Wurman, que escreveu, em seu livro sugestivamente intitulado Information anxiety, em 1989, portanto alguns anos antes de a internet elevar a ubiqüidade da informação a um novo patamar:

Para sobreviver no mercado de trabalho e até para funcionar na sociedade em geral, somos forçados a assimilar um corpo de conhecimento que se expande a cada minuto. Por evidência, pense na pilha sempre crescente de periódicos, livros, brochuras, comunicados do escritório e relatórios anuais que provavelmente está se acumulando no seu escritório esperando para ser lida. A informação se tornou a força motriz de nossas vidas, e a ameaça nefasta dessa pilha sempre crescente demandando que seja entendida deixa a maioria de nós ansiosa." (WURMAN, 1989, p. 32)

"Informação é tudo", disseram integrantes do grupo de homens de 18 a 23 anos, leitores dos jornais O Estado de São Paulo e Folha de São Paulo. "Se você não está bem informado, você não se sente bem. Não dá para conviver com as pessoas." Já para homens da faixa dos 25 aos 40 anos que têm na internet a sua principal fonte de informações, "a informação é fundamental, seja para você conversar com amigos, com o pessoal do trabalho, para você se divertir. Informação hoje é imprescindível. Aonde você vai, você tem que se informar." Homens entre 25 e 40 anos que se informam predominantemente por meio da TV por assinatura disseram: "Se você não tiver informação, você fica alienado. Vivemos num mundo que muda todo dia. Existem muitas informações. Você sempre tem que estar antenado."

Assim, o primeiro ponto estabelecido é o de que, se há perda de interesse pelo jornal, não é por falta de apetite pela notícia e pela informação.

Uma das constatações dos pesquisadores foi a de que os entrevistados não se informam apenas por um meio. Embora haja uma predominância de um dos meios, cada indivíduo "monta" a sua combinação pessoal de fontes de informação, de acordo com cada momento do dia, e até mesmo com cada 
momento de sua vida. Assim, ele é capaz de eleger o meio de comunicação mais importante naquele momento de sua vida, mas interage também com outros meios.

"Você tem que acessar vários veículos", disseram homens de 25 a 40 anos, leitores do Estado e da Folha. "Eu vou pegando os assuntos e vou aprofundando aqueles que me interessam. Eu gosto de ter vários canais para estar me informando. Eu acho que um complementa o outro. Acho que o jornal é o mais completo."

Assim, o segundo ponto a enfatizar é o de que, o que quer que se possa detectar como tendências de comportamento diante dos meios de comunicação, trata-se mais de ênfases e de preferências, do que de escolhas rígidas e definitivas; trata-se de uma relação dinâmica, em vez de estática.

Os pesquisadores observaram uma percepção generalizada de que há "pouco tempo para absorver todas as informações disponíveis e veiculadas" numa velocidade crescente. A falta de tempo e a velocidade do fluxo "acarretam a percepção de que a informação é fragmentada". Daí, observam os pesquisadores, "a necessidade de interagir em maior ou menor grau de intensidade com vários meios de comunicação até consolidarem a informação".

"Eu acho que você tem que acessar vários, porque você tem que ir construindo aquilo que você acha da informação", disseram integrantes do grupo de homens de 25 a 40 anos para os quais as revistas semanais de temas gerais (Veja, Época e Istoé) são a principal fonte de informação. "Você vai fechando o seu quadro de informação. Você vai tecendo aquilo que é importante para você."

"Quando você se fixa num único meio de comunicação, você fica atrasado", disseram homens de 25 a 40 anos, leitores do Jornal da Tarde e do Diário de São Paulo. "Os fatos e a dinâmica da vida são tão intensos que você precisa ver o que cada um oferece. Eles se complementam. Você não tem tempo para ficar absorvendo informação de um único canal. Você vai pegando um pouco de cada."

Entre os leitores de 25 a 40 anos do Estado e da Folha, há uma percepção de que "hoje está tudo tão rápido, tão veloz, a impressão que dá é que a 
informação é fragmentada, mas não é. É você que não tem tempo, às vezes, de absorver, tem que ser aos poucos".

De maneira bastante resumida e esquemática, é possível dizer que os entrevistados encaram cada meio da seguinte forma:

RÁDIO - O rádio propicia uma primeira aproximação da notícia. Funciona como um "filtro", informando quais são os fatos relevantes, para que depois o ouvinte se aprofunde neles, em outros meios. Ele fornece as informações de utilidade prática, sobre trânsito e meteorologia, por exemplo, que no jargão jornalístico se chamam de "serviço". O rádio tem ainda a vantagem de mesclar entretenimento com notícias, o que representa um alívio para a sentida sobrecarga de informações em formato sisudo, que se constatará mais adiante. E é um "companheiro". Entretanto, observam os entrevistadores, resumindo as percepções dos entrevistados, no rádio, "a notícia não tem profundidade", e "há dúvidas em relação à sua credibilidade". Se o ouvinte está desatento, perde a informação, e não tem como recuperá-la, comentaram os entrevistados. Por outro lado, para o ouvinte atento, o meio pode se tornar "cansativo, enfadonho", porque "a mesma notícia é repetida várias vezes". Integrantes do grupo de homens de 25 a 40 anos leitores do Estado e da Folha tiveram suas visões resumidas assim: "Eu acho que no rádio falta mais informação. Como entretenimento é legal, você ficar mesclando, mas eles não conseguem dar uma informação completa. Eu sinto necessidade de ter uma maior amplitude da notícia." Leitores da mesma faixa etária do Jornal da Tarde e do Diário de São Paulo disseram que, no rádio, "a notícia chega de um jeito mais divertido, mais descontraído, mas sempre depois você tem um sentimento de vazio, ou ainda dúvida da notícia que acabou de ouvir."

TV - Os recursos de imagem e de som da TV permitem entender melhor a notícia. Para alguns participantes, "é um meio de comunicação relaxante, descontraído de receber informação", anotaram os pesquisadores. "Para uma parcela da amostra, é o meio 'mais prazeroso'." Mas há também a percepção de que a TV "trabalha com as fantasias, com o mundo não real, com aspirações e ansiedade", e de que o "confronto com a realidade muitas vezes é atenuado ou exacerbado". Há, portanto, uma ambigüidade aqui: de 
um lado, a TV, com seus recursos de imagem e som, parece ser a mais capaz de mostrar o fato como ele aconteceu; de outro, ela parece recriar a realidade, com base em fantasias e desejos de um suposto imaginário coletivo. Um dos adjetivos associados a ela foi "manipuladora". Mulheres de 25 a 40 anos, que se informam predominantemente por meio de revistas semanais de notícias, consideraram a TV "um rádio melhorado, em que você pode ver o que está acontecendo realmente. Ela ganha no visual. É mais fácil de você entender as notícias." Homens na mesma faixa etária, que se informam mais pela TV paga, disseram: "A força dela está na imagem e nas altas produções. Só que ela é muito superficial, não vai a fundo. É muito tendenciosa. Mostra só aquilo que ela quer." No grupo de homens dessa mesma idade, leitores do Estado e da Folha, observou-se que a TV "banaliza as informações. Por ser um meio de massa, ela tem de ser também básica". Segundo os pesquisadores, "os participantes que demonstram maior envolvimento com o jornal" consideraram que 0 confronto com as informações veiculadas por ele revela que "a TV manipula a informação e não agrega nada". Os homens de 25 a 40 anos que se informam predominantemente pela internet externaram uma visão semelhante, chamando a informação da TV de "massificada e superficial". $O$ que é interessante, porque sugere que, assim como o jornal, a internet também tem funcionado como recurso daqueles que exigem mais informação, e melhor. Leitores da mesma faixa etária do JT e do Diário disseram que a TV "é uma forma de dar uma relaxada, descontrair. Você não precisa fazer nenhum esforço, a informação vem até você". Já os participantes que apreciam a TV e têm menos envolvimento com o jornal demonstraram que a TV representa para eles "o momento de compreender de forma didática aquilo que não ficou claro para eles durante o dia, pelas notícias que ouviram no rádio, viram na internet ou ainda foram comentadas por amigos e familiares". Aqueles que têm o hábito de ver a TV logo de manhã - ou de "ouvi-la" apenas, parando para ver só quando alguma notícia chama a atenção - disseram que ela serve de "pauta" para as conversas durante o trajeto até o trabalho e no início do expediente. 
INTERNET - Os participantes da pesquisa qualificaram a internet de um meio "infinito", no qual se obtêm as informações mais atuais de forma "ágil, rápida". É um "banco de dados", uma "janela aberta para obter informações e notícias de qualquer parte do mundo". Ao mesmo tempo em que dá a notícia em "tempo real", disseram os entrevistados, a internet também tem um lado "atemporal", já que por ela é possível "conhecer o passado e o presente" simultaneamente. Mulheres de 25 a 40 anos, leitoras do Estado e da Folha, definiram assim seu entusiasmo: "Internet é um aparelho fantástico, em que você tem o mundo todo ali nas suas mãos. É um meio moderno em que você interage com o mundo inteiro." Na mesma faixa etária e leitores dos mesmos jornais, os homens disseram que ela "é um meio de comunicação em que você não tem limite. Você pode procurar tanto informações do passado quanto as que acabaram de acontecer. Pode falar com uma pessoa do outro lado do mundo. É uma total conectividade com a informação." Homens de 18 a 23 anos que têm na internet sua principal fonte de notícias disseram que ela "é um meio ágil de obter informações atualizadas a todo momento. Na realidade, você não tem só informações, você pode pesquisar o que você quiser". O público mais jovem, de 18 a 23 anos, "tende a ter uma maior relação de proximidade", anotam os pesquisadores. "Muitos efetuam a leitura de títulos de jornais pela internet e dispensam em alguns casos a leitura do jornal impresso. Consideram um meio mais prático e rápido de leitura." Homens dessa faixa etária disseram: "Eu me habituei a ler jornal na internet. Não vejo nenhuma diferença em relação ao jornal impresso. Acho até mais prático. Não suja a mão, não é enorme." Entre os grupos pesquisados, foi quase consenso que em grande parte "o uso da internet se dá no ambiente de trabalho, entre uma tarefa e outra". Alguns entrevistados disseram que a internet é um meio mais adequado para se ler no ambiente de trabalho do que o jornal impresso. Abrir o jornal nesse ambiente é complicado: dá impressão de ócio. Em contrapartida, a atitude de ler na tela de computador - mesmo que o conteúdo não seja o do trabalho - é mais discreta. "No meu trabalho, não dá para ler jornal logo no início do dia ou em qualquer outro momento", disseram integrantes do grupo de homens de 25 a 40 anos que se informam mais pela TV por assinatura. "A impressão que dá é que você não está 
tendo nada para fazer. Eu sempre acompanho as notícias na internet. Às vezes, ouço a notícia no rádio, chego no trabalho e já abro a internet." Homens de 25 a 40 anos que se informam predominantemente pelas revistas semanais declararam: "Eu sempre vejo notícia pela internet no meu trabalho. Em casa, não gosto muito de ver, mas, no trabalho, é direto. Entre uma tarefa e outra, você dá uma olhadinha para ver o que está acontecendo." Nessa mesma faixa, os leitores do Estado e da Folha disseram: "Acho que a maior parte do tempo que eu estou na internet é no momento que estou no escritório. Eu tenho que estar acompanhando o mercado, o que está acontecendo. A internet traz essa informação atualizada de forma quase instantânea." Os pesquisadores observaram que a internet proporciona "uma certa sensação de poder, de domínio sobre a informação". Nesse sentido, os participantes elogiaram o fato de que na internet "não há imposição de idéias, você tem liberdade para procurar o que você quiser e interagir com a informação". Disseram também que ela possibilita "contato com vários aspectos e enfoques de uma mesma idéia". E apontaram os recursos de imagem e do som, que, como no caso da TV, "facilitam a apreensão da informação". Entretanto, queixaram-se de que falta "confiabilidade" à internet, e "qualidade" à notícia que ela veicula. "Por ser rápida, ela não é tão aprofundada", disseram homens de 25 a 40 anos, leitores de revistas. "As notícias são menos trabalhadas. Tem muita coisa que você fica em dúvida se confia mesmo na informação." Mulheres da mesma faixa etária e também leitoras de revistas disseram: "Você tem que complementar depois com a notícia de jornal. Por exemplo, na internet você fica sabendo que um avião caiu. No jornal, você fica sabendo por que ele caiu, os detalhes do acontecimento." Homens também de 25 a 40 anos, mas que se informam predominantemente pela internet, admitiram: "A internet te atualiza mas não dá a profundidade que um jornal tem. Não dá tempo, até mesmo porque ela coloca a notícia pra você quase em tempo real. Por isso, muitas vezes, você fica em dúvida: será que é isso mesmo? Eu sempre checo e vou atrás de mais informações no jornal." Leitores do Estado e da Folha, na mesma faixa etária, afirmaram: "Na internet, eu fico com um sentimento de que a notícia é descartável. É um rádio visual. Você vê a notícia, mas, no dia seguinte, nada como um bom e velho jornal para 
você saber tudo de forma mais completa." Os participantes também detectam uma "dispersão" na internet, em face da "infinidade" de informações. Com isso, perde-se o "foco" da informação. "Às vezes, até complica, de tanta informação que você tem", disseram homens de 25 a 40 anos, leitores do JT e do Diário. "Você acaba se perdendo dentro da internet. Você entra para ver uma informação, quando vê já está dentro de outro site, de outro assunto. Muitas vezes, tem um excesso de informação que você não tem como peneirar." Eles também consideram "incômodo e cansativo" ter de abrir várias janelas até se chegar à informação buscada. "A linguagem é simples, mas eu acho cansativo ficar lendo notícia na tela do computador. Eu não gosto, acho que cansa muito, me incomoda", disseram homens leitores do Estado e da Folha, entre 25 e 40 anos. "Tem também a questão de você ter que ficar abrindo janelas para chegar aonde você quer. Às vezes, acho muito mais rápido pegar o jornal." Em síntese, de acordo com os pesquisadores, na visão dos entrevistados em geral, a internet é "globalizada, ágil, essencial, fonte de dados, dinâmica, atual, interativa, resumida, jovem, didática, vasta e infinita"; em contrapartida, ela não é "profunda, crível, cultural, 100\% perfeita, segura, barata, suficiente e fácil de manusear e encontrar o que se quer". Os sentimentos dos entrevistados depois de terem visto uma notícia na internet são resumidos nas seguintes expressões:

> "Tenho que complementar a informação."

$>$ "Cadê a fonte da notícia?"

> "Será que é verdade?"

> "Notícia descartável."

> "Vício."

> "Quero mais!"

REVISTA - Os participantes em geral definiram a revista de informação semanal (Veja, Época, Istoé, Carta Capital) assim: "forma mais prazerosa e leve de ter a notícia, a informação"; um "álbum fotográfico"; "resumo das notícias da semana, com a matéria de capa aprofundada"; uma "maneira elitista de obter a informação"; "conta histórias de forma prática e didática"; 
"você pode levar para onde quiser"; "oferece liberdade de leitura na hora em que the convier". Os leitores de banca informaram que compram revistas ocasionalmente, quando se sentem atraídos pela capa, e que não as adquirem com mais freqüência por causa do custo elevado. Já os assinantes disseram que nem sempre lêem as revistas nos fins de semana. Em geral, costumam folhear toda a revista e ler a entrevista principal, deixando as outras matérias para ler no decorrer da semana, "entre uma atividade e outra, quando há um tempo disponível". Tanto entre os homens quanto entre as mulheres, os pesquisadores observaram que "a revista é uma forma mais 'light' e descompromissada de obter a notícia", proporcionando 'uma sensação de 'descanso', de 'relax', uma 'pausa' da linguagem jornalística que exige maior concentração e raciocínio". Os pesquisadores apontam para o fato de que "algumas mulheres preferem ler a revista também durante a semana, em vez de ler jornal", porque "não apreciam a linguagem 'rebuscada" do jornal. "Quando lêem jornal, a preferência maior tende a ser por seções de entretenimento: horóscopo, caderno de turismo, programações culturais". Na opinião de homens de 25 a 40 anos, leitores do JT e do Diário, "revista é mais resumida e ao mesmo tempo mais elitista que jornal. Na revista, você tem uma matéria que é mais aprofundada. É como se você pegasse uma enciclopédia. Ela tem mais tempo de trabalhar a informação." As mulheres da mesma faixa etária, leitoras de revistas, disseram que "ela resume todas as notícias da semana. É mais gostosa de ler, mais limpa, mais colorida. Tem um visual mais atrativo." Homens dessa faixa etária, leitores do Estado e da Folha, foram na mesma linha: "É uma leitura que você curte. A linguagem é bem mais leve que a linguagem do jornal. Às vezes, você quer dar uma refrescada na cabeça, principalmente no fim de semana." Os leitores elogiaram o formato, o papel e a linguagem da revista. É "portátil", "prática", "não suja as mãos", contém "fotos atrativas e ilustrativas que facilitam a apreensão do contexto da notícia". Sua linguagem é "mais simples e didática", além de oferecer uma matéria principal "bem aprofundada". Para os entrevistados, a revista tem mais qualidade e profundidade que 0 jornal. Eles se queixaram, no entanto, do preço; de "certa manipulação" em algumas revistas; do espaço excessivo dedicado a anúncios; da falta de atualidade; e de uma certa 
redundância. "Às vezes, a revista gasta três páginas só para mostrar as pessoas mortas, e fala uma página só sobre a guerra", observaram integrantes do grupo de homens de 18 a 23 anos, que se informam predominantemente pela internet. "Você paga uma grana, às vezes, para ter uma revista cheia de anúncios ou ainda eles ficam enrolando para chegar ao ' $x$ ' da questão." Na visão dos entrevistados, a revista é "companheira, resumida, condensada, ilustrada, prazerosa, fácil de entender e manusear, e agradável". Em contrapartida, ela não é "barata, para qualquer pessoa (em razão do preço), abrangente, atual, novidade". Leitores do Estado e da Folha, de 25 a 40 anos, disseram: "Quando eu termino de ler a revista, me sinto informado. Principalmente em relação à matéria principal, parece que eu aprendi mais." Além disso, segundo eles, "é uma leitura que você curte. A linguagem é bem mais leve que a linguagem do jornal. Às vezes, você quer dar uma refrescada na cabeça, principalmente no fim de semana." Para mulheres de 25 a 40 anos leitoras de revistas, "ela resume todas as notícias da semana. É mais gostosa de ler, mais limpa, mais colorida. Tem um visual mais atrativo."

JORNAL - Os entrevistados definiram o jornal como o "meio de comunicação mais completo, o que vai mais fundo, o que é investigativo", e o que "estimula a pensar". Disseram que ele "documenta" os fatos, e elogiaram seu formato portátil, que permite escolher como e onde ler. "Mesmo entre os participantes que demonstram um menor envolvimento com o jornal, há um pronto reconhecimento de que ele desfaz as incertezas do receptor diante de várias alternativas de uma mesma notícia", escreveram os pesquisadores. "Usuários de meios como internet, revistas e rádio apreciam a leitura de jornal, mesmo que esporádica." Os homens de 25 a 40 anos que se informam predominantemente pela internet disseram: "Jornal é o informativo que traz as notícias do dia. Eu considero que seja o meio mais completo. Quando você desconfia de alguma coisa, pode olhar no jornal, que é o meio que te dá a garantia de você ter uma informação de credibilidade." Leitores da mesma faixa etária do JT e do Diário afirmaram: "É mais abrangente. Ele documenta historicamente os fatos. A informação fica registrada. Você pode arquivar." Homens de 18 a 23 anos, leitores do 
Estado e da Folha, declararam: "Você pode ler a notícia que você quiser na hora que quiser. Tem uma diversidade de assuntos. Ensina você a pensar, a ter uma visão mais crítica da sociedade." Os pesquisadores ressaltam que na amostra se definem perfis bastante diferenciados quanto à leitura do jornal, e que "o jornal parece ser um território mais 'masculino' do que 'feminino'”. Assim, entre os participantes que demonstram ter maior envolvimento com o jornal, "há uma maior preocupação em obter a informação através dele pela credibilidade que oferece, versus outros meios". Nesse grupo, a leitura do jornal tende a acontecer quase que diariamente, seja ela de manhã, antes de iniciar as tarefas, no ambiente de trabalho, na hora do almoço, etc. E a tendência inicial é sempre ler as matérias principais, em destaque. "Para mim, o jornal é o meio mais confiável", disseram homens de 25 a 40 anos, que se informam predominantemente por revistas semanais. "É chato de ler, mas é aquele em que você encontra toda a informação, os detalhes que às vezes outros meios de comunicação não te dão." Homens da mesma faixa etária, que se informam pelas TVs por assinatura, disseram: "Eu sempre começo pelas matérias que têm maior destaque e depois vou lendo aos poucos, nos intervalos que tenho durante o dia." Os participantes cujo envolvimento com o jornal é classificado como médio o lêem de uma a duas vezes por semana, e de forma superficial. Ninguém lê todo o jornal, só algumas notícias que tiveram maior destaque na primeira página. "Há menções sobre a dificuldade de leitura em razão da forma como a notícia é escrita", anotaram os pesquisadores. "A linguagem é considerada 'pesada'." No grupo de homens de 25 a 40 anos que se informam pela TV por assinatura, foi dito: "Com o tempo que a gente tem hoje, quando tudo é corrido, eu não leio todo o jornal. Eu só leio a notícia que tem um maior destaque na página inicial e mais alguma outra coisa que me chama a atenção." Homens da mesma faixa etária, que se informam predominantemente pelo rádio, explicaram: "Na realidade, o que eu faço quando chego no meu trabalho é dar uma olhada por cima. Não paro para ler uma matéria mais aprofundada. É mais dar aquele sobrevôo sobre o jornal." E, no grupo dos leitores de revistas: "Eu não gosto muito de ler jornal. Leio mais por obrigação mesmo. A vida atual exige isso de você. A linguagem utilizada no jornal não estimula 
você a ter um maior contato. É muito pesada, às vezes você não entende o que quer dizer de forma mais objetiva." Entre os participantes com menor envolvimento, "a leitura se dá diante de uma busca específica de algum tema que sinta necessidade ou que the foi solicitada a informação", escreveram os pesquisadores. Nesse caso, "a leitura ocorre de forma bem esporádica". Para esses leitores eventuais, o jornal é considerado "sério, austero", possui uma "linguagem mais trabalhada, mas em muitos casos difícil de entender". Na sua avaliação, a profusão de cadernos nos jornais configura um "desperdício". Nesse grupo de participantes com o menor envolvimento com o jornal estão incluídas as mulheres. Elas consideram a leitura do jornal "maçante, cansativa". Quando têm o hábito de leitura, a tendência é ir às seções de horóscopo, resumo das novelas, cadernos de cultura e de turismo. E pedem um jornal "mais descontraído, mais leve". Mulheres de 25 a 40 anos que se informam predominantemente pelas revistas disseram: "Quando eu pego o jornal para ler, é mais para fazer palavras cruzadas, ver o horóscopo, o que vai acontecer na novela. Jornal é uma coisa muito chata de ler." Homens da mesma faixa etária, que se informam mais pela TV, afirmaram: "Eu olho o jornal quando eu preciso vender ou comprar alguma coisa, aí eu compro para dar uma olhada nos classificados. De outra forma, não vejo. Quando leio, eu me sinto meio burro. Tem muitas palavras que eu nem sei o que é. Já fiz um esforço, mas prefiro a TV." Nos fins de semana, até entre os leitores com maior envolvimento com o jornal, a tendência é fazer uma "pausa", observaram os pesquisadores. Eles consideram que o jornal não é compatível com o momento de descontração, de "relax", que representa o fim de semana. "Muitos comentam que o jornal traz assuntos muito sérios", e que "sua linguagem exige raciocínio". Sua tendência no fim de semana, quando estão em casa, é ler revista e assistir televisão. "Você lê jornal a semana inteira, chega no domingo, você olha aquele calhamaço de papel", disseram homens de 25 a 40 anos leitores do Estado e da Folha. "Eu vou dar uma volta e dar uma espairecida. Não acho nada divertido ler jornal aos domingos." Homens da mesma faixa etária leitores de revistas enfatizaram o caráter de obrigação da leitura dos jornais: "No fim de semana, o que você quer é sair dessa cidade que é um inferno. Eu não leio jornal aos 
domingos. No sábado eu até leio, mas no domingo eu me dou o direito de não ler jornal. É uma linguagem muito pesada." Assim, ler jornal é um dever; não ler, um direito. Em alguns casos, anotam os pesquisadores, o comportamento se inverte entre leitores com menor envolvimento com o jornal. "Alguns apreciam ler o jornal nos fins de semana por terem maior tempo disponível para a leitura." Mas são casos isolados. "Eu não leio no meio da semana, mas curto ler no fim de semana", disseram homens de 25 a 40 anos, que se informam pela TV por assinatura. "É o dia que eu vou ter mais tempo para ler tranqüilamente. Eu dou uma passada por todos os cadernos. Eu curto ler mais jornal no fim de semana do que durante a semana." As vantagens do jornal foram resumidas assim pelos pesquisadores, com base nas reações dos entrevistados:

Aprofunda a notícia e traz detalhes que os demais meios não elucidam.

Vai atrás da verdade, é investigativo.

> Reúne, num único meio, informações diversas (graças aos cadernos).

$>$ Auxilia o leitor a formar uma opinião, a ter uma visão mais crítica da realidade.

> Tem nome e sobrenome - pessoas de peso, articulistas que assinam as matérias.

> Deixa claro quem é a fonte da informação.

$>$ Transmite maior credibilidade.

$>$ É portátil.

Em contrapartida, foram apontadas as seguintes desvantagens:

> Pelo seu tamanho e formato, é desconfortável de manusear.

> Solta tinta na mão, o papel é considerado "sujo".

> A impressão continua de baixa qualidade, com muitas fotos sem nitidez, mesmo depois da introdução da cor.

> A tipologia é "ultrapassada", dificulta a leitura. 
A linguagem de alguns jornais é "rebuscada, difícil de entender".

> Uma parcela dos participantes identifica posicionamentos ideológicos nos grandes jornais, definindo uns como "de direita" e outros como "de esquerda".

Mais adiante, quando se aprofundaram sobre a imagem de cada jornal, os pesquisadores constataram que os leitores do Estado e da Folha apreciam o que percebem como "posicionamentos polarizados", acreditando que essa polarização lhes permite ter uma "visão mais crítica, e não somente um lado da moeda", e contribui para construírem sua própria opinião. Eles consideram também que cada título pertence a uma determinada "fase da vida", entre a contestação e a estabilidade, por exemplo. E que cada jornal "cumpre um papel ideológico e social".

$\mathrm{Na}$ síntese das qualidades atribuídas ao jornal, os pesquisadores anotaram que ele é "completo, detalhado, informativo, diversificado, primordial, crível, formador de opinião, popular, às vezes chato, redundante, difícil de entender". O jornal não é "confortável e prático de ler, limpo, bonito, falso, duvidoso, dispensável, uma perda de tempo, atualizado instantaneamente, barato". Quanto aos sentimentos após ter obtido a informação através do jornal, eles são de: "responsabilidade, satisfação, ter fechado um círculo, maior conhecimento, enriquecer o vocabulário, aprender a pensar, ser mais inteligente, chatice, cansaço". Palavras que sintetizam o jornal: "credibilidade, tradição, completude, diversidade, seriedade, segurança e maçante". O cansaço e o aspecto maçante foram salientados pelos usuários de TV e pelas mulheres leitoras de revistas. "Depois de ler o jornal, eu me sinto satisfeito porque sei qual é a fonte da informação, sei da credibilidade da informação", disseram homens de 25 a 40 anos, que se informam predominantemente pela internet. "É como eu completo o ciclo. Às vezes, você ouve uma série de informações, quando você olha no jornal, você valida e abrange o seu conhecimento a respeito daquela informação." Já participantes do grupo de homens de 25 a 40 anos que se informam mais pelo rádio se expressaram assim: "Para mim, o sentimento que fica depois de ler jornal é que aprendi mais. Absorvi novas palavras, coloquei o meu pensamento em ação. Refleti sobre algum tema em questão. Jornal é chato de ler, mas é educativo." Os 
participantes se dividiram quanto ao futuro dos meios de comunicação. Uma parte aposta na convergência dos meios na internet, e outra acha que os meios seguirão existindo em separado. De maneira geral, no entanto, assinalaram que o jornal terá cada vez menos leitores, se não houver mudanças na forma como a notícia é redigida, no formato, tamanho, papel, tipologia; se não forem inseridos maiores atrativos como imagens, ilustrações, gráficos que facilitem a assimilação da notícia e sua contextualização; e se ele não ganhar um caráter mais descontraído, sem perder a identidade e a credibilidade.

Os pesquisadores utilizaram também uma técnica para entender o que cada meio representa na vida dos participantes, perguntando com que meio ficariam, se só pudessem escolher um deles. Houve uma grande diversidade de respostas. Mas a maior parte escolheu a internet. Outras parcelas ficaram com o rádio, a revista e a TV. E o jornal foi escolhido pela menor parcela de todas. Depois que cada grupo escolheu o seu meio único hipotético, os pesquisadores pediram que eles o comparassem com o jornal. O resultado foi o seguinte:

$>$ Por que escolher a internet?

- Teria maior interatividade com as pessoas, com a notícia.

- Poderia mandar e-mails, buscar informações de todos os lugares do mundo, ter uma infinidade de informações.

- Ver a notícia e ter entretenimento ao mesmo tempo: games, filmes, música, etc.

$<$ Caso escolhesse o jornal...

- Com certeza estaria mais apto a argumentar e interagir com as outras pessoas.

- Teria mais tempo de "degustar" todo o jornal diariamente, mas não teria as informações atualizadas sobre o que acontecesse durante o dia.

- Depois de um tempo, se tornaria maçante, cansativo, e se sentiria muito solitário.

- Após ter lido o jornal, não teria mais notícia: "O jornal esgota-se".

$>$ Por que escolher o rádio? 
- Adoraria ficar ouvindo música, olhando o mar e ouvindo de vez em quando a notícia, mesmo que fosse só manchete. Seria uma informação superficial, mas atual.

- Teria que ter uma "voz" para agüentar a solidão.

- O rádio seria o seu companheiro.

- Ativaria sua imaginação, quando anunciasse uma notícia.

$<$ Caso escolhesse o jornal...

- O sentimento é de incômodo, desconforto, principalmente por não ter a música, que proporciona entretenimento, e a voz das pessoas.

- Ficaria angustiado, mas com certeza melhor informado.

- Teria um vocabulário mais rico.

$>$ Por que escolher a TV?

- Teria a seu dispor imagem e som.

- Teria notícia e entretenimento.

- O tempo passaria mais rápido e a solidão não seria tão sentida ou dolorida.

$<$ Caso escolhesse o jornal...

- Teria mais tempo para leitura.

- Teria que ter um dicionário para entender algumas palavras.

- Teria a notícia mais aprofundada, o contexto todo da notícia.

- Ficaria mais inteligente, mas talvez "chato".

- Perderia a imagem e o som.

Por que escolher a revista?

- Leria bem devagar durante a semana, ao fim da tarde, em momentos relaxantes.

- Levaria a revista consigo em viagens. (Alguns mencionam que sempre quando viajam costumam comprar diversos títulos de revistas para ler e não têm contato com outros meios de comunicação.)

$<$ Caso escolhesse o jornal... 
- Teria a notícia atualizada diariamente.

- Não precisaria esperar o fim de semana para saber o que está acontecendo no mundo.

- Não teria o mesmo prazer que ao ler a revista.

$>$ Por que escolher o jornal?

- Teria maior tempo para dedicar à leitura do jornal todo.

- Estaria apto a comunicar-se com pessoas de níveis intelectuais mais elevados.

- Teria maior poder de argumentação e maior bagagem cultural.

Dessa pesquisa qualitativa, o jornal emerge mais como obrigação do que como prazer. Com tantas outras opções de fontes de informação, com tantas atribulações e dissabores do dia-a-dia, com o trabalho e o trânsito tomando cada vez mais tempo, não admira que o público busque refúgio em meios de comunicação mais "amigáveis", que ofereçam mais e exijam menos.

Não há escolhas rígidas por parte do público. Ele vai pragmaticamente selecionando, da cesta informativa, o meio que mais lhe convém a cada momento do seu dia-a-dia.

O leitor identifica o jornal com atributos vitais, como a credibilidade. Aqui, o dado da pesquisa qualitativa é consistente com o de uma pesquisa quantitativa intitulada "Confiança nas Instituições", realizada em maio de 2005. Segundo essa pesquisa, os jornais têm a confiança de $74 \%$ da população brasileira, ficando atrás apenas dos médicos e das Forças Armadas. E à frente de todos os outros meios. O rádio obteve a confiança de $64 \%$ dos entrevistados e a televisão, de 61\% (PAULINO, 2006b).

Outro atributo vital é a possibilidade de compreender efetivamente o que se passa ao seu redor. O jornal é definido como o "o mais completo" - o que não é pouca coisa.

O suporte de papel recebe um alento, com o elogio à sua portabilidade, à possibilidade de lê-lo onde e quando quiser - numa clara vantagem em relação à internet, à TV e até ao rádio, todos dependentes de aparelhos. 
Aparentemente, rão há nada de mortal no jornal, que o inviabilize como meio nesse novo ambiente de múltiplas escolhas. O que os entrevistados estão pedindo é que ele seja mais acessível, menos pesado e sisudo; que, além de cumprir a obrigação de se manter informado, o leitor encontre no jornal também prazer de ler, de ver e de manusear um objeto gráfico agradável e amigável.

Boa parte dessa audiência, aquela que poderia ser considerada, estritamente, como o "público-alvo" do jornal, não se saciaria plenamente apenas com a internet, a televisão e o rádio, por sua superficialidade; nem apenas com as revistas semanais, por sua periodicidade, que as impede de noticiar e interpretar os fatos algumas horas depois de eles ocorrerem, como faz o jornal. Assim, o jornal parece ter assegurado o seu lugar, desde que faça algumas concessões ao prazer do leitor, e não siga comportando-se como se ele fosse obrigado a digeri-lo. Em que medida os jornais podem ou querem fazer essas concessões, é algo que veremos no capítulo 6, que traz a visão dos diretores de redação dos três principais jornais do país. Quanto às revistas semanais, há muito que pesquisas como a que acabamos de relatar vêm orientando suas decisões editoriais. É o que mostra o próximo item.

\section{Índice de qualidade editorial}

Nos últimos dez anos, a Editora Abril, líder do segmento de revistas no Brasil, tem realizado mudanças em seus produtos com base nos resultados de pesquisas qualitativas. Em 1996, o grupo criou um índice de qualidade editorial (IQE), para monitorar o grau de satisfação dos públicos-alvo com suas revistas, acompanhado de uma descrição sistemática dos motivos dessa satisfação ou insatisfação. As pesquisas qualitativas coletam a opinião dos leitores acerca de matérias e de seções das revistas, por meio de entrevistas individuais. Dessas coletas de dados resulta o IQE, que se destina a medir:

1. a atração à leitura, como resultado do desenho gráfico, da pauta e da capa da revista;

2. o porcentual de leitura, que resulta num índice de leitura;

3. o grau de satisfação com o enfoque dado pela matéria, com a edição como um todo e com o atendimento ou não das expectativas. 
Aline Cabral, da Editora Abril, relata um caso em que um título do grupo, identificado apenas como "Revista A", mantinha um "índice de leitura relativamente baixo em seis edições consecutivas". "De forma coerente, havia indicações de fragilidade nos fatores de atração de leitura". Foram implementadas mudanças na edição de maio de 2004, que foram bem recebidas pelos leitores. $O$ resultado foi o aumento significativo do índice de leitura. (CABRAL, 2006) É o que mostra o gráfico 7.

\section{GRÁFICO $10^{32}$ - Evolução dos índices de leitura da "Revista A"}

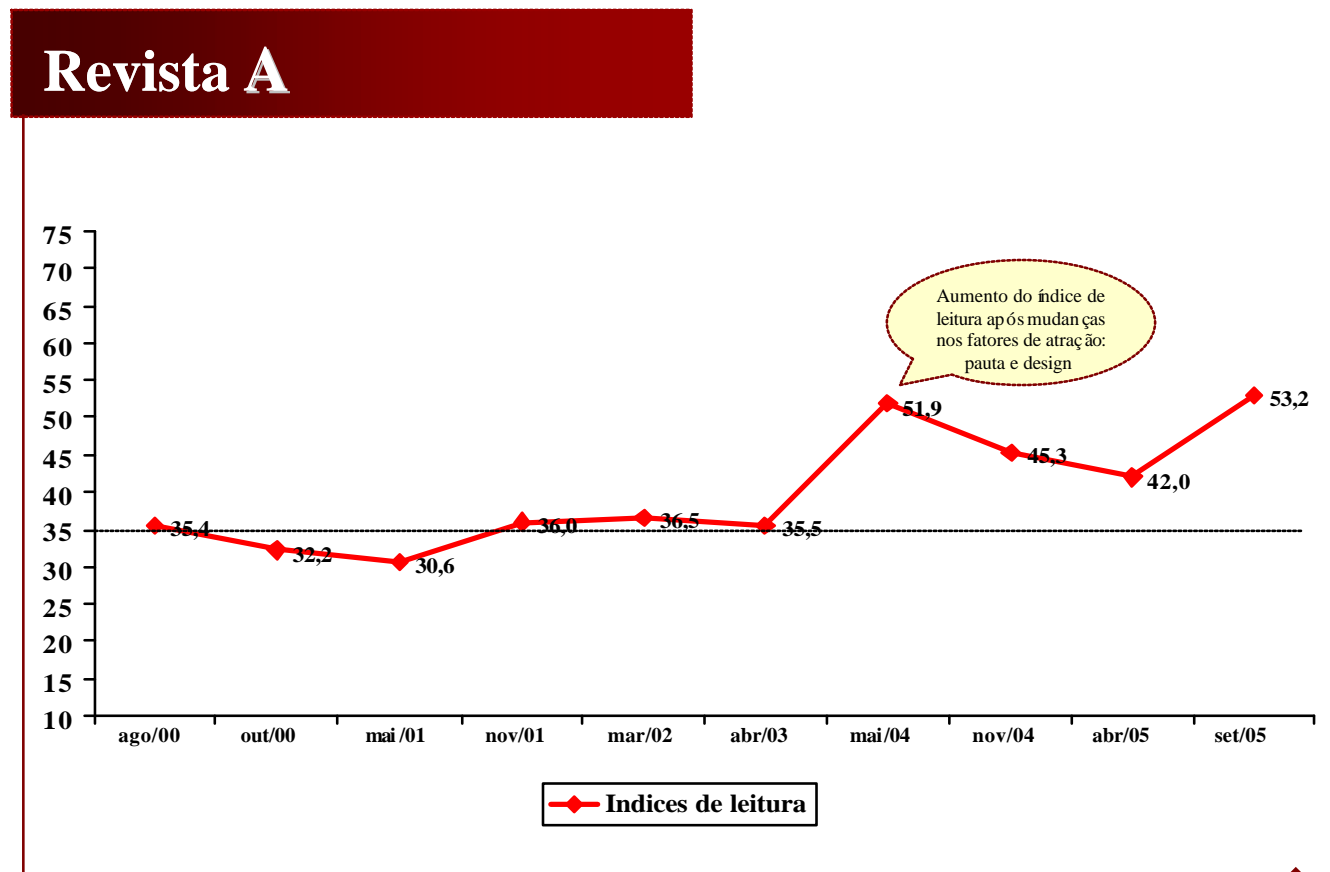

O balão sobre maio de 2004 indica o "aumento do índice de leitura após mudanças nos fatores de atração, pauta e design". O índice de leitura, uma média ponderada sobre o que poderia ter sido lido, vinha em um patamar de cerca de 35 pontos, antes das mudanças. Depois delas, esse índice saltou para os 52 pontos; voltou a cair até 42 , mas subiu novamente, para 53 .

É um exemplo de como as revistas têm lidado com as expectativas do leitor. Sua estratégia é visível nas bancas, com capas sobre saúde, dietas de emagrecimento, comportamento e outros temas que afetam diretamente os leitores na sua vida cotidiana.

\footnotetext{
${ }^{32}$ Gráfico extraído de CABRAL,2006.
} 
Esses temas ocuparam o lugar de destaque antes conferido a assuntos mais áridos, como política e economia. Mas as revistas semanais de informação geral não abandonaram completamente esses temas. É preciso reconhecer seu papel, por exemplo, na cobertura dos escândalos de corrupção dos últimos anos. O primeiro escândalo do governo Lula, a filmagem do ex-funcionário da Casa Civil Waldomiro Diniz oferecendo propina a um empresário do jogo do bicho, foi um furo de reportagem da revista Época, em 2004. A revista Veja publicou furos de reportagem importantes ao longo de 2005 e 2006, na cobertura dos escândalos de corrupção envolvendo o governo Lula.

Em 2006, a revista Veja se assentava sobre uma sólida circulação média semanal de 1,089 milhão de exemplares, que a torna uma das maiores revistas semanais do mundo. A revista Época seguia em segundo lugar, com 433 mil exemplares. E a Istoé em terceiro, com 343 mil. $^{33}$

Não se trata, aqui, de defender a transposição da fórmula das revistas para os jornais: são dois produtos muito diferentes. Mas apenas de ressaltar que elas têm sido bem-sucedidas em combinar o atendimento das demandas do leitor por temas de interesse individual com as demandas do jornalismo por apurações de interesse coletivo.

\section{Atendimento de demandas}

Que diretor de redação não gostaria de dar ao seu leitor o luxuoso suplemento sobre, digamos, gastronomia, que ele pediu? ${ }^{34}$ É evidente que, em grande medida, o atendimento das expectativas dos leitores - que são extremamente variadas - pelos jornais está vinculado a custos. Do grande universo de perfis que compõe o público leitor do jornal, como se vê na pesquisa de focus group que relatamos, resulta uma enorme gama de preferências e demandas por cadernos especiais, suplementos, colunas, coberturas, serviços, índices e outros produtos. A capacidade dos jornais de atender a essas demandas é obviamente finita.

\footnotetext{
${ }^{33}$ Dados do Instituto Verificador de Circulação, publicados na revista Imprensa, ํㅡㄴ 218, de novembro de 2006, p. 78.

${ }^{34}$ Preferimos citar, aqui, uma demanda efetivamente atendida, pelo Estado, por meio de seu premiado caderno Paladar, lançado em 22/9/2005.
} 
Não é necessário que atendimento das demandas resulte em bons resultados financeiros. A empresa, como um todo, precisa sopesar a relação custobenefício de cada projeto, para assegurar a sua saúde financeira. Há, entre suas diversas áreas - comercial, circulação, industrial e redação discrepâncias sobre como medir a relação entre investimentos em qualidade e em atendimento de demandas do leitor, de um lado, e rentabilidade, de outro. Para se chegar a um consenso, entre as diversas áreas da empresa que publica o jornal, sobre a conveniência e viabilidade de um projeto, é preciso coincidir sobre critérios de decisão. $E$ isso não é simples. Em geral, os critérios usados pela redação são subjetivos, produtos da cultura do jornalismo. Não que todos os critérios das áreas comercial, de circulação e industrial sejam objetivos. Elas também têm as suas culturas. Mas é da natureza de seu trabalho a conversão de raciocínios em números, que alimentam planilhas de contabilidade. Já os jornalistas partem de raciocínios semelhantes aos dos potenciais leitores, elencados nos resultados da pesquisa focus group. Com um complicador: os desejos e expectativas dos jornalistas são diferentes daqueles dos leitores.

A seguir, procuraremos esquadrinhar os conceitos e tendências que norteiam esses intrincados processos de tomada de decisões. 


\section{CAPÍTULO 2 - CONCEITOS E TENDÊNCIAS}

Neste capítulo, vamos buscar na literatura reflexões sobre os múltiplos fatores que envolvem o impacto, sobre os jornais, da concorrência, das inovações tecnológicas e das mudanças nos hábitos de leitura. Também discutiremos questões intrínsecas à sua economia interna, que explicam a sua reação a esses desafios - entre elas, as mudanças nos modelos de propriedade e de gestão das empresas jornalísticas. E os elementos para o debate sobre a relação entre qualidade e lucratividade.

No primeiro item, faremos uma breve discussão sobre os conceitos que envolvem as motivações dos leitores, começando por um dado aparentemente paradoxal: cai a circulação dos jornais, como um todo, mas aumenta o número de títulos. A partir desse dado, faremos uma discussão sobre a tendência ao localismo e à segmentação, e seus reflexos sobre a economia dos jornais.

Depois de falar das motivações dos leitores, falaremos das motivações, não menos importantes, dos anunciantes. A publicidade, que responde, em média, por $75 \%$ das receitas dos jornais, também se move por conceitos e tendências, que procuraremos prospectar, com base na literatura, para tentar compreender sua influência sobre as decisões dos jornais, e também as opções que o mercado Ihes reserva.

No terceiro item, buscaremos os elementos que compõem o debate crucial sobre a relação custo-benefício dos diversos produtos que podem ser oferecidos pelo jornal. Diante do alto grau de subjetividade na interpretação das relações causais entre qualidade e rentabilidade, a tentativa de definição de parâmetros não é um esforço trivial nem conduz a conclusões rígidas e definitivas.

O item seguinte é dedicado à descrição da natureza dessa subjetividade: os valores intangíveis envolvidos no conceito de "qualidade" do jornal, que permeiam grande parte das decisões de uma empresa jornalística.

No quinto item, descreveremos as transformações por que passa a gestão das empresas jornalísticas, que saiu do modelo tradicional familiar em direção ao modelo das companhias de capital aberto, passando pela profissionalização da 
gestão - um estágio transitório, no qual dois dos três jornais brasileiros que são objeto deste estudo se encontram neste momento: o Estado e o Globo.

A seguir, exporemos tentativas, descritas na literatura, de criar modelos de aferição dos valores intangíveis, que podem servir de ferramentas gerenciais aos diretores de redação, no seu diálogo cotidiano com as outras áreas do jornal.

O sétimo item discutirá as mudanças de paradigmas nas posições de mercado, nas margens de lucratividade e na cultura empresarial dos jornais. Novos paradigmas devem orientar a reação dos jornais aos desafios impostos pelas inovações tecnológicas, pelo acirramento da concorrência e pelas mudanças nos hábitos de leitura - o tripé deste estudo.

\section{Motivações dos leitores}

Como vimos, o número de títulos de jornais no Brasil está crescendo. De 491, em 2001, saltou para 535, em 2005 - um aumento de $9 \%$ em apenas três anos. Nesse mesmo período, a queda no número de exemplares foi de $15 \%$. Ora, se o número de exemplares caiu e o de títulos aumentou, então é razoável supor que jornais locais e de menor porte estejam florescendo, em detrimento de jornais maiores de circulação nacional. Se essa for uma tendência persistente no tempo, então estaremos diante da confirmação das teses segundo as quais a ênfase no consumo de informações se move do maciço e global para o individualizado e o local.

Essa tendência favoreceria os temas de âmbito individual, como saúde e comportamento, explorados nas capas de revistas semanais; a capacidade da internet, do rádio e até de alguns canais de TV a cabo, de chegar até sua audiência com informações específicas, localizadas e atualizadas, sobre trânsito, meteorologia, notícias da cidade e da comunidade e assim por diante. Dentre os jornais, aqueles de circulação e projeção nacional, como os três que são o objeto desta pesquisa, estariam em desvantagem, frente a jornais locais ou de segmentos profissionais (associações e sindicatos). Veremos, no entanto, que a situação é um pouco mais complexa do que sugere essas suposições do senso comum. 
Philip Meyer chama essa tendência de "desmassificação dos meios". Segundo ele, ela já havia sido documentada pelo sociólogo Richard Maisel uma geração atrás, quando não havia internet e computadores pessoais ainda eram caros e raros: "Ele viu que os meios de comunicação de massa estavam contraindo em relação ao resto da economia, e que a mídia especializada estava se expandindo, para ocupar o espaço." (MEYER, 2004, p. 2)

A tendência perpassa inúmeros meios: o número de espetáculos encenados em teatros menores estava aumentando, enquanto as apresentações "menos especializadas" da Broadway estavam declinando, observa o autor, com um exemplo tipicamente nova-iorquino. Os novos cinemas tinham menos poltronas (uma tendência agora observada no Brasil, com salas grandes dando lugar a várias salas menores). O mercado dos livros técnicos estava crescendo mais que os de ficção. Revistas bimensais e trimestrais estavam se saindo melhor que as mensais e semanais. E, finalmente, jornais locais estavam atraindo e mantendo leitores de forma mais efetiva do que jornais metropolitanos. A publicidade de nível nacional, predominantemente de caráter institucional, estava crescendo menos que os anúncios de varejo, voltados para mercados locais, enquanto que o classificado, "a forma mais especializada de publicidade", assinala Meyer, era o que mais crescia.

Mas há algo de intrigante nesse "localismo". Pesquisa da Knight Foundation feita em abril de 2002 em 32 jornais locais dos Estados Unidos mostrou que, quanto menor o jornal, menor a proporção de cobertura local. Em média, nos 32 jornais, o material produzido pela equipe local de repórteres foi de $46 \%$. Mas o espectro variou de $64 \%$, no Detroit Free Press, a $31 \%$, no The Macon Telegraph. O restante é coberto pelos grandes jornais que distribuem suas notícias, colunas e artigos para jornais menores, e pelas agências de notícias nacionais e internacionais. Philip Meyer, que cita a pesquisa em seu livro, comenta assim a sua conclusão:

Intuitivamente, se poderia pensar que jornais menores, sendo mais focados em suas comunidades, tivessem uma porcentagem maior de cobertura local, mas não é o caso. Talvez eles não possam custeá-lo. Um mercado razoavelmente maior poderia ser requerido para sustentar uma pesada cobertura local. (MEYER, 2004, p. 134) 
De fato, os números da pesquisa mostram que essa cobertura local cresce com o tamanho do mercado, definido como a tiragem do jornal no condado onde fica a sua sede, até atingir de 300 mil a 400 mil exemplares. A partir daí, a porcentagem de cobertura local se estabiliza. Meyer observa que os efeitos da economia de escala na capacidade de investimento na cobertura local são maiores nos primeiros degraus do aumento da tiragem, depois vão se desacelerando, até se anularem completamente a partir dos $400 \mathrm{mil}$ exemplares. Ou seja, quando atinge os 400 mil exemplares, o jornal tem rentabilidade suficiente para investir na cobertura local - que requer repórteres, fotógrafos, editores, carros, combustível e outros recursos dispendiosos. "Abaixo disso, a capacidade de um jornal de manter equipes para intensas coberturas locais é muito dependente do tamanho do mercado", escreve Meyer. Noutras palavras, em tese, um jornal com tiragem de 50 mil exemplares teria menos recursos para a cobertura local do que um com 200 mil exemplares.

O pesquisador sugere, no entanto, que o fato de jornais menores terem menos recursos para investir em reportagem não seja o único fator que explique 0 menor empenho na cobertura local. Pode ser também porque "jornais em comunidades menores não precisam fazer tanto esforço para manter uma boa penetração doméstica", escreve Meyer. "A dinâmica, e às vezes o isolamento de uma comunidade menor impulsionam a demanda por um jornal." Talvez jornais de comunidades menores se dêem bem com menos cobertura local porque não precisam tanto dela para terem êxito, propõe. (MEYER, 2004, p. 135) Ou seja, o papel dos jornais locais em comunidades seria o de arrancá-las da sensação de isolamento. E, para isso, seriam mais relevantes notícias de âmbito nacional e internacional do que notícias locais.

Essa é, naturalmente, a descrição de uma realidade específica dos Estados Unidos. No Brasil, é visível a ênfase dos jornais locais em temas locais - pela simples e boa razão de que os jornais de arculação estadual, regional ou nacional não dedicarão espaço à cobertura de temas cotidianos de cada comunidade. No entanto, aplica-se ao Brasil o raciocínio sobre a economia de escala. Coberturas locais são dispendiosas, porque exigem a mobilização de jornalistas, carros, motoristas, ligações telefônicas - enfim, todos os recursos 
que pressupõem a realização da reportagem. Enquanto isso, jornais menores dispõem de notícias estaduais, nacionais e internacionais provenientes de agências de notícias, que Ihes vendem pacotes fechados, por um preço relativamente baixo, graças ao grande número de clientes comprando exatamente o mesmo produto.

O economista James Hamilton mediu a correlação entre os temas explorados por jornais locais e os hábitos de consumo de outras fontes de informação com áreas temáticas definidas e detectou uma notável adesão dos editores desses jornais aos interesses dos leitores de suas respectivas comunidades. $O$ levantamento foi feito em 1999, com 68 jornais locais diários nas 50 maiores cidades dos Estados Unidos. Hamilton constatou que, quanto maior a porcentagem de assinantes da revista Time numa comunidade, maior a veiculação, nos jornais locais, de temas de hard news - que caracterizam essa publicação - em debate na época, como pobreza, sistema de saúde público, doações de campanha pelo caixa 2 e reforma da lei de financiamento de campanha. Quanto maior a circulação da revista People, dedicada a fofocas sobre celebridades, menos matérias sobre o sistema de saúde nos jornais locais. Quanto maior a circulação de Modern Maturity, dirigida aos idosos, menor a cobertura, nos jornais locais, sobre pobreza, computadores e aids. Áreas com mais assinantes de Playboy tinham menos matérias, nos jornais locais, sobre a distribuição de comida para os pobres (food stamps) e o sistema de saúde. (HAMILTON, 2006, p. 151)

A cobertura local ocupa os jornais locais, observa Hamilton, desde que ela seja de real interesse para seus leitores: "A incidência de um problema do mundo real numa cidade influencia na cobertura, desde que o problema seja de interesse dos prováveis leitores de um jornal." Assim, por exemplo, a política de food stamps, que esteve no noticiário dos grandes jornais naquele ano, teve menor cobertura em alguns jornais locais, diz Hamilton, porque é improvável que leitores de jornais sejam beneficiários da assistência social. Na verdade, ele observou uma correlação negativa: quanto mais pobre a comunidade e maior o número de destinatários de food stamps, menor a cobertura desses temas. Em contrapartida, quanto maior o número de programadores de 
computador numa cidade, maior o número de reportagens sobre o tema nos jornais locais.

Não nos aprofundaremos mais no tema dos jornais locais, que não são o objeto desta pesquisa. Apenas nos interessa, aqui, uma comparação entre o grau de informação de que dispõem os editores de jornais de circulação nacional e os de jornais locais, sobre os interesses de seus leitores, e a repercussão disso sobre o êxito de ambos os tipos de jornais. Editores de jornais locais tomam decisões com base num complexo sistema de interpretação dos interesses de suas comunidades, dos quais podem ter informações mais acuradas do que os editores de jornais nacionais, que se dirigem a uma platéia difusa, com múltiplos interesses. É igualmente improvável que os leitores dos jornais nacionais sejam usuários de food stamps (os equivalentes brasileiros seriam o Bolsa Família do governo federal ou os restaurantes populares de alguns governos estaduais) e de outros benefícios destinados aos pobres. Entretanto, os grandes jornais investem nesses temas pressupondo um interesse intelectual, de compreender o que se passa no país.

Assim, voltando à classificação de Anthony Downs, citada no capítulo anterior, segundo a qual a informação auxilia na tomada de decisões sobre consumo, produção, entretenimento e voto, o leitor pode ter a consciência de que o seu voto não alterará o resultado de uma eleição, sendo, portanto, desfavorável a relação custo-benefício de buscar a informação, para um resultado nulo. Segundo Downs, em função disso, para o eleitor é mais proveitoso manter-se "racionalmente ignorante". Acontece que há outras motivações para se informar sobre temas políticos, observa Hamilton: os deveres de cidadão, numa democracia; o fato de que para muitas pessoas, a política tem um interesse inerente; e a trama que enreda os atores políticos, como personagens de uma novela. (HAMILTON, 2006, p. 12) Todos esses aspectos podem compor o que se poderia chamar vagamente de motivações intelectuais, não diretamente vinculadas a um interesse prático e específico do leitor.

Um dos aspectos que distinguem o padrão de tomadas de decisão editorial de um jornal local e de um jornal de circulação nacional é esse: os editores do jornal local se guiam mais, em tese, para os interesses práticos e específicos de seus leitores; os do jornal nacional, ao lidar com um contingente maior e 
mais difuso de leitores, e ao mesmo tempo contando com mais espaço e mais recursos de reportagem, investem maciçamente em temas mais universais, que atendem a motivações intelectuais.

Mas os leitores parecem inclinar-se mais para os assuntos de interesse individual e local do que para os de interesse coletivo e nacional ou internacional. Isso pode explicar, em parte, o declínio na leitura dos jornais nacionais, nos últimos anos, e a sensação dos leitores de que ler um grande jornal é mais um ato de "obrigação" do que de "prazer". A pergunta é: até quando os leitores se sentirão obrigados a ler os grandes jornais? A motivação do leitor é um tema-chave.

\section{Motivações dos anunciantes}

Vimos, no capítulo 4, que o faturamento dos jornais tem aumentado, mas a um ritmo mais lento do que os de outros meios: a TV por assinatura, a internet, a TV aberta e o rádio. Apenas o faturamento bruto das revistas cresceu menos que o dos jornais, entre 2003 e 2004. O grosso do faturamento - no caso dos jornais, em torno de $75 \%$ - advém da venda de espaço, seja para anúncios publicitários (50\%), seja para anúncios classificados (os outros $25 \%$ da receita total). Num ambiente de surgimento de novos meios, é natural que haja uma reacomodação das verbas publicitárias. Vamos tentar esmiuçar, aqui, com apoio da literatura, as motivações dos anunciantes e dos profissionais de mídia.

Alfonso Sánchez-Tabernero (2000, p. 231) observa que, durante muitas décadas, as revistas consistiram no setor mais dinâmico da indústria da comunicação, com suas "possibilidades expressivas" superando amplamente as dos jornais (que só recentemente passaram a investir maciçamente em cor, qualidade de impressão e até de papel, para atrair anúncios publicitários antes restritos às revistas). Nos anos 50 , no entanto, a televisão emergiu como 0 meio de maior alcance e penetração, drenando as receitas publicitárias dos outros meios. Naquela década, algumas revistas que mantinham grandes tiragens, mas haviam sofrido queda brutal nos anúncios, tiveram de ser fechadas. Em 1956, desapareceram três grandes títulos nos EUA: American, 
Collier's e Woman's Home Companion. Nos anos 70, outros três títulos ainda mais famosos deixaram de circular: Saturday Evening Post, Look e a legendária Life.

A partir dos anos 80, para driblar a concorrência da televisão, lembra SánchezTabernero, muitos publishers do ramo de revistas passaram a lançar títulos especializados, dirigidos a leitores com perfis sócio-econômicos mais homogêneos. Já que não podiam fazer frente à audiência maciça dos grandes canais de TV, procuraram atender aos anunciantes que buscavam públicos específicos. O autor observa que os anúncios publicitários de publicações especializadas freqüentemente são de interesse direto para os próprios leitores - maximizando seus efeitos. Canais de televisão temáticos entraram nesse mercado. Mas as revistas especializadas continuaram mantendo algumas vantagens comparativas frente a todos os outros meios, enumera SánchezTabernero: especialização; boa reprodução em cores; informações detalhadas sobre seus assinantes; longos períodos de vigência (presença física nos domicílios, salões de beleza, cafés, salas de espera, e visibilidade nas bancas); elevado tempo de leitura por cada exemplar.

No Brasil, as editoras Abril, Globo e Três, entre outras, têm explorado intensamente esse filão das revistas especializadas, com um número crescente de títulos. Como vimos no capítulo 4, essas revistas são as reponsáveis pelo crescimento do número de títulos, apesar da queda do número total de exemplares.

O rádio tem experimentado um processo de especialização semelhante ao da revista, observa Sánchez-Tabernero, com o surgimento de emissoras especializadas em notícias ou em determinado tipo de música. Segundo o autor, o consumo de rádio também tem aumentado, apesar da aparição de outros meios: nos países mais ricos, diz ele, $60 \%$ dos adultos ouvem rádio diariamente e $90 \%$, semanalmente. As rádios têm custos mais baixos que jornais e revistas (que têm de arcar com papel, tinta e distribuição) e que televisões (que têm de pagar por filmes e direitos de transmissão de eventos esportivos, por exemplo). Com isso, podem cobrar mais barato pelos comerciais. São, também, meios mais flexíveis, que podem ser ouvidos no 
escritório, no carro, em casa, na praia, em lojas, consultórios, clubes e noutros locais públicos.

Apesar dessas vantagens, observa Sánchez-Tabernero, o rádio não obtém receitas publicitárias proporcionais à sua audiência. "As agências e anunciantes argumentam que é difícil medir a eficácia dos investimentos em rádio e que o fato de seu consumo constituir quase sempre uma atividade secundária - os ouvintes estão prioritariamente dirigindo, trabalhando, preparando a comida ou brincando com as crianças - limita o impacto das mensagens comerciais", escreve o autor (SÁNCHEZ-TABERNERO, 2000, p. 231-3). Sem contar que, em sua maioria, as emissoras têm cobertura local, o que limita o alcance dos anúncios.

A televisão é, desde meados do século 20, "o meio publicitário por excelência", anota Sánchez-Tabernero. Os comerciais veiculados na TV atingem todo o mercado. Além disso, o meio oferece "excelentes possibilidades expressivas, particularmente eficazes no âmbito mais emocional das decisões humanas". Os telespectadores se encontram numa atitude relaxada e receptiva.

A principal debilidade da televisão, diz o autor, são os custos elevados de produção e de veiculação, que comprometem, sobretudo, a relação custobenefício de anúncios locais. Seu período de vigência é muito curto. E o zapping - praticado por $20 \%$ a $40 \%$ dos telespectadores, que trocam de canal durante o intervalo comercial - reduz a eficácia dos anúncios.

$\mathrm{Na}$ internet, as vantagens, para o anunciante, são as seguintes, enumera Sánchez-Tabenero: a interatividade; o elevado nível sócio-econômico da audiência; o atrativo representado pela inovação tecnológica, e o baixo custo dos banners e de outras mensagens publicitárias. As desvantagens: a limitada penetração; a facilidade de se esquivar das mensagens; "a escassa experiência tanto na idealização de mensagens persuasivas não-lineares quando na tarefa de planejamento de mídia pelas agências".

Finalmente, o jornal se destaca pelo alto poder aquisitivo de seus leitores. Anúncios publicados nos jornais emprestam o prestígio dos jornais para as marcas dos anunciantes. Distribuídos fisicamente, os jornais permitem ao anunciante estabelecer uma clara estratégia geográfica. E os jornais contam 
ainda com o cadastro detalhado de seus assinantes, que permite ao anunciante um maior controle sobre o público-alvo.

$\mathrm{Na}$ mesma linha, o presidente da Associação Brasileira de Agências de Publicidade (Abap), Dalton Pastore, realça a delimitação geográfica dos jornais como o seu mais importante atributo na veiculação de publicidade:

Os jornais têm uma particularidade, uma característica relevante para a publicidade que quase nenhum outro veículo possui: o regionalismo. Ele pode publicar seus cadernos de notícias do Brasil e do mundo, mas o resto é voltado para os interesses de quem mora na região em que ele circula. Isso é muito bom tanto para o anunciante local, que tem o seu produto divulgado para 0 público a quem é familiar, quanto para o anunciante nacional, que consegue alcançar as regiões mais distantes de suas sedes, mas que têm acesso aos seus produtos ainda assim. (PAULINO, 2006a) ${ }^{35}$

De acordo com Pastore, "as revistas nacionalizam, os jornais regionalizam". Segundo ele, "os únicos veículos que podem concorrer $\infty m$ os jornais nesse sentido são o rádio e o outdoor, mas os jornais ainda ganham".

Como vimos no capítulo anterior, os leitores consideram o jornal o meio "mais completo". Os publicitários também, a julgar pelo que diz o vice-presidente de mídia da agência Fischer América, Cláudio Venâncio:

É um meio importante por ser útil para vários segmentos. Serve tanto à Brastemp, no caderno Paladar do Estado de São Paulo, quanto à concessionária de carros nos cadernos de veículos. (PAULINO, 2006b)

Em contrapartida, assinala Sánchez-Tabernero, o jornal não oferece os mesmos recursos expressivos da TV, do rádio e da internet. Uma edição de jornal dura apenas o transcurso de um dia, ao contrário das revistas, que perduram pelo menos uma semana. Um defeito reconhecido também por Cláudio Venâncio: "Em um dia, a publicação morre, e novas campanhas precisam ser publicadas logo, para não perder o trabalho inicial." Embora acredite que seja "compensado pela credibilidade do título em que escolhemos anunciar, pelo interesse que o leitor realmente tem naquele jornal".

Por último, acrescenta Sánchez-Tabernero, a qualidade gráfica de um anúncio de jornal sempre deixa a desejar, quando comparada à da revista. Os atributos de cada meio são listados na tabela 5 .

\footnotetext{
${ }^{35}$ Entrevista concedida a Raquel Paulino, da revista Imprensa, publicada em setembro de 2006.
} 


\section{TABELA 6}

Vantagens e desvantagens de cada meio de comunicação, segundo Sánchez-Tabernero

\begin{tabular}{|c|c|c|}
\hline Meio & Vantagens & Desvantagens \\
\hline Jornal & $\begin{array}{l}\text { Alto poder aquisitivo dos leitores } \\
\text { Prestígio para a marca } \\
\text { Segmentação geográfica } \\
\text { Muita Informação sobre assinantes }\end{array}$ & $\begin{array}{l}\text { Possibilidades expressivas } \\
\text { limitadas } \\
\text { Qualidade de reprodução limitada } \\
\text { Ciclo de vida breve }\end{array}$ \\
\hline Revista & $\begin{array}{l}\text { Ciclo de vida prolongado } \\
\text { Boa qualidade de reprodução } \\
\text { Muita informação sobre assinantes } \\
\text { Segmentação por conteúdos }\end{array}$ & $\begin{array}{l}\text { Dificuldade de atingir alta } \\
\text { cobertura do mercado } \\
\text { Inflexibilidade para mudar } \\
\text { anúncios } \\
\text { Preços relativos elevados } \\
\end{array}$ \\
\hline Rádio & $\begin{array}{l}\text { Capacidade de selecionar a } \\
\text { audiência } \\
\text { Flexibilidade no uso: imediatez e } \\
\text { mobilidade } \\
\text { Produção rápida e barata } \\
\text { Facilita a repetição da mensagem } \\
\end{array}$ & $\begin{array}{l}\text { Atenção escassa } \\
\text { Não permite uso de imagens } \\
\text { Sintonia por períodos curtos } \\
\text { Fragmentação da audiência }\end{array}$ \\
\hline Televisão & $\begin{array}{l}\text { Audiência maciça } \\
\text { Excelentes recursos expressivos e } \\
\text { persuasivos } \\
\text { Atitude receptiva dos espectadores }\end{array}$ & $\begin{array}{l}\text { Custos elevados de produção e } \\
\text { veiculação } \\
\text { Público pouco selecionado } \\
\text { Zapping } \\
\text { Blocos de comerciais longos }\end{array}$ \\
\hline Meio & Vantagens & Desvantagens \\
\hline Internet & $\begin{array}{l}\text { Interatividade } \\
\text { Atrativo tecnológico } \\
\text { Baixo custo } \\
\text { Alto poder aquisitivo dos usuários }\end{array}$ & $\begin{array}{l}\text { Alcance limitado } \\
\text { Pouca experiência acerca de sua } \\
\text { eficácia, produção e planejamento }\end{array}$ \\
\hline
\end{tabular}

Fonte: SÁNCHEZ-TABERNERO, 2000, p. 234.

Para medir os efeitos do deslocamento de anúncios publicitários de um meio para outro, não basta comparar a evolução das respectivas receitas. Seria preciso analisar cada meio. Isso porque cada um tem uma composição de fontes de receita. As TVs abertas e as emissoras de rádio faturam quase que exclusivamente com os comerciais. As TVs por assinatura, com um mix de comerciais e do pagamento das assinaturas. A internet, com a venda de seus acessos para provedores, que por sua vez cobram dos assinantes de seus serviços; com a venda de espaços publicitários e com a venda de links, como 
os que conduzem o leitor para sites de compras, por exemplo. Revistas e jornais faturam com as vendas em banca, de assinaturas e de espaços publicitários.

Alfonso Sánchez-Tabernero observa que, nas emissoras de rádio e de TV abertas comerciais - ou seja, nem públicas nem por assinatura -, a receita publicitária tende a representar mais de $90 \%$ do faturamento total. Nas revistas econômicas e financeiras, ela chega a superar $50 \%$, diminuindo nos guias de TV e nas publicações literárias e culturais. Nos jornais, os anúncios publicitários geram entre $40 \%$ e $80 \%$ da receita total. "A proporção de receitas publicitárias tende a ser maior em países mais prósperos, em jornais com grandes fatias de mercado e leitores de alto poder executivo, e decresce em mercados menos desenvolvidos, na imprensa popular e nos jornais esportivos", diz o autor. (SÁNCHEZ-TABERNERO, 2000, p. 221)

Num grande jornal brasileiro, tipicamente, a receita de circulação - assinaturas mais venda avulsa - representa cerca de $25 \%$ do total; a de publicidade, os restantes $75 \%$. Desses, dois terços ou $50 \%$ do total da receita) advêm de anúncios publicitários; e o outro terço ( $25 \%$ do total da receita), de classificados.

De acordo com Pastore, nas últimas duas décadas, a situação dos jornais no mercado publicitário é "entre estável e perdendo um pouquinho". Para o publicitário, essa perda dos jornais "é um processo lento, longo". Pastore assegura que "o jornal é muito presente na vida dos brasileiros, e não vai desinteressar ao mercado publicitário de uma hora para outra". Ele enumera as causas dessa perda de interesse, ainda que lenta e gradual:

O surgimento de novos ambientes para anúncio, como a internet, a TV a cabo. Eles não existiam dez anos atrás, e hoje existem de forma ampla entre a classe média, que é o principal público-alvo do mercado publicitário. (PAULINO, 2006a)

Na opinião de Pastore, a internet ainda não representa uma ameaça para os jornais diários por dois motivos: embora tenha um grande contingente de usuários, ela ainda "não está tão presente assim na vida dos brasileiros", e "a penetração do jornal é mais sólida"; e "não se descobriu ainda como anunciar na internet". Segundo o publicitário, "estamos na idade da pedra-lascada em termos de anúncios nesse ambiente web". Pastore admite, no entanto, que se 
vai descobrir como dominar esse ambiente. Ele não sabe estimar quanto tempo levará até que a internet se torne "significativa" para o mercado publicitário, nem se ao fim ela vai subtrair mercado dos jornais. (PAULINO, 2006a)

Os recursos de hipertexto permitem que conteúdos informativos da internet se entrelacem com campanhas publicitárias e mercadológicas. Um tema ou 0 nome de uma pessoa pode remeter a um livro à venda, por exemplo. Essas possibilidades têm sido exploradas pelos meios digitais, ainda que de forma incipiente. Essas práticas tendem a romper o tabu da separação entre a redação e o departamento comercial, considerado, pelos jornalistas, a chave da independência e da credibilidade de seu trabalho. Do outro lado do "muro", Pastore advoga a sua preservação:

[...] todo profissional de comunicação que se preze tem uma relação sagrada de separação entre o editorial e o comercial, e isso vale dos dois lados, tanto para os jornalistas quanto para os publicitários. Quanto mais rigorosa for essa separação, melhor. Não é interessante para ninguém que haja invasão dos anúncios nas matérias. Para o jornal, resulta na perda da credibilidade. Para o anunciante, na antipatia que o público cria por ele, por considerá-lo desrespeitoso. (PAULINO, 2006a) ${ }^{36}$

Do cenário descrito acima, não emerge um problema estrutural para a publicidade nos jornais. As características do meio jornal ainda the asseguram uma fatia no mercado, enquanto houver anunciantes que valorizem o alto poder aquisitivo de seus leitores, o prestígio de sua marca, a segmentação geográfica de seu produto e o perfil conhecido de seus assinantes. É por isso que o faturamento dos jornais segue aumentando, ainda que em ritmo menor que o de outros meios.

\section{Custo-benefício}

A rentabilidade de um jornal é resultado de fatores que interagem de forma complexa. Não há uma relação direta entre circulação e rentabilidade. Um jornal não se torna mais rentável quando aumenta sua circulação. O contrário pode acontecer. Por isso, ao contrário do que o senso comum faria supor, o

\footnotetext{
${ }^{36}$ Pastore respondia a uma pergunta específica sobre os anúncios de formatos nãoconvencionais, que "invadem" o espaço reservado às matérias, nos jornais. Mas, em linhas gerais, seu raciocínio pode se aplicar também às possíveis "intromissões" do comercial no editorial, nas versões online dos jornais.
} 
tamanho da circulação de um jornal não é conseqüência direta do número potencial de leitores que esse jornal tem no mercado.

Isso porque entregar um jornal na casa de um leitor ou na banca mais próxima dele pode custar mais caro do que o eventual aumento de receita resultante dessa entrega. Pesquisa feita para a Associação Nacional de Jornais indica que o custo médio, em 19 jornais do País, de atendimento ao leitor e de entrega do jornal foi de $\mathrm{R} \$ 0,80$ por exemplar em 2005. (OLIVEIRA, 2006) É cerca de metade a um terço do preço de venda avulsa dos jornais na banca, dependendo do título.

Quanto mais longe o leitor morar, e quanto menos leitores houver na área onde ele mora, mais caro ainda é levar o jornal até ele. Simplificando: levar um caminhão cheio de jornais para uma determinada região do interior de São Paulo pode valer a pena. Mas, se houver mais leitores potenciais na mesma região, que não encham um segundo caminhão, pode não valer a pena atendêlos. Os jornais consumidos em locais mais distantes têm um preço de venda avulsa e de assinatura mais alto do que na cidade-sede do jornal. Mas essa diferença não cobre o aumento de custo do transporte. Até porque, conforme assinalamos acima, o preço de venda do jornal - somando avulsa e assinatura - representa apenas cerca de $25 \%$ da receita de um jornal. Portanto, $75 \%$ dos custos fixos e variáveis são cobertos pela receita de publicidade. Se o custo de levar o jornal para um ponto mais distante não trouxer um retorno publicitário condizente com o que a empresa considerar compensador, então a tendência será de não atender à demanda do mercado naquele lugar. Tipicamente, num grande jornal brasileiro, a receita publicitária está dividida assim: dois terços provenientes da venda de anúncios e um terço, da venda de classificados, que são um produto predominantemente local. Além disso, no conjunto dos anúncios publicitários, os anúncios de varejo, dirigidos para o público local, têm um peso significativo. ${ }^{37}$ Tudo somado, a circulação do jornal fora do entorno de sua sede tende a ser pouco rentável e, freqüentemente, a gerar prejuízo.

\footnotetext{
${ }^{37}$ Nos Estados Unidos, a participação dos anúncios de varejo no bolo das receitas de publicidade dos jornais é de $44 \%$; dos anúncios nacionais, $16 \%$; e dos classificados, $40 \%$. 0 dado é de PICARD, Robert G. Evolution of revenue streams and the business model of newspapers: the U.S. industry between 1950-2000, in Newspaper Research Journal, edição de outono de 2002, apud MEYER, 2004, p. 37.
} 
A Tribune Company, proprietária do jornal Los Angeles Times, anunciou, em dezembro de 2005, o fim de sua edição de circulação racional. A empresa constatou que a maioria dos leitores do jornal na Costa Leste o acessava pela internet, e decidiu investir na melhoria de sua versão online. O jornal continuou disponível em papel por meio de um sistema de envio eletrônico para distribuidoras que o imprimem e entregam em locais como hotéis. O sistema, chamado de NewspaperDirect, é usado por dezenas de jornais em dezenas de países. (SEELYE, 2005)

No que se refere à circulação, os três grandes jornais brasileiros que são objeto deste estudo tomaram rumos distintos nos últimos anos. A Folha tomou a decisão estratégica de custear a distribuição no Brasil e no interior de São Paulo, apesar de isso gerar prejuízo. De olho na planilha de custos, o Estado se decidiu pelo inverso, priorizando a circulação na cidade de São Paulo e reduzindo sua circulação no interior do Estado e, sobretudo, no restante do País, a um mínimo percebido como o necessário para manter a sua característica de jornal de projeção nacional. No fim de 2005, estava revendo essa decisão, informou Sandro Vaia. O então diretor de redação do Estado definiu assim a mudança de paradigma na avaliação da relação custo-benefício da abrangência de circulação:

Aí, não se passa mais a considerar como custo por mil, para anunciante, etc. Mas como um jornal influente e importante. É evidente que é importante anunciar num jornal importante. Para o anunciante, isso quer dizer muita coisa. Se o jornal deixa de circular em centros de influência - São Paulo, Rio de Janeiro, capitais - e junto a públicos formadores de opinião - universitários, tomadores de decisão, empresários -, ele perde influência. Perdendo influência, evidentemente, perde circulação, e perdendo sua circulação, perde sua eficácia como veículo de publicidade. ${ }^{38}$

A circulação de um grande jornal do Rio tem características diferentes. Conforme explicou Rodolfo Fernandes, os jornais do Rio entregam para algumas poucas dezenas de representantes, que são donos de conjuntos de bancas, e se encarregam da entrega na cidade. Além disso, o interior do Rio é muito menor, em área e em número de cidades, do que o interior de São Paulo. Esses dois fatores reduzem os custos de distribuição. A par dessas vantagens, - Globo tem buscado um meio termo entre o investimento pesado numa circulação nacional onerosa e o encolhimento para o perímetro da cidade-sede,

\footnotetext{
${ }^{38}$ Em entrevista ao autor, cuja íntegra está em Anexos.
} 
por preocupações exclusivamente contábeis. Rodolfo Fernandes definiu assim a estratégia do jornal:

O Globo tem como sua definição estratégica ser um jornal da classe média do Rio de Janeiro, com prestígio e repercussão nacional. Isso foi deliberado alguns anos atrás. E não faz loucura para isso. Não vejo o Globo apontando na direção dessa operação que a Folha tem, por exemplo. ${ }^{39}$

No frigir dos ovos, os custos com distribuição, somados aos de impressão, na Folha, representam cerca de $40 \%$ do total; no Estado, cerca de 35\%; no Globo, um pouco menos que isso.

Alfonso Sánchez-Tabernero observa que, para os jornais, revela-se "chave alcançar uma posição de liderança em seus respectivos mercados". Afinal, pondera ele, "o líder de vendas tem muitas possibilidades de se converter também no líder do mercado publicitário". (SÁNCHEZ-TABERNERO, 2000, p. 228) Claro que com a condição de que ele esteja competindo com um jornal de qualidade compatível, dirigido, portanto, ao mesmo público-alvo.

A revista Advertising Age conta que Rupert Murdoch, dono do tablóide sensacionalista The New York Post, tentava convencer o executivo de uma cadeia de lojas de alto nível a não anunciar apenas no prestigioso The New York Times, mas também no seu jornal popular, já que o primeiro superava o segundo em circulação. A resposta do executivo, narra a revista, foi a seguinte: "Mr. Murdoch, os leitores do Times são os que compram em nossas lojas; os do Post são os que as limpam..." 40

Sánchez-Tabernero estima que, em um mercado local ou regional em que concorram dois jornais com leitores de perfil econômico similar e cujas fatias de mercado sejam de $65 \%$ e $35 \%$, respectivamente, a distribuição das receitas de publicidade locais e regionais podem ser de $70 \%$ frente a $30 \%$, e a das receitas nacionais, de $85 \%$ a $15 \%$. "O prêmio de cota publicitária para os jornais líderes em vendas se refere a que muito poucos anuncantes incluem suas mensagens comerciais só no segundo ou no terceiro título, ainda que eles ofereçam preços proporcionalmente mais baixos que o jornal de maior difusão", analisa o autor. Sem contar que muitas agências e anunciantes nacionais, ao planejar suas campanhas, concentram-se nos líderes.

\footnotetext{
${ }^{39}$ Id.

${ }^{40}$ Citada por SÁNCHEZ-TABERNERO, op. cit., pp. 228-9
} 
Daí que os principais jornais de circulação em toda a Europa - The Wall Street Journal Europe, Financial Times e International Herald Tribune - precisam consolidar uma presença importante em seus respectivos mercados nacionais, observa Sánchez-Tabernero. Em contrapartida, outros títulos, como o semanário The European, com um volume de circulação razoável, não têm sido capazes de gerar receitas publicitárias suficientes, em razão de não conseguirem ocupar uma fatia significativa do mercado. (SÁNCHEZTABERNERO, 2000, p. 229)

A posição de liderança e a projeção nacional de um grande jornal têm custos. Mas têm também benefícios. Sua distribuição e circulação seriam menores, se se considerasse apenas a relação custo-benefício contábil. Mas o jornal não é um negócio como outros. Se o valor institucional de uma marca é importante em qualquer produto, no jornal, ele é crítico. Prestígio e influência são ativos, que resultam, ainda que indiretamente, em rentabilidade. A seguir, discutiremos com mais detalhe esse universo de valores intangíveis, que vai muito além da estratégia de circulação e distribuição, e se estende por todas as decisões de um jornal.

\section{Gestão de valores intangíveis}

O cálculo puramente contábil não é o único a nortear as decisões comerciais de um grande jornal. Nessas decisões, têm de ser levados em conta, também, valores intangíveis ${ }^{41}$, como o prestígio, a repercussão, a projeção nacional. Chamaremos esse conjunto de valores intangíveis - que incluem também "caprichos do dono", como cadernos, seções, colunas que não são rentáveis do ponto de vista publicitário, grandes reportagens, correspondentes no exterior - de "influência"42.

A circulação e a amplitude da distribuição dos grandes jornais refletem o equilíbrio entre o balanço contábil, de um lado, e a busca da influência, de outro. $O$ mesmo se aplica ao equilíbrio entre o investimento em qualidade e a rentabilidade no curto prazo. "A aposta na qualidade implica uma certa

\footnotetext{
${ }^{41}$ Para uma discussão sobre os valores intangíveis na economia da informação, ver STIGLITZ, 2001.

42 O termo é adotado por MEYER, 2004.
} 
renúncia em obter a máxima rentabilidade no curto prazo", assinala Alfonso Sánchez-Tabernero. (2000, p. 107).

O autor exemplifica: uma forma simples e rápida de aumentar a rentabilidade de um veículo como a revista National Geographic seria reduzir de modo significativo o número de fotos que ela publica em cada edição. Com essa medida, a revista economizaria a cada ano milhões de dólares, sem que ocorresse uma queda de receita de curto prazo. Da mesma maneira, diz Sánchez-Tabernero, a CNN ou El País poderiam diminuir o número de correspondentes; a revista Hola poderia usar um papel de menor qualidade; 0 Frankfurter Allgemeine Zeitung ou o Yomiuri Shimbun poderiam reduzir o tamanho de suas redações. "Entretanto, é precisamente o investimento em qualidade, a renúncia a maximizar os benefícios de curto prazo, o que faz esses meios fortes, o que lhes proporciona prestígio e constitui sua principal barreira de entrada de possíveis concorrentes", argumenta o autor.

Mas, se poderia perguntar: o que é qualidade? Ao redor do mundo, pesquisadores têm tentado traduzir esse conceito abstrato em valores tangíveis. Um exemplo próximo é o valor agregado jornalístico (VAP, na sigla em espanhol), um índice criado pela pesquisadora chilena Silvia Pellegrini para avaliar a qualidade dos jornais. O índice é resultado de uma fórmula matemática que inclui 54 atributos de cada reportagem e da publicação como um todo - incluindo a quantidade e a qualidade das fontes ouvidas, o tamanho de cada texto e o ponto de vista usado para narrar os fatos. (WESTIN, 2006 e ALCÂNTARA, 2006)

Grandes jornais sul-americanos, como o Clarín e a La Nación, na Argentina, e El Comercio, no Peru, têm-se submetido a esse critério de avaliação de qualidade. "A mídia, que é muito competitiva, tem-se dado conta de que precisa de meios objetivos de avaliar seu trabalho", constata Pellegrini.

Coberturas importantes, que dão prestígio a um jornal e uma imagem de qualidade e influência, podem ser extremamente dispendiosas. Exemplo atual de alto investimento numa cobertura é o do conflito no Iraque, dada sua longa duração e os riscos para a segurança dos jornalistas. Em outubro de 2006, a publicação especializada francesa Leblogmedias noticiou que o jornal The New 
York Times gasta anualmente US\$ 3 milhões com sua cobertura no Iraque. $O$ custo inclui o pagamento de até 45 guardas de segurança armados, que patrulham as duas casas ocupadas pelos prnalistas e os escoltam em suas saídas em três veículos blindados. O jornal mantém de quatro a cinco repórteres de texto e dois repórteres fotográficos de seus quadros no Iraque, além de comprar matérias de mais de 70 free-lancers iraquianos, que têm maior facilidade de acesso a áreas sob influência de grupos hostis à ocupação americana. (LEBLOGMEDIAS, 2006)

É impossível estabelecer relação direta entre os custos de uma cobertura como essa e um eventual incremento de rentabilidade resultante do prestígio e da influência que ela confere ao jornal. Enquanto a cobertura está ocorrendo, ela não representa mais que isso para o jornal: custo. Esse é o dado concreto. $O$ resto é abstrato, uma aposta em algo que pode se converter em frutos - ou não. Por isso, decisões como a de fazer e manter uma cobertura como essa gera enormes tensões no interior dos jornais.

No Brasil, o equivalente à cobertura do Iraque seria a cobertura da Copa do Mundo. A cada quatro anos, os diversos departamentos dos grandes jornais se sentam para negociar a estratégia para a Copa. A premissa é a de que um bom projeto de cobertura atrairá a atenção do leitor e, com ela, anúncios publicitários. O departamento comercial corre atrás de anúncios, enquanto a redação escala dezenas de repórteres de texto e fotográficos e faz reservas de passagens e de hotéis a preços inflacionados pelo grande número de torcedores e de jornalistas em busca de acomodação. Invariavelmente, a cobertura custa mais do que o que ela atrai em receita publicitária extra. Entretanto, argumentam os jornalistas, uma cobertura da Copa de nível abaixo do esperado pelo leitor pode minar irremediavelmente a sua fidelidade ao jornal.

Entre os três diretores de redação dos jornais que são objeto deste estudo, há a percepção de que a planilha de contabilidade não pode ser o único parâmetro de decisão estratégica. Esse raciocínio se aplica não apenas à abrangência da circulação, mas, também, aos outros investimentos que o jornal faz, em cadernos que não se pagam pelos anúncios publicitários que atraem, em coberturas caras, na contratação de profissionais a peso de ouro e assim por 
diante. Rodolfo Fernandes, o diretor de redação de $O$ Globo, descreve assim essa relação:

O jornal é um conjunto de coisas. Não acredito que nenhum jornal brasileiro tenha um caderno literário rentável. Pelo contrário. Jornalismo é uma operação cara. Correspondente no exterior é uma operação cara. Ter um correspondente em Pequim é uma operação complicada. Manter uma sucursal em Brasília é uma operação caríssima. Ou a pessoa tem a compreensão de que jornalismo de qualidade é caro, mas dá retorno, se não todo mundo faria jornal popular, que é barato de fazer, mas não dá retorno. A margem de lucratividade que os jornais populares dão é muito pequena. ${ }^{43}$

Entretanto, esta é também uma geração de editores vacinada contra o "esbanjamento" do passado - gastos desenfreados que desequilibravam a contabilidade, sem necessariamente retornar em influência, prestígio e rentabilidade. Isso porque, em grande medida, tratava-se de gastos para satisfazer os anseios de prestígio não dos jornais, mas dos jornalistas.

Dos anos 70 até a primeira metade dos anos 90 , a inflação alta distorcia a relação entre receitas e custos. Na segunda metade dos anos 90 , o ganho no poder aquisitivo, decorrente da estabilização da moeda, e, no caso da imprensa, o barateamento relativo dos custos dos insumos importados (papel, tinta, equipamentos), pelo real forte frente ao dólar, permitiram aos jornais manter os gastos correntes e investimentos elevados. Então, veio a desvalorização do real, em janeiro de 1999, e um pesado desequilíbrio entre custos - incluindo os das dívidas em dólar - e receita. A crise obrigou os jornais a um rigoroso ajuste dos gastos correntes e investimentos. Fortemente endividadas, as empresas jornalísticas foram obrigadas a racionalizar seus custos e ganhar eficiência e rentabilidade.

Passada a crise, e mantida a estabilidade da moeda, o que se verifica é uma nova cultura nas empresas jornalísticas, que se poderia chamar de "responsabilidade fiscal", se quisermos tomar emprestado um termo da esfera pública.

A busca do ponto de equilíbrio entre finanças saneadas e qualidade é definida assim por Otavio Frias Filho, o diretor de redação da Folha de São Paulo:

Acho que é preciso separar o joio do trigo. Em toda a nossa cultura jornalística, da qual a gente proveio, na qual a gente ainda está imerso, sempre havia uma margem de desperdício. E sempre foi também uma cultura jornalística onde

\footnotetext{
${ }^{43}$ Entrevista ao autor, cuja íntegra encontra-se em Anexos.
} 
havia menos preocupação com as demandas reais do leitorado e uma enorme preocupação com a auto-imagem dos jornalistas, com tradições do próprio veículo, com uma visão mais conceitual do jornalismo. Acho que isso tudo está sendo corrigido e é bom que seja corrigido. O que eu acho que é o pulo do gato [...] é uma política que não implique em 8 nem 80 , ou seja, que a gente reduza as margens de desperdício, de esbanjamento, etc., que a gente focalize mais as demandas reais do leitor, e para isso é preciso conhecê-las mais, estudá-las mais, e trazê-las mais perto do cotidiano das redações. ${ }^{44}$

As entrevistas com os diretores de redação foram realizadas no momento em que os três jornais registravam marcas históricas de rentabilidade. Sandro Vaia citou números da empresa de consultoria em gestão McKinsey, segundo os quais a rentabilidade média dos jornais no mundo é de $25 \%$, e a dos jornais brasileiros, entre $10 \%$ e $20 \%$. De acordo com Otavio Frias Filho, no fim de 2005, a Folha estava operando com margens de lucro da ordem de $16 \%$ a 17\%. "São números muito bons e também inéditos para nós. Nunca tivemos margens tão altas", afirmou. "Estamos ainda dentro desse patamar", disse ele, referindo-se ao Estado. "Este mês é o de maior faturamento da história do Globo, e deve ter sido da Folha e do Estado também", observou Rodolfo Fernandes, em novembro de 2005. Para Otavio Frias Filho, esses resultados são conseqüência dos cortes de gastos, feitos no período de crise, desencadeada pela explosão das dívidas contraídas em dólares pelos três grupos, com a desvalorização do real, em 1999.

Num certo sentido, esses jornais parecem ter atingido um determinado ponto de equilíbrio entre investimento e receita. Os três diretores assinalaram que os atuais patamares de circulação e de publicidade garantem a saúde financeira de seus respectivos jornais - e, com ela, a independência editorial. Para Otávio Frias Filho, a experiência da bonança da segunda metade da década de 90 , seguida da perda violenta de receitas da primeira metade dos anos 2000 , pode ter tido um efeito salutar na dinâmica da gestão dos jornais, embora ele lamente que os investimentos se tenham estabilizado num patamar baixo:

Embora nós tenhamos cortado drasticamente despesas, num nível seguramente além do que acharíamos razoável, aprendemos a cortar, a administrar a escassez de recursos, a nos adaptar a essa situação, que tenho a impressão de que veio para ficar. Não acredito que nós vamos voltar àquele período - olhando com os olhos de hoje sou tentado até a dizer - de quase esbanjamento que tivemos nos anos 80 e 90 . Eu me lembro, por exemplo, de que na Copa do Mundo da França, em 1998, a Folha mandou 32 pessoas.

44 Id. 
Hoje, a gente olha, e fala: é realmente uma loucura. Aprendemos a trabalhar com recursos mais escassos. ${ }^{45}$

Como se vê, na atual geração de diretores de redação está entranhada uma cultura que leva em conta tanto os aspectos estritamente contábeis quanto os valores intangíveis que são ativos desses três grandes jornais. Há uma tentativa de superar o antigo conflito entre a contabilidade e os "caprichos de jornalistas". Os três grandes jornais ainda realizam coberturas dispendiosas, ainda publicam - e até criam novos - cadernos com pouco retorno publicitário, ainda mantêm correspondentes no exterior e colunistas caros. Ao mesmo tempo, registram rentabilidades históricas e sólida saúde financeira.

Em grande medida, esse quadro está vinculado ao modelo de gestão adotado nos últimos anos pelos grandes jornais. É o que mostraremos a seguir.

\section{Modalidades de gestão}

Há três modalidades de propriedade e de gestão de jornais. A primeira, e tradicional, são famílias de jornalistas, cujos avôs ou bisavôs em geral fundaram ou compraram os jornais, que seguem nas mãos de seus herdeiros, que continuam seus proprietários e gestores. É o caso da Folha de São Paulo. Os irmãos Otavio Frias Filho e Luís Frias herdeiros do jornal, gerem, respectivamente, a redação e as áreas comercial, financeira e industrial. A segunda é uma forma intermediária, na qual a propriedade continua com a família herdeira, que, no entanto, mantém-se apenas nos conselhos de administração, deixando o dia-a-dia da gestão para profissionais contratados. Foi o que fizeram as famílias Marinho, nas Organizações Globo, e Mesquita, no Grupo Estado. A terceira modalidade é a abertura de capital das empresas que editam os jornais. A propriedade, ou parte dela, sai das mãos dos herdeiros e vai para as de acionistas. Não há exemplo disso no Brasil. O caso que mais se aproxima é o do Grupo Abril, que anunciou, em maio de 2005, a venda de 30\% de seu capital ao grupo de mídia sul-africano Naspers, por US\$ 422 milhões. A

\footnotetext{
${ }^{45}$ Id. Na cobertura da Copa do Mundo de 2006, cada um dos três grandes jornais envi ou entre 20 e 25 profissionais. Além dos textos e fotos para os respectivos jornais, esses profissionais também alimentaram seus portais na internet, com informação em tempo real. Os custos ficaram entre $\mathrm{R} \$ 1$ milhão e $\mathrm{R} \$ 1,5$ milhão, para cada jornal, segundo dados obtidos pelo autor.
} 
família Civita, no entanto, fundadora do grupo, manteve-se no controle acionário, com $70 \%$ das ações, e do conteúdo editorial das revistas que edita.

O senso comum - pelo menos entre os jornalistas - é o de que empresas familiares, fundadas por jornalistas e dirigidas por seus descendentes, em geral também jornalistas, tendem a dar mais peso aos valores intangíveis do que empresas comandadas por executivos, pressionados a prestar contas sobre a rentabilidade do negócio, sobretudo no caso de companhias com ações nas bolsas de valores, que respondem diretamente a seus investidores. Os descendentes dos fundadores, segundo essa visão, conservariam o "espírito romântico" de seus antepassados, mais inclinados ao jornalismo que ao negócio em si. Já os executivos contratados, muitas vezes provenientes de outros ramos, tenderiam a transpor a cultura gerencial de outros negócios para o jornal, passando por cima de suas peculiaridades.

Nos Estados Unidos, a partir do fim dos anos 60, jornais dirigidos por empresas familiares abriram o seu capital e colocaram suas ações na Bolsa de Valores. A primeira operação dessa natureza ocorreu em 22 de abril de 1969, quando John S. Knight, o fundador do grupo de jornais Knight Ridder, um dos maiores dos Estados Unidos, ofereceu 950 mil ações na Bolsa de Valores. A relutância de Knight em perder o controle editorial sobre os jornais do grupo, no entanto, ficou clara na advertência que fez a analistas de Wall Street, que o convidaram a falar: "Senhoras e senhores, não pretendo tornar-me seu prisioneiro." Numa entrevista que concedeu alguns anos mais tarde, Knight recordou:

Eu disse a eles que, enquanto eu tivesse alguma coisa a ver com isso, nós íamos mandar nos nossos jornais. Às vezes, íamos gastar dinheiro sem que eles entendessem por quê, para ganhos futuros, e não pretendíamos ser regulados ou dirigidos por eles sob nenhum aspecto. ${ }^{46}$

Com o passar no tempo, no entanto, pôde-se perceber a mudança de atitude dessas empresas, no balanço entre contabilidade e influência. Como observa Philip Meyer:

Nos últimos anos, na medida em que a propriedade se deslocou de indivíduos e famílias para acionistas guiados por gerentes financeiros profissionais e analistas de mercado, um horizonte de tempo mais curto passou a dominar os negócios em geral nos EUA. A indústria do jornal não é exceção. (MEYER, 2004, p. 9)

\footnotetext{
${ }^{46}$ John Shively Knight 1894-1981, a tribute to an American editor, Akron Beacon Journal, offprint, junho de 1981, apud MEYER, 2004, p. 174.
} 
Esse "horizonte de tempo mais curto" se expressa num maior imediatismo em obter rentabilidade nas operações - ou descartá-las.

Meyer lembra que, quando as empresas proprietárias de jornais começaram a abrir seus capitais, nos anos 60, Wall Street não demonstrou interesse imediato. Era uma indústria já madura, e as novas tecnologias, como a televisão, já começavam a desviar verbas publicitárias dos jornais, da mesma maneira que novas publicações especializadas, que surgiram com 0 barateamento e a simplificação dos processos de impressão gráfica.

Segundo Meyer, foi Al Neuharth, da Gannett Company (grupo de mídia proprietário do USA Today), que mostrou aos investidores o potencial de rentabilidade de jornais que gozavam de monopólio em mercados pequenos e médios. "Esses monopólios não tinham, em sua maior parte, sido geridos para maximizar a lucratividade no curto prazo", analisa Meyer. "Seus proprietários, em parte por causa de um senso de responsabilidade social, em parte com um olho na saúde de suas companhias no longo prazo, estavam mais interestados em influência do que em maximizar suas fortunas." (MEYER, 2004, p. 11)

Leonard Downie Jr. e Robert G. Kaiser, dois experientes jornalistas que fizeram carreira no The Washington Post, lembram que, até os anos 60, a maioria dos jornais americanos era de proprietários locais, pertencentes às cidades onde eles eram publicados:

O jornal, seu diretor-responsável (publisher) e seu editor eram normalmente pilares da comunidade. Isso nem sempre era bom para o jornalismo. Muitos donos se preocupavam mais com seus amigos no Country Club - os outros pilares da comunidade - do que em servir seus leitores, e muitos desses donos abafavam coberturas agressivas dessas instituições. (DOWNIE JR. e KAISER, 2002, p. 68)

Os melhores proprietários, reconhecem os autores, elevavam-se acima de interesses paroquiais e encorajavam o jornalismo independente. Havia bons e maus jornais sob esse modelo. Hoje em dia, no entanto, as grandes cadeias corporações com ações nas bolsas de valores - possuem $80 \%$ dos jornais americanos. E a maioria "está focada em lucros, não em jornalismo", avaliam. "Diretores de redação que antes passavam seus dias trabalhando com repórteres e editores sobre as matérias, agora passam mais tempo em reuniões com executivos, tramando estatégias de marketing ou campanhas de redução de custos", observam os autores. 
Downie Jr. e Kaiser estão entre os muitos jornalistas que acreditam que os jornais pertencentes a empresas familiares, fundados por jornalistas e dirigidos por seus descendentes, tendem a fazer mais concessões aos gastos supostamente supérfluos em reportagens, colunas, cadernos e mesmo na distribuição em mercados que não são rentáveis, por acreditarem que é bom para a credibilidade, a qualidade, o interesse público ou a influência do jornal, do que aqueles administrados por gerentes financeiros que prestam contas a investidores.

Como quase tudo no jornalismo, não é uma posição unânime. Jack Fuller é um dos que questionam essa visão:

Por mais estranho que possa parecer para alguns de nós que ainda se lembram de como era trabalhar em jornais pertencentes a donos particulares, há jornalistas que sentem saudade daquele arranjo institucional. Parecem terse esquecido de algumas de suas piores qualidades: o sistema de gestão autoritário, no qual editores eram como crianças diante do pai poderoso; o uso da cobertura do jornal para as necessidades pessoais dos editores [...]; a mistura de recursos, que fazia um fotógrafo do jornal tirar a foto para o cartão de Natal do dono; a vergonhosa disposição de dar aos anunciantes (e aos diletos do dono) acesso privilegiado às páginas do jornal." (FULLER, 1996, p. 197)

Fuller rejeita a noção segundo a qual as corporações de capital aberto tenham mantido margens de lucro maiores do que as empresas familiares, drenando assim recursos que deveriam ser investidos em qualidade. De acordo com o autor, nos anos 20, quando The Herald Tribune, então pertencente ao coronel Robert R. McCormick, se tornou um jornal global, com correspondentes no mundo todo, e criou a edição rodada em Paris, gerou mais lucros por dólar investido do que em qualquer outro período posterior, incluindo a fase de redução de custos e introdução das práticas corporativas, nos anos 80 . O lucro operacional atingiu $29,8 \%$ em 1929. Depois disso, seu recorde foi de $24,6 \%$. $O$ que dá essa impressão de que as corporações de capital aberto são mais obsessivas na obtenção de lucro do que as empresas de propriedade particular ou familiar, acha Fuller, é que os executivos dessas corporações falam mais abertamente - e com mais freqüência - do tema lucratividade do que os donos de jornais. $O$ que não quer dizer que esses últimos ganhassem ou ganhem menos dinheiro. 
Jornalistas, assinala o autor, tendem a achar que sua profissão e o negócio dos jornais são diferentes dos outros. E que lucratividade é uma questão que não deve entrar nas suas preocupações. Ao contrário, lembra ele, a saúde financeira é a premissa do jornalismo independente. E donos de jornais, assim como os investidores em companhias de capital aberto, devem ter o mesmo interesse básico na lucratividade e no retorno de seus investimentos. Sejam pertencentes a empresas familiares ou a companhias de capital aberto, jornais têm de fazer investimentos e gastos que façam sentido economicamente - sob pena de perecerem ou de perderem sua independência. (FULLER , 1996, p. 208) No Brasil, como vimos no item anterior, os três diretores de redação manifestam o desejo de buscar um equilíbrio entre um passado de desprezo pelos fundamentos da boa gestão e da responsabilidade contábil, de um lado, e a compreensão de que o jornal é um negócio distinto de outros, que não pode ser visto apenas pelo prisma contábil. Os três concordam, ademais, que empresas jornalísticas subordinadas a executivos que não pertencem a esse setor, excessivamente preocupados com números, numa escala de tempo muito curta, podem ser daninhos para os jornais. ${ }^{47}$

Nos Estados Unidos, o processo de aquisição dos jornais de empresas familiares por companhias de capital aberto - com sua urgência por resultados contábeis imediatos - teve lances traumáticos. Meyer cita como exemplo o jornal The Des Moines Register. Quando a família Cowles, de Minneapolis, o vendeu à Gannett Company, em 1985, o jornal tinha uma margem de lucro operacional de 10\%, embora fosse dono do mercado de todo o Estado de lowa. Os executivos da Gannett consideraram que a influência em todo o Estado não tinha valor econômico e reduziram a circulação para a área que atendia aos anunciantes, em Des Moines. Duas das cinco sucursais do jornal no interior foram fechadas. A margem de lucro operacional subiu rapidamente para $25 \%$.

Charles Edwards, diretor-responsável do jornal durante a transição, resumiu assim os efeitos das mudanças:

Todas essas coisas, em si mesmas, como medidas individuais, não seriam necessariamente devastadoras para a qualidade ou para a capacidade do jornal de fazer bom jornalismo. Mas, coletivamente, tiveram um enorme

\footnotetext{
${ }^{47}$ Cf. entrevistas com os diretores, em Anexos.
} 
impacto. Com o tempo, não tivemos mais a capacidade e os recursos para fazer o trabalho que fazíamos antes. ${ }^{48}$

Exemplos assim não são incomuns. W. Davis Merritt, ex-editor do The Wichita Eagle, conta que, em meados dos anos 90, o grupo Knight Ridder, proprietário do título, pediu que o jornal aumentasse seu lucro operacional para $23,5 \%$. Os editores concluíram que a única forma de alcançá-lo seria cortando a circulação em 10 mil exemplares, reduzindo a presença do jornal na região a oeste de Wichita. "Tivemos de dizer a 10 mil pessoas que estavam comprando e lendo nosso jornal: 'Nós não vamos deixar você comprar mais o nosso jornal'", relata Merritt. ${ }^{49}$

São situações nas quais os jornalistas em cargos de direção se sentem impotentes. Diretores das áreas comercial e financeira chegam às reuniões com tabelas e gráficos preparados em power point e provam, de forma matematicamente incontestável, a necessidade de cortar custos na área editorial, na distribuição e na circulação, para manter os números no azul. Diretores de redação, de sua parte, lidam com perdas e ganhos intangíveis, não têm tempo nem costume de preparar power points, e têm de apelar para seu prestígio - ou para a ameaça de ir embora - para não perderem todas as batalhas.

A transição na forma de gestão encerra também mudanças de cultura para os jornalistas em cargos de comando. Cabe aos diretores de redação convencer as outras áreas da empresa que é com mais jornalismo, e não com menos, que os jornais devem enfrentar os desafios impostos pela concorrência dos outros meios, pelas inovações tecnológicas e pela mudança nos hábitos de leitura. Para isso, têm de se munir de instrumentos gerenciais para a negociação cotidiana com os outros departamentos. Têm de "falar a língua deles". A elaboração desses instrumentos é o nosso próximo tema.

\footnotetext{
${ }^{48}$ Declaração durante o debate "Are the demands of Wall Street trumping the needs of Main Street?", em Miami, 8/8/2002, citado por MEYER, 2004, p. 12

${ }^{49}$ Relato feito em seminário na Escola de Jornalismo e Comunicação de Massa da

Universidade da Carolina do Norte, Chapel Hill, em 22/4/2002, citado por MEYER, p. 12-13.
} 


\section{Aferição de valores intangíveis}

Alguns autores americanos têm-se esforçado, nos últimos anos, a criar instrumentos para medir os efeitos benéficos de bens intangíveis, como a qualidade, a credibilidade e a influência, sobre a circulação, a penetração e a lucratividade dos jornais.

Meyer lançou as bases do que ele chamou de "modelo de influência" (2004, p. 21-27). O autor examinou pesquisas feitas pela Fundação Knight em 23 comunidades onde o grupo Knight Ridder já possuiu ou ainda possui jornais. Mesmo depois de sua venda, a fundação mantém a série histórica, pesquisando a mesma lista de jornais. Uma das perguntas feitas aos entrevistados em 1999 e 2002 foi: "Por favor, defina quanto você acha que pode acreditar em cada uma das seguintes organizações de notícias que vou descrever. Primeiro, o jornal diário local com o qual você é mais familiar: você diria que acredita em quase tudo o que ele diz, na maioria das coisas que ele diz, em apenas algumas ou em quase nada do que ele diz?"

Como dados sobre lucratividade são difíceis de obter, Meyer cruzou o dado da credibilidade com o da circulação. Uma das vantagens desse critério, estima 0 autor, é que a circulação está menos subordinada a variações de ciclos econômicos do que o lucro. Para ajustar o dado aos tamanhos diversos de mercados, o autor dividiu a circulação pelo número de domicílios existentes no mercado. Como a definição de mercado é muito vaga, sua abrangência variando de jornal para jornal, Meyer restringiu a medição ao condado onde o jornal tem a sua sede. "Não conheço nenhum jornal importante que seja ambivalente sobre a circulação em seu condado", pondera. Meyer fez ainda um terceiro ajuste. Como a penetração dos jornais varia de mercado para mercado, ele criou um índice para comparar o desempenho dos jornais em sua própria série histórica, usando os dados de tiragem de 1995, 2000 e 2003 do Audit Bureau of Circulations ( $A B C)$, o equivalente americano do Instituto Verificador de Circulação (IVC). A esse índice, ele deu o nome de "robustez da penetração". "A penetração declinou em quase todos os lugares", constata 0 pesquisador. "Mas faz sentido chamá-la de robusta quando seu valor no Tempo 2 é uma proporção relativamente alta de seu valor no Tempo 1." 
Dos 23 jornais estudados, 21 dominam seus mercados, embora em vários desses condados haja mais de um jornal influente e, portanto, o jornal estudado não exerce monopólio.

Meyer notou que o índice de credibilidade de um mesmo jornal pode variar de forma expressiva entre as duas medições, de 1999 e 2002. Controvérsias locais ou a cobertura de grandes eventos podem ter causado essas variações. Assim, para atenuar o efeito dessas variações, ele adota uma média entre as duas medições.

Cruzando os dados, Meyer concluiu que a credibilidade dos jornais explica $31 \%$ da variação na robustez de sua penetração. "Credibilidade e robustez de penetração estão fortemente ligadas", conclui o autor. "Quando uma aumenta, a outra também aumenta."

Uma outra correlação encontrada foi entre o tamanho do mercado e a credibilidade: quanto menor o primeiro, maior a segunda. Para Meyer, esse dado corrobora a tese do sociólogo Richard Maisel, autor de The decline of mass media ${ }^{50}$, segundo a qual os meios de comunicação dirigidos a audiências menores têm maior êxito.

Meyer conduziu também um estudo específico sobre a correlação entre credibilidade e precisão na informação. Para isso, aplicou questionários, por dois anos consecutivos, em 5.136 pessoas que tinham sido fontes de informações em matérias de 22 jornais em 17 mercados de regiões metropolitanas. Meyer classificou os erros em objetivos (hard), matemáticos e subjetivos (soft). A proporção encontrada foi a seguinte:

\footnotetext{
${ }^{50}$ Publicada em Public Opinion Quarterly, edição do verão de 1973. Citada por MEYER, 2004, p. 2.
} 
TABELA 7 - Resultados de questionários

\section{Erros objetivos}

Grafia do nome

Outro erro ortográfico ou tipográfico......................................................10\%

Cargo

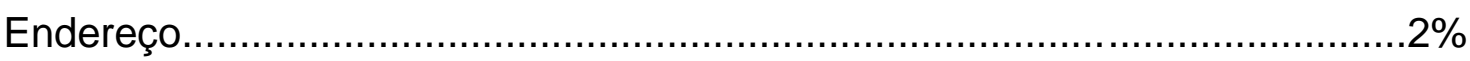

Idade

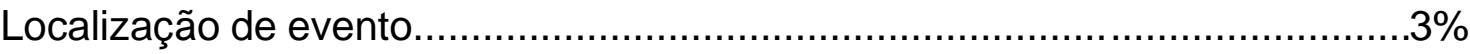

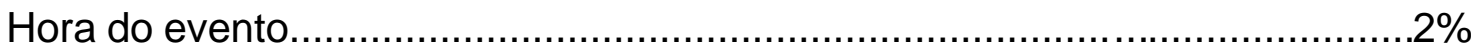

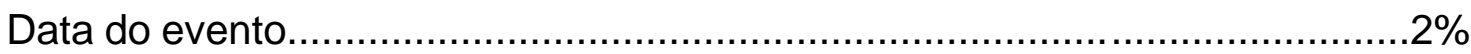

\section{Erros matemáticos}

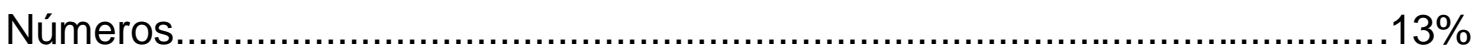

Uso ou interpretação de números.........................................................13\%

Erros subjetivos

Frases entre aspas distorcidas ou fora de contexto....................................21\%

Entrevistas distorcidas ou fora de contexto ............................................14\%

Não fui identificado da maneira que queria................................................11\%

Referências gratuitas a minha raça ou aparência..........................................2\%

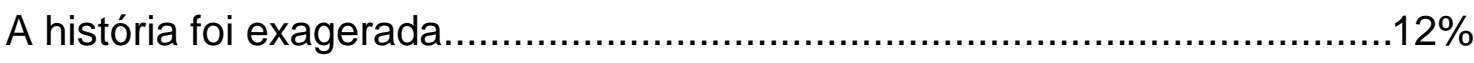

O tratamento foi sensacionalista.............................................................

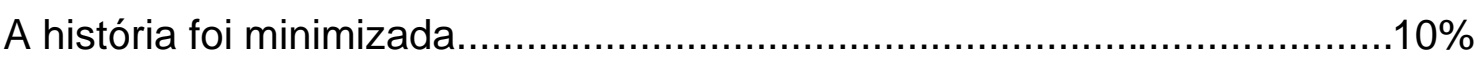

Outros (erros subjetivos).....................................................................

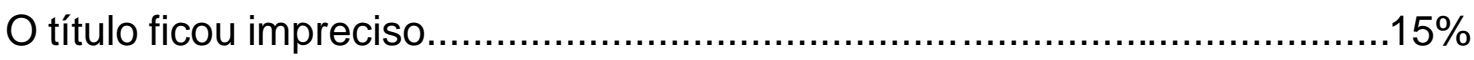

Erros de citação entre aspas...............................................................21\%

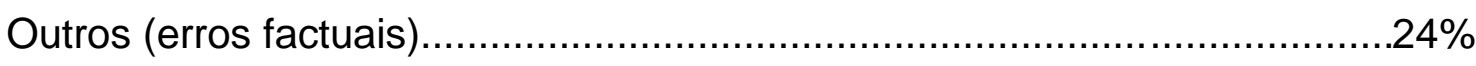


$\mathrm{Na}$ avaliação das fontes, $21 \%$ das matérias tinham pelo menos um erro objetivo; 18\%, pelo menos um erro matemático; e 53\%, pelo menos um erro subjetivo. Somando as três categorias, havia pelo menos um erro em $59 \%$ das matérias.

No questionário, também se pediu às fontes que dessem uma nota de 1 a 7 para os respectivos jornais, nos seguintes quesitos: justo/injusto; factual opinativo; parcialisento; confiávelnão-confiável; separa fato de opinião/mistura fatos e opiniões; sensacionalista/não-sensacionalista.

Cruzando os dois conjuntos de dados, Meyer mediu a correlação entre cada tipo de erro e o grau de confiança que os jornais inspiram. E constatou que erros objetivos têm peso de $1 \%$ sobre a confiabilidade; erros matemáticos, de $5 \%$; e erros subjetivos, de $18 \%$.

Meyer cruzou então os resultados de sua pesquisa com os de uma outra, feita pelo grupo Knight Ridder, nas mesmas comunidades. E verificou que os dados apurados eram consistentes com os de sua pesquisa. Com isso, concluiu que a percepção das fontes - também chamadas de "formadores de opinião" - é semelhante à do público em geral.

O cruzamento permitiu determinar que, nas comunidades cujos jornais têm mais erros do que a média, os cidadãos confiam menos na imprensa. Dessa maneira, Meyer concluiu que a propensão natural de mercados menores a confiar mais nos seus jornais não é o único fator que determina o índice de credibilidade. Fatores concretos, como a precisão da informação, pesam nessa avaliação. (MEYER, 2004, p. 86 e ss.)

Em termos práticos, "credibilidade" e "precisão", as variáveis aferidas, inscrevem-se no quadro geral dos esforços em prol da "qualidade" de um jornal. Em termos mais práticos ainda, os investimentos em qualidade não podem ser infinitos. Todo jornal tem de encontrar um ponto de equilíbrio entre sua lucratividade e seu investimento em qualidade. Ao trabalhar em seu "modelo de influência", Meyer parte do princípio de que a qualidade produz retorno financeiro maior que o investimento até um certo ponto. "É vital para um gerente - ou um investidor", escreve Meyer, "saber se esse ponto se aproxima, se o alcançou ou se o excedeu." O autor imagina uma curva no formato de um 
sino, na qual a qualidade produz mais lucro até um determinado ponto, a partir do qual o lucro começa a declinar. $O$ investimento inicial na qualidade de um jornal, observa Meyer, significa apenas custo. $O$ retorno financeiro vem mais tarde, depois que a influência do jornal se acumula. Igualmente, há um lapso quando a qualidade se degrada. Leitores e anunciantes continuam recorrendo ao jornal, por hábito, um bom tempo depois que os motivos originais pelos quais eles optaram por ele cessaram de existir.

Um jornal está em apuros quando seus donos acreditam que ele ultrapassou o sweet spot [o ponto em que investir em qualidade dá retorno] e está na parte descendente da curva. Se eles tiverem realmente ultrapassado o ponto do retorno declinante, eles estão certos em cortar a qualidade e voltar para um nível que faz sentido economicamente. Mas, e se eles estiverem do lado ascendente [da curva]? Nesse caso, os cortes de qualidade os empurrarão para o precipício até a destruição final." (MEYER, 2004, p. 31-2)

Sánchez-Tabernero nota que a vinculação entre qualidade e satisfação do consumidor, elementar em todos os ramos, parece menos óbvia no mundo da comunicação (2000, p. 108). Tanto que veículos populares, sensacionalistas, que em muitos casos requerem bem menos investimento em qualidade do que os veículos mais sérios, em geral têm mais audiência e, em alguns casos, mais rentabilidade. $\mathrm{Na}$ imprensa londrina, por exemplo, dos 14 milhões de exemplares diários, menos de um quarto corresponde aos chamados "jornais de qualidade": The Times, The Guardian, The Daily Telegraph, The Independent e The Financial Times. Mais de $75 \%$ da tiragem é dos jornais sensacionalistas, liderados por The Sun e The Daily Mirror. Seguindo a fórmula dos três "esses" - sangue, sexo e sensacionalismo -, escreve SánchezTabernero, em espanhol, The Sun vende mais exemplares do que todos os jornais de qualidade juntos.

Esse êxito, argumenta o autor, não elimina o fato de que a qualidade é um requisito de sobrevivência noutros nichos, como o dos jornais de qualidade:

Na prática, a razão pela qual The Wall Street Journal, The Financial Times, Nihon Keizai Shimbun, The Economist e as agências Reuters e Bloomberg dominam o fluxo de informação econômico-financeira e conseguem muitos clientes em todo o mundo radica na precisão, contextualização e rapidez das mensagens que transmitem. (SÁNCHEZ-TABERNERO, 2000, p. 108)

Os investimentos em qualidade têm os seguintes retornos, enumera SánchezTabernero: favorece incrementos de consumo; permite aumentar o preço; gera barreiras de entrada frente a possíveis compeditores. Noutras palavras, 
aumenta o investimento necessário para quem quiser entrar no mercado para disputar com as empresas já consolidadas. (op. cit., p. 138)

Sánchez-Tabernero conclui, sobre a relação entre qualidade e satisfação do cliente, nos meios de informação: 1) a qualidade implica adequação a demandas e necessidades do público; 2) requer investir a maior quantidade de recursos disponível na elaboração de serviços e produtos; 3) alguns produtos informativos e de entretenimento de qualidade alcançam altos níveis de consumo; 4) em alguns nichos, o alto nível de qualidade é requisito de sobrevivência; 5) alguns formatos parecem incompatíveis com a qualidade, ou ao menos mais apropriados à simplificação das mensagens.

O que procuramos mostrar, neste item, é que as dificuldades de tradução de valores intangíveis em linguagem contábil não são um problema incontornável no diálogo entre a redação e os outros departamentos da empresa jornalística. É possível defender, de forma objetiva, os investimentos na qualidade e na influência como ativos do jornal e como fatores de rentabilidade da empresa. $E$ o investimento em qualidade e influência são as respostas do jornal ao acirramento da concorrência, à mudança dos hábitos de leitura e aos desafios impostos pelas inovações tecnológicas. Esse novo ambiente requer, também, uma mudança de paradigma, na auto-imagem do jornal acerca de sua posição no mercado e de seu papel na sociedade. É o que veremos no próximo item.

\section{Mudança de paradigma}

O longo declínio vivido pelos jornais desde o advento de meios de comunicação de massa que lhes passaram a fazer frente, no último meio século, encerra, em última análise, uma mudança de paradigma, no que se refere às suas posições de mercado e às suas margens de lucratividade. Meyer (2004) tem uma analogia para explicar como os jornais costumavam ganhar dinheiro. No século 19, os condes de Savoy ergueram um castelo sobre a Rocha de Chillon, na margem leste do Lago Genebra, na Suíça. Com o lago a oeste e uma montanha a leste, o castelo controlava o tráfego de norte a sul da Suíça, e a família cobrava um pedágio pela passagem. A alternativa ao pedágio seria atravessar o lago a nado ou escalar a montanha. Por séculos, os 
senhores de Savoy e seus herdeiros desfrutaram desse monopólio. Hoje em dia, no entanto, os viajantes podem usar estradas alternativas, atravessar 0 lago com barcos a motor ou passar voando de avião.

Durante gerações, diz Meyer, os donos de jornais americanos foram como a família Savoy. Seus jornais exerceram monopólio como pedágios através dos quais a informação passava entre os anunciantes e seus clientes e fregueses. "Na maior parte do século 20, esse gargalo foi virtualmente absoluto", registra Meyer. "Ser dono de um jornal era como ter o poder de cobrar um imposto sobre a venda." Jornais de tamanho médio nos Estados Unidos - que, em circulação, correspondem aos grandes jornais brasileiros -, em mercados nos quais exerciam monopólio, acostumaram-se a margens de lucro de $20 \%$ a $40 \%$. A margem média no varejo é de $6 \%$ a $7 \%$. Supermercados prosperam com margens de lucro de $1 \%$ a $2 \%$.

Essa cultura de dinheiro fácil criou maus hábitos. Se o dinheiro entra, independentemente do tipo de produto que você entrega, você se orienta pela produção, em vez de se orientar pelo cliente [...]. Se sua posição de mercado é forte, você pode baratear o produto e aumentar os preços ao mesmo tempo. A inovação ocorre, mas é freqüentemente orientada a tornar o produto mais barato, em vez de torná-lo melhor. (MEYER, 2004, p. 35)

Mas novas tecnologias criaram caminhos alternativos àquela estrada pedagiada, oferecendo alternativas para os anunciantes se comunicarem com seus públicos: televisão, publicações especializadas, mala direta e, agora, a internet. Para Meyer, não é o fim dos jornais. Haverá espaço para eles, num ambiente de não-monopólio. Não serão tão lucrativos, mas isso é um problema para seus donos e acionistas, acha o autor. Segundo ele, se os jornais se mantiverem num patamar de margem lucro de $6 \%$ a $7 \%$, que é o normal para o varejo, haverá empresários dispostos a produzi-los, e "a sociedade será tão bem servida quanto ela é hoje." (Id.)

Segundo números da empresa de consultoria em gestão McKinsey, citados por Sandro Vaia ${ }^{51}$ em novembro de 2005, a rentabilidade média dos jornais no mundo era de $25 \%$. E a dos jornais brasileiros, entre $10 \%$ e $20 \%$ - o patamar no qual o Estado se incluía. Portanto, a situação é mais que confortável, em contraste com o cenário traçado por Meyer.

\footnotetext{
${ }^{51}$ Em entrevista ao autor, cuja íntegra se encontra em Anexos.
} 
Isso, com relação à parte empresarial do jornal.

Por outro lado, novos paradigmas também surgem para o produto jornal e para o fazer jornalismo. Da mesma maneira que ofereceram novos canais entre anunciantes e clientes, a televisão e a internet também introduziram maneiras instigantes de relatar as notícias. Os jornais têm tido dificuldade de aproveitar suas eventuais vantagens comparativas, como ilustram os resultados da pesquisa qualitativa citada no capítulo 4, e esta análise de Carlos Chaparro, colunista do site Comunique-se:

Sem capacidade de oferecer novidades no plano da informação, os jornais diários ainda não encontraram formas criativas de potencializar e tirar proveito das aptidões interpretativas que só os meios impressos possuem. Assim, limitado tecnologicamente pelo ciclo de periodicidade de 24 horas, na rabeira da notícia, o jornalismo diário impresso repete conteúdos pensados e produzidos para alcançar o mundo pela televisão. No show do noticiário, entretanto, a festa é da televisão, grande beneficiária das tecnologias de difusão. A televisão tem a capacidade da difusão instantânea e universal, e por isso para ela se organizam os programas, os cenários, as cenas, as cronologias, os movimentos, as indumentárias, as falas e o gestual. [...] Porque tudo pode ser visto e ouvido pela TV na hora em que as coisas acontecem [...], desapareceu o intervalo de tempo entre o fato e a notícia, dentro do qual o jornalismo antigamente trabalhava [...]. É um mundo novo. (CHAPARRO, 2004)

Em larga medida, os jornais ainda seguem sendo feitos como se os leitores não tivessem sido bombardeados, na véspera, com notícias sobre os fatos, à medida que iam ocorrendo. As notícias são em geral apresentadas como novidade, provocando no leitor uma sensação de déjà vue. Aquilo em que os jornais se diferenciam da internet, que Chaparro chama de "aptidões interpretativas", ainda é pouco explorado pelo meio. A imensa maioria dos textos é factual, freqüentemente escrita às pressas, no afã de contar ao leitor o que aconteceu na véspera. As redações não estão estruturadas para oferecer, com qualidade, o contexto e a análise da notícia, que são os atributos que diferenciam o jornal dos outros meios.

Novos paradigmas no negócio e no jornalismo permeiam as discussões sobre como devem reagir os jornais diante do acirramento da concorrência, das inovações tecnológicas e das mudanças nos hábitos de leitura. A seguir, as visões dos diretores de redação dos três grandes jornais brasileiros sobre esses novos paradigmas, e como eles estão respondendo ao "mundo novo". 


\section{CAPÍTULO 3 - A RESPOSTA DOS JORNAIS}

Os diretores de redação dos três jornais que são objeto deste estudo apresentaram visões bastante semelhantes entre si, em entrevistas ao autor, realizadas em novembro de 2005. Apesar de haver particularidades que diferenciam a situação de cada jornal, o diagnóstico que fazem da posição do meio jornal frente aos outros meios e suas opiniões sobre como eles devem reagir à concorrência, às inovações e aos novos padrões de leitura têm muito mais pontos em comum do que divergências. Essa concordância reforça a premissa deste trabalho, de que o Globo, a Folha e o Estado podem ser vistos em conjunto, quando se analisam os grandes jornais brasileiros na sociedade da informação.

Dos três jornais, o Estado é o mais antigo. Foi fundado em 1875, por um grupo de intelectuais paulistas, engajado no fim do regime de escravidão e favorável à introdução da República. A família Mesquita, que assumiu o controle em 1902, está na quarta geração à frente do jornal. Em meio a um processo de renegociação de sua dívida, em 2003, a família concordou em deixar a gestão das diversas unidades do grupo, recuando para o Conselho de Administração. A exceção é Ruy Mesquita, que permaneceu no cargo de diretor-responsável, no qual responde pela opinião do jornal. Com isso, a família se mantém associada à principal marca da identidade do jornal. De resto, profissionais contratados passaram a ocupar os cargos de comando da empresa. Suas decisões mais importantes têm de passar pelo crivo dos 16 acionistas, que continuam sendo os integrantes da família Mesquita.

Quando concedeu a entrevista ao autor, Sandro Vaia, então diretor de redação do Estado, vinha de promover, em dezembro de 2005, uma reforma gráfica radical no jornal, que lhe tirou $\mathrm{o}$ ar tradicionalmente pesado e sisudo, dando-lhe uma feição moderna e mais leve. Vaia, que deixaria o cargo em outubro de 2006, sendo substituído por Ricardo Gandour, investiu em novos cadernos, como o dominical Aliás, que resume e aprofunda os temas da semana, e o suplemento de gastronomia Paladar. Deu maior peso às reportagens especiais e maior agressividade ao jornal. O Estado teve, em 2005, uma tiragem média diária de 231 mil exemplares, que o coloca em quarto lugar no ranking nacional. 
O Globo foi fundado em 1925 por Irineu Marinho, e está na terceira geração da família. Os herdeiros são três irmãos, que dividem assim a direção das Organi zações Globo: Roberto Irineu Marinho é presidente da Globopar, o que o torna o gestor do grupo; João Roberto Marinho é responsável pela área editorial; e José Roberto Marinho cuida do relacionamento da empresa com a sociedade. Desde meados dos anos 90, o prnal é dirigido por profissionais contratados.

O atual projeto gráfico do Globo data de 1995, quando o jornal antecipou uma tendência, ao dedicar suas edições diárias a um número menor de temas, investindo neles com textos mais longos e várias matérias de apoio, em vez da cobertura fragmentada, com matérias pequenas sobre um número maior de assuntos, que dominava os jornais na época. Com o definhamento do Jornal do Brasil, a partir dos anos 90, o Globo ficou sem concorrente no Rio. Sua tiragem média, em 2005, foi de 275 mil exemplares, que o coloca em segundo ou terceiro lugar, dependendo das oscilações da tiragem do Extra, jornal popular do Rio, também pertencente às Organizações Globo, que teve uma circulação média diária de 274 mil exemplares naquele ano.

A Folha da Manhã, o jornal precursor da Folha de São Paulo, também surgiu em 1925. Octavio Frias de Oliveira, o seu atual proprietário, assumiu o controle do jornal em 1962, junto com Carlos Caldeira Filho. Dos três jornais, a Folha é a única que continua sendo gerida, no seu dia-a-dia, pelos herdeiros do dono, os irmãos Otavio Frias Filho e Luís Frias. Otavio é o diretor editorial e Luís, presidente da empresa.

Nos anos 80, a Folha passou por arrojadas reformas, com base em um projeto editorial que modernizou o jornal. A Folha inovou com o seu Manual de Redação, que impôs normas de conduta dos jornalistas, a mais famosa delas a de "ouvir o outro lado". Também introduziu a divisão do jornal em cadernos temáticos e instituiu a figura do ombudsman, uma espécie de ouvidor. Sua última reforma gráfica foi feita em maio de 2006, mas com alterações superficiais, seguindo o padrão introduzido nos anos 80. A Folha ultrapassou em tiragem o seu concorrente direto, o Estado, e consolidou-se, nos últimos anos, como o jornal de maior circulação do país, com 308 mil exemplares de média diária, em 2005. 
As entrevistas com os três diretores foram de roteiro aberto, fincadas, porém, no tripé que sustenta este trabalho: a reação dos jornais à mudança nos hábitos de leitura, ao acirramento da concorrência com outros meios e às inovações tecnológicas. Os três diretores avaliam que os jornais não regressarão aos patamares de circulação registrados nos anos 90 , quando a Folha se aproximou do 1,5 milhão de exemplares, em suas edições dominicais, seguida pelos dois concorrentes. Aquela situação é vista pelos três como artificial, por causa dos brindes - coleções de livros, filmes, CDs - que acompanhavam os jornais e ficaram conhecidos como "anabolizantes". O termo se refere às drogas usadas por freqüentadores de academias de ginástica para aumentar o volume de seus músculos. $\mathrm{Na}$ visão de Sandro Vaia, aquela política de marketing criou uma distorção na série histórica da circulação dos jornais:

Não vi ainda nenhum estudo concreto - nem aqui na nossa Circulação consegui isso - que expurgasse esses efeitos, para saber exatamente quanto foi a queda efetiva de circulação do jornal. Em termos nacionais, ela não caiu. Nos grandes jornais, há esse defeito de metodologia que inclui essa bolha que não sei como se fará para expurgar, nem se os departamentos de circulação têm capacidade de fazer isso, de localizar quando começou, quando chegou no auge, quando voltou a zero, para retomar o período verdadeiro.

Para Rodolfo Fernandes, os anabolizantes induziram a comprar os jornais pessoas que não se incluíam no seu público "essencial". Ele não acha que a política tenha sido de todo condenável, porque os brindes oferecidos tinham alguma relação com o negócio dos jornais, como coleções de literatura brasileira e enciclopédias, por exemplo. "Ninguém estava vendendo panela", diz ele. Um retorno a essa estratégia, no entanto, foi descartado pelos três diretores de redação. "A política de promoções se esgotou", resumiu Otavio Frias Filho.

O que não quer dizer que os jornais estejam condenados, no curto prazo, a uma curva declinante de circulação. Ao contrário, no momento em que foram realizadas as entrevistas, em novembro de 2005 , os três jornais celebravam uma recuperação de suas tiragens. No caso do Estado, essa recuperação não se registrou na circulação diária de 2005, porque começou no fim do ano, e não foi capaz de reverter a média anual. 
A circulação média diária do Estado foi de 341.300 exemplares em 2001. Em 2004, ela havia baixado para 233.471 exemplares - o que representa uma queda de $31 \%$ no período. Em 2005, o Estado registrou circulação média diária de 230.859 exemplares - queda de $1 \%$

.Nos outros dois jornais, a recuperação também se consolidou no fim do ano, e por isso o seu impacto sobre a média anual não foi tão robusto.

A circulação média diária da Folha era de 399.654 exemplares, em 2001. Em 2004, havia caído para 307.703, em 2004 - uma queda de 23\%. Em 2005, sua tiragem foi de 307.937 exemplares por dia.

A circulação média do Globo diminuiu de 296.272 exemplares por dia, em 2001, para 257.451, em 2004 - queda de 13\%. Em 2005, a circulação subiu para 274.934 exemplares, o que representa um aumento de $6 \%$ sobre o ano anterior. $^{52}$

Ainda assim, os três diretores de redação não contam com aumentos de circulação. "Acho que é uma tendência mais ou menos inexorável", disse Sandro Vaia, referindo-se à queda de circulação. "Acho que jornal não vai ser mais mídia de massa", observou Rodolfo Fernandes. A circulação, diz ele, "estabilizourse num nível bem inferior ao de anos atrás. Mas talvez fosse irreal a circulação de anos atrás."

Como vimos no capítulo anterior, dois fatores estruturais concorrem para a queda de circulação dos jornais. O primeiro é a diminuição do tempo dedicado à leitura; o segundo, o acirramento da concorrência dos outros meios. A seguir, exporemos a visão dos diretores de redação sobre esses dois aspectos, e mais a sua reação ao terceiro elemento que compõe o tripé deste estudo: a inovação tecnológica.

\section{Queda na leitura}

Conforme vimos no capítulo anterior, em 2002, os leitores de jornais brasileiros dedicavam 51 minutos por dia à leitura dos jornais, de segunda-feira a sábado, e 56 minutos, aos domingos. Em 2005, esse tempo havia caído para 46

\footnotetext{
${ }^{52}$ Fonte: Instituto Verificador de Circulação (IVC). Disponível no site da Associação Nacional de Jornais (ANJ), no endereço: http://www.anj.org.br/?q=node/177. Acessado em 12/12/2006.
} 
minutos de segunda a sábado e para 51 minutos, aos domingos. ${ }^{53}$ Ano após ano, tem caído também o número de exemplares por adultos na população brasileira, assim como na maior parte dos países cujo dado está disponível para a Associação Mundial de Jornais. No Brasil, havia 64,2 exemplares de jornal para mil habitantes adultos, em 2001. Em 2005, esse número havia caído para 45,3 exemplares por mil habitantes adultos - o que representa uma queda de $29 \%$.

No que parece ser um problema com forte componente geracional, os diretores de redação identificam uma dificuldade de atrair os jovens para a leitura dos jornais. Rodolfo Fernandes descreve assim o fenômeno:

Evidentemente a gente sente que tem um público jovem entrando aí que não se acostumou a ler jornal, que a gente não sabe o que eles vão fazer quando começarem a trabalhar e precisarem da informação. Porque, em última análise, as pessoas lêem jornal porque precisam da informação, aquilo é relevante no contexto social delas. Quando meu filho de 15 anos de idade, ou o pessoal que está com 20 anos de idade hoje, entrar no mercado de trabalho, precisar desse tipo de informação, onde eles vão buscar? Eu me surpreendo com meu filho de 17 anos de idade, que às vezes chega em casa e já sabe de um monte de coisa. Ele leu aí, vasculhando na internet. Talvez ele não tenha a visão geral de um tema que hoje só o jornal realmente pode proporcionar.

Aqui, uma questão crucial para o futuro dos jornais é se os jovens, quando amadurecerem, adquirirão o hábito da leitura, ou se continuarão desvinculados dos jornais, o que selaria o destino da indústria. Não há uma resposta definitiva para essa questão. Rodolfo Fernandes acredita que esse vínculo entre os jovens e os meios digitais continuará quando eles deixarem de ser jovens, criando uma geração de não-leitores de jornais:

Eu acho que não é mais porque eles são jovens, vão envelhecer e vão ler jornal. Eu acho que, hoje, o fenômeno digital é uma coisa avassaladora.

A fórmula para atrair os jovens ainda não foi encontrada, diz o diretor de redação do Globo, que define o problema como "o grande desafio" ao "futuro empresarial desse negócio". Segundo ele, em várias partes do mundo, os jornais têm feito suplementos e as empresas de comunicação, lançado tablóides gratuitos, sem resultados.

\footnotetext{
${ }^{53}$ Pesquisa realizada anualmente pelo Ibope Monitor, divulgada no site da Associação Nacional de Jornais, no endereço: http://www.anj.org.br/?q=node/179. Último acesso: $13 / 12 / 2006$
} 
Otavio Frias Filho acredita que haja "um pouco de verdade" nas duas teorias a de que os jovens, ao deixar de ser jovens, se tornarão leitores de jornais, e a de que isso não acontecerá. Ele salienta que os jovens, em alguns sentidos, estão amadurecendo mais tarde do que antes. Alguns deles deverão se tornar leitores de jornais, mas não todos, nem a maioria:

Acho que não é mero wishful thinking alimentar a expectativa de que uma parte desses jovens que hoje parece refratária à leitura dos jornais será um componente de late comers num universo futuro de leitores de jornal. Agora, acho que é necessidade de realismo reconhecer que muito provavelmente isso valha apenas para uma parte dos jovens. E provavelmente uma parte minoritária.

O diretor de redação da Folha aponta, também, para o fato de que a internet contribui para um ressurgimento do hábito de leitura e de escrita, por causa dos emails, messengers e todas as formas de comunicação escrita que os meios digitais propiciam. Em última análise, grande parte da informação que se consome na internet vem em linguagem escrita.

Ainda assim, Otavio Frias Filho estima que os jornais continuarão seguindo a tendência, que vem desde os anos 80, de perder "massa de texto", e isso está relacionado, em parte, à mudança nos hábitos de leitura do jornal sobre papel:

É uma cultura visual, pela lei do menor esforço. As pessoas não têm tempo, não têm paciência. $O$ hábito adquirido de fazer o tipo de leitura mais tradicional, a figura clássica do sujeito que, na hora do café da manhã, pega os jornais, e vai ler meticulosamente página por página, e vai gastar duas horas, duas horas e meia lendo jornal, não existe mais, ou pelo menos está reduzida a um contigente minguante de leitores.

Por outro lado, a diminuição dos hábitos de leitura do jornal sobre papel não está ligada apenas a mudanças geracionais, mas, também, à abundância de ofertas de informações por outros meios, que atrai também adultos e leitores de jornais. A visão e a reação dos diretores de redação em relação a essa concorrência são o tema do próximo item.

\section{Acirramento da concorrência}

A queda na circulação dos jornais coincidiu, nos últimos anos, com o surgimento e expansão da internet, com o crescimento das TVs por assinatura, com o aumento do espaço dado ao jornalismo nas emissoras de rádio e com a criação, em 1998, de uma nova revista semanal de grande circulação no Brasil, 
a Época. Todos esses meios disputam o tempo e o dinheiro do público - dois bens finitos. Os três diretores de redação realçaram as qualidades do meio jornal frente a todos esses concorrentes. Mas admitiram que os jornais tendem a diminuir de tamanho e de circulação, e a concentrar-se naquilo que os diferencia dos outros meios: a contextualização, a análise e a qualidade da narrativa.

Além da diminuição nos hábitos de leitura, Otavio Frias Filho diz que os jornais devem diminuir de tamanho também por ser "muito cara a operação mecânica de fazer jornal'. Sandro Vaia vai na mesma direção: "Financeiramente, é insustentável fazer jornais enormes, [...] e grande parte da publicidade que sustenta os jornais provavelmente vai migrar para meios eletrônicos."

No caso do Globo, Rodolfo Fernandes tem dúvidas quanto à conveniência e à viabilidade de reduzir o volume de páginas do jornal:

Acho que chegou ao mínimo aqui. Por outro lado, você sente que às vezes 0 jornal é grande demais para quem está lendo. A pessoa não tem condição de ler tudo. Mas eu acho que o leitor do jornal não é leitor de tudo. Tem o que quer ler Economia, que quer ler uma boa Economia. O que quer ler Esporte, quer ler um bom Esporte. O que quer ler Política, quer ler uma boa Política. Então, como fazer um jornal menor, sem transformar uma dessas partes numa coisa tão rasa que não vai interessar ao leitor identificado com aquele assunto? Se você diminuir mais o Esporte, aquilo é uma porta de entrada do jovem, então o jovem não vai mais ler jornal. Se você diminuir Economia, as pessoas que são influentes na economia, os economistas, os empresários vão deixar de ler. Se você diminuir a Política, aquilo é o maior fator de influência do jornal. É um cobertor curto.

Os três diretores de redação descartaram a possibilidade de adotar o formato tablóide, como fizeram os chamados jornais de qualidade da Inglaterra. Lá, já existia uma tradição dos tablóides sensacionalistas, e o hábito de ler o jornal no metrô e no ônibus, para o qual o formato menor é mais confortável, observou Sandro Vaia. No Brasil, com exceção do Rio Grande do Sul, não há a tradição nem o hábito.

Mesmo reconhecendo uma migração da publicidade do jornal impresso para a internet, Sandro Vaia não acredita que a mídia eletrônica venha a substituir completamente o jornal. Em primeiro lugar, por causa das qualidades físicas do meio jornal: sua portabilidade e facilidade de manuseio. En segundo lugar, pela capacidade reflexiva dos jornais: "É difícil você tentar se aprofundar numa reflexão, numa análise, em um meio eletrônico. Você usa o meio eletrônico 
para hard news, para notícia rápida, curta, instantânea." Entretanto, diz Sandro Vaia, esse esforço de diferenciação requer que os jornais aperfeiçoem sua capacidade de contextualização e reflexão, em detrimento do factual:

O jornal de hard news desaparece, e passa a ser um jornal de análise, de comentário, para quem quer saber mais, para quem quer se aprofundar na informação. [...] Os jornais têm de se conscientizar de que não podem ficar repetindo, no dia seguinte, aquilo que todo mundo já sabe.

Além da reflexão e da contextualização, que "dão sentido" à notícia, Sandro Vaia também acredita fortemente na capacidade do jornal de, por meio da reportagem, "mostrar verdadeiramente o país em que a gente vive". O então diretor de redação do Estado criou a chancela "Retratos do Brasil" para reportagens especiais que mostram ângulos do que, no jargão, é chamado de "vida real":

Acho que é o caminho do jornal. Ficar no jornalismo declaratório, na repetição, no factual do dia anterior, é a morte certa. Não tem por que comprar jornal. As pessoas não se sentem obrigadas nem necessitadas de comprar jornal.

Otavio Frias Filho concorda que "os jornais precisam, na medida do possível, em algum grau, abandonar a cultura do 'aconteceu ontem', e investir mais em histórias próprias, [...] exclusivas, dar mais dimensão para a contextualização da notícia, mais visibilidade para aquilo no que os jornais são muito bons, que é a análise, opinião, crítica". Ele pondera que o "aconteceu ontem" continuará tendo certa importância para os jornais, para atender a "uma massa de pessoas" que reserva um momento do dia para se informar sobre o que aconteceu nas últimas 24 horas. São pessoas que não precisam das notícias em tempo real, que não são "consumidoras pesadas" de informação.

O diretor da Folha reconhece no jornalismo feito na internet vantagens como a instantaneidade e a rapidez, mas observa que, "em termos qualitativos, ele não sustenta uma comparação com o jornalismo dos jornais", que "continuam produzindo um tipo de jornalismo, comparativamente, muito qualificado".

Rodolfo Fernandes também é otimista quanto ao espaço reservado ao jornal: "Não consigo ver o fim do jornal, porque acho que o que o jornal faz não tem nenhuma outra mídia fazendo, e não vejo a internet nesse caminho". O diretor do Globo salienta o trabalho de edição feito pelo jornal, que ordena e hierarquiza a informação em um ambiente em que ela se encontra fragmentada, espalhada horizontalmente, nos meios digitais: 
A gente apura, está com 500 assuntos durante o dia, depois a gente vai refinando isso. Nas nossas reuniões de editores às 5 da tarde, isso já passa para 100 assuntos. Depois, a gente bota 10 na primeira página, dizendo: essa é a manchete, esse é o assunto mais importante, essa é a foto mais importante do dia, esses são os temas que nós entendemos que são os mais relevantes para você, leitor. [...] Basicamente, o que a gente faz é isso: peneirar o noticiário, contextualizá-lo, acrescentar ou a opinião do jornal ou o enfoque editorial que a redação vai dar. A partir daí, você dá ao leitor o seguinte: entenda o que aconteceu no mundo."

O jornal também se mostra capaz de fazer isso pelo seu nível de investimento em apuração, inexistente nos outros meios, concordam os diretores de redação. Rodolfo Fernandes cita um exemplo da época em que concedeu a entrevista: a explosão de violência nos subúrbios de várias cidades européias. Referindo-se a um conjunto de reportagens publicadas na véspera, 13/11/2005, no Globo, sobre as tensões sociais nesses países, o diretor de redação descreveu a estrutura por trás da operação:

O Globo está lá com correspondente na Bélgica, na Inglaterra, na Alemanha, na Espanha, então você tem condições de fazer no domingo um panorama gigantesco do que está acontecendo na Europa. Quando você vai ver isso na internet?

Graças a essa capacidade de apuração, os jornais se colocam à frente da televisão, um meio mais "quente", em tese. É o que argumenta Rodolfo Fernandes:

Se o jornal envelheceu, a televisão mais ainda, porque ela dá, às vezes, um ou dois dias depois notícias que os jornais já deram dias antes. Então, tenho muita dificuldade de ver a perda de relevância do que o jornal faz.

A concorrência das revistas semanais também não parece preocupar muito os diretores de redação. E eles rejeitam a possibilidade de seguir pelo caminho por elas trilhado, das concessões aos anseios dos leitores, expressos nas pesquisas qualitativas (ver o capítulo anterior).

Otavio Frias Filho lembra que a revista Época "desinflou", depois de ter tido um lançamento "espetacular", em 1998. O diretor de redação da Folha observa que a alta tiragem inicial de Época também foi "muito impulsionada por políticas de promoção, com uma série de concessões ao anunciante novo". Depois, seguiu uma curva descendente de circulação, observa.

O diretor da Folha admite que as revistas semanais possam ter tido um "desempenho comparativamente melhor" que o dos jornais. Mas argumenta que, em parte, isso se deu pela "inflexão abrupta" que realizaram, nos anos 90, 
para atender, "quase sem restrições", às demandas dos leitores por mais matérias sobre lazer, cultura do corpo, saúde e dietas, entre outras:

As revistas se curvaram, a meu ver, de forma muito acrítica, no limite até desfigurando a sua identidade como veículos de opinião, ditos de qualidade, com determinado compromisso com certas questões públicas, com sua própria tradição editorial. Tenho a impressão de que as revistas deixaram tudo isso um pouco em segundo plano para atender a demandas estritamente de mercado, num atendimento que me parece que foi automático, cego, acrítico. [...] As revistas se despolitizaram.

Os jornais não realizaram essa inflexão, nem pretendem realizá-la, pontuaram Otavio Frias Filho e Rodolfo Fernandes. O diretor de redação do Globo também critica a importância dada pelas revistas às matérias de comportamento, saúde e culto ao corpo:

É a fórmula que as revistas encontraram para vender mais, porque é o que o público está querendo. Mas, com isso, elas perderam relevância política e deixaram os jornais entrarem por esse caminho nas edições dominicais.

Rodolfo Fernandes avalia que as edições dominicais dos três grandes jornais são "muito melhores" que as de Veja, a revista semanal líder em circulação. "Os jornais aprenderam a fazer revista", disse ele, referindo-se às matérias especiais, "bossas", entrevistas e reportagens investigativas cuja apuração pode levar meses, "coisa que as revistas não fazem mais". Rodolfo Fernandes reconhece que Veja teve um papel importante na apuração dos escândalos de corrupção envolvendo o governo Lula, mas observa que, nos meses anteriores à eclosão desses escândalos, a revista havia perdido relevância. "Quem tem que se reinventar é a revista", disse o diretor de redação do Globo.

Entretanto, observa Otavio Frias Filho, os jornais "também vêm sendo contaminados" pelas demandas dos leitores, ainda que com uma disposição de fazer concessões muito menor: "Eu acho até bom que eles saiam da torre de marfim e prestem mais atenção àquilo que o leitor majoritário quer." O diretor de redação da Folha estima, de uma forma subjetiva, que o jornal atenda a apenas $20 \%$ dos seus leitores, ao se concentrarem nos "temas tradicionalmente nobres do jornalismo", como política, macroeconomia e internacional. Outros $80 \%$ do leitorado, calcula, "menos politizado", e com "menos paciência para ler jornal", faz uma leitura mais "utilitária", restrita a algumas seções e colunas. 
Assim como Sandro Vaia, Otavio Frias Filho também acha que os jornais devem se aproximar da "vida real do leitor". Ainda assim, ele rejeita o "atendimento cego" às demandas dos leitores, porque "tende a desfigurar a identidade do veículo ao longo do tempo", e isso seria prejudicial "não só sob o prisma do conceito de jornalismo", mas, também no longo prazo, no próprio desempenho econômico dos jornais.

Em resumo, os diretores de redação acreditam que é com mais qualidade que os jornais devem enfrentar a concorrência e a queda da leitura. Eles devem aperfeiçoar-se naquilo em que são melhores que os concorrentes, como a análise, a contextualização e a narrativa. Dentro dessa estratégia, a notícia perde alguma ênfase, mas os jornais não devem descuidar dela. Os diretores admitem fazer algumas concessões pontuais aos desejos dos leitores por matérias mais próximas de seu dia-a-dia, desde que não desviem os jornais daquilo que eles identificam como sua missão, que é o que lhe dá relevância e, no longo prazo, um robusto desempenho econômico.

\section{Inovação tecnológica}

A inovação tecnológica diz respeito aos jornais de muitas maneiras. Uma delas é a sua possível convergência com outros meios. Todos os grandes jornais têm suas versões online, mas isso não mudou substancialmente a confecção do produto: a versão impressa tem sido apenas transposta para a internet, para poder ser lida nela. Esse é o estágio da divergência, em que a informação gerada por um mesmo grupo se distribui por um número maior de meios. A convergência seria algo distinto: a criação de um novo meio, que não seria nem jornal, nem a atual televisão, nem o rádio, nem os atuais jornais online, mas uma fusão dinâmica de todos os seus recursos. Algo assim não é vislumbrado pelos diretores de redação, no curto e nem talvez médio prazo. ${ }^{54}$

$O$ fato de as empresas que editam jornais também manterem operações de internet tem duas implicações. A primeira é que a informação apurada por uma das unidades do grupo pode interessar às outras unidades. Seria desejável compartilhar essa informação no interior do grupo? Como fazê-lo? Além disso,

\footnotetext{
${ }^{54}$ Cf. a distinção entre multimídia convergente e divergente, feita por DEUZE, 2003, p. 184.
} 
a tecnologia permite que um mesmo jornalista produza material para várias palataformas - texto, áudio, imagem. Algumas empresas munem os seus profissionais de vários equipamentos e os incumbem de produzir uma apuração multimídia. ${ }^{55}$ Isso é conveniente para os jornais?

Os jornais são apurados e editados, hoje, partindo-se da premissa de que a internet terá, no decorrer do dia anterior, bombardeado uma parte significativa do seu público-alvo com as notícias que, por isso, deverão receber um tratamento diferenciado. Esse aspecto foi discutido no item anterior, quando falamos da concorrência dos outros meios. Aqui, ele voltará a ser tocado, do ângulo do fazer jornalístico.

Rodolfo Fernandes observa que, ao longo do dia, os próprios profissionais que estão lidando com uma determinada notícia são bombardeados de informações sobre o tema, por meio da internet. "O noticiário é quase uma suíte", define o diretor de redação do Globo. No jargão, a suíte é a matéria que dá seqüência a uma outra, publicada anteriormente, sobre o mesmo tema. A imagem é interessante, porque sugere um diálogo entre o noticiário de internet e o material publicado nos jornais. Em alguma medida, os jornais estão sendo feitos sobre o pressuposto de que o leitor já está informado sobre o fato que o jornal volta a noticiar, acrescentando-lhe o contexto e os outros valores que o jornal é capaz de agregar.

Se isso ocorre com o jornal, que tem uma periodicidade diária, o que dizer das revistas semanais? Elas já estão, desde sempre, condicionadas a esse "diálogo" com os próprios jornais, que noticiam diariamente os fatos que elas "arredondam" (outro jargão), contextualizando e acrescentando novos ingredientes, no fim de semana. As revistas semanais também têm os seus sites na internet e têm adotado a prática de publicar neles informações apuradas que, a seu ver, não podem esperar a próxima edição. Exemplo disso ocorreu em setembro de 2005, quando Veja obteve um documento que comprovava uma reportagem sua publicada no fim de semana anterior, envolvendo o então presidente da Câmara, Severino Cavalcanti, num caso de corrupção. A revista publicou o documento no seu site, no meio da semana. "O

\footnotetext{
${ }^{55}$ Esses repórteres multimídia foram apelidados, um pouco pejorativamente, nos Estados Unidos, de "jornalistas de mochila". Ver STONE, 2002.
} 
jornalismo online já incluenciou e já mudou o jornalismo impresso", concluiu Rodolfo Fernandes, ao citar esse exemplo.

Alguns meses mais tarde, ocorreu um exemplo ainda mais eloqüente, envolvendo os jornais. Em setembro de 2006, no calor da campanha eleitoral, um policial federal entregou ao repórter investigativo Fausto Macedo, do Estado, fotos das pilhas de dinheiro com as quais representantes do PT pretendiam comprar um dossiê sobre políticos tucanos. Os representantes do PT haviam sido flagrados no meio da transação, mas a Polícia Federal se recusava a divulgar as fotos, como costuma fazer. As fotos saíram publicadas no portal do Grupo Estado, na tarde em que foram entregues pelo policial federal. O PT tentou, sem sucesso, obter na Justiça a proibição da divulgação das fotos. $\mathrm{Na}$ manhã seguinte, os jornais deram destaque à tentativa de censura por parte do PT - uma autêntica suíte de um material publicado na internet, como resultado do próprio trabalho de apuração dos jornais.

Num exemplo da tendência inexorável de interação entre os suportes de papel e digital de um jornal, The Wall Street Journal, o maior jornal de economia e negócios do mundo, lançou, em 2 de janeiro de 2007, um novo padrão gráfico, destinado a explorar melhor essa interação. A edição de papel passou a dialogar mais explicitamente com a edição online do jornal, uma fazendo referência à outra. $O$ interessante disso é que, ao mesmo tempo em que a edição de papel passou a valorizar mais o serviço online, também passou a ser mais valorizada em seus atributos específicos. $O$ jornal ganhou em análise e em profundidade de cobertura. As mudanças levaram em consideração a forma como os consumidores de informação se comportam hoje em dia, observou 0 diretor responsável do jornal, L. Gordon Crovitz, em uma carta aos leitores:

Essas inovações têm por objetivo firmar o Journal como o primeiro jornal repensado para o modo como os leitores cada vez mais obtêm suas notícias, freqüentemente em tempo real, de muitas fontes, o dia inteiro. A seção 'Guia dos Leitores' detalha o jornal de amanhã, que começa hoje. O que não mudou é a tradição central do Journal: nosso compromisso de entregar o jornalismo da maior qualidade. Isso significa reportagem com autoridade, precisa e justa, assim como proporcionar análise exclusiva, contexto e perspectiva [...]. ${ }^{56}$

\footnotetext{
${ }^{56}$ Publisher's Letter, publicada em 2/1/2007, disponível no endereço: http://www.dowjones.com/Pressroom/Presskits/NewJournal/NJ PubLetter 3.htm, acessado em 2/1/2007.
} 
O jornal procurou um equilibrio entre o "aconteceu ontem" e a análise e contextualização da notícia:

Seu Journal impresso agora focará ainda mais em 'o que a notícia significa', para além do que simplesmente aconteceu ontem. Embora os repórteres do Journal foquem no jornalismo que olha para a frente [forward-looking journalism], acrescentamos novas matérias que garantem que você não perca nada de importância do dia anterior.

A carta não deixa dúvidas, no entanto, quanto a onde procurar a informação de momento:

The Wall Street Journal Online é o lugar para buscar a notícia sobre 'o que está acontecendo neste instante' na web, através de aparelhos móveis e vídeo e áudio online.

Os princípios, acrescentam os editores do Journal, continuam os mesmos. E os novos meios, assim como o velho e bom jornalismo, são ferramentas a serviço de demandas cada vez maiores por transparência e prestação de contas:

Seja qual for a aparência e a sensação [the look and feel do meio no qual você lê, sabemos que o que mais importa é o jornalismo. O ano que passou foi notável sob qualquer parâmetro. É um tempo de mudança - não só para a mídia, mas também para os negócios em geral e para outras instituiçõeschave, como os governos. À medida que a informação flui mais livremente, atividades antes ocultas se tornam manchetes, com a prestação de contas [accountability] corretamente enfatizada.

The Wall Street Journal, fundado em 1889 por Charles Dow e Edward Jones, é o principal título da Dow Jones \& Company, um dos maiores grupos de mídia do mundo. A circulação somada de suas edições impressa e online é de cerca de 2,1 milhões. Na redação da edição impressa trabalham mais de 600 jornalistas. Eles fazem parte de um total de 1.900 profissionais do grupo Dow Jones, que vende informações sobre economia e negócios e edita The Wall Street Journal Asia, The Wall Street Journal Europe e The Wall Street Journal Online (www.wsj.com), o jornal com maior carteira de assinantes da internet. ${ }^{57}$

No Globo, as operações do jornal e do portal na internet já eram conjuntas, na época da entrevista com os diretores de redação. Faltava a união física das redações no mesmo andar, que dependia de uma obra de engenharia. "O repórter já sabe que, quando sai de uma entrevista, o mais rapidamente possível, deve botar isso no online", disse Rodolfo. O mesmo acontece na

\footnotetext{
${ }^{57}$ Dados do press release Redesigned Wall Street Journal hits newsstands today, de 2/1/2007, disponível no endereço http://www.dowjones.com/Pressroom/PressReleases/Other/US/2007/0102 US TheWallStreetJ ournal 8660.htm, acessado em 2/1/2007.
} 
Folha e no Estado. Além disso, vários profissionais dos três jornais mantêm blogs nos respectivos portais.

Já a relação do jornal $O$ Globo com a TV Globo é bastante diferente. Rodolfo Fernandes diz que não vê "como a televisão vá abrigar uma matéria feita por repórter (de jornal)". Ele acha que o jornal só tende a se distanciar da TV, à medida em que ele é "cada vez mais um espaço de contextualização da notícia, de opinião": "A missão para a qual eles estão direcionados está cada vez mais distante." Colunistas do Globo trabalham também como comentaristas da TV Globo e da rádio CBN, pertencente ao grupo, mas são tarefas separadas, e em geral de análise, e não o tipo de apuração e produção simultâneas que caracteriza o repórter multimídia. Segundo Rodolfo Fernandes, não há sequer aproveitamento da informação apurada pelo jornal e pela TV:

Eu diria que a nossa sinergia com a TV Globo é zero. Talvez exista até uma certa competição velada. Até porque, são produções diferentes. Não tem condição de você acompanhar uma produção de televisão e fazer a mesma coisa num jornal. [...] São direções totalmente separadas. A gente não sabe 0 que eles estão fazendo, e vice-versa.

Quando concedeu a entrevista, em novembro de 2005, Sandro Vaia preparava a criação de um "mesão", no qual as chefias do Estado, do portal e da Agência Estado compartilhariam informações ao longo do dia. O "mesão" foi implementado em setembro de 2006, um mês antes da sua saída da empresa, e foi mantido sob a nova direção de Ricardo Gandour. Segundo Sandro Vaia, o jornal, o portal e a agência deviam ficar "fisicamente juntos", para "respirar o mesmo ar [...] e vibrar na mesma intensidade, tanto a redação de papel, em tempo diferido, como a em tempo real."

O então diretor do Estado assegurou que não se tratava de os profissionais fazerem trabalho dobrado, de "despedir 30 e fazer os outros 30 fazerem o trabalho daqueles que foram embora", como aconteceu em vários outros processos de integração; mas, sim, de fazer todos "pensarem com a mesma cabeça".

Sandro Vaia rejeitou, porém, as práticas, adotadas por alguns meios online, de coordenar as atividades editorias com as comerciais. "É Igreja e Estado mesmo", disse ele, referindo-se ao jargão cunhado pela revista Time, que 
define a independência da redação em relação à área comercial. Graças ao hipertexto, alguns sites criam links entre o conteúdo informativo e anúncios publicitários ou promoções de marketing. Esse tipo de casamento é um tabu para o jornalismo considerado de qualidade.

Otavio Frias Filho se mostrou um pouco cético quanto à sinergia, que ele definiu como um eufemismo para o corte de custos. Mas informou que, na Folha, também se estava discutindo a "fusão" de operações das redações do jornal e do portal do grupo, o UOL, um dos mais acessados no Brasil: "Estamos discutindo isso também, avaliando os prós e contras. Pessoalmente, estou com a sensação de que essa tendência de fusão talvez seja inarredável."

Alguns sites na internet têm colocado à disposição de seus leitores ferramentas para eles participarem da hierarquização da informação. Por meio de softwares de ratings, a audiência vota nas matérias mais importantes, que são colocadas em maior destaque. Segundo especialistas como Ramón Salaverría ${ }^{58}$, essa e outras experiências de interatividade na internet parecem apontar para uma nova relação emissor-receptor, ou para o fim dela.

Os diretores de redação não se mostraram muito sensibilizados com essas potencialidades da interatividade, pelo menos não para o meio jornal. Otavio Frias Filho acredita que a interação seja uma tendência, mas não majoritária: "Isso exige tempo, numa época em que o tempo é muito escasso e muito disputado." Os diretores de redação preferem salientar o inverso - o valor do trabalho jornalístico de ordenar e de hierarquizar a informação. No ambiente predominantemente caótico e desordenado da internet, em que a informação se encontra fragmentada, descontextualizada, e sem uma ordem de importância, o trabalho de edição, que caracteriza os jornais, ganharia importância, em vez de perdê-la. Diz Otavio Frias Filho:

Quando estou lendo o New York Times, para usar o exemplo clássico, não estou só me informando e louvando os textos, as matérias do NYT, mas estou também encontrando o aporte expresso na maneira pela qual aquele grupo de profissionais organizou ou selecionou, editou fatos relevantes nas últimas 24 horas. Então, tenho a impressão de que um dos objetivos do jornalismo de qualidade nesse cenário competitivo em que a gente está vivendo é o fato de que o estilo, a maneira de encarar os fatos e de editá-los também é um ativo, é algo que tem valor.

\footnotetext{
${ }^{58}$ Ver no próximo capítulo.
} 
Como se vê, o advento da internet e dos serviços de notícias online mudaram a rotina da redação. $O$ processo de apuração para o jornal de papel ganhou um novo dinamismo, com a possibilidade de o resultado dessa apuração ser publicado antes do próprio jornal, gerando um fato, que por sua vez o jornal repecutirá em sua edição. A apuração para os jornais impresso e digital está integrada. A coordenação de reportagem e de edição encontra-se em distintas fases de integração, em cada jornal. Mas, em todos eles, está em perspectiva. Entretanto, os jornais se mantêm distantes das inovações que alteram as relações entre emissor e receptor, e que subvertem a ordem vertical da edição. Para os jornais, o universo de informação em rede e horizontal criado por essas inovações serve de contraponto ao produto oferecido pelos jornais, realçando o valor agregado do trabalho de edição. Noutras palavras, é algo para o jornal se contrapor, e não para assimilar.

A seguir, cotejaremos essas visões com a análise de dois especialistas - um americano e um europeu. 


\section{CAPÍTULO 4 - A VISÃO DE ESPECIALISTAS}

Ramón Salaverría, diretor do Laboratório de Comunicação Multimídia da Faculdade de Comunicação da Universidade de Navarra, em Pamplona (Espanha), é um pesquisador de campo dos meios digitais. Editou a coletânia de papers Towards new media paradigms: contents, producers, organisations and audiences (2004) e coordenou o Manual de redacción ciberperiodística (2003). Salaverría concedeu entrevista ao autor em dezembro de 2004, em São Paulo.

Nicholas Negroponte, co-fundador do Media Laboratory do Massachusetts Institute of Technology (MIT), em Boston (EUA), tem trabalhado nos últimos anos, também em campo, com as potencialidades da tecnologia e dos meios digitais na disseminação do conhecimento. É autor do clássico Vida digital (1995). Concedeu a entrevista em julho de 2005, em Brasília.

Apesar dos enfoques de pesquisa diferentes, Salaverría e Negroponte expuseram idéias bastante coincidentes em relação à concorrência dos novos meios, à mudança dos hábitos de leitura e à inovação tecnológica. Para eles, a absorção do jornal pelo suporte digital é algo muito mais premente do que para os diretores de redação dos três grandes jornais brasileiros. A visão dos especialistas coincide com a dos diretores, no entanto, em relação à relevância ainda maior do jornalismo nesse ambiente da informação em rede.

A entrevista com Negroponte ocorreu dias depois de o New York Times anunciar que o seu número de leitores na internet havia superado o de leitores no jornal físico. O especialista previu que os jornais de papel seriam amplamente "descontinuados" em menos de dez anos. Negroponte fez uma analogia com as câmeras fotográficas de filmes, que deram lugar às digitais num espaço de tempo muito mais curto do que se poderia imaginar. Segundo ele, o jornal não será mais impresso, mas lido na tela.

Entretanto, diz ele, a tela também deve mudar. Em vez dos monitores luminosos, que muitos usuários consideram incômodos para leituras mais longas, os jornais deverão ser lidos numa tela reflexiva, que não emite luz, como a do e-link, desenvolvido pelo Media Lab do MIT. São telas que absorvem luz, flexíveis e finas, podendo ser dobradas e levadas para qualquer 
lugar. "Poderá se parecer com papel e se sentir como se fosse papel. Mas é um pedaço de plástico que é um computador", descreveu Negroponte.

Tanto Negroponte quanto Salaverría, no entanto, dizem que o suporte não deve preocupar o setor, cujo negócio é a informação, não o papel. "O que está morto é o papel, não a notícia", disse Negroponte. "O fato de que ainda se faça em papel é meio intrigante, mas será descontinuado rapidamente. $O$ jornalismo não vai desaparecer. O jornalismo vai aumentar."

O especialista observa que estão surgindo formas diferentes de jornalismo, como os blogs. Mas que também se continuará fazendo o jornalismo convencional. "Os dois tipos conviverão - o de baixo para cima e o de cima para baixo." Como exemplo, ele cita o guia de restaurantes Zagat (www.zagat.com), feito pelos freqüentadores, que votam nos restaurantes. Esse tipo de publicação convive lado a lado com os guias escritos pelos especialistas. Cada um terá o seu espaço, avalia Negroponte.

Na mesma direção, Salaverría destaca a experiência de fóruns e sistemas de informação na internet que permitem à audiência participar da interpretação, da seleção e da hierarquização da informação, de forma "democrática". Ele cita os exemplos dos sites Slash Dot (www.slashdot.org) e Barra Punto (www.barrapunto.com). Com isso, o leitor combina os papéis de usuário e de emissor de informação. Como há leitores altamente informados sobre determinadas áreas, argumenta Salaverría, essa pode ser também uma fonte de informação de alta qualidade. "Essa é a grande novidade", diz o especialista.

Ambos acreditam que, nesse cenário, a importância do jornalismo vai crescer, e não diminuir. Os meios de comunicação continuarão com sua missão de "interpretação, hierarquização e seleção da informação", que seguirá sendo relevante, diz Salaverría. Para Negroponte, esse "jornalismo de cima para baixo encontrará crescentemente o seu valor no ponto de vista". Com exceção de alguns poucos fatos, diz ele, "a maioria das matérias em um jornal é importante por causa do ponto de vista sobre o fato, não por causa do evento em si, quantas pessoas estiveram envolvidas, quantas pessoas morreram ou citações precisas." 
De acordo com Salaverría, o que importa, para os jornais, é a demanda por informação. E o problema vital do desinteresse dos jovens pelos jornais não implica um desinteresse pela informação, mas pelo tipo de jornal que se está fazendo. Na Espanha, diz o pesquisador, há um tipo de jovem "interessado em aspectos lúdicos, no ócio, mas que também tem interesses especializados, como a tecnologia, a música, aspectos que talvez não sejam a informação em geral, mas em torno dos quais se estão desenvolvendo cadeias de informação muito especializadas". Isso, diz Salaverría, "está criando um hábito de consumo de informação".

"Queremos pensar que, na medida em que esses jovens vão adquirindo certa maturidade, esses hábitos de informação não vão se limitar unicamente ao lúdico, mas abrangerão temas que afetam nossa sociedade", disse Salaverría, exprimindo uma visão compartilhada por Otavio Frias Filho e Rodolfo Fernandes, no capítulo anterior.

Salaverría reconhece a falta de entusiasmo dos editores com as potencialidades da interatividade:

Há uma dificuldade por parte dos meios de comunicação e dos jornalistas em particular em se acomodar a um novo entorno no qual as audiências têm a possibilidade não só de responder, mas de falar entre si a propósito do que nós Ihe informamos. Isso gera processos de movimento informativo que até agora não existiam ou que pelo menos não se tornavam públicos. $A$ forma de modernizar os meios de comunicação virá em boa medida condicionada pelo modo de interpretar a interatividade.

$\mathrm{Na}$ opinião do especialista, a hipertextualidade e a "multimidialidade" já estavam presentes, de alguma forma, nos meios tradicionais. Ele considera que as matérias auxiliares ("retrancas", no jargão), fotos e gráficos se vinculam à matéria principal como se fossem recursos de hipertexto. Igualmente, diz ele, a televisão já é uma plataforma multimídia. A verdadeira novidade, acredita, está nos recursos interativos:

A interatividade, ou seja, incorporar o leitor ao discurso jornalístico, é algo radicalmente novo, e é a isso que os meios digitais estão conferindo um protagonismo. De certa maneira, esse impacto já está chegando aos meios impressos, ao rádio e à televisão. Os impressos já empregam sondagens com os leitores, abrem a possibilidade de os leitores proporem temas para debates, enfim, estamos assistindo aos primeiros passos, mas terminará mudando o discurso jornalístico que conhecemos há séculos. 
Salaverría reconhece a incapacidade geral dos veículos online de investir na produção de conteúdo de qualidade, apontada pelos diretores de redação. Para ele, depois da explosão da bolha da internet, no ano 2000, quando as ações, altamente inflacionadas, das companhias "ponto-com" despencaram na bolsa Nasdaq, os investimentos no setor minguaram. Os anúncios publicitários, também. Os investidores agora esperam que os meios digitais apresentem rentabilidade para aportarem mais capital neles. Mas os meios não são rentáveis justamente pela falta de aporte de recursos, observa Salaverría, gerando um círculo vicioso. Segundo ele, na Espanha, só havia, em 2004, um jornal rentável na internet: a edição digital de El Mundo. Era também o que tinha mais jornalistas, acrescentou ele, sugerindo a vinculação entre investimento, qualidade e rentabilidade.

Quanto à convergência dos meios, Salaverría aponta dois movimentos: um "centrípeto" e outro "centrífugo":

Centrípeto no sentido de que alguns elementos acumulam possibilidades tecnológicas que antes só eram possíveis em distintas ferramentas tecnológicas individuais. Agora, com uma única ferramenta, podem-se fazer muitas coisas. O computador, nesse sentido, está-se convertendo no núcleo estratégico de todos esses eletrodomésticos que funcionam na casa. Mas, por outro lado, há um modelo centrífugo, que faz com que todas as ferramentas, como os telefones celulares, acumulem também possibilidades que antes eram patrimônio do computador; os televisores acumulem possibilidades que antes eram patrimônio do rádio e assim por diante. Há um processo de intercâmbio, no qual, com qualquer ferramenta tecnológica, podemos fazer muito mais coisas do que antes.

Salaverría mostra que parte da dificuldade de se compreender as potencialidades da internet está na maneira como a conhecemos até aqui:

Nesta primeira década, a web esteve condicionada por uma limitação física: era preciso estar conectado a um computador para poder acessar a rede. Isso já não será mais assim. Agora, a internet vai se converter em um tipo de rede ambiental, que vai estar à nossa disposição através dos celulares. [...] Com a terceira geração da telefonia - um sistema no qual teremos não só voz e dados, mas conteúdo audiovisual em banda larga -, isso vai resultar numa revolução lingüística, porque poderemos acessar a informação de maneira direta, a todo momento. A informação de última hora nos vai chegar pelos celulares."

Como os jornais devem interagir nesse ambiente de vertiginosa expansão dos modos de aquisição e distribuição da informação é obviamente uma questão em aberto. A visão dos especialistas aponta para uma assimilação do jornal de papel pela plataforma digital muito mais rápida e incondicional do que os 
diretores de redação estão dispostos a admitir. Diante da descrição, digamos, desprendida do cenário no prazo médio, feita pelos dois especialistas, as posições dos diretores de redação parecem predominantemente defensivas.

Os três estão submersos no negócio jornal, e sua missão principal, neste momento de acirramento da concorrência e de queda da leitura, parece ser a valorização dos atributos que diferenciam os jornais dos outros meios. Nesse esforço, os jornais aparecem distantes do ambiente descrito pelos especialistas. Mas, se as câmeras digitais servirem de referência, é possível que as transformações venham mais rápido do que a maioria de nós espera.

Se aceitarmos o pressuposto de que a assimilação do jornal pelo ambiente digital é um fato consumado, e de médio prazo, que tipo de conseqüências isso tem para a estratégia dos jornais de se diferenciar por meio de seus atributos tradicionais? Ou devemos continuar chamando de jornal o veículo com suporte sobre papel? Se a analogia com as câmeras fotográficas estiver correta, o jornal sobre papel se tornará um produto residual e ultrapassado, de "segunda classe", como as câmeras de filmes. O centro dinâmico da produção de jornalismo nesse meio se deslocará do papel para o digital.

É perfeitamente possível visualizar o jornal, tal como é feito hoje, transposto do suporte de papel para o digital. Não é preciso imaginação. Essa é a realidade da versão digital dos grandes jornais, não só no Brasil, mas no mundo todo. No seu deslocamento para o universo online, os jornais levam consigo os seus valores agregados, entre eles a hierarquização da notícia. Como combinar esse atributo com as novas demandas da interatividade, descritas por Salaverría e Negroponte como traços essenciais dos meios digitais?

$\mathrm{Na}$ medida em que rejeitem a interferência do leitor na sua tarefa precípua de seleção e hierarquização - considerada o núcleo da atividade jornalística -, que espaço ficará reservado para os jornais no ambiente digital? Na analogia de Negroponte, sobre os guias de gastronomia, pode haver um convívio entre as duas formas de ordenação da informação: a que é feita pelo receptoremissor (uma polarização que, no limite, desaparece) e que é objeto da edição jornalística.

O espaço ocupado por cada um no futuro é, obviamente, uma incógnita. 


\section{CONCLUSÃO}

Quando o projeto deste trabalho foi esboçado, no fim de 2003 , os jornais estavam imersos numa crise. Sua circulação vinha caindo desde o início da década, e seguiria caindo, por mais um ano. Refeita da explosão da "bolha", em 2000, a internet se consolidava, sobre parâmetros econômicos mais realistas, como um meio de informação que atraía mais e mais audiência e receita publicitária.

Dois anos depois, no fim de 2005, quando os diretores de redação do Estado, da Folha e do Globo concederam suas entrevistas para este estudo, celebravam o aumento da circulação dos jornais e marcas inéditas de lucratividade.

A reversão de expectativas serviu de vacina para este trabalho. Este é um campo no qual conclusões precipitadas não são aconselháveis. A crise dos jornais não é o tema deste trabalho. A tentativa, aqui, foi a de identificar o que há de estrutural, para além do crítico.

A tentação de extrapolar de um para o outro é grande. Períodos de mudanças vertiginosas, como o que vivemos, convidam a polarizações, a conclusões categóricas. Há a decretação da morte do jornal. E há o seu oposto: a convicção de sua eternidade. A verdade provavelmente reside em algum ponto, entre os dois extremos.

Por isso, menos do que uma conclusão - um fim talvez ambicioso demais para o caso -, trata-se mais aqui de uma mediação. Uma mediação entre profecias extremas; entre leitores, jornalistas e publicitários; entre pesquisadores, gurus e diretores de redação.

Os três fatos estruturais identificados por este trabalho, em torno dos quais ele gravitou do início ao fim, são: o acirramento da concorrência, a mudança nos hábitos de leitura e a inovação tecnológica. Os dois primeiros estão presentes na redução estrutural da fatia ocupada pelo jornal no mercado da informação. O terceiro representa os desafios que o jornal tem pela frente, as múltiplas possibilidades de resposta a essas mudanças estruturais.

Os picos de circulação observados na segunda metade dos anos 90 não servem de referência para avaliar, no nível estrutural, o comportamento do 
setor na primeira metade desta década. Os parâmetros do negócio mudaram. Aquele aumento de circulação foi "alavancado", se quisermos usar um jargão da economia, pelo aumento do poder aquisitivo, crescimento da receita e redução dos gastos correntes em dólar, decorrentes da estabilização e valorização do real. Naquele período, os jornais não estavam vendendo apenas notícias, colunas, artigos, fotografias, infográficos, informações de serviços e classificados, mas, também, coleções de livros, de filmes e de CDs. Portanto, aqueles padrões de circulação não eram estruturais, mas críticos.

Sendo assim, a primeira metade desta década deve ser vista em si mesma. Os dados quantitativos revelam que o número de exemplares de jornal por habitantes adultos está diminuindo aceleradamente. A queda foi de $29 \%$, no período de 2001 a 2005. Esse dado é consistente com a diminuição do tempo dedicado à leitura dos jornais. E com a substituição de sua leitura pelo uso da internet como fonte de notícias e informações gerais, relatada por $41 \%$ dos usuários da rede.

$\mathrm{Na}$ pesquisa qualitativa, verificamos como o jornal se vê obrigado a reacomodar-se no interior de uma cesta de meios de informação. O número de meios cresceu, e o tamanho da cesta - que seriam o tempo e o dinheiro disponíveis para consumo de informação - ou permaneceu o mesmo ou diminuiu, com o trabalho, o trânsito e os afazeres cotidianos competindo pela atenção do público-alvo.

Não que não haja interesse pela informação - e esse é um ponto fundamental. A informação é reconhecida como um produto vital. Mas, em vez de o público ter de buscá-la, ele é "bombardeado" - um termo freqüentemente usado pelos participantes da pesquisa qualitativa - por ela, e chega a ressentir-se de certa saturação.

A informação de tipo "utilitário" - sobre o local onde os usuários vivem e trabalham, sobre o trânsito, lazer e consumo, entre outros - ganha em importância. Nesse tipo de produto, jornais locais, sites na internet, emissoras de rádio e até alguns canas de TV a cabo são, em geral, mais eficazes do que jornais de circulação nacional. Com uma ressalva: jornais maiores dispõem de recursos mais condizentes com os gastos e investimentos necessários para a 
reportagem sobre os temas locais. O que relativiza o verdadeiro poder de fogo dos jornais menores para atender às demandas de seu público.

Por outro lado, a demanda por informação mais completa, pela contextualização das notícias, pela análise e interpretação dos fatos não se perdeu. Ao contrário, aquele "bombardeio" de informações parece exigir, para o público-alvo dos jornais, um produto que the dê sentido, como o fazem as revistas e os jornais.

Nesse quadro, é difícil prever se, no curto prazo, a demanda pelos grandes jornais diminuirá, continuará estável ou aumentará. No médio e longo prazos, a tendência parece ser a de queda dessa demanda. Isso porque as mudanças geracionais não favorecem os jornais. É provável que, ao envelhecer, uma parcela dos jovens adquira gosto pelos jornais. Mas é também razoável esperar que uma outra parcela, talvez majoritária, não o faça. A redução dos índices de leitura e do número de exemplares por cidadãos adultos aponta claramente nessa direção.

Por que grau de transformação os jornais passarão, em sua resposta ao acirramento da concorrência, sobretudo pelos meios digitais, e às mudanças do hábito de leitura? Em que eles se transformarão? Quanto da inovação tecnológica eles assimilarão? E quais as conseqüências disso?

Modificar o jornal em função das tendências observadas não seria uma tarefa fácil. Ele correria o risco de perder o que tem e de não ganhar o que lhe faz falta.

Vimos que o público potencial dos jornais - pessoas das classes A e B+ habituadas a consumir regularmente informação, seja por que meio for reconhece neles atributos cujo valor não é trivial. Dentre todos os meios, o jornal é descrito como "o mais completo" e o de "maior credibilidade", o que "vai fundo", pelos participantes da pesquisa focus group relatada no Capítulo 1.

O jornal dá sentido à informação de uma maneira que a maioria dos outros meios - a exceção é a revista semanal - não dá. E isso é considerado importante, sobre o pano de fundo do bombardeio cotidiano de informações fragmentadas. 
Em alguma medida, o jornal parece ocupar uma posição privilegiada na cesta de opções de meios das quais dispõe o público. O jornal não é quente demais, como o rádio, a televisão e a internet, identificados como superficiais e fragmentários. Também não é frio demais, como as revistas, que muitos se queixam de darem voltas demais antes de chegar ao ponto, ao " $x$ " da questão. Ele é objetivo sem ser raso e reflexivo sem ser evasivo.

Os grandes jornais têm usufruído de um bom equilíbrio entre receitas e gastos correntes e investimentos. Suas redações são grandes. Sua estrutura logística é adequada. De todos os meios, os grandes jornais são, de longe, os que mais produzem conteúdo jornalístico - notícias e análises próprio.

Até mesmo o suporte de papel, que às vezes parece condenado, merece elogios, pela portabilidade e independência de aparelhos e conexões.

Os anunciantes também identificam no jornal qualidades que Ihes são caras. Seu público tem alto poder aquisitivo; os anúncios publicados neles emprestam o seu prestígio para as marcas dos anunciantes. Até características que poderiam ser consideradas como limitações têm o seu lado positivo, como a circunscrição geográfica bem definida pela sua distribuição física, que permite ao anunciante estabelecer uma clara estratégia espacial. E os jornais têm um conhecimento relativamente bom do perfil de seu público.

É o reconhecimento de todos esses atributos que leva os diretores dos jornais a acreditarem que a melhor resposta ao acirramento da concorrência seja 0 investimento nas qualidades que os diferenciam dos outros meios. A reação dos jornais ao crescimento da internet parece oposta à que teve o USA Today com relação à televisão, duas décadas atrás. O jornal americano tentou assimilar as qualidades da televisão, com profusão de fotos coloridas e textos telegráficos.

Se quiséssemos sintetizar a estratégia do USA Today em duas frases, elas seriam: Ser jornal é ruim e ser TV é bom. Precisamos fazer de conta que somos TV. Em contrapartida, o que os grandes jornais brasileiros estão dizendo é: Ser jornal é bom, desde que sejamos, de fato, bons jornais.

Aquilo que o jornal pode fazer melhor são histórias bem contadas, com contextualização, interpretação, análise e opinião. Mas ele está longe de ter 
atingido o ponto ótimo nessas tarefas. Na verdade, o jornal ainda está muito mais estruturado para contar "o que" do que para explicar "por quê".

As redações são compostas de centenas de profissionais, cujo alcance técnico e cuja rotina são adequadas para a produção de notícias, não para agregarIhes outros valores.

$\mathrm{Na}$ visão dos diretores de redação, os jornais não podem, no prazo visível, abandonar a notícia. Terão de continuar nessa posição híbrida, de escrever para um público que já tem a informação básica do que se passou na véspera e para outro que esperou o jornal para receber a notícia.

Sendo assim, o caso aqui não é de trocar, mas de acrescentar. Os jornais precisam de mais jornalistas, e não são quaisquer jornalistas. São os que têm talento, preparo, experiência e condição de trabalho para oferecer ao leitor textos intelectualmente sofisticados, que tratam a notícia de forma multidimensional, com suas implicações humanas, sociais, políticas, econômicas e históricas. Esse serviço custa caro.

Quais as chances de os três grandes jornais brasileiros trilharem esse caminho de maneira sustentável?

Vimos que essa é a intenção dos diretores de redação dos três jornais - e que possivelmente essa intenção se conservará no Estado, mesmo com a saída de Sandro Vaia, já que o Conselho de Administração informou que as diretrizes empresariais e editoriais seriam mantidas.

O primeiro passo dos diretores de redação é convencer as outras áreas das empresas que editam os respectivos jornais da conveniência dos gastos correntes e investimentos que essa estratégia implicaria.

Vimos que, em contextos variados, é possível estabelecer uma relação causal entre qualidade, influência e credibilidade, de um lado, e circulação, penetração e rentabilidade, de outro.

Quando da entrevista com os diretores de redação, em rovembro de 2005, Sandro Vaia informou que o Estado se preparava para fazer uma importante inflexão em sua estratégia comercial: ampliar a sua circulação nacional. Com base num cálculo meramente contábil, o Estado restringira, por décadas, a sua 
circulação fora de São Paulo, Brasília e Rio a um patamar mínimo. Enquanto isso, a Folha e o Globo seguiram investindo em sua presença nacional. Essa decisão custou influência e prestígio ao Estado, e estava sendo revista.

Esse é um exemplo de reconhecimento da correlação entre valores intangíveis e rentabilidade, num jornal. Há muitos outros: a publicação dos cadernos culturais, que em muitos casos não dão retorno publicitário; a manutenção de correspondentes no exterior; a realização de coberturas dispendiosas, como a da Copa do Mundo e a de guerras.

Portanto, há um terreno propício para essa negociação entre a redação e as outras áreas. Até porque esse é obviamente um processo gradual, tanto nos investimentos quanto nos resultados.

A próxima pergunta seria: terá o resultado almejado?

Para respondê-la, é preciso considerar as outras mudanças que o jornal estará atravessando, ao mesmo tempo em que se lança para esse eventual salto de qualidade.

O número de pessoas que lêem os jornais online está aumentando dia após dia. No New York Times, ele já superou o número dos que lêem o jornal em papel. A internet tem uma penetração extraordinariamente dinâmica no Brasil. Como vimos, no período de quatro anos entre o início de 2002 e o fim de 2005, a internet ganhou 5,1 milhões de novos usuários, atingindo a marca de 33,4 milhões. Desses, mais da metade $(57,6 \%)$ buscam notícias e informação na rede - os produtos que compõem o core business do jornal.

Logo, há fortes razões para acreditar que, também no Brasil, a leitura dos jornais online ganhará importância crescente. Ora, nos três grandes jornais brasileiros, os gastos correntes de impressão e distribuição representam entre $30 \%$ e $40 \%$ do total. Se uma parte da tiragem dos jornais migrar do produto físico para o produto online, isso representará uma economia.

Há, contudo, um movimento no sentido contrário: a internet está "roubando" verbas publicitárias dos jornais. A publicidade representa, grosso modo, 75\% das receitas dos grandes jornais ( $50 \%$ em anúncios e $25 \%$ em classificados). 
Qual será o balanço dessa equação? Os jornais - entendidos como a soma das duas operações, em papel e online - sairão dessa transição com mais dinheiro para os gastos correntes e os investimentos? Não há elementos para responder a essa pergunta.

Mas, se aceitarmos que uma migração, parcial ou total, do suporte de papel para o online ocorrerá, incentivada pela economia que ela representa para os jornais, então é preciso contar com outras mudanças possíveis. Os meios online têm formas diferentes de lidar com seu público e também de vender espaços publicitários.

A afirmação segundo a qual a mudança de suporte de papel para digital não tem importância para o jornal e para o jornalismo é retórica. É óbvio que o suporte influi na linguagem, na forma de fazer jornalismo. Não precisamos nos deter aqui em comparações entre o rádio e a TV, entre o jornal e o rádio, entre o jornal e a TV, entre cada um deles e os meios online.

Usuários de internet tendem a esperar que os meios digitais Ihes proporcionem ferramentas para intervir na arquitetura da informação ali disposta. Esse é um recurso ainda em fase de desenvolvimento. Mas tudo indica que se tornará uma demanda crescente por parte dos usuários a capacidade de contribuir com informações e de intervir na sua hierarquização.

Os jornais, provavelmente, resistirão a isso. Sua atual experiência com a internet é, em grande medida, a mera transposição de suas edições de papel para versões online, com pouca ou nenhuma alteração. No caso das versões em $\mathrm{PDF}^{59}$, as páginas dos jornais são publicadas, sem tirar nem pôr, nos sites dos jornais na internet. As versões em $\mathrm{HTML}^{60}$ também não modificam a estrutura das matérias.

Haverá outros meios informativos, no entanto, dispostos a fazer concessões às demandas dos usuários - em analogia, se poderia observar que, da mesma maneira que as revistas reorientaram suas políticas editoriais pelas pesquisas qualitativas com os leitores, e os jornais se recusaram a fazê-lo. Surgindo

\footnotetext{
${ }^{59}$ Portable Document Format, do sistema Adobe, que reproduz documentos na internet conservando suas características na versão sobre papel.

${ }^{60}$ HyperText Markup Language, formato predominante dos textos na internet, que permite criar links para outros endereços na rede.
} 
outros meios que atendam às demandas de interatividade dos usuários de internet, os jornais poderão perder público.

A publicidade na internet tem como valor agregado a capacidade de transformar cada parcela de conteúdo em um link para um anúncio publicitário, uma operação de compra ou de marketing, graças aos recursos do hipertexto.

Essa forma de ganhar dinheiro na internet, simbolizada pela receita publicitária bilionária do Google, deverá buscar espaço também nos jornais online. Em muitos sites de jornais de outros países, como o do New York Times ou o do israelense Haaretz, por exemplo, elementos hipertextuais são agregados às matérias, com algumas palavras-chave transformadas em links para outros conteúdos, sejam informativos ou publicitários. No Brasil, no momento em que este texto é redigido, esses recursos ainda não foram introduzidos nas versões online do Estado, da Folha e do Globo. É provável que venham a ser.

A utilização desses recursos de hipertexto conduz a mudanças nas estratégias de venda de espaço publicitário e nas relações entre as áreas editorial e comercial. Em alguns sites de informação e notícias na internet, existe a figura de um gerente que faz a intermediação entre o planejamento de pauta da redação e as estratégias de venda de publicidade.

Seguindo a tradição da separação "Igreja-Estado", chave para sua credibilidade, os grandes jornais deverão resistir a essa investida. De novo, outros meios informativos aceitarão, como já aceitam, fazer essa ponte entre o editorial e o comercial. Em que medida isso prejudicará a fatia do mercado publicitário e o faturamento dos jornais online e, com ele, a receita global dos jornais?

Paralelamente a essas mudanças, há um processo de transformação na propriedade e gestão dos jornais. No Estado e no Globo, os acionistas, que são os integrantes das famílias de jornalistas às quais os jornais pertencem há várias décadas, recuaram de seus postos de gestão do dia-a-dia e foram substituídos por profissionais contratados. Esse é um passo numa possível transição para a mudança no modelo de propriedade dos jornais, de empresas familiares para companhias de capital aberto. A Editora Abril foi a primeira a aproveitar uma nova legislação que permite a venda de até $30 \%$ de seu capital. 
As demandas por capitalização das empresas jornalísticas, num ambiente de acirramento da competição, aumentarão. E poderão conduzir a novas mudanças na legislação e a novas e mais abrangentes aberturas de capital. Isso ocorreu nos Estados Unidos.

$\mathrm{Na}$ literatura, há visões diferentes sobre as conseqüências, para o jornalismo. Alguns autores - talvez a maioria - afirmam que executivos contratados, às vezes provenientes de outros segmentos, tendem a vergar-se sob as pressões por mais lucratividade no curto prazo, vindas dos acionistas, em detrimento da qualidade dos jornais. As famílias de jornalistas proprietários de jornais, além disso, conferiam-Ihes um respaldo de identidade e de credibilidade.

Outros autores contestam essa visão. Para eles, as famílias proprietárias de jornais não eram menos sequiosas por lucros, nem menos imediatistas em sua relação com o negócio. Com a agravante de que interferiam de forma deletéria na independência editorial dos jornais, em função de seus interesses e convicções pessoais, prejudicando sua credibilidade.

O mais provável é que não se possa extrair uma regra disso. O fato incontornável é que a gestão dos jornais segue 0 caminho da profissionalização, e ela representa uma mudança de cultura. A redação continuará sendo gerida por jornalistas. Mas nas áreas comercial, industrial, de circulação e financeira, profissionais contratados, vindos talvez de outros setores, assumirão cada vez mais responsabilidades.

Mudanças geracionais não afetam apenas o público-alvo. Novas mentalidades e culturas também se instalam entre os gestores. Isso é visível na atual geração de diretores de redação. Eles rejeitam a cultura de um passado recente, anterior à estabilização da moeda no Brasil, em meados da década de 90. Nessa cultura, identificada por Otavio Frias Filho com o "esbanjamento", não havia uma relação consistente entre gastos, investimentos, receitas e rentabilidade. Essa mentalidade se esgotou.

Da mesma maneira, é possível esperar outras mudanças de cultura e de mentalidade na gestão dos jornais. Os valores do jornalismo sobreviverão a essas mudanças? É difícil prever. Mas a resposta, em grande medida, depende 
do êxito dos grandes jornais em atravessar a atual fase de transição preservando a sua relevância e rentabilidade sem abrir mão desses valores. 


\section{REFERÊNCIAS BIBLIOGRÁFICAS}

ALCÂNTARA, Alex Sander. O valor da notícia. Revista Imprensa. № 218, edição de novembro de 2006. Pág. 66.

ASSOCIAÇÃO NACIONAL DE JORNAIS (ANJ). Circulação dos jornais

brasileiros. Disponível no site da ANJ, no endereço:

http://www.anj.org.br/?q=node/177. Acessado em 12/12/2006.

ASSOCIAÇÃO NACIONAL DE JORNAIS (ANJ). Circulação dos jornais no

mundo. Disponível no site da ANJ, no endereço:

http://www.anj.org.br/?q=node/183. Acessado em 12/12/2006.

ASSOCIAÇÃO NACIONAL DE JORNAIS (ANJ). Público leitor de jornais no

Brasil. Disponível no site da ANJ, no endereço:

http://www.anj.org.br/?q=node/179\&PHPSESSID=10dc083445f44b06f7d894f85

fc3d1c5. Acessado em 12/12/2006.

ASSOCIAÇÃO NACIONAL DE JORNAIS (ANJ). Tempo de leitura de jornais no

Brasil. Disponível no site da ANJ, no endereço:

http://www.anj.org.br/?q=node/179. Acessado em 12/12/2006.

ASSOCIAÇÃO NACIONAL DE EDITORES DE REVISTAS (Aner). Evolução da circulação. Disponível no site da Aner, no endereço:

http://www.aner.org.br/conteudo/1/artigo1862-1.asp. Último acesso: 13/12/2006 ASSOCIAÇÃO NACIONAL DE EDITORES DE REVISTAS (Aner). Total de títulos. Disponível no site da Aner, no endereço::

http://www.aner.org.br/conteudo/1/artigo1861-1.asp.último acesso: 13/12/2006

AZEVÊDO, Sandra Raquew dos Santos. Mediações entre estudos culturais e comunicação: uma mirada conceitual. Trabalho apresentado no XXVI Congresso Anual de Ciência da Comunicação, Belo Horizonte, 2-6/9/2003.

BANCO CENTRAL DO BRASIL. Série histórica do PIB brasileiro. Disponível no site do Banco do Brasil, no endereço:

http://www.bcb.gov.br/pec/indeco/Port/ie1-51.xls. Último acesso: 16/12/2006.

CABRAL, Aline. Indicador de qualidade editorial: um foco na satisfação do leitor. Apresentação no IV Encontro Nacional da Sociedade Brasileira de Pesquisadores em Jornalismo, de 5 a 7/11/2006, em Porto Alegre. Disponível no endereço: http://www.sbpjor.ufsc.br/ivsbpjor/index.php?sbpjor=palestras.

Acessado em: 13/12/2006.

CASTELLS, Manuel e INCE, Martin. Conversations with Manuel Castells.

Cambridge: Polity Press, 2003.

CHAPARRO, Carlos. Em crise, o jornalismo busca novos papéis. Artigo no site Comunique-se, www.comunique-se.com.br. Acessado em 30/8/2004.

$\mathrm{COHN}$, Gabriel. A forma da sociedade da informação, in DOWBOR, Ladislau et alii. Os desafios da comunicação. Petrópolis, RJ: Vozes, 2000.

DALMONTE, Edson Fernando. Estudos culturais em comunicação: da tradição britânica à contribuição latino-americana, in Idade Mídia, São Paulo, ano I, n. 2, nov/2002.

DEUZE, Mark. Multimedia journalism: exploring the emergence of professional identity in converging newsrooms. In SALAVERRÍA, Ramón, e SÁBADA, Charo (editores). Toward new media paradigms: content, producers, organisations and audiences. Navarra: Edicciones Eunate, 2003.

DOWNIE JR., LEONARD e KAISER, ROBERT G. The news about the news:

American journalism in peril. Nova York: Alfred A. Knopf, 2002. 
DUARTE, Matsuuchi. Estudo de caso. In DUARTE, Jorge, e BARROS, Antonio (org.). Métodos e técnicas de pesquisa em comunicação. São Paulo: Atlas, 2005.

ESCOSTEGUY, Ana Carolina. Os estudos culturais. In HOHLFELDT, Antonio; MARTINO, Luiz C.; FRANÇA, Vera Veiga. Teorias da comunicação: conceitos, escolas e tendências. Petrópolis, RJ: Vozes, 2001.

FONSECA JR., Wilson Corrêa da. Análise do conteúdo. In DUARTE, Jorge, e BARROS, Antonio (org.). Métodos e técnicas de pesquisa em comunicação.

São Paulo: Atlas, 2005.

FULLER, Jack. News values: ideas for an information age. Chicago: The University of Chicago Press, 1996.

GATES, Dominic. Newspapers in the digital age. Online Journalism Review 1/5/2002. Disponível em: http://www.ojr.org/ojr/future/1020298748.php

HAMILTON, James T. All the news that's fit to sell: how the market transforms information into news. Princeton: Princeton University Press, 2006.

IMPRENSA. Mercado de revistas no Brasil. Número 218, edição de novembro de 2006.

JORNAL ANJ. Em lugar de circulação, audiência é novo conceito. Reportagem sobre palestra proferida por Martha Stone, da Associação Mundial de Jornais. Edição de outubro de 2006. Disponível em:

http://www.anj.org.br/jornalanj/?q=node/740. Último acesso: 13/12/2006.

JORNALISTAS \& CIA. Otavio Frias Filho. Série Protagonistas da Imprensa

Brasileira. Edição 1. 8/11/2005. Disponível, para assinantes, em

www.jornalistasecia.com.br

JORNALISTAS \& CIA. Lance unifica equipes de produção. Edição 561, de 11 a 17/10/2006.

JULIASZ, Fábia. A internet no Brasil. Apresentação na Associação Brasileira dos Provedores de Acesso, Serviços e Informações da Rede Internet (Abranet). Disponível no endereço:

http://www.abranet.org.br/doc/ApresUOLmaio 06FJ1.pdf. Último acesso:

16/12/2006. São Paulo, 24/5/2006.

KELLNER, Douglas. A cultura da mídia. Trad. Ivone Castilho Benedetti. São

Paulo: Edusc, 2001.

LEBLOGMEDIAS. Le prix de l'information em Irak. 25/10/2006.

http://www.leblogmedias.com/le blog mdias/2006/10/le prix de linf.html LOBATO, Elvira. Mídia nacional acumula dívida de $R \$ 10$ bilhões. Folha de São Paulo, 15/2/2004. Disponível em:

http://www1.folha.uol.com.br/folha/dinheiro/ult91u80746.shtml

LÓPEZ GARCÍA, Xosé. In NOCl, Javier Díaz \& SALAVERRÍA, Ramón (coords.). Manual de redacción ciberperiodistica. Barcelona: Ariel, 2003.

MEYER, Philip, The vanishing newspaper: saving journalism in the information age. Columbia: University of Missouri Press, 2004.

MORIN, Edgar. Introdução ao pensamento complexo. Trad. Dulce Matos. 3.. ed. Lisboa: Instituto Piaget, 2001.

NOCI, Javier Díaz \& SALAVERRÍA, Ramón (coords.). Manual de redacción ciberperiodistica. Barcelona: Ariel, 2003.

OLIVEIRA, Letícia Trois de. Indicadores de gestão editorial. Pesquisa feita para a Associação Nacional de Jornais. Agosto de 2006. Disponível em:

http://extranet.anj.org.br/palestras/cbj2006/LeticiaTroisdeOliveira.pdf. Último acesso: 13/12/2006. 
PAULINO, Raquel. "A separação entre anúncio e notícia é sagrada no jornal diário". Revista Imprensa. № 216, setembro de 2006ª. Pág. 78-79.

PAULINO, Raquel. "O bom e velho jornal". Revista Imprensa. № 216, setembro de 2006b. Pág. 82.

PROJETO INTER-MEIOS. Faturamento dos jornais no Brasil. Disponível no site do Projeto Inter-Meios, no endereço:

http://www.projetointermeios.com.br/controller.asp?acao=relatoriolnvestimento\# Último acesso: 12/12/2006.

SÁNCHEZ-TABERNERO, Alfonso. Dirección estratégica de empresas de comunicación. Madri: Ediciones Cátedra, 2000.

SEELYE, Katharine Q. 'LA Times' põe fim à edição nacional. O Estado de S. Paulo, trad. do New York Times, 16/12/2005. Pág. B15.

STIGLITZ, Joseph E., Information and the change in the paradigm in economics. Nobel Prize lecture, Columbia Business School, Nova York, 8/12/2001. Disponível em:

http://nobelprize.org/economics/laureates/2001/stiglitz-lecture.pdf

STONE, Martha. The backpack journalist is a 'mush of mediocrity'. Online Journalism Review, 2/4/2002. Disponível em:

http://www.ojr.org/ojr/workplace/1017771634.php.

THE WALL STREET JOURNAL. Redesigned Wall Street Journal hits newsstands today. 2/1/2007, Disponível em:

http://www.dowjones.com/Pressroom/PressReleases/Other/US/2007/0102 US TheWallStreetJournal 8660.htm, acessado em 2/1/2007.

THE WALL STREET JOURNAL. Publisher's Letter. 2/1/2007. Disponível em: http://www.dowjones.com/Pressroom/Presskits/NewJournal/NJ PubLetter 3.ht $\mathrm{m}$, acessado em 2/1/2007.

WESTIN, Ricardo. Chilena cria fórmula de avaliação de jornais. O Estado de S. Paulo, 29/10/2006. Pág. A18.

WURMAN, Richard Saul. Information anxiety. Nova York: Doubleday, 1989.

YIN, Robert K. Case study research: design and methods. Thousand Oaks:

Sage Publications, 1989. 


\section{BIBLIOGRAFIA CONSULTADA}

BAGDIKIAN, Bem H. Sociologia da comunicação: máquinas de informar. Trad. Nathanael Caixeiro. Rio de Janeiro: Civilização Brasileira, 1973

BARBOSA, Alexandre. Audiência online de jornais cresceu 21\% em 2005.

Portal do Estadão, 4/4/2006. Disponível em:

http://www.estadao.com.br/tecnologia/internet/noticias/2006/abr/04/180.htm BRIGGS, Asa e BURKE, Peter. Uma história social da mídia: de Gutenberg à internet. Trad. Maria Carmelita Pádua Dias. Rio de Janeiro: Jorge Zahar Ed., 2004.

CARDEAL, Maria Regina. Do jornal ao portal: estudo sobre a iniciativa de globalização do jornalismo brasileiro. Tese de doutorado. São Paulo: ECA/USP, 2003.

CASTELLS, Manuel. A sociedade em rede. Trad. Roneide Venâncio Majer. 4. ${ }^{\mathrm{a}}$ ed. São Paulo: Paz e Terra, 2000.

CASTELLS, Manuel. A galáxia da internet: reflexões sobre a internet, os negócios e a sociedade. Trad. Maria Luiz Borges. Rio de Janeiro: Jorge Zahar Ed., 2003.

DUARTE, Jorge, e BARROS, Antonio (org.). Métodos e técnicas de pesquisa em comunicação. São Paulo: Atlas, 2005.

HOHLFELDT, Antonio; MARTINO, Luiz C.; FRANÇA, Vera Veiga. Teorias da comunicação: conceitos, escolas e tendências. Petrópolis, RJ: Vozes, 2001.

SAAD, Beth. Estratégias para a mídia digital: internet, informação e comunicação. São Paulo: Editora Senac, 2003.

SAAD, Beth. O panorama contemporâneo das empresas jornalísticas brasileiras: crise de gestão ou reconfiguração de identidade? Paper apresentado em concurso para professor titular do Departamento de Jornalismo e Editoração da Escola de Comunicação e Artes da Universidade de São Paulo, São Paulo, janeiro de 2005.

SALAVERRÍA, Ramón, SÁBADA, Charo (edit.). Toward new media paradigms: content, producers, organisations and audiences. Navarra: Edicciones Eunate, 2003.

SÁNCHEZ-TABERNERO, Alfonso. El futuro de las empresas de comunicación: estrategias para un mundo impredecible. Documento xerografado, 2003. TEIXEIRA, Pollyana Ferrari. Jornalismo digital. São Paulo: Contexto, 2003. THORNBURN, David, e JENKINS, Henry. Rethinking media change: the aesthetics of transition. Cambridge: MIT Press, 2003. 


\section{ANEXOS - ENTREVISTAS}

\section{Sandro Vaia}

Diretor de Redação de O Estado de S. Paulo e diretor de Informação do Grupo S.A. O Estado de S. Paulo até outubro de 2006. Concedida no dia 9 de novembro de $2005 .{ }^{1}$

Está havendo uma queda de circulação nos três grandes jornais nos últimos anos. Na avaliação de vocês, é uma coisa que deve ser contida, que deve ser revertida ou é inexorável?

Acho que é uma tendência mais ou menos inexorável. A gente conseguiu deter a queda, mais particularmente o Estadão. Mas, pelo que eu verifico no IVC, acho que o Globo ainda não conseguiu nem a Folha conseguiu deter. Tem duas características básicas: depende do ano que você toma como referência. Porque no final dos anos 90, começo de 2000, teve aquele negócio de anabolizante. E a circulação dos jornais aumentou artificialmente de forma espantosa. A Folha chegou a 1 milhão de exemplares. Então, não vi ainda nenhum estudo concreto - nem aqui na nossa Circulação consegui isso - que expurgasse esses efeitos, para saber exatamente quanto foi a queda efetiva de circulação do jornal. Em termos nacionais, ela não caiu. Nos grandes jornais, há esse defeito de metodologia que inclui essa bolha que não sei como se fará para expurgar, não sei nem se os departamentos de circulação têm capacidade de fazer isso, de localizar quando começou, quando chegou no auge, quando voltou a zero, para retomar o período verdadeiro. De qualquer forma, acho que é uma tendência mais ou menos mundial, só que, nos outros países, é muito mais lenta, aparentemente menos dramática do que aqui. Nos Estados Unidos, no ano passado (2004), foi algo como 0,2\%. Na Europa, é uma tendência mais na França e na Itália. Na Inglaterra, pelo contrário, a mudança para tablóide aumentou a circulação dos grandes jornais. O Guardian acabou de fazer uma mudança, parece que aumentou $30 \%$ a circulação. O Figaro mudou há um mês (outubro) o formato. Le Monde mudou de cara ontem (8/11/2005), fazendo um

\footnotetext{
${ }^{1}$ Ao anunciar a substituição de Sandro Vaia, em outubro de 2006, o presidente do Conselho de Administração do Grupo Estado, Roberto Crissiuma Mesquita, informou que seriam mantidas as diretrizes do jornal, tanto no campo editorial quanto gerencial. De maneira que, em princípio, as teses de Vaia, aqui expressas, seguiram valendo para o Estado.
} 
jornal mais amigável, com mais fotos, menos textos. Ninguém absolutamente esperava um negócio desses do Le Monde. A tendência é fazer com que a natureza do jornal vá mudando aos poucos. O jornal de hard news desaparece, e passa a ser um jornal de análise, de comentário, para quem quer saber mais, para quem quer se aprofundar na informação.

Você acha que ele diminui de tamanho?

Acho que inexoravelmente diminui. Primeiro, porque, financeiramente, é insustentável fazer jornais enormes. Segundo, porque grande parte da publicidade que sustenta os jornais provavelmente vai migrar para meios eletrônicos. É o que já está acontecendo, em alguns casos. O Google, hoje, é um dos maiores receptáculos de publicidade do mundo: US $\$ 6$ bilhões, no ano passado (2004), com aqueles anúncios dirigidos que eles têm. Então, acho que a natureza do jornal vai mudando, aos poucos. Mas não acredito que ele seja substituído definitivamente, totalmente, pela mídia eletrônica. Não dá, por questão até física, de portabilidade, de facilidade de manuseio. E pela sua própria natureza. É difícil você tentar se aprofundar numa reflexão, numa análise, em um meio eletrônico. Você usa o meio eletrônico para hard news, para notícia rápida, para notícia curta, instantânea. Os jornais têm de se conscientizar de que não podem ficar repetindo, no dia seguinte, aquilo que todo mundo já sabe.

Você falou em opinião e análise, mas você tem dado muita ênfase à reportagem no Estadão, não é?

É. Acho que contar histórias e contextualizá-las, dando sentido, é a saída dos jornais. Achar coisas diferenciadas, aprofundar discussões que a mídia eletrônica não pode aprofundar. Mostrar verdadeiramente o país em que a gente vive. Por isso que a gente põe esse nome "Retratos do Brasil" em várias das reportagens que a gente tem feito. Acho que é o caminho do jornal. Ficar no jornalismo declaratório, na repetição, no factual do dia anterior é a morte certa. Não tem por que comprar jornal. As pessoas não se sentem obrigadas nem necessitadas de comprar jornal.

O atual nível de rentabilidade e o atual número de assinantes e leitores asseguram a saúde financeira do jornal? 
Acho que um jornal saudável, com circulação e influência fortes, ainda é rentável durante muito tempo. Mesmo investindo em qualidade, que eu acho que é o que os jornais têm de fazer, provavelmente trocando a quantidade pela qualidade: em vez de ter redações imensas de 500 pessoas, uma redação mais enxuta, com metade das pessoas, melhor preparadas, mais bem pagas. Acho que essa é a solução. O negócio, em si, ainda é rentável. Segundo números que a (empresa de consultoria em gestão) McKinsey apresentou para nós na semana passada, a rentabilidade média no mundo é de $25 \%$ e a dos jornais brasileiros, entre 10\% e 20\%. Estamos ainda dentro desse patamar.

Você herdou aqui uma estrutura muito grande, voltada para o dia-a-dia, e está pensando em aproveitar essa estrutura, numa transição, e usá-la também para o meio eletrônico e os outros meios do Grupo Estado?

Fazer uma integração mais aprofundada entre as estruturas. Acho que não tem sentido você ter um portal do Grupo Estado que faça um jornalismo que corra ao largo do jornal de papel e da filosofia do grupo, como grupo informativo. Não vejo por que as redações não possam trabalhar integradas. Não quero que as pessoas façam trabalho duplicado. Quero que trabalhem com a mesma cabeça. A integração é nesse sentido, não é despedir 30 e fazer os outros 30 fazerem 0 trabalho daqueles que foram embora. Ainda há que achar a mecânica do funcionamento disso. O próprio New York Times anunciou essa integração, mas só vai se completar em 2007, se não me engano. Vamos achar o caminho fazendo. A intenção de fazer é que acho importante. A maneira de fazer, vamos ver, no decorrer do caminho.

E fisicamente vai...

Fisicamente juntos, porque acho que tem que respirar o mesmo ar - a filosofia é a mesma para todos os meios - e vibrar na mesma intensidade, tanto a redação de papel, em tempo diferido, como a em tempo real. Seria até ideal que a redação da Agência Estado estivesse mais próxima fisicamente da gente também, até para a gente poder interagir mais facilmente.

Todos os editores, chefes de reportagem deveriam se juntar?

Devem se juntar. O ideal seria que as redações todas se juntassem, mas há uma questão de espaço físico, não foi planejado para isso. Mas vamos fazer 
um mesão de comando operacional conjunto e vamos começar a trabalhar mais juntos ${ }^{2}$. Provavelmente a redação da agência virá para cá. $O$ prédio tem muitos vazios. Não sei como serão acomodados, mas ficarão fisicamente mais próximos. Acho que fará mais sentido.

E a televisão, entra nesses planos?

A televisão é uma coisa complicada. A família acionista ainda não decidiu o que fazer com ela. Tem a concessão, tem o canal. Por enquanto, é apenas uma retransmissora, não é uma geradora. Está obrigada a gerar meia hora ou uma hora de programação própria por dia. Mas é uma decisão estratégica do grupo, se vai achar um parceiro. Isso está sendo discutido no nível dos acionistas. É uma decisão empresarial.

Com a experiência que você tem da Agência Estado ${ }^{3}$, e agora do jornal, você acredita que, mesmo continuando a existir o jornal de papel, vá surgir um meio convergente, algo entre televisão e computador?

Provavelmente vá haver uma convergência, mas acho que um meio fisicamente tão amigável como o jornal de papel não tem como. Por isso acho que ele tem vida longa, como o livro. Dificilmente alguém vai ler um livro numa tela de televisão. A comodidade física é muito importante.

Você investiu recentemente na reforma gráfica do jornal'. Você atribui a isso, em parte, o fato de a queda da circulação ter sido contida?

Também. Porque o jornal ficou um pouco mais abrangente, o jornal tenta ser um pouco mais amigável também. Deixa de ter aquele ar sisudo, aquele ar de seriedade - que é uma coisa um pouco mais de percepção do que de realidade. O Estadão tem essa imagem. E é difícil mudar imagem: "Ah, o Estadão é um jornal chato, pesado." Você precisa não só mudar como mostrar para as pessoas que mudou, até elas se convencerem de que realmente mudou. Outra coisa que também está em discussão, agora, no planejamento estratégico da empresa, é a questão da circulação. Houve uma decisão

\footnotetext{
${ }^{2}$ Implementado em setembro de 2006, esse "mesão" reúne a chefia de reportagem, a chefia de domingo, a equipe de primeira página, a chefia do portal, a coordenação de correspondentes e a chefia de redação.

${ }^{3}$ Antes de assumir a direção de redação do Estado, em outubro de 2000, Vaia era diretor da agência.

${ }^{4}$ O Estado estreou com o seu novo padrão gráfico em 12/12/2005
} 
deliberada da empresa de concentrar a circulação em São Paulo, porque é o grande mercado publicitário, o leitor do Estado está aqui, e a circulação fora de São Paulo é cara. O Estadão desinvestiu deliberadamente na circulação no interior de São Paulo e outras capitais. Tanto que a liderança da Folha de circulação é toda fora de São Paulo. Na cidade de São Paulo e na Grande São Paulo, o Estado lidera ainda. É uma pequena liderança, mas lidera em circulação. O grande gap está no interior de São Paulo e nas capitais. Isso foi uma decisão empresarial por questões financeiras. $E$ isso está sendo rediscutido porque se volta ao conceito de que realmente é a circulação que acaba redundando em influência, principalmente junto a formadores de opinião. Não queremos uma circulação massiva, por ser massiva, como se tentou durante anos, na época dos anabolizantes. É chegar aonde as pessoas que importam, tenham que ler, sejam obrigadas a ler o jornal.

Aí, a razão não é contábil, é de influência. É uma mudança de paradigma...

Exatamente. Aí, não se passa mais a considerar como custo por mil, para anunciante, etc. Mas como um jornal influente e importante. É evidente que é importante anunciar num jornal importante. Para o anunciante, isso quer dizer muita coisa. Se o jornal deixa de circular em centros de influência - São Paulo, Rio de Janeiro, capitais - e junto a públicos formadores de opinião, universitários, tomadores de decisão, empresários, ele perde influência. Perdendo influência, evidentemente, perde circulação, e perdendo sua circulação, perde sua eficácia como veículo de publicidade.

Você também inovou na questão da gestão profissional. O Estadão saiu na frente nisso. Isso também é irreversível?

A família Mesquita tomou uma decisão de profissionalizar a gestão da empresa e está seguindo essa decisão plenamente. Está dentro do cronograma deles, e tudo está sendo feito de acordo com a decisão tomada pela maioria dos acionistas da empresas.

Eles estão contentes? A tendência é manter esse arranjo?

Acho que eles estão satisfeitos com os resultados. A empresa ficou saneada financeiramente, renegociou a dívida, está saudável, tem um horizonte para terminar de pagar a dívida num prazo " $x$ ". Nesse período, não poderá investir 
muito, porque o primeiro compromisso é o de pagar a dívida. Mas é uma empresa no caminho da profissionalização plena.

Essa profissionalização e esse saneamento não significam deixar de ter certos caprichos de jornalista. Você citou agora a circulação nacional, que é um valor intangível: querer que o jornal tenha prestígio, tenha influência, são coisas que não se podem pôr num power point, muitas vezes. Então, você acha que dá para fazer isso: ao mesmo tempo, pensar em saneamento, lucratividade, rentabilidade, e pensar em termos jornalísticos?

Exatamente. Eu acho que uma coisa tem que estar inevitavelmente, inexoravelmente, amarrada à outra. Acho que não precisa ter uma circulação superfaturada. Basta ter uma circulação que atinja as camadas $A, B$, tomadores de decisiões, formadores de opinião, que nos interessa ter.

O que os leitores têm dito (nas pesquisas) sobre os jornais de domingo? As revistas se têm mantido num patamar elevado de circulação. Você acha que o jornal de domingo deve se aproximar mais da revista em linguagem, em formato, com produto, ou deve manter a identidade?

Acho que os jornais estão se "arrevistando", porque é a característica do fimde-semana, a pessoa está cansada do hard news, cansada das notícias utilitárias do dia-a-dia, e quer uma coisa mais relaxada. As revistas, principalmente, no nosso caso, a Veja, conquistaram uma fatia de mercado muito grande, acho que até como parâmetro mundial. A Veja tem mais de 1 milhão de exemplares. Ela conseguiu encontrar esse nicho, encaixou-se nesse nicho. Embora esteja conhecida atualmente pelas reportagens políticas, denúncias polêmicas, durante o tempo de não crise, tem investido muito em matérias de saúde, vida pessoal, comportamento. Provavelmente foi isso que abriu esse nicho. Embora as denúncias sejam importantes, não foi isso que fez aumentar a circulação. O que fez aumentar a circulação foi exatamente o contrário: a parte leve, a parte comportamental. E também as pessoas com pouco tempo para se informarem, durante a semana, consideram que, lendo a revista semanal, está tudo sabido, se dão por bem informadas, com aquilo que é um resumo da semana.

O caderno Aliás supre isso? 
É, o Aliás foi um pouco para suprir isso. Além de fazer um resumo breve da semana, na página 2 dele, também rediscute assuntos da semana que tenham passado despercebidos. Ele aprofunda a discussão, por outros ângulos, por outras abordagens, sobre os temas principais da semana.

Você acha que o portal (na internet do Grupo Estado) pode alavancar a leitura da internet, e vice-versa?

Acho que pode, sim. Como a televisão durante muito tempo foi um abridor de apetite para o consumidor de informação. Quer dizer: para que precisa consumir informação? Não simplesmente para saber os títulos daquilo que está acontecendo, mas, para entender as coisas, a televisão sempre foi um motivador. Você vê a notícia no Jornal Nacional e espera o jornal do dia seguinte para se aprofundar, para entender direito essa notícia. Acho que a internet, o portal pode ter um pouco essa função.

Os novos cadernos, como o Paladar ${ }^{5}$, também foram pedidos dos leitores, nas pesquisas?

O leitor, na pesquisa, normalmente não sabe definir exatamente o produto que ele quer. A gente capta o estado de espírito dele, e procura atendê-lo com produtos que a gente formata da cabeça do jornalista. $\mathrm{Na}$ verdade, o leitor gosta de ser surpreendido. Ele pode dar mil palpites sobre o jornal, mas ele espera que os profissionais façam para ele prato pronto que ele acabe gostando. Mas isso nasce de inputs, de expectativas. Gastronomia está na moda, está na cabeça das pessoas, virou hobby de muita gente, virou negócio importante. Juntando todos esses fios, sai um produto como o Paladar, muito agradável.

No caso de cadernos temáticos, como esses das regiões $\rho$ Novo Mapa do Brasil, cadernos especiais sobre as cinco regiões do País, com enfoque em economia e negócios), que outras publicações também fazem, a Gazeta Mercantil fez uma época, a Economist faz as Surveys, eles atraem publicidade, mas existe o risco de eles ficarem com cara de coisa comprada?

A gente tem muito receio em cima disso. Inclusive, tomamos muito cuidado, ao elaborar a pauta, ao acompanhar a própria venda de publicidade. A gente fez

\footnotetext{
${ }^{5}$ Lançado em 22/9/2005.
} 
questão de esclarecer ao pessoal da área de publicidade que se trata de um produto editorial, que tem que ser vendido pelos méritos editoriais dele, e não porque vá falar bem de alguém, ou porque vá defender alguma tese. Isso contrariaria toda a história do Estado de São Paulo, que nunca usou esse tipo de recurso para receber anúncio. A idéia do Novo Mapa do Brasil, por exemplo, nasceu na Agência Estado. O pessoal da agência, que é mais ligado à área econômica, detectou que existe uma migração de oportunidades de investimentos dentro do Brasil. Dificilmente dá para mostrar isso no meio eletrônico, nas formas que eles têm de distribuir informação. Isso teria que se materializar num caderno de jornal. Eles produziram a pauta, a gente contratou uma equipe de jornalistas de fora, experientíssimos, vindos da Exame, jornalistas muito sérios, muito respeitados. $\mathrm{E}$ a gente lançou esse produto com esse objetivo, mesmo: de mostrar onde estão as oportunidades de investimentos no Brasil.

Essa separação entre o comercial e o marketing, de um lado, e a redação e o editorial, do outro, é um muro que a internet tem tentado derrubar. Você acha que esse muro tem que continuar de pé?

Acho que esse muro é absolutamente intransponível. O que você pode fazer é melhorar as relações cordiais. Redação e comercial não podem ser inimigos. Mas são eles lá e a gente aqui. A gente pode dar idéias para eles, eles nos darem idéias de produtos, e ponto final. É "Igreja e Estado" mesmo (referência a expressão cunhada pela revista Time). Igreja e Estado com relações cordiais. Não precisamos nos matar por causa disso.

Você citou as experiências com formatos na Inglaterra. Você acha que se deveria tentar alguma coisa nesse sentido no Brasil?

No plebiscito do desarmamento (23/10/2004), fizemos um produto com um tamanho meio peculiar: não era nem tablóide nem berliner nem meio tablóide. Foi uma experiência. Pedi para o pessoal da Circulação fazer uma pesquisa rápida por telefone, ouvir entre 60 e 70 pessoas para ver o que acharam; 90\% adoraram o formato. Mas porque era um suplemento. Fazer um jornal com formato diferente, no Brasil, fora do Rio Grande do Sul, que tem essa tradição, sabe-se lá por quê, acho complicado. Por outro lado, produzimos um número zero do que seria uma edição do JT em tablóide, foi submetido a uma 
pesquisa, e não agradou. Aqui, é muito complicado, porque não tem a cultura do tablóide, ao contrário da Inglaterra, que fez essa transformação com uma rapidez incrível, e foi um sucesso. É que lá as pessoas estão acostumadas a manusear no metrô. Aqui, não há essa tradição. 


\section{Otavio Frias Filho}

Diretor de Redação da Folha de São Paulo e diretor editorial da Empresa Folha da Manhã S.A. Concedida no dia 10 de novembro de 2005.

Nos últimos quatro anos, houve uma queda na circulação dos três grandes jornais. Parece que este ano 2005) está havendo uma certa recuperação. Você acha que se pode almejar chegar a circulações altas, como as que houve no fim da década? O que se pode esperar, em termos de circulação?

Eu acho que em meados da década passada, estendendo-se para perto do final dos anos 90 , houve efetivamente aquele pico de circulação dos jornais, chegaram ao apogeu, em decorrência da política de promoções que foi adotada a partir de 93/94 pelos principais jornais. Os jornais passaram a agregar produtos, quase sempre de natureza cultural - atlas, enciclopédias, dicionários -, vinculando a compra desses produtos, a preço muito acessível, à compra do jornal. Isso respondeu por um acréscimo bastante artificial da circulação. No caso da Folha, chegamos a um recorde de 1,5 milhão de exemplares, num determinado momento de 1995, se não me falha a memória. Nesses anos, nós tivemos de fato uma circulação média por volta de 600 mil exemplares. Voltar a esse patamar, até onde posso ver as coisas, é um objetivo um pouco fantasioso. A política de promoções se esgotou. Ela tinha limites estruturais. Também tinha limites da parte do consumidor, a chamada prosaicamente "teoria da prateleira": não cabem mais produtos na prateleira e o consumidor deixa de colecionar. Mas uma recuperação em relação a essa queda que houve nesses primeiros anos da década em curso, acho um objetivo bastante factível, não vejo por que não se devesse ambicioná-lo. A sensação que tenho é a de que o decaimento da circulação dos principais jornais do ano 2000 para agora - queda essa que eu estimo por volta de $20 \%$ se deveu, evidentemente, a vários fatores, mas, na minha leitura, o principal fator foi a contingência de que as empresas tiveram que mudar sua política. Nos anos 90, as empresas de comunicação estavam em um movimento expansionista. Fizeram investimentos, procuraram não perder o bonde da história, embarcando, da forma como podiam, em investimentos em novas mídias, havia toda uma ideologia de que as empresas de comunicação que não se diversificassem e não aproveitassem as oportunidades propiciadas pela 
chamada "revolução digital" estariam cometendo um grave erro estratégico para o futuro. Então, foi um período de grande expansão, de muito investimento, as empresas se endividaram, houve uma reversão do ambiente econômico em 1999, a desvalorização da moeda, as dívidas assumiram proporções galopantes, se transformaram em espécies de bolas de neve. Houve também o estouro da bolha de internet - uma conjunção, efetivamente, de fatores, que determinaram um novo comportamento no panorama das empresas de comunicação a partir de 2000. Em vez de investir, passourse a desinvestir, cortar despesas, vender ativos. Tudo com o objetivo, que passou a ser prioritário, de aumentar o resultado, de modo a fazer frente à avalanche da dívida, que se avolumava, inclusive em função da política de juros que passou a ser praticada no Brasil. Então, a prioridade, a partir de 2000, passou a ser vender ativos, interromper investimentos e, sobretudo, cortar despesas, o que foi feito de maneira drástica pelas empresas. Na medida em que você tira o pé do acelerador, para usar uma metáfora, você perde, evidentemente, capacidade de venda no mercado. As empresas reduziram muito os seus orçamentos de marketing, suas equipes de telemarketing, o poder de fogo dos seus departamentos de assinaturas, e perderam poder de agressão no mercado. E eu quero crer que esse é o principal fator que levou a essa queda da ordem de $20 \%$, em alguns casos de $25 \%$, de 2000 até o ano passado.

Os grupos Abril e Globo também enfrentavam essas dificuldades, essas dívidas, por razões até parecidas. No entanto, a leitura de revistas tem aumentado. Surgiu uma revista nova, que se acomodou no mercado sem roubar leitores de Veja e Istoé. Época criou um novo mercado e simultaneamente o leitorado dos jornais estava diminuindo. Será que há também um deslocamento do leitor para uma leitura de fim de semana, em alguns casos mais agradável, mais resumida, que demanda menos do leitor, que se sente menos obrigado a ler jornal - e aí uma questão um pouco também geracional?

Acredito que, em alguma parcela, possa ocorrer esse fenômeno que você descreveu. Mas eu problematizaria um pouquinho a premissa. Primeiro: a Época teve um lançamento espetacular, em termos de circulação. Foi uma circulação também muito impulsionada por políticas de promoção, com uma 
série de concessões ao anunciante novo, etc.. E, depois, a Época desinflou. A curva de circulação da Época a partir do lançamento é descendente. Logo depois do lançamento, talvez seja o formato de um sino. Ela lançou, subiu bruscamente e depois também caiu fortemente. A circulação da Época hoje está pouco acima de 400 mil. No caso da Veja, tenho também a sensação de que, ao longo dos últimos quatro, cinco anos, é uma circulação relativamente estável, na casa de 1 milhão, 1,1 milhão. A Istoé também está num patamar estável, em torno de 300 mil $^{6}$. Então, não sei se está correta essa premissa de que as revistas semanais de informação tiveram uma expansão de circulação no período. Embora, evidentemente, elas tiveram um desempenho comparativamente melhor em relação ao que os jornais apresentaram. Eu acrescentaria um outro aspecto como capaz de auxiliar na explicação de por que isso aconteceu. As revistas efetivamente mudaram muito de política editorial. Na minha leitura, pelo menos, no final dos anos 90 , as revistas fizeram uma inflexão muito abrupta, que os jornais jamais fizeram, na direção de conferir um atendimento quase que sem restrições às demandas imediatas do público consumidor tal como essas demandas apareciam em pesquisas de opinião. Então, o público quer mais lazer, cultura do corpo - fitness, ginástica -, saúde, dietas? As revistas deram isso. As revistas se curvaram, a meu ver, de forma muito acrítica, no limite até desfigurando a sua identidade como veículos de opinião, ditos de qualidade, com determinado compromisso com certas questões públicas, com sua própria tradição editorial. Tenho a impressão de que as revistas deixaram tudo isso um pouco em segundo plano para atender a demandas estritamente de mercado, num atendimento que me parece que foi automático, cego, acrítico, tipo: "É isso que o leitor quer, é isso que vamos dar." As revistas se despolitizaram, perderam essa dimensão mais pública, passaram a incidir, com uma freqüência enorme, numa temática que eu costumo chamar, um pouco de brincadeira, de individualismo possessivo, lembrando uma expressão usada pelo $(C B)$ Macpherson, o cientista político canadense dos anos 70. Por individualismo possessivo, entendo essa cultura de shopping center, cultura mais aquisitiva, mais narcisista, mais personalista,

\footnotetext{
${ }^{6}$ De acordo com o Instituto de Verificação da Circulação, em junho de 2006, a tiragem das três revistas era a seguinte: Veja, 1,089 milhão; Época, 433 mil; Istoé, 343 mil. Fonte: revista Imprensa, ํㅡㄴ 218, de outubro de 2006, p. 78
} 
preocupada com "meu emprego, minha carreira, meu plano de saúde, a faculdade do meu filho", etc. Acho que essa inflexão que as revistas deram provavelmente garantiu um certo gás de circulação que faltou aos jornais até porque eles se recusaram a fazer esse tipo de inflexão. Os jornais vêm sendo também contaminados por essa demanda, e eu acho pessoalmente até bom que eles saiam da torre de marfim em que eles muitas vezes ficam, e prestem mais atenção àquilo que o leitor majoritário quer. Mas os jornais, a meu ver, nunca fizeram uma inflexão tão drástica e tão concessiva quanto aquela que as revistas fizeram.

Essas demandas aparecem nas pesquisas que a Folha faz? Os leitores pedem menos hard news, menos política, menos economia e mais saúde, cotidiano, etc.?

Sem dúvida. Sobretudo nas pesquisas qualitativas, quando, pela própria natureza da pesquisa, você pode ter um vislumbre um pouco mais compreensivo da psicologia do leitor. As pesquisas quantitativas são muito úteis, mas são bidimensionais. As pesquisas qualitativas dão essa terceira dimensão, de uma perspectiva psicológica das motivações, dos porquês dos leitores. Essa pressão aparece muito. Em termos mentais, para meu consumo pessoal, costumo esquematizar da seguinte forma: cerca de $15 \%$ a $25 \%$ dos leitores têm um perfil que presumo mais "tradicional". É um leitor mais qualificado, mais bem informado, mais exigente, mais crítico em relação à sociedade, à política e ao próprio jornal. É um leitor que freqüentemente lê mais de um jornal, às vezes três. E é um leitor que tem um interesse e uma identificação maior pelos temas tradicionalmente nobres do jornalismo: política, macroeconomia, política internacional, etc. E você tem um grande grupo restante, que na minha estimativa um pouco empírica responderia pelos restantes $80 \%$, grosso modo, do leitorado, que é um público com outras características: é menos politizado, tem menos tempo para ler jornal, tem menos paciência, também, para ler os jornais, que, de fato, são, muitas vezes, muito cifrados para a maioria dos leitores. É um público que faz uma leitura, digamos, não só mais rápida, mas mais utilitária, mais seletiva do jornal. Vai ler certas partes, certas seções, certas colunas, etc. Dito isso, e fazendo uma autocrítica, acho que nós, jornais, atendemos razoavelmente bem aos 
primeiros $20 \%$ e atendemos bastante mal aos restantes $80 \%$, até porque nós, até pouco tempo atrás, não conhecíamos muito bem as características das demandas desse público majoritário.

De qualquer maneira, levando em conta a crítica que você fazia às revistas, fazer jornalismo não se trata de fazer $100 \%$ de concessão às pesquisas, há algo de ativo no trabalho de edição...

Exato, acho que o atendimento cego e total ao que aparece nas pesquisas pode ser muito bom por um prazo. No médio e longo prazos, tende a desfigurar a identidade do veículo ao longo do tempo. E acho que a identidade cultural, ideológica, imagética, digamos, de um jornal, é um elemento muito importante do produto, inclusive se você olhar sob o prisma do aumento do desempenho econômico, do mercado, etc. Não só sob o prisma do conceito de jornalismo, mas é importante até como ingrediente do desempenho econômico dos jornais.

Você vê também alguma diferenciação de faixa etária, com os mais jovens estando mais entre aqueles $80 \%$ e os mais velhos, entre os $20 \%$ ?

Sim, acho que existe essa superposição que você descreve.

Nesse caso, isso é um problema para o negócio jornal, ou será que os mais jovens, que estão entre os $80 \%$, ao envelhecer, vão ingressar nos 20\%?

Existem as duas teorias. Eu tendo a achar que há um pouco de verdade em cada uma. As gerações mais novas não estão muito dispostas a ler jornal, até porque hoje ele está imerso num ambiente muito mais competitivo, do ponto de vista da oferta de informação, de entretenimento escrito, etc. Nem preciso mencionar as novas modalidades, os novos formatos, o iPod, a internet, a comunicação por celular, etc. Num ambiente competitivo sobra menos tempo e dinheiro no bolso do consumidor para cada um dos vários tipos de comunicação e de informação, inclusive jornalística. E acho que as pessoas, de certa forma, estão amadurecendo mais tarde, nesse sentido específico. Noutros sentidos, claro, estão amadurecendo mais cedo. Mas em relação, por exemplo, ao período em que eu era estudante, percebo nitidamente que as pessoas saem muito mais tarde da casa dos pais, até por pragmatismo econômico. As pessoas evidentemente estão se casando e tendo filhos muito mais tarde. Então, acho que não é mero wishful thinking alimentar a 
expectativa de que uma parte desses jovens que hoje parece refratária à leitura dos jornais será um componente de late comers num universo futuro de leitores de jornal. Agora, acho que é necessidade de realismo reconhecer que muito provavelmente isso valha apenas para uma parte dos jovens. E provavelmente uma parte minoritária.

O jornal está estruturado, em termos de redação e de cultura, para contar para o leitor o que aconteceu ontem. No entanto, o leitor já sabe o que aconteceu ontem, porque tem internet no escritório, ouve rádio, vê TV à noite, pelo próprio celular, é bombardeado sobre o que está acontecendo. Você acha que deve haver uma transição para uma mudança de estrutura e de mentalidade sobre o que o jornal deve trazer para o leitor?

Menciono três aspectos, na tentativa de te dar uma resposta. Desde logo, sim. Os jornais precisam, na medida do possível, em algum grau, abandonar a cultura do "aconteceu ontem", e investir mais em histórias próprias, na medida das suas possibilidades, em histórias exclusivas, dar mais dimensão para a contextualização da notícia, dar mais visibilidade para aquilo no que os jornais são muito bons, que é a análise, opinião, crítica. Os jornais continuam produzindo um tipo de jornalismo que, comparativamente, é muito qualificado. O jornalismo de internet, de um modo geral, tem outras características vantajosas, de instantaneidade, de rapidez, mas, em termos qualitativos, ele não sustenta uma comparação com o jornalismo dos jornais e nem acredito que esse deva ser o propósito do jornalismo de internet, pelo menos para o jornalismo online. Então, acho que os jornais deveriam, sim, olhar menos para o que aconteceu ontem. Numa segunda parte da resposta, no entanto, o "aconteceu ontem" continua tendo uma certa importância para os jornais, porque acredito que, para uma parcela do público, informar-se a respeito do que aconteceu de relevante, capaz de interessar em tese qualquer pessoa alfabetizada num espaço de 24 horas, é o bastante. Quer dizer, acho que há uma parcela de pessoas que não tem necessidade de estar sabendo às $4 \mathrm{~h}$ o que aconteceu na CPI, daí às 5 h o que aconteceu na entrevista do Palocci, daí às 6h... Há uma massa, grande até, de pessoas, que vai continuar reservando um momento do dia para se informar do que aconteceu de relevante nas 24 horas anteriores. Então, acho que os jornais deveriam dar menos importância 
ao "aconteceu ontem", mas isso não significa simplesmente revogá-lo ou ignorá-lo. Acho que, muitas vezes, o "aconteceu ontem" continua precisando estar nos jornais por conta dessa parcela do público que não é consumidor pesado de informação. E um terceiro aspecto é que o "aconteceu ontem" precisa estar lá, até para que seja objeto de análise, contextualização, opinião, crítica, etc.

A reação dos jornais a essa massa de estímulos e inicialmente ao êxito da televisão - eu lembro o USA Today - foi imitar a televisão, até em termos visuais, para não perder leitores. Outro caminho seria fazer um jornal para aqueles que gostam de ler. Nesse balanço entre tradição e adaptação, você acha que a tendência é mais conquistar quem quer ler jornal?

Eu acho que tem que ser uma política mista, não de 8 ou 80 . Claro que os jornais precisam continuar apostando na força da palavra escrita. Embora nossa civilização continue sendo cada vez mais uma cultura visual - isso vem ocorrendo nos últimos 300 anos, embora se tenha acentuado muito dos anos 50 do século passado para cá -, o próprio advento da internet implicou um renascimento da palavra escrita. As pessoas voltaram a ler, e sobretudo a escrever, numa freqüência que estava extinta. Ninguém mais escrevia carta, praticamente. Hoje em dia, todo mundo escreve email, mensagem, posta respostas, Messenger, enfim, todas essas formas de comunicação escrita eletrônica. E as pessoas, embora estejam lendo na internet, segundo as pesquisas que eu conheço, de maneira errática, fragmentária, muito pessoal, caprichosa, idiossincrática, tenho a impressão de que elas estão lendo bastante. Porque o tempo que elas estão usando para ficar na internet, pelo que eu também conheço das pesquisas, é um tempo que está sendo roubado um pouco da televisão, um pouco da música, um pouco do próprio jornal, e a internet é uma cultura que tem esse elemento escrito, uma certa ressurreição, se você quiser, da palavra escrita. Surgiram esses dialetos novos, o internetês, etc. Acho que, embora os jornais devam se basear muito na idéia da palavra escrita, não dá para ignorar que vivemos num mundo visual, de imagens. Então, acredito que a tendência continue sendo - como aliás tem sido ao longo dos últimos 10, 20 anos - de os jornais perderem massa de texto. Eles tinham perdido, e acho que continuarão perdendo. A tendência histórica é a de os 
jornais serem menores do que foram nos anos 80 e 90, quando houve a expansão física das edições. Acho que eles vão se tornar menores, até por razões econômicas, de custo. A operação mecânica de fazer jornal, de "transportar átomos", para usar a linguagem de Nicholas Negroponte (diretor do Massachusetts Institute of Technology, MIT), é muito cara. Então, acho que os jornais vão diminuir de tamanho, e a tendência que já vinha acontecendo nas últimas décadas, de perda de massa de texto, prosseguirá. Porque é uma cultura visual, pela lei do menor esforço, as pessoas não têm tempo, não têm paciência. $O$ hábito adquirido de fazer o tipo de leitura mais tradicional, a figura clássica do sujeito que, na hora do café da manhã, pega os jornais, e vai ler meticulosamente página por página, e vai gastar duas horas, duas horas e meia lendo jornal, não existe mais, ou pelo menos está reduzida a um contigente minguante de leitores.

E esse jornal a que você se refere é o de tinta sobre papel, não é?

Sim, estamos falando até agora sobre jornal sobre papel, embora eu ache que o suporte tem implicações importantes do ponto de vista empresarial e econômico. Do ponto de vista jornalístico, é menos importante.

Conforme você afirmou recentemente ${ }^{7}$, impressão e distribuição representam 40\% dos custos da Folha, e a migração do papel para o suporte eletrônico representaria um alívio do ponto de vista empresarial, correto?

Sim.

Agora, do ponto de vista jornalístico, você vislumbra aquele profissional de mochila, com uma câmera digital, uma filmadora e um gravador, preocupado em nutrir todos os meios, provavelmente uma multimídia, no caso de vocês, o UOL, que produza para as diversas demandas do grupo, havendo, nesse sentido, uma mudança radical no trabalho do jornalista?

Essa figura já existe de forma, digamos, marginal, com free-lancers, por exemplo, que fazem algo assim. Mas é possível que essa figura venha a ganhar mais proeminência no ambiente da mídia. Há uma certa tendência de fusão das redações. Vários jornais já estão fazendo isso. Quem não está fazendo está pensando seriamente em fazer. Mas, aí, o objetivo é sobretudo

\footnotetext{
${ }^{7}$ Em entrevista concedida a JORNALISTAS \& CIA, em 8/11/2005.
} 
ditado por razões de custos, ou de "sinergia", para usar o eufemismo que o pessoal gosta de usar.

Não há esse plano aqui?

Estamos discutindo isso também, avaliando os prós e contras. Pessoalmente, estou com a sensação de que essa tendência de fusão talvez seja inarredável.

Em relação à edição, os consumidores de informação pela internet estão criando um espaço de interatividade, de uma certa interlocução, uma capacidade de colocar informações no ar, interagir, e deixar de ser apenas receptores e passar a ser emissores também. Há softwares de rating, nos quais se vota nas matérias por sua importância, o que já é um trabalho de editor atribuído ao leitor. Você acha que o jornalismo online pode caminhar nessa direção e diminuir um pouco o protagonismo do jornalista?

Você diz na direção de um jornalismo personalizado?

No caso do jornalismo online, o usuário é o mesmo da internet, e vai entrar no jornal online com o mesmo tipo de expectativa e de demanda do usuário de internet, e vai exigir que o jornal proporcione uma certa capacidade de entrar e de colocar suas visões, interferir um pouco na edição.

Acho que, em termos de interação, isso já está ocorrendo, e tenderá a ocorrer. Embora também não me pareça que vá atingir uma parcela majoritária dos consumidores de informação. Isso exige tempo, numa época em que o tempo é muito escasso e muito disputado. Então, acho que isso já está ocorrendo, mas duvido que essa prática interativa venha a ser uma prática comum, majoritária, da parte do consumidor de informações na internet. $E$ além de uma ou duas ressalvas que fiz em relação ao futuro do chamado jornalismo personalizado, esqueci de mencionar, no depoimento para o pessoal do Jornalistas \& $\mathrm{Cia}^{8}$, o fato de que a maneira pela qual um corpo de jornalistas específico edita,

\footnotetext{
${ }^{8} \mathrm{Na}$ entrevista, Otávio Frias Filho afirma: "O jornal personalizado é uma outra modalidade de oferta e de consumo de informação que nós temos procurado acompanhar, com atenção e interesse. Pessoalmente, acredito que possa crescer, ter um nicho de mercado, mas sem deixar de ser uma modalidade marginal. Por dois motivos: primeiro porque de certo modo os leitores não têm tempo e sabem que os jornais têm um corpo treinado de especialistas que fazem esse trabalho muito bem, certamente melhor do que ele próprio, leitor, faria. E, segundo, pela lei do menor esforço, que governa toda atividade humana. Nesse sentido, embora respeite o interesse dessa eventual minoria, não acredito em grande futuro para esse tipo de jornalismo." Op. cit.
} 
hierarquiza, apresenta as notícias, também tem um valor. Quando estou lendo o New York Times, para usar o exemplo clássico, não estou só me informando e louvando os textos, as matérias do $N Y T$, mas estou também encontrando o aporte expresso na maneira pela qual aquele grupo de profissionais organizou ou selecionou, editou, fatos relevantes nas últimas 24 horas. Então, tenho a impressão de que um dos objetivos do jornalismo de qualidade nesse cenário competitivo em que a gente está vivendo é o fato de que o estilo, a maneira de encarar os fatos e de editá-los também é um ativo, é algo que tem valor.

Do ponto de vista da rentabilidade, esse patamar, esse número atual de leitores, esse perfil atual de leitores, e olhando também para a tendência, a mudança nessa posição, o jornal em geral e a Folha em particular se mantêm com saúde financeira e independência?

Sem dúvida que sim. Até porque a crise financeira do fim dos anos 90 , que teve conseqüências tão negativas para os jornais, especificamente, teve pelo menos uma conseqüência positiva, digamos, no longo prazo. Impôs uma disciplina de custos, de gastos, inédita, pelo menos no nosso ambiente brasileiro. Embora nós tenhamos cortado drasticamente despesas, num nível seguramente além do que acharíamos razoável, aprendemos a cortar, a administrar a escassez de recursos, a nos adaptar a essa situação, que tenho a impressão de que veio para ficar. Não acredito que nós vamos voltar àquele período - olhando com os olhos de hoje sou tentado até a dizer - de quase esbanjamento que tivemos nos anos 80 e 90. Eu me lembro, por exemplo, de que na Copa do Mundo da França, em 1998, a Folha mandou 32 pessoas. Hoje, a gente olha, e fala: é realmente uma loucura. Aprendemos a trabalhar com recursos mais escassos. E mercê dos cortes que foram realizados a partir do ano 2000, até o ano passado, por exemplo, no caso da Folha, estamos operando com margens de resultado no fim do ano (de 2005) da ordem de $16 \%$, 17\%. São números muito bons e também inéditos para nós. Nunca tivemos margens tão altas. Porque as receitas têm-se mantido mais ou menos estáveis, têm reposto a inflação e, com os cortes de despesas, a margem aumentou muito. Infelizmente, essa margem vai praticamente toda para pagar dívidas, juros. Está-se reinvestindo muito pouco. Isso vale para todos, e vale 
também para a Folha. Mas, em termos de margem, de saúde operacional, ela nunca esteve tão boa, paradoxalmente.

Existem coisas que são caprichos de dono ou de diretor de redação que é jornalista, que acha que determinadas coisas têm que ser feitas, independentemente da questão contábil. Por exemplo, a Folha investiu na circulação nacional e no Estado de São Paulo, imagino que por apostar na influência, no prestígio que isso representa.

Sim.

A Folha conseguiu lidar com sua dívida, com seus credores, sem fazer a mudança feita na gestão tanto do Estado quanto do Globo - o que eles chamam de profissionalização. Você acha que, por um motivo como esse, ou por algum outro motivo, a tendência é a de ter uma gestão que não seja feita necessariamente pelo dono, num primeiro estágio e, num segundo estágio, chegar até a situação americana, de abertura de capital, com uma S/A com ações na Bolsa, e aí ter que dar satisfação trimestral ao investidor, à Previ?, etc.?

Acho que a tendência histórica é essa. Qual o ritmo, quando isso vai acontecer no grupo de mídia $x, y$, ou z, é claro que eu não saberia prever, mas eu diria que o vetor sem dúvida é esse.

No caso da Folha, existe alguma discussão nesse sentido na família?

Não existe nada de muito concreto. Meu irmão (Luís Frias, presidente da Empresa Folha da Manhã S.A.) e eu estamos ainda bastante envolvidos na operação, cada um na sua área. Meu irmão tem sabido aproveitar muito as oportunidades de inovação empresarial. Temos um sistema sucessório mais simples, até pelo número muito menor de pessoas que estão na condição de herdeiros.

No caso da abertura de capital e exposição aos investidores, os caprichos do dono, os caprichos de jornalista, que são aqueles que fazem com que o jornal mantenha cadernos que não sejam necessariamente rentáveis, mas que lhe dão prestígio, que o dono, o jornalista, quer ver publicado, assim como viagens,

\footnotetext{
${ }^{9}$ Fundo de pensão do Banco do Brasil, maior fundo de pensão e maior investidor em ações no País.
} 
coberturas dispendiosas, ou uma circulação nacional, correm risco no longo prazo?

Acho que sim. Mas acho que aí é preciso separar o joio do trigo. Em toda a nossa cultura jornalística, da qual a gente proveio, na qual a gente ainda está imerso, sempre havia uma margem de desperdício. E sempre foi também uma cultura jornalística onde havia menos preocupação com as demandas reais do leitorado e uma enorme preocupação com a auto-imagem dos jornalistas, com tradições do próprio veículo, com uma visão mais conceitual do jornalismo. Acho que isso tudo está sendo corrigido e é bom que seja corrigido. O que eu acho que é o pulo do gato, ou separar o joio do trigo, é, de novo, uma política que não implique em 8 nem 80 , ou seja, que a gente reduza as margens de desperdício, de esbanjamento, etc., que a gente focalize mais as demandas reais do leitor, e para isso é preciso conhecê-las mais, estudá-las mais, e trazêlas mais para perto do cotidiano das redações. A gente sabe que a lei básica das redações é a da inércia. Você começa a ouvir uma fonte, quando vê, daqui a 16 meses, continua ouvindo aquela fonte. Você começa a pautar um assunto, vê que o assunto começa a se autopautar quase que magicamente. É preciso quebrar esses hábitos adquiridos e trazer a vida real do leitor mais para perto do dia-a-dia dos jornalistas. Mas acho que é preciso fazer isso tudo sem descaracterizar os jornais, sem transformá-los em objeto de uma ditadura do departamento de pesquisas, sem desfigurar a identidade dos jornais, sem que os jornais deixem de respeitar uma certa linha de continuidade da sua atuação ao longo do tempo. No caso de um jornal como o Estado, por exemplo, essa linha de continuidade é muito nítida, muito clara, muito coerente. Esse é um dos principais ativos do jornal. No caso da Folha, não temos uma linha de continuidade tão propriamente linear, mas a Folha tem também um repertório de tradições, de imagens que ela desperta no público leitor. Não devemos partir para um atendimento muito imediatista, muito de curto prazo, das demandas do leitor. Como estamos numa época em que os mercados têm uma preponderância muito grande em todos os sentidos, numa época em que as empresas estão muito atentas aos seus desempenhos econômicos, até porque precisam liquidar os seus passivos financeiros, numa época em que os bancos estão prestando muita atenção na mídia, e em que muitos profissionais 
egressos de outras empresas acabaram exercendo funções de comando em empresas jornalísticas, acho que existe um risco, sim, de as empresas olharem muito para o imediato. Esses executivos precisam fazer resultados agora, e hoje estão numa empresa de comunicação $x$, e amanhã sabem que vão estar noutra empresa, não têm o compromisso com essa linha de continuidade, com essa tradição. Então, acho também que é preciso tomar cuidado, para, com essa mudança, não jogar fora a criança junto com a água do banho. Se depender de muitos desses executivos, você vai ter até um desempenho interessante deste mesmo investimento no começo do ano que vem. Agora, o que você vai ser, como jornal, como empresa, daqui a três, cinco anos, para muitos deles é irrelevante, porque isso não é responsabilidade deles.

Outra lei básica das redações é a falta de compartilhamento. Eu tenho o número do telefone do fulano, e é meu. Eu entro em férias e o jornal perde aquele contato. As novas tecnologias, e a nova mentalidade de comunicação que a internet introduz criam um pensamento em rede, as pessoas trabalhando juntas. E aí de novo a questão do protagonismo do jornalista. Por um lado, não seria interessante investir mais em bancos de dados, num lugar onde cada repórter pudesse colocar: 'às terças-feiras à noite, o prefeito joga baralho na casa tal da rua tal', uma coisa que ele descobriu com dificuldade, e cada vez que alguém tenha que falar com o prefeito na terça-feira à noite, vai ter que suar para chegar a essa informação? Por outro lado, uma forma de apuração, de fazer reportagem, na qual o indivíduo, a personalidade do jornalista seja menos importante, e mais importante o trabalho em rede, como numa agência de notícias?

Acho que, se as coisas fossem dessa maneira, seria melhor para os veículos. Agora, isso é muito da natureza humana. Há um elemento de competição interpessoal em todo ambiente de trabalho, e também nas redações, que, se for mantido dentro de limites moderados, é até saudável. E até também uma dose de vaidade, que a gente sabe que toda profissão tem, e a nossa tem bastante. Agora, acredito que as ferramentas tecnológicas e a própria pressão por sinergia, para voltar ao eufemismo, acabam forçando a comportamentos um pouco mais compartilhados. Mas não acho que vá haver nenhuma 
revolução por aí. Já acreditei e não acredito mais em revolução na natureza humana.

Vamos ter outros Euclides da Cunha, então?

Pois é, já imaginou? 


\section{Rodolfo Fernandes}

Diretor de Redação e diretor-responsável de O Globo. Concedida no dia 14 de novembro de 2005.

De 2000 para cá, houve uma queda de circulação dos três grandes jornais. Neste ano (2005), está havendo uma recuperação?

Estabilizou-se num nível bem inferior ao de anos atrás. Mas talvez fosse irreal a circulação de anos atrás. Coisa de 1 milhão, aquilo era turbinado de tal maneira que acho não era o público essencial dos jornais.

Tem a ver com os anabolizantes?

Tinha muito anabolizante.

OGlobo também os usou?

O Globo também. Teve muita coisa legal: literatura brasileira, enciclopédia... Acho que até teve uma função. Ninguém estava vendendo panela. Estava, de alguma forma, casado até com a função dos jornais. Mas aquilo serviu durante um período. Talvez tenha sido um momento de recuperação de renda muito rápida também. Uma série de fatores contribuiu para aquele patamar, que, na verdade, acho que era irreal. Eu sinto que os jornais estão se estabilizando num outro patamar. Acho que jornal não vai ser mais mídia de massa. A gente pode discutir se o jornal vai existir ou não. Mas uma coisa é certa: mídia de massa não será mais. Acho que o jornal cada vez mais vai cumprir um papel relevante, influente. Os jornais estão cada vez mais influentes, até porque 0 País vem numa onda de profissionalização da imprensa, depois da ditadura. Estamos num momento em que sou totalmente oposto às pessoas que dizem que os jornais eram bons 30 anos atrás. Tem uma maré saudosista aí. Acho justamente o contrário. Os jornais, hoje, são muito melhores, muito mais bem feitos, as pessoas são muito mais preparadas, a média das redações é muito mais preparada que há 30 anos. Hoje, isso é uma profissão, uma coisa que há 30 anos era bico. Acho que os jornais são mais independentes, as empresas são mais independentes. Nesse sentido, os jornais estão numa fase única na história da imprensa brasileira. Você falar de perda de relevância da mídia impressa, dos jornais e revistas, num momento como esse, acho totalmente descabido. Agora, se você se pergunta o que vai acontecer daqui a 20 anos, 
com a internet, com essa revolução toda, também tem que lembrar que há 10 anos tinha gente dizendo que nos 10 anos seguintes os jornais não existiriam mais. É uma profecia não realizada.

Você acha que esse jornal com uma circulação estabilizada para o público leitor de jornal, ele deixa de contar para esse leitor o que aconteceu ontem e passa a ser mais analítico?

Já é, um pouco. Acho que nunca vai deixar de ser - até pela origem do nome "jornal", ou seja, conta as coisas do "jour", do dia -, mas cada vez mais contextualizadas, cada vez mais partindo de um fato, para amarrar com outros assuntos existentes. Por exemplo, a entrevista do Lula (ao programa Roda Viva, da TV Cultura, que foi ao ar em 7/11/2005): o Jornal Nacional, no dia seguinte, mostrou os principais trechos. Mas só nos jornais é que se pôde ver as contradições do Lula, o que ele falou, as opiniões. Se a TV Globo fizer o que o jornal $O$ Globo fez no dia seguinte, derruba o Lula, porque a gente pegou todas as contradições dele. Até o cupim do Museu do Ipiranga que ele disse que as pessoas estavam reclamando que isso nunca tinha tido lá. Se a televisão fizer isso, com o tamanho que ela tem, derruba o presidente da República.

E a revista, rouba leitor do jornal, com as pessoas tendo menos tempo, preferindo pegar um resumo da semana, não se sentindo obrigadas a ler jornal todo dia?

Acho que as revistas e os jornais têm convivido pacificamente, digamos assim, ao longo das décadas. Não vejo um concorrendo muito com o outro. Acho que cada um tem o seu espaço. É certo que os jornais estão cada vez mais 'revistizados'. Se você pegar as edições de domingo do Globo, do Estado ou da Folha e botar no formato da Veja, elas são muito melhores do que a Veja. Os jornais aprenderam a fazer revista. São matérias investigativas, que levam uma semana, 15 dias, até 6 meses, coisa que as revistas não fazem mais. Acho que nessa disputa de jornal e revista quem tem que se reinventar é a revista, porque os jornais aprenderam o segredo da revista. As edições dominicais são revistas: têm matérias, bossas, entrevistas muito melhores do que as das próprias revistas. As revistas estão meio em xeque, na verdade. Nesse episódio de suspeitas, de escândalos (de corrupção no governo Lula), a 
Veja teve até um papel relevante. Mas, nos meses anteriores, a Veja estava totalmente desposicionada em relação à relevância das revistas.

Com matérias sobre dietas, o culto do corpo...

É a fórmula que as revistas encontraram para vender mais, porque é o que o público está querendo. Mas, com isso, elas perderam relevância política e deixaram os jornais entrarem por esse caminho nas edições dominicais.

O jornal que você dirige é o que está mais bem acompanhado em termos de meios poderosos, principalmente a televisão. Existe uma sinergia, para um impulsionar a venda do outro, alavancar a leitura do outro?

Não. Eu diria que a nossa sinergia com a TV Globo é zero. Talvez exista até uma certa competição velada. Até porque, são produções diferentes. Não tem condição de você acompanhar uma produção de televisão e fazer a mesma coisa num jornal. Nunca existiu uma sinergia entre TV e Globo. São direções totalmente separadas. A gente não sabe o que eles estão fazendo, e viceversa.

\section{E não há nenhuma discussão para se aproximar?}

Não. Já vimos até apresentações sobre "a mídia no futuro", o repórter (de jornal) sai com televisão, e tal.

Com a mochila cheia de equipamentos...

Mas são situações totalmente diferentes. Não vejo como a televisão vá abrigar uma matéria feita por repórter (de jornal). A missão para a qual eles estão direcionados está cada vez mais distante. Na medida que a gente entende que o jornal é cada vez mais um espaço de contextualização da notícia, de opinião, acho que isso o afasta da televisão. Embora a televisão esteja buscando comentarista de jornal, pessoas que passaram por jornal estão tendo mais possibilidades na televisão. A televisão está quebrando um pouco aquela ditadura, que existia pelo menos no Brasil, do apresentador bonitinho, para procurar mais jornalistas.

Principalmente a TV por assinatura, não é? 
Isso. Então, tem vários colunistas do Globo que são comentaristas da Globonews. Como a Folha fez com o SBT, por exemplo. Então, acho que esse é um caminho. Sinergia de produção nunca aconteceu.

E entre a internet e o jornal O Globo?

A internet é uma operação nova. Está todo mundo ainda tentando descobrir o que é o jornalismo na internet. Eu achava, lá no início, como a internet não tem problema de custo de papel, que a internet ia por um caminho de aprofundar o noticiário, de fazer textos mais longos. Mas ela naturalmente se revelou uma mídia concorrente do rádio e da televisão muito fortemente, porque é o noticiário em tempo real, ao longo do dia. Os jornais na internet não têm uma manchete. Eles têm 20 manchetes ao longo do dia. Acho que isso ainda deixa o jornal como aquele veículo onde você vai entender o que aconteceu. Eu não acho que a internet cumpre esse papel. Os jornais online foram pelo caminho da notícia curta, rápida, ligeira e sem profundidade. Embora você possa escrever na internet indefinidamente. Mas acho que pelo perfil do público leitor da internet, pelo menos ainda no Brasil, muitas lêem no trabalho, mais do que em casa. Quando chega 5, 6 horas da tarde, desaba a audiência dos jornais online. Então, acho que eles precisam competir rapidamente e muito ferozmente pela atenção do leitor. Por isso é que não consigo ver o fim do jornal, porque acho que o que o jornal faz não tem nenhuma outra mídia fazendo e não vejo a internet nesse caminho. A gente apura, está com 500 assuntos durante o dia, depois a gente vai refinando isso, nas nossas reuniões de editores às 5 da tarde, isso já passa para 100 assuntos, depois a gente bota 10 na primeira página, dizendo: essa é a manchete, esse é o assunto mais importante, essa é a foto mais importante do dia, esses são os temas que nós entendemos que são os mais relevantes para você, leitor. Então, é um noticiário dirigido, realmente. Se você não gostar da seleção que nós, do Globo, fazemos, você tem a opção de ler a da Folha ou a do Dia, ou a do Estadão. Mas, basicamente, o que a gente faz é isso: peneirar o noticiário, contextualizá-lo, acrescentar ou a opinião do jornal ou o enfoque editorial que a redação vai dar. E partir daí, você dá ao leitor o seguinte: entenda o que aconteceu no mundo. Então, você não vê na internet, por exemplo - não sei isso vai acontecer um dia em que tiver condições econômicas para isso - 
explodiu um conflito urbano em Paris. O Globo está lá com correspondente na Bélgica, na Inglaterra, na Alemanha, na Espanha, então você tem condições de fazer no domingo um panorama gigantesco do que está acontecendo na Europa (refere-se a um conjunto de reportagens publicadas na véspera, 13/11/2005, no Globo, sobre as tensões sociais nesses países). Quando você vai ver isso na internet? Amarrado para o leitor, bonitinho, chega lá na sua casa, com as informações relevantes para entender o que está acontecendo. Onde você vai ver a entrevista da Dilma Rousseff (ministra-chefe da Casa Civil) causando um marco na relação da política econômica dentro do governo? Foi num jornal, no Estadão. São fatos que estão sendo produzidos pelos jornais. Você vai dizer: daqui a dez anos pode ser diferente. Acredito que sim, mas acho que enquanto o presidente da República começar o dia dele lendo os jornais, e assim os empresários, os formadores de opinião, os intelectuais do País...

Os pauteiros de televisão...

Os pauteiros de televisão, de rádio. Você vê telejornais que são cópias de jornais da véspera. Se o jornal envelheceu, a televisão mais ainda, porque ela dá, às vezes, um ou dois dias depois notícias que os jornais já deram dias antes. Então, tenho muita dificuldade de ver a perda de relevância do que o jornal faz. Agora, evidentemente a gente sente que tem um público jovem entrando aí que não se acostumou a ler jornal, que a gente não sabe o que eles vão fazer quando começarem a trabalhar e precisarem da informação. Porque, em última análise, as pessoas lêem jornal porque precisam da informação, aquilo é relevante no contexto social delas. Quando meu filho de 15 anos de idade, ou o pessoal que está com 20 anos de idade hoje, entrar no mercado de trabalho, precisar desse tipo de informação, onde eles vão buscar? Eu me surpreendo com meu filho de 17 anos de idade, que às vezes chega em casa e já sabe de um monte de coisa. Ele leu aí, vasculhando aí na internet. Talvez ele não tenha a visão geral de um tema que hoje só o jornal realmente pode proporcionar.

Nas pesquisas que vocês fazem, vocês sentem essa divisão geracional: os mais velhos com mais aceitação do meio jornal do que os mais jovens? 
É, isso a gente sente muito claro no público mais jovem. O problema é que a gente não sabe se é porque ele é jovem - e a gente cairia naquela coisa do Nelson Rodrigues: "Jovens, envelheçam" - e seria uma questão de esperar eles envelheceram, ou se é porque eles estão bombardeados por outras informações. Eu acho que não é mais porque eles são jovens, vão envelhecer e vão ler jornal. Eu acho que, hoje, o fenômeno digital é uma coisa avassaladora. Daqui a pouco vai ser no celular. Onde isso vai dar, a gente não sabe. Mas, que a internet já mudou o jornal, é um fato. Hoje, quando você trabalha um assunto, ao longo do dia, você mesmo, que está lidando com a notícia, já foi bombardeado com várias informações sobre o mesmo tema. $O$ noticiário é quase uma suíte. Mesmo as revistas, muitas vezes, estão repercutindo antes de irem à banca. A Veja dá furo eventualmente no online. Quando vai para as bancas, já influenciou o noticiário.

No caso do Severino Cavalcanti, presidente da Câmara acusado de receber propina de dono de restaurante), durante a semana eles mostraram 0 documento que comprovava a matéria publicada na semana anterior. Não podiam esperar.

Isso. Quer dizer: o jornalismo online já influenciou e já mudou o jornalismo impresso. Eu acho é que ele não fez ainda o jornalismo impresso perder sua relevância. E não tenho condição de prever se isso vai acontecer no futuro. Mas não acho que o jornalismo online esteja indo nesse caminho, de fazer o que o jornal faz. Eu não vejo ninguém fazendo o que hoje os jornais fazem. Não sei se no futuro vai ter alguém que proporcione isso.

Por um lado, o leitor mais velho tem mais poder aquisitivo e dá mais retorno publicitário. Por outro lado, o leitor jovem é quem no futuro vai ser o consumidor. OGlobo tem tentado cooptar o jovem?

Acho que hoje o grande desafio em qualquer lugar do mundo aonde você vai, onde tem cinco jornalistas discutindo o futuro empresarial desse negócio, estão pensando como atrair o jovem. A gente já esteve em vários locais do mundo, com vários jornais, todos no mesmo dilema, cada um tentando fazer uma coisa diferente. Fazem suplementos, lançam tablóides gratuitos, acho que tudo em vão. Na verdade, não tem nenhum exemplo de sucesso de coisa que esteja sendo feita em jornal, que você possa dizer: esse é o caminho, está dando 
certo, para capturar a atenção do jovem. Nada deu certo. A gente viu uma pesquisa completíssima que o Times fez em Londres, sobre os desejos e o perfil do jovem, mas daí a se conseguir transformar isso num produto que atraia a atenção do jovem, ninguém ainda conseguiu.

O gasto com papel, tinta e distribuição no Estado representam cerca de $35 \%$ e na Folha, 40\%. No Globo também estão nesse patamar?

Por algumas características de mercado do Rio e de São Paulo, aqui é um pouquinho mais barato. O peso disso é um pouco menor, especialmente o da distribuição. São Paulo tem um interior grande, coisa que o Rio não tem. $A$ Folha e o Estado entregam o jornal em todas as bancas. Aqui tem um sistema de capatazias. Os jornais do Rio entregam para algumas poucas dezenas de representantes, que distribuem os jornais nas suas bancas. São os chamados capatazes. Eles são donos de conjuntos de bancas, e eles fazem essa distribuição.

\section{No interior também?}

Não, no interior, a gente faz, mas o interior do Rio são poucos municípios. A Folha tem uma operação especialmente cara porque a diferença que a Folha tem para ser o maior jornal do País, ela tira fora de São Paulo. A Folha vende menos em São Paulo do que o Globo vende no Rio. O que é curioso, porque o mercado de São Paulo é muito maior que o do Rio. A penetração em São Paulo é tradicionalmente menor que no Rio.

Mas o Globo tem uma boa distribuição, não tem?

Mais ou menos. A gente tem problemas, às vezes, em Brasília. Tem muita gente em São Paulo que diz que não acha o Globo, quando você acha a Folha no Rio com muita facilidade, porque ela vez de caminhão muito cedo. Se você chegar à Lagoa da Conceição, em Florianópolis, às 7 horas da manhã, tem a Folha lá. Você vai num engarrafamento, em Curitiba, tem alguém vendendo a Folha. Mas isso tem um custo pesadíssimo para eles.

Essa diferença é clara entre o Estado e a Folha. O Estado olhou na planilha de contabilidade. A Folha teve uma decisão estratégica, de prestígio, de influência. OGlobo está no meio do caminho entre os dois? 
O Globo tem como sua definição estratégica ser um jornal da classe média do Rio de Janeiro, com prestígio e repercussão nacional. Isso foi deliberado alguns anos atrás. E não faz loucura para isso. Não vejo o Globo apontando na direção dessa operação que a Folha tem, por exemplo.

Vocês estão sem concorrente?

Sim, isso, para mim, em termos editoriais, aqui para a redação, é a principal dificuldade hoje do Globo. É claro que, em termos empresariais, teoricamente, é melhor não ter concorrente. Mas acho que, em termos de estímulo profissional, um concorrente faz muita falta. Então, acho que nosso principal desafio, aqui, é concorrer com a gente mesmo. A gente concorre, em termos nacionais, obviamente com a Folha e com o Estado, mas que são jornais diferentes. O perfil de jornal do Rio, por algumas características, é diferente do perfil de jornal de São Paulo. O paulista é um pouco mais contido, os jornais não se permitem certas doses de emoção. As manchetes da Folha são muito centradas no fato especificamente. A Folha repete exatamente o que foi a escalada do Jornal Nacional. Ela não interpreta o fato, não avança, não faz um título um pouco mais revistizado e interpretado. O Estado era assim, mas sinto que o Estado tem mudado bastante nos últimos tempos.

Agora, o Globo é um pouco mais local, um pouco mais voltado para o Rio de Janeiro?

$E$ É, os jornais do Rio, tradicionalmente - $O J B$, quando era influente, também era assim - têm uma relação com a cidade diferente dos jornais de São Paulo. É da tradição da cidade do Rio de Janeiro uma forte cobertura local. Você raramente vai ver uma manchete de Cidade na Folha ou no Estado. É muito difícil. E no Globo é muito freqüente. Você pode achar que é porque o Rio foi capital do País, então os temas do Rio são nacionais. Teve um caso recente que achei fantástico. Descobriram a febra maculosa em Itaipava, no Estado do Rio. Foi chamada na primeira página do Globo, naturalmente, mas foi chamada de primeira página na Folha. Este ano, já morreram quase 50 pessoas do mesmo problema em São Paulo. E isso não mereceu a atenção da Folha de São Paulo. Só quando aconteceu no Rio de Janeiro. Então, a quantidade de notícias que a Folha, por exemplo, dá do Rio de Janeiro é maior do que ela dá de São Paulo. O Rio tem essa característica de ser uma cidade nacional. Por 
outro lado, acho que o carioca tem uma natureza de relacionamento com a sua cidade diferente da do paulista. O paulista não ama São Paulo nesse sentido. O carioca, não. Se vai derrubar uma casa não sei onde, isso chama a atenção dos jornais. Se vai mudar o zoneamento da Zona Sul, para criar apart-hotéis, isso foi um tema, uma discussão enorme, que decidiu uma eleição no Rio de Janeiro. A eleição do César Maia contra o Conde foi decidida pela exposição que o Globo fez da questão da lei dos apart-hotéis. Queriam fazer que nem fizeram em São Paulo: dois prédios com uma garagem e apartamentos pequenos. A questão das favelas mobiliza a cidade, vira tema de discussão muito forte. Então, o Globo, com muita freqüência, tem manchete de assuntos locais.

Você falou em campanhas, eu me lembrei do jornalismo cívico. Em São Paulo, a Folha e o Estado não costumam entrar em campanhas. Recentemente, 0 Globo fez uma campanha sobre cocô de cachorro na rua...

Pitibull, cocô de cachorro... Isso acho que vem de uma necessidade que o leitor do Rio tem de defender a sua cidade. A coisa do pitibull foi muito forte. Recebíamos muitas cartas. Então isso vai te empurrando para um tipo de jornalismo que talvez possa até se chamar de cívico, ou comunitário. A seção de cartas do Globo tem debates, um leitor fala, outro responde, daí entra uma autoridade, e os caras esculhambam. Então, tem um ambiente de debate de assuntos da cidade muito forte.

Como está a profissionalização da gestão nas Organizações Globo?

Aqui, há pelo menos dez anos, os acionistas decidiram sair da gestão diária dos negócios e transferiram isso para profissionais. No Globo, isso foi muito visível. Se não me engano a partir de 1995, eles organizaram um Conselho Editorial, do qual participam representantes de todos os veículos, onde se faz uma discussão de temas, as pessoas fazem apresentações, os assuntos são debatidos, mas não tem uma ação de gestão no dia-a-dia dos negócios, incluindo a área editorial. Assim como eles profissionalizaram a gestão, o Globo tem um diretor-geral que não é da família. Ao contrário da Folha, onde tanto a direção geral quanto a direção de redação estão nas mãos dos próprios acionistas. Hoje, seria inimaginável, aqui, você fazer uma reunião de editores com o dono: quem vai decidir a manchete do jornal é o dono do jornal. Foi feita 
uma coisa muito profissional. O (editor de Opinião, Aluizio) Maranhão discute diretamente com o João Roberto Marinho os editoriais e a redação circula em cima dos próprios acontecimentos, não tem ação e interferência diária nos negócios do dia-a-dia.

Quais são os cargos de direção que a família Marinho tem?

Como são três irmãos, eles dividiram em três áreas diferentes de atuação. $\mathrm{O}$ Roberto Irineu Marinho ficou com a parte de gestão, ele é o presidente da Globopar. O José Roberto Marinho ficou com a parte de representação e relacionamento com a sociedade, com o terceiro setor. E o João Roberto Marinho coordena a parte editorial, questões relativas a conteúdo e também de relacionamento externo.

Estamos no meio do caminho. Se você olhar para o processo americano, lá os jornais viraram empresas de capital aberto, com ações na Bolsa. E quando você tem o dono jornalista, ou gestores profissionais jornalistas, eles cometem caprichos de jornalistas, fazem coisas que não são rentáveis, cadernos que eles querem ler no seu jornal, não porque vendam anúncios; ou distribuir bem em Brasília porque você quer manter o prestígio, a influência. Você pensa que, nesses dois estágios, a situação é mais ou menos a mesma: o dono jornalista com tinta nas veias que estava no dia-a-dia, e você hoje um jornalista de carreira que também tem as suas decisões que são statements de um jornalista? Você sente perigo de, no futuro, com uma abertura de capital, esses caprichos de jornalistas se tornarem inviáveis?

Acho que a gente caminha para isso, em algum momento, não sei quando. É uma tendência mundial. Na medida em que você precisar fazer mais investimentos, quando tiver que buscar esses recursos, um caminho mais barato talvez seja abrir capital e buscar um sócio capitalista. Isso é uma dificuldade do tipo de sócio que você vai ter, de compreensão de que, no jornal, as coisas não são isoladamente rentáveis. O jornal é um conjunto de coisas. Não acredito que nenhum jornal brasileiro tenha um caderno literário rentável. Pelo contrário. Jornalismo é uma operação cara. Correspondente no exterior é uma operação cara. Ter um correspondente em Pequim é uma operação complicada. Manter uma sucursal em Brasília é uma operação caríssima. Ou a pessoa tem a compreensão de que jornalismo de qualidade é caro, mas dá 
retorno, se não todo mundo faria jornal popular, que é barato de fazer, mas não dá retorno. A margem de lucratividade que os jornais populares dão é muito pequena. Por outro lado, o Globo, Folha e Estado são negócios muito lucrativos, se bem administrados. Até este mês - eu estava participando de uma reunião de manhã - é o maior faturamento da história do Globo, e deve ter sido da Folha e do Estado também. O mercado publicitário ainda reconhece nos jornais esse conjunto de fatores relevantes. Então, na medida em que você vá ter um sócio que vá querer baixar a qualidade do veículo, isso vai acabar sendo um tiro no próprio pé. Se os jornais forem por esse caminho, vão automaticamente se tornar menos relevantes, porque o seu diferencial é justamente o que você tem: é sua sucursal em Brasília, são os seus colunistas, que são caros, são os seus correspondentes, são as viagens que você pode fazer. Então, teve um tsunami na Ásia, no dia seguinte você está lá na região. Isso tudo é muito caro. Acompanhar a seleção brasileira nos Emirados Árabes Unidos... Tudo é caro no jornal. Mas é isso que faz o jornal esse veículo tão importante, tão relevante e tão reconhecido pelo mercado publicitário.

Você já falou do jornalista que produz para todos os meios. Pelo que entendi, é uma coisa que não está em perspectiva aqui para vocês, uma integração...

Com a televisão, não. Eu separaria a televisão. Mas o resto é inevitável. A fusão da operação do jornalismo impresso com o online é uma questão de tempo. Digamos que é uma questão mais física - de você conseguir colocar todo mundo junto - do que propriamente de conceito.

Eles (redação online) estão neste prédio?

Estão neste prédio, só que em outro andar. A gente está começando a preparar as preliminares para essa fusão, que a gente precisa ir para um outro andar, fazer uma obra muito grande. Mas a operação já é conjunta. Hoje, o repórter já sabe que, quando sai de uma entrevista, o mais rapidamente possível, deve botar isso no online. O conceito de furo já mudou. A declaração você já não tem necessidade de guardar para o dia seguinte. Você vai, depois, é tentar pegar um bastidor, uma outra informação que não esteja na internet. Quanto a isso, acho que a coisa foi indo de tal maneira, chegou um momento que pensamos: já estamos juntos, já somos uma operação só. É só botar um ao lado do outro. E aí criar uma forma de relacionamento, o que vai para o 
online, o que vai para o impresso, enfim, aí há mecanismos de edição que a gente vai ter que trabalhar melhor. Mas, objetivamente, já estamos trabalhando juntos.

Você disse que o jornal vai continuar sendo um pouco factual, porque ele é um veículo diário e é uma característica dele. Por outro lado, você acha que vai haver mais preocupação de agregar valor, torná-lo um pouco mais analítico, um pouco mais contextualizador?

Com certeza.

Para isso, você vai precisar de profissionais mais qualificados?

Quando o Globo fez a reforma gráfica, em 1995, ela já foi por esse caminho. Então, quando vejo a Folha dizendo que vai fazer uma reforma gráfica, mudanças para adaptar o jornal a essa linha, eu digo: bom, isso já foi feito dez anos atrás. ${ }^{10}$ A Folha foi pelo caminho oposto. A Folha foi para o modelo do USA Today, de notícias curtas, muita informação ao mesmo tempo. Acho que esse modelo está em xeque. Não é mais o modelo que serve para jornal. $O$ USA Today foi comido pela internet mais rapidamente do que o outro sistema. O projeto da Folha foi revolucionário em determinado momento. Mas acho que ficou velho mais rapidamente do que os outros. Acho que a reforma que o Estadão fez (em 2004) aponta também nesse caminho no sentido em que o Globo pretende ir: de matérias maiores, mais analíticas, com enfoques mais precisos.

A impressão que a gente tem é que o Globo fala assim: hoje vamos investir nesse assunto.

Isso. E o Globo era justamente o contrário, era aquele jornal que achava que tinha que dar tudo. Hoje, é impossível: você não tem mais gente, não tem mais espaço físico para isso, então tem que fazer apostas. O projeto gráfico do Globo é assim. A gente até sofre muito com isso aqui. Tem dias que a gente só pode botar uma foto na primeira página. É um drama que a gente passa. Mas é o seguinte: nós vamos dizer para o leitor o que nós achamos de mais importante no dia foi isso aqui. Então, tem uma manchete, tem uma foto e uma hierarquia muito clara de noticiário. Essa foi uma discussão muito forte lá em

${ }^{10}$ A Folha passou a ser publicada com o novo padrão gráfico a partir de 21/5/2006. 
1995. Não era ainda a internet, mas já era a televisão. A gente dizia assim: não tem sentido o jornal repetir a manchete da elevisão no dia seguinte. Pelas pesquisas, $80 \%$ dos leitores do Globo vêem Jornal Nacional. Não tem sentido repetir o que ele já viu no Jornal Nacional. Isso se aprofundou com a internet, radicalizou esse caminho, porque mais pessoas já viram mais notícias ao longo do dia, então cada vez mais você tem que tentar ter um enfoque exclusivo. Não falo nem do furo, que é o básico de qualquer atividade jornalística, seja televisão, rádio, internet. O furo sempre vai continuar sendo o furo. Mas, como você não tem um furo todo dia, você tem um enfoque diferente, tem uma forma de dar aquela notícia, você ouve mais gente, você tira partido do que o jornal pode fazer de diferente, que é repecutir. A televisão não tem condição de repercutir todos os assuntos todos os dias. Eles também têm um limite. $A$ internet, também. No dia da entrevista do Lula, foi interessante, porque a entrevista começou a repercutir antes de ir ao $\operatorname{ar}^{11}$. Você vê a velocidade da notícia. A internet começou a antecipar o que o Lula diria. Aí veio a entrevista, o Jornal da Globo logo em seguida fez um apanhado da entrevista, e o Jornal Nacional do dia seguinte pegou os melhores momentos da entrevista. Mas onde você foi ver a opinião sobre a entrevista, o que o Lula tinha falado, o que estava certo, o que estava errado, os dados? O Lula falou de economia. Está certo? O Primeiro Emprego está indo bem, como ele falou? Não. Você só viu nos jornais. Então, quem quis se informar e formar sua opinião sobre o que o Lula tinha dito teve que ler nos jornais.

Quantos jornalistas tem o Globo?

Em torno de 340, contando correspondentes, sucursais...

Já teve muito mais que isso?

Com certeza. Já teve 600 jornalistas aqui.

Vocês tinham muitas sucursais?

Tínhamos uma sucursal grande em São Paulo. Hoje é uma sucursal pequena.

É junto com o Diário de São Paulo?

\footnotetext{
${ }^{11}$ A entrevista foi gravada na manhã de 7/11/2005, no Palácio do Planalto. Ao sair da gravação, os entrevistadores passaram informações sobre seu teor para os repórteres. Às $20 \mathrm{~h}$, antes de ir ao ar, a TV Cultura fez uma apresentação para jornalistas, para que os jornais pudessem publicar trechos já na edição do dia seguinte.
} 
Não, é no mesmo prédio. A sucursal do Globo faz o que não é o dia-a-dia, que o Diário de São Paulo faz. Se tiver uma coletiva na Prefeitura de São Paulo, o Diário de São Paulo vai fazer. Mas, se for para apurar um bastidor sobre a briga Marta-Serra, e se isso for uma prioridade do Globo, aí os repórteres do Globo fazem.

Você tem, no seu computador, acesso a todo o material do Diário de São Paulo?

Tenho. E temos a sucursal de Brasília, onde não fechamos vagas, pelo contrário, abrimos, nos últimos dois anos. E temos correspondentes no País. Mas já teve sucursal no Recife, Porto Alegre, Salvador... Hoje tem uma pessoa em cada lugar. Nesse ponto, a estrutura de cobertura do País sofreu muito. Mas, você também não tem espaço para publicar tanta matéria. Como o bolo de jornais diminuiu, não tem sentido ter uma operação que você não vai botar no jornal.

Você acha que vai continuar diminuindo o tamanho do jornal?

Acho que chegou ao mínimo aqui. Por outro lado, você sente que às vezes o jornal é grande demais para quem está lendo. A pessoa não tem condição de ler tudo. Mas eu acho que o leitor do jornal não é leitor de tudo. Tem o que quer ler Economia, que quer ler uma boa Economia. O que quer ler Esporte, quer ler um bom Esporte. O que quer ler Política, quer ler uma boa Política. Então, como fazer um jornal menor, sem transformar uma dessas partes numa coisa tão rasa que não vai interessar ao leitor identificado com aquele assunto? Se você diminuir mais o Esporte, aquilo é uma porta de entrada do jovem, então o jovem não vai mais ler jornal. Se você diminuir Economia, as pessoas que são influentes na economia, os economistas, os empresários vão deixar de ler. Se você diminuir a Política, aquilo é o maior fator de influência do jornal. É um cobertor curto.

Há alguma discussão sobre formato, tablóide, etc.?

Não para o Globo. Sinto que as pessoas que lidam mais com jornal popular estão estudando o assunto, estão atentas a tudo o que está acontecendo no mundo. Mas não para um veículo como o Globo. 
O Extra (jornal popular das Organizações Globo) é um sucesso, não? Nesses anos, ultrapassou a circulação do Estado.

Da Folha, também. O Extra chegou, em alguns momentos do ano (2005), a ser o jornal mais vendido do País. Mas é o modelo do jomal popular, com preço barato e anabolizante. Dá para sentir que tem um público por baixo dos jornais populares - você vê agora aparecendo operações em vários pontos do país -, jornais muito baratos que estão funcionando. Aqui, foi lançado o Meia Hora (para ler em meia hora), a $R \$ 0,25$, em Belo Horizonte também foi lançado um jornal a esse preço, e ambos estão vendendo muito bem. Não tem anúncio, ainda. É uma operação complicada, porque você sente que tem um leitor disposto a pagar pouco para ter a notícia, uma informação rápida. Mas, como rentabilizar esse negócio, é uma coisa complicada. Fomos visitar um jornal gratuito na Espanha chamado 20 Minutos. Ele já está com a circulação igual à do El País, e com muitos anunciantes, tipo El Corte Inglés (loja de departamentos). Eles só não circulam mais do que El País porque não querem, porque quanto mais exemplares, o custo aumenta. A equação de quantos jornais populares você vai colocar na rua é vital. Mas tem um público que surge abaixo do jornal popular no Brasil, um público que gostaria de pagar menos ainda e estaria disposto a ter uma informação mais rápida ainda do que os jornais populares dão. Acho que esse é um fenômeno que vai surgir forte nos próximos tempos desse mercado. 


\section{Ramón Salaverría}

Diretor do Media Lab da Faculdade de Comunicação da Universidade de Navarra, em Pamplona (Espanha). Concedida em dezembro de 2004.

O que vai acontecer com o jornal de papel?

Isso deveria importar relativamente pouco para as empresas de comunicação. A questão é muito importante para o segmento do papel e celulose, para quem o mercado dos jornais é prioritário. O mercado das empresas informativas não é o mercado do papel, é o mercado da informação.

Mas quando se vai para on-line, não muda muita coisa?

Estamos vivendo um processo de mudança nas audiências. Os jovens não estão acostumados a ler jornais de papel. Isso não significa que não estejam acostumados ou interessados na informação. São coisas distintas.

Mas estão interessados em ler?

Eu diria que há diferentes ipos de jovens. Na Espanha, estamos detectando um certo tipo de jovem que está muito interessado em aspectos lúdicos, no ócio, mas que também tem interesses especializados, como a tecnologia, a música, aspectos que talvez não sejam a informação em geral, mas em torno dos quais se estão desenvolvendo cadeias de informação muito especializadas. Isso está criando um hábito de consumo de informação. Queremos pensar que, na medida em que esses jovens vão adquirindo certa maturidade, esses hábitos de informação não vão se limitar unicamente ao lúdico, mas abrangerão temas que afetam nossa sociedade.

Quando um meio se torna online, exige-se dele que seja interativo, que haja uma participação ativa dos leitores na formulação de conteúdo. Aí começam as mudanças para um veículo acostumado a assumir a responsabilidade sobre $o$ que publica?

Há uma dificuldade por parte dos meios de comunicação e dos jornalistas em particular em se acomodar a um novo entorno no qual as audiências têm a possibilidade não só de responder, mas de falar entre si a propósito do que nós Ihe informamos. Isso gera processos de movimento informativo que até agora não existiam ou que pelo menos não se tornavam públicos. $A$ forma de 
modernizar os meios de comunicação virá em boa medida condicionada pelo modo de interpretar a interatividade. Aspectos como a hipertextualidade ou a multimidialidade são linhas lingüísticas com as quais já se trabalha há bastante tempo. O jornal de papel, por exemplo, é um tipo de documento até certo ponto hipertextual, porque temos um texto principal que se conecta com outros textos, com fotos e gráficos. Do ponto de vista dos jornalistas, esse conceito já foi assumido. A multimidialidade - o fato de combinar sons com imagens $e$ eventualmente com textos - também tem sido desenvolvida pela televisão. Mas a interatividade, ou seja, incorporar o leitor ao discurso jornalístico, é algo radicalmente novo, e é a isso que os meios digitais estão conferindo um protagonismo. De certa maneira, esse impacto já está chegando aos meios impressos, ao rádio e à televisão. Os impressos já empregam sondagens com os leitores, abrem a possibilidade de os leitores proporem temas para debates, enfim, estamos assistindo aos primeiros passos, mas terminará mudando o discurso jornalístico que conhecemos há séculos.

Com o fim do jornalista como emissor único de informações e com essa participação 'caótica' de muita gente, como fica a questão da credibilidade e da responsabilidade sobre a veracidade da informação?

Os veículos de comunicação continuam sendo necessários. Há muita gente que proclama de maneira apocalíptica que os meios já não têm nenhuma missão na sociedade atual. Eles têm. E sua missão é a interpretação, hierarquização e seleção da informação realmente relevante.

Pode-se fazer isso na internet também?

$\mathrm{Na}$ internet estão nascendo publicações, fóruns, sistemas de informação que também fazem interpretação, seleção e hierarquização informativa, com modelos novos, em alguns casos de caráter democrático, como Slash Dot (www.slashdot.org) e Barra Punto (www.barrapunto.com). São fóruns nos quais indivíduos, de maneira anônima, participam desse processo informativo, elegem a informação que consideram de verdadeira qualidade e deixam de lado a informação que é simples ruído. E, como diz Dan Gilmour, sempre há um leitor que sabe mais que o jornalista. Esse leitor agora é potencialmente também um usuário e um emissor de informação. Portanto, essa pessoa que 
tem um alto conhecimento sobre o tema tem capacidade também de fornecer uma informação de alta qualidade. Essa é a grande novidade.

Depois do trauma da explosão da bolha (da internet), no início desta década, ainda está em questão a sustentabilidade econômica dos veículos on-line?

Uma das razões pelas quais as empresas de comunicação não deram ainda muita importância aos meios digitais, em comparação com a televisão ou o jornal de papel, é precisamente porque seu impacto econômico é muito reduzido, e porque só em muito poucos casos algumas empresas de comunicação têm conseguido ser rentáveis na internet. Na Espanha, por exemplo, hoje em dia temos só um jornal rentável na internet, que é a edição digital de El Mundo. Essa falta de rentabilidade faz com que o investimento por parte das empresas de comunicação seja também limitado. Isso gera um círculo vicioso, e uma dificuldade para que meios digitais se desenvolvam. Mas, olhando em perspectiva, acho que foi bom que a bolha especulativa que rodeou toda a internet tenha ocorrido e se tenha furado. Em 1998, os veículos da internet eram pura fumaça. A gente visitava um lugar e nos diziam: 'Isso está avaliado em tantos milhões de dólares.' Mas onde estava o respaldo disso? Eram as supostas expectativas. Agora chegamos ao ponto praticamente inverso. Agora que as audiências de internet já alcançaram níveis muito significativos em todo o mundo, temos muito mais usuários de internet do que há seis anos; agências de viagens estão vendendo passagens pela internet; algumas áreas comerciais estão tendo um desenvolvimento enorme. Curiosamente, agora que parece haver um desenvolvimento sólido das empresas de internet, são as empresas de comunicação que estão adotando uma estratégia especialmente defensiva. Para aumentar o pessoal na área digital, é preciso brigar dentro da empresa. E curiosamente, na Espanha, o meio digital que tem mais jornalistas é o único rentável.

Houve uma confusão por parte das empresas, ao investir em infra-estrutura de comunicação, para garantir o monopólio da distribuição, quando seu negócio era o conteúdo. Nessa nova etapa, as empresas terão de se manter focadas na informação, ou podem avançar para outros negócios que envolvem o segmento digital? 
A internet está se desenvolvendo de muitos pontos de vista, e um deles é o tecnológico. Nesta primeira década, a web esteve condicionada por uma limitação física: era preciso estar conectado a um computador para poder acessar a rede. Isso já não será mais assim. Agora, a internet vai se converter em um tipo de rede ambiental, que vai estar à nossa disposição através dos celulares. E a penetração dos celulares é muito mais democrática que a dos computadores. Na Espanha, $87 \%$ dos habitantes têm celular. Claro, os celulares têm vida útil de dois, três anos, quando muito. Agora, com a terceira geração da telefonia - um sistema no qual teremos não só voz e dados, mas conteúdo audiovisual em banda larga -, isso vai resultar numa revolução lingüística, porque poderemos acessar a informação de maneira direta, a todo momento. A informação de última hora nos vai chegar pelos celulares.

E o que vai acontecer com a publicidade? As empresas vão querer fazer anúncios nesses veículos ou os usuários vão sustentá-los pagando diretamente pelos serviços?

A publicidade foi outra das vítimas da bolha especulativa. Havia expectativas de retorno muito grande quando a internet começou. E a publicidade parou. Atualmente, ela está voltando aos meios digitais. Na Europa, as cifras de investimento publicitário nos sites de internet se multiplicaram. Empresas como Yahoo! e Google estão obtendo lucros muito altos graças precisamente a novos formatos de publicidade, como as palavras patrocinadas nos mecanismos de busca. O Google vende palavras-chave. Se o usuário faz uma busca com a palavra 'Brasil', por exemplo, pode aparecer o anúncio de uma agência de viagens que esteja promovendo pacotes para o país.

A convergência dos meios, como computador e televisão, já é vista como inevitável?

Estão ocorrendo simultaneamente um processo centrípeto e outro centrífugo. Centrípeto no sentido de que alguns elementos acumulam possibilidades tecnológicas que antes só eram possíveis em distintas ferramentas tecnológicas individuais. Agora, com uma única ferramenta, pode-se fazer muitas coisas. O computador, nesse sentido, está-se convertendo no núcleo estratégico de todos esses eletrodomésticos que funcionam na casa. Mas, por outro lado, há um modelo centrífugo, que faz com que todas as ferramentas, 
como os telefones celulares, acumulem também possibilidades que antes eram patrimônio do computador, os televisores acumulem possibilidades que antes eram patrimônio do rádio e assim por diante. Há um processo de intercâmbio, no qual, com qualquer ferramenta tecnológica, podemos fazer muito mais coisas do que antes. 


\section{Nicholas Negroponte}

Diretor do Media Lab do Massachusetts Institute of Technology (MIT), em Boston (EUA). Concedida em julho de 2005.

O capitalismo industrial está estruturado de forma vertical. A sociedade da informação em rede é horizontal. Que tipo de mudança isso representa?

Acho que uma das razões pelas quais se tem uma estrutura de cima para baixo em quase todas as situações sociais é que é a forma mais fácil de controle. Em cada ponto, você sabe exatamente quem é o responsável. A natureza não age dessa maneira. A natureza é uma rede. E há muitos processos correndo em paralelo. O que as redes de computadores estão fazendo é nos permitir, pela primeira vez, fazer as coisas de uma forma mais distributiva, na qual os elementos tenham um papel concorrente. Isso é muito possível, e estamos vendo cada vez mais. Surge a capacidade de ter sistemas altamente organizados sem nenhum controle central. A internet é um bom exemplo disso. Não há nenhuma autoridade central. Esse tipo de coisa está emergindo. A Wikipedia é um exemplo perfeito. Crianças terem acesso a um volume tão gigantesco de conteúdo é um fenômeno extraordinário.

Nesse contexto, o que acontecerá com os jornais e com o jornalismo?

São duas questões separadas. Em inglês, é muito interessante que a palavra 'jornal' (newspaper) inclua a palavra 'papel'. O que está morto é o papel, não a notícia. O fato de que ainda se faça em papel é meio intrigante, mas será descontinuado rapidamente. $O$ jornalismo não vai desaparecer. $O$ jornalismo vai aumentar. Surgirão formas diferentes de jornalismo, que já se vêem, como os bloggers. É um tipo de jornalismo. Também se verá o tipo de jornalismo da $\mathrm{CNN}$, feito de um ponto de vista global, porque tem editores fazendo-o. Mas os dois tipos conviverão - o de baixo para cima e o de cima para baixo. Há o guia de restaurantes Zagat (www.zagat.com), feito pelas pessoas que freqüentam os restaurantes. Elas votam. E há os guias escritos pelos especialistas. A questão não é que um seja melhor que o outro. Ambos devem existir. Um expert o fará de uma forma e a votação, de outra. Portanto, não é que um vá tomar o mercado do outro. São duas abordagens concorrentes de guias de restaurantes. 
Como fica a hierarquia, a escolha entre o que é mais importante e menos importante, entre o que é verdadeiro e o que não é? É a isso que chamamos jornalismo. $E$ isso vai sobreviver?

Sim, mas esse jornalismo se refere mais ao processo editorial. E acho que esse jornalismo de cima para baixo encontrará crescentemente o seu valor no ponto de vista. Com exceção de alguns poucos fatos, a maioria das matérias em um jornal é importante por causa do ponto de vista sobre o fato, não por causa do evento em si, quantas pessoas estiveram envolvidas, quantas pessoas morreram ou citações precisas. O que é importante é o ponto de vista da reportagem.

Porque os fatos em si os leitores já conhecem, por todo tipo de fonte de informação durante o dia...

E também porque eles podem não ser tão importantes. As implicações (é que são). Então, quando discuto com você o laptop, ${ }^{12}$ acho que a parte mais importante da matéria não são os detalhes sobre os materiais, ou se podemos fazê-lo por 100 dólares, mas o ponto de vista segundo o qual as crianças na verdade aprendem mais fora da escola do que dentro dela, e que queremos usar as crianças como agentes de mudança, ao levar o laptop para casa, onde seus pais podem até ser analfabetos, e podem aprender com as crianças, e 0 impacto que isso teria sobre a sociedade. Isso é um ponto de vista. $E$ acho que é o que importa. Um outro jornalista, de uma publicação especializada, poderia pegar exatamente o mesmo assunto e escrever sobre como a proposta afetaria a indústria de monitores de computadores.

Você acha que o computador e a televisão se unirão em um aparelho, e em um meio?

A convergência dos meios já está acontecendo num grau tão maciço... Eu não assisto televisão. Eu leio jornais. Mas é porque um jornal físico cai na minha mão, ou porque está debaixo da minha porta. Não recebo nem faço ligações telefônicas. Não ouço rádio. Meu consumo de notícias é 95\% do laptop.

Você se comunica só por e-mail?

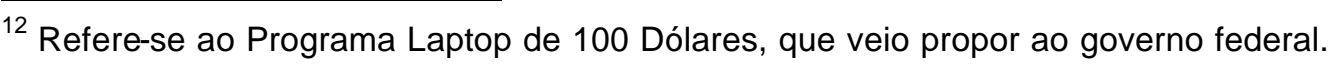


Sim.

Até com sua mulher?

Até com minha mulher ${ }^{13}$. Ela prefere. Estamos casados há quase 40 anos.

Quando dirige, você não ouve rádio?

Nunca dirijo. Estou sempre no banco de trás, digitando. Estou sempre em aviões, trens ou táxis.

Quando você diz que o jornal sobre papel será descontinuado rapidamente, com que prazo trabalha?

É mais de cinco anos, mas menos de dez para uma descontinuação abrangente. É um pouco como a câmera de filme. Sabíamos, 20 anos atrás, que o filme ia acabar. Vocês não usam mais câmeras de filme. O que não podíamos dizer era realmente quando isso aconteceria, de maneira que haveria câmeras digitais e computadores em número suficiente para que a imprensa os usasse. A mesma coisa acontecerá com o papel. Não para fazer anotações, nem mesmo para imprimir livros. Não quero dizer nesse sentido. Mas para jornais e revistas.

Em menos de dez anos, mais pessoas os estarão lendo em computadores do que no papel?

Poderá se parecer com papel e $æ$ sentir como se fosse papel. Mas é um pedaço de plástico que é um computador.

Mas uma parte da circulação do New York Times e do Washington Post ainda será distribuída em papel?

Veja bem. Nesta semana, o New York Times passou a ter mais leitores na internet do que no jornal físico. O jornal não será mais impresso. Ele será lido na tela. Você viu a nossa tela. ${ }^{14}$ É muito fácil, flexível, grande.

Muita gente acha que a tela de computador é muito brilhante e cansativa para ler, enquanto o papel é mais confortável..

\footnotetext{
${ }_{13}^{13}$ Elaine Negroponte, que dirige o programa no Camboja.

${ }^{14}$ Refere-se a um monitor de cristal líquido com conexão sem fio, chamado e-ink, desenvolvido pelo MIT, para a leitura de conteúdos que podem ser continuamente atualizados.
} 
Mas isso é porque ela emite luz. A tela do e-ink é reflexiva. Ela absorve luz, em vez de emitir. 